UNIVERSITE DU QUEBEC A CHICOUTIMI

\title{
PETROGRAPHY OF LEUCOCRATIC SEGREGATIONS IN THE MIGMATITIC \\ OLD GNEISS COMPLEX EAST OF CHICOUTIMI, QUEBEC
}

J. VICTOR OWEN

MODULE DES SCIENCES DE LA TERRE

MEMOIRE PRESENTE EN VUE DE L'OBTENTION

DU GRADE DE MAITRE EN SCIENCES APPLIQUEES

MARS, 1981 


\section{Bibliothèque}

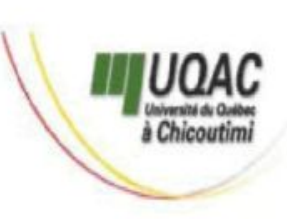

\section{Mise en garde/Advice}

Afin de rendre accessible au plus Motivated by a desire to make the grand nombre le résultat des results of its graduate students' travaux de recherche menés par ses research accessible to all, and in étudiants gradués et dans l'esprit des accordance with the rules règles qui régissent le dépôt et la governing the acceptation and diffusion des mémoires et thèses diffusion of dissertations and produits dans cette Institution, theses in this Institution, the I'Université du Québec à Université du Québec à Chicoutimi (UQAC) est fière de Chicoutimi (UQAC) is proud to rendre accessible une version make a complete version of this complète et gratuite de cette œuvre. work available at no cost to the reader.

L'auteur conserve néanmoins la The author retains ownership of the propriété du droit d'auteur qui copyright of this dissertation or protège ce mémoire ou cette thèse. thesis. Neither the dissertation or Ni le mémoire ou la thèse ni des thesis, nor substantial extracts from extraits substantiels de ceux-ci ne it, may be printed or otherwise peuvent être imprimés ou autrement reproduced without the author's reproduits sans son autorisation. permission. 
ABSTRACT

PETROGRAPHY OF LEUCOCRATIC SEGREGATIONS IN THE MIGMATITIC

OLD GNEISS COMPLEX EAST OF CHICOUTIMI, QUEBEC

Possible mechanisms and conditions of polyphase migmatization have been determined for quartzofeldspathic segregations in the migmatitic old Gneiss Complex east of Chicoutimi, Quebec. Rocks of three age groups have been identified:

1) Paragneisses, related concordant amphibolite, granite I, and rare amphibolite I dykes
outlining S1 schistosity.

2) Charnockitic granite IIa, granite IIb augengneiss, and rocks of age group I were intruded by four generations of felsic to mafic dykes emplaced in a regional-scale tensional environment. Subsequent compression (deformation IIa) formed a dominant S2a schistosity, which controls localization of leucocratic segregations generated early in during deformation IIb, subsequently refolded by deformation IIc, during which mobilizáte IIb veins segregated along F2c strain slip axial plane surfaces. Late leucosomes generated during migmatization II cross cut F2b folds, F2c axial planes, and earlier formed leucosomes. Leucosomes generated during migmatization $I$ and complex migmatization II are in situ: leucosome mineralogy is controlled by paleosome type and melanosomes consisting of paleosome mafic minerals are present. Migmatization I leucosomes consist of subanatectic mineral assemblages, and are considered to be products of metamorphic segregation tentatively under conditions of 650 to $700 \mathrm{C}$, at 3.5 to $4.5 \mathrm{~kb}$. Migmatization II leucosomes exhibit fluid behaviour, and leucosome plagioclases (An 12-15) are considerably more albitic than melanosome plagioclases (An 28) in granite I paleosomes, therefore an anatectic origin is indicated. The paragneiss mineral assemblage garnet-cordierite ( $\mathrm{Fe}: \mathrm{Mg} \sim 4: 6)$-potash feldspar, retrograding to biotite-sillimanite-quartz, indicates anatectic conditions of 750 to $800 \mathrm{C}$, at about $5.5 \mathrm{~kb}(15 \mathrm{to} 20 \mathrm{~km})$, given that $\mathrm{P}(\mathrm{H} 2 \mathrm{O})=(?) \mathrm{P}$ total. Dehydration reactions instigated partial melting in all. rocks except amphibolites, where migmatization occurred largely within the stability fields of biotite and hornblende (very locally breaks down to clinopyroxene + (?) melt). Amphibolites for the most part segregated mobilizate II leucosomes by the process of metamorphic segregation, whereas granitic rocks and paragneisses suffered partial melting during migmatization II.

3) Following deformation IIc trondhjemitic to granitic pegmatites and granitoids (mobilizate III) were injected into rocks of age groups I and II, and, west of the study area, syentitic granite III plutons Multiple pegmatite injection in part coincided with deformation III shearing; some pegmatites follow $S 3$ shear surfaces, subsequently reactivated, shearing the enclosed pegmatite vein. 
RESUME

\title{
PETROGRAPHIE DES SEGREGATIONS LEUCOCRATES DU COMPLEXE MIGMATITIQUE
}

\author{
A L'EST DE CHICOUTIMI, QUEBEC
}

\begin{abstract}
Les mécanismes et les conditions de migmatisation polyphasée ont été déterminés pour, les ségrégations quartzo-feldspathiques du complexe migmatitique 1 'est de Chicoutimi, Quebec. Chronologiquement, trois groupes lithostructuraux sont distingués:
\end{abstract}

1) Les paragneiss, les amphibolites concordantes associēes, le granite I et local ement des dykes d'amphibolite $I{ }^{\prime}$, Toutes ces roches contiennent des veines leucocrates minces (mobilisat $I$ ), qui suivent la schistosite $S 1$.

2) Un gneiss charnockitique (granite IIa) et le granite gneissique oeillé IIb. Toutes les roches des groupes I et II ont étè injectees par au moins 4 génèrations de dykes felșiques à mafiques. La mise en place de ces dykes coincide avec une periode d'extension régionale. Une compression subsequente (déformation IIa) a crēe une schistosité dominante (IIa) gui contrôle la localisation des segregations leucocrates (mobilisat IIa) generees tot pendant la migmatisation II. Ces mobilisats ont ete plisses (F2b) durant la dêformation IIb, et peu après replissês par la déformation IIc. Durant cette déformation, le mobilisat IIb s est accumule le long des surfaces de "strain slip" (S2c), parallêles aux plans axiaux des plis F2c. Les leucosomes générés pendant les stages tardifs de la migmatisation II recoupent les plis F2b, les plans axiaux de F2c et les leucosomes antérieurs.

Les leucosomes gēnerés pendant les périodes de migmatisation polyphasés I et II le furent in situ. La minéralogie des leucosomes est contrôlèe par le type de paleosome et les minêraux mafiques des mélanosomes presents sont les mêmes que ceux du paleosome correspondant. Les veines du mobilisat I. consistent en assemblages minēralogiques subanatectiques qui sont considerēs comme un des produits de sēgregation métamorphiques qui se sont formés sous des conditions estimées à $650-700 \mathrm{C} ; 3.5-4.5 \mathrm{~kb}$. Les leucosomes gênerês durant la migmatisation polyphasée II montrent des gomportements de fluide. Les plagjoclases dans le mélanosome (An 28) du granite I ad jacent. Ainsi, une origine anatectique est indiquee pour le mobilisat II. L assemblage mineralogique grenat-cordierite (Fe:Mg 4:6)-feldspath potassique, qui se transforme par retrogression en biotite-silimanite-quartz dans le paragneiss, indique des conditions d'anatexie $>750 \mathrm{C}$, a $5.5 \mathrm{~kb}(95-20 \mathrm{~km})$. Des reactions de déshydratation amorcent l anatexie dans toutes les roches sauf les amphibolites, ơ la migmatisation s est produite largement dans les champs de stabilité de la biotite et de la hornblende, ce deuxiẽme minéral se transforme localement en clinopyroxene + (?) liquide. La presence des veines de mobilisat II dans les amphibolites est dûe largement au processus de ségregation métamorphique. Par contre, les roches granitiques ainsi que les paragneisșes on subit une anatexie lors de la migmatization 1 .

3) La mise en place de pegmatites et de granitoides (mobilisat III) qui suivent la deformation. IIc. Ces roches de composition trondhjemitique à granitigue se-sont mis en place dans les roches du groupe I et II et à 1 ouest de la région étudiée, dans les plutons syénitiques (granite III) La mise en place polyphasee des pegmatites coincide en partie avec le cisaillement de la deformation III. Quelques pegmatites suivent les surfaces de cisaillement "S3" qui sont subsequemment reactivêes, cisaillant ainsi la pegmatite. 
DEDICATION

This study is respectfully dedicated to the memory of

Goronwy Owen, Welsh bard, who would have understood.

\section{Coffadwriaeth am y prydydd annwyl \\ Diweddar o"r Môn, Gwynedd}

Bu farw 1780 i mewn Brunswick Newydd

Er mwyn Cymru

"Ail i"r ar ael Eryri
Cyfartal hoewal a hi"
Cywydd y Farn 


\section{TABLE OF CONTENTS}

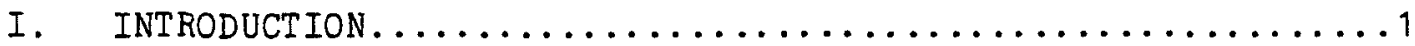

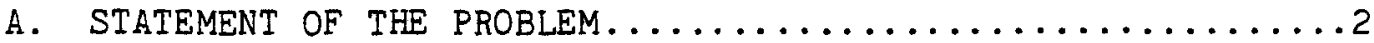

B. FIELD WORK AND SAMPLE COLLECTION...................

II. STRATIGRAPHY AND STRUCTURAL GEOLOGY OF THE STUDY AREA.....8

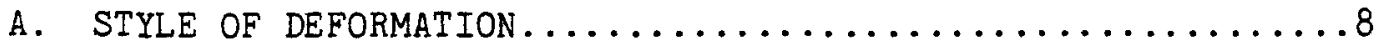

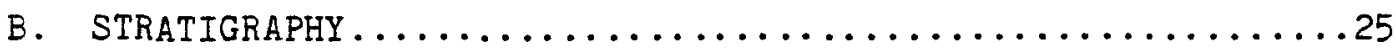

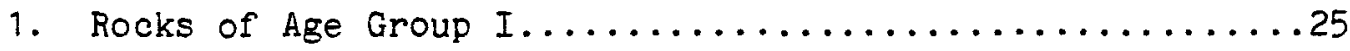

2. Rocks of Age Group II.............................

3. Rocks of Age Group III....................... 45

III. MIGMATITES............................... 48

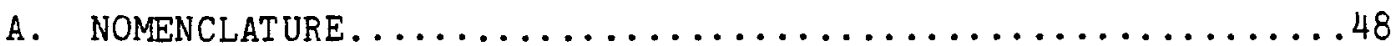

B. POSSIBLE ORIGINS OF MIGMATITES ................ 49

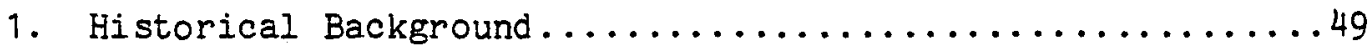

2. Mechanisms of Migmatization.................. 53

3. Possible Criteria for Distinguishing Migmatization

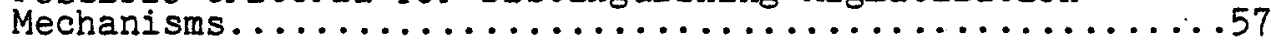

IV. MESOSCOPIC FEATURES AND PETROGRAPHY OF LEUCOCRATIC

SEGREGATIONS IN THE STUDY AREA................67

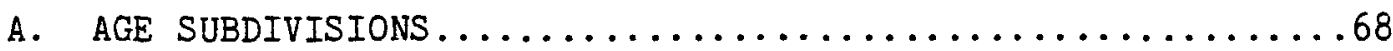

B. PETROGRAPHY OF THE MOBILIZATES ................

1. Mobilizate I:

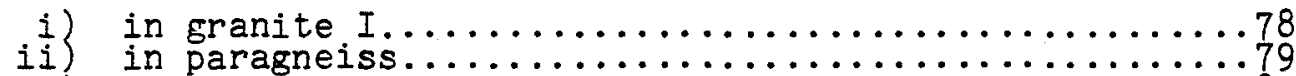

iii) in concordant amphibolite...................

2. Mobilizate IIa:

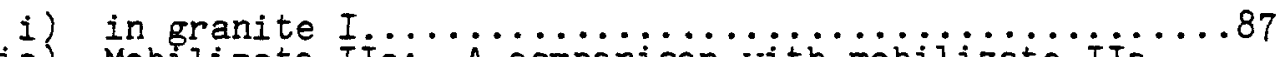

ia) Mobilizate IIc: A comparison with mobilizate ila

ii) in paragneiss... in granite I................90

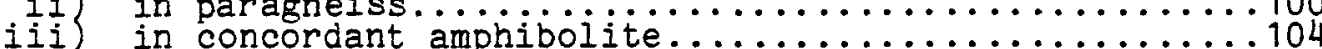

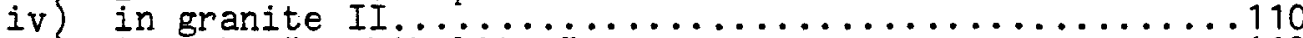

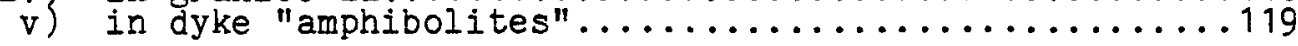

3. Mobilizate IIb.............................. 122

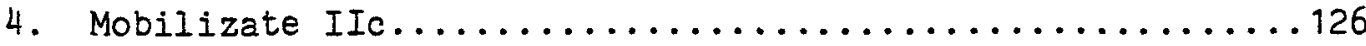

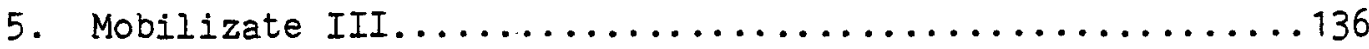

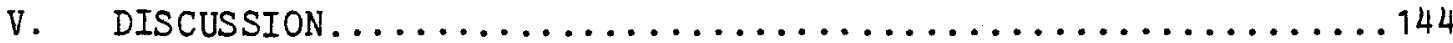

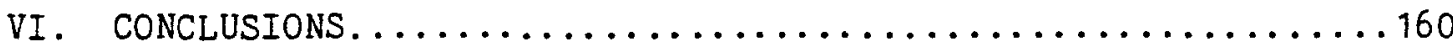




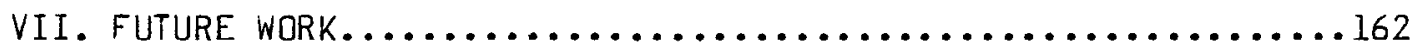

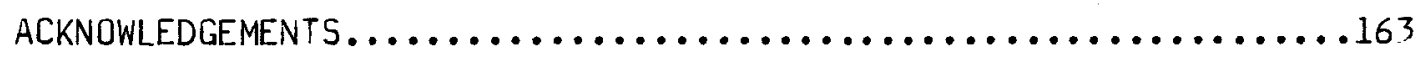

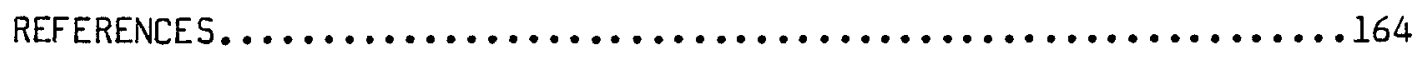

APPENDIX 1: Point count results............................

APPENDIX 2: Cross reference: Plates/File number..............171 


\section{FIGURES}

1. Regional geology.........................

2. Geology of the study area.................... 6

3. F2c refolding of $F 2 b$ folds in granite $I \ldots \ldots \ldots \ldots \ldots \ldots$

4. F2b folded dyke amphibolite IIb in granite I. . . . . . . 17

5. F2b folded dyke amphiblite IIb in charnockitic gneiss.... 19

6. Detached hinge of isoclinal F2b-folded dyke amphibolite...20

7. F2c refolding of $F 2 b$ folds in dyke amphibolite.........21

8. F2c refolding of F2a-folded mobilizate $I$ veins in

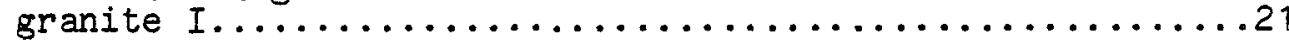

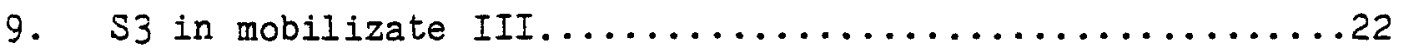

10. Saguenay graben-related mylonitization.............23

11. Boudinaged calcsilicate in concordant amphibolite.......27

12. Interbands of paragneiss in granite $1 \ldots \ldots \ldots \ldots \ldots \ldots \ldots$

13. Amphibolite I dykes in granite I inclusion in charnockitic gneiss..............................

14. Amphibolite I dyke in granite $I \ldots \ldots \ldots \ldots \ldots \ldots \ldots \ldots \ldots \ldots \ldots \ldots \ldots$

15. Amphibolite $I$ dyke in granite $I$, cut by dyke

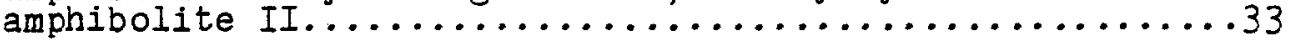

16. Discordant amphibolite IIb dykes in paragneiss..........39

17. Amphibolite IIa dykes cross-cut by dyke amphibolite IIb...39

18. Amphibolite IIc dyke cross-cutting concordant amphibolite IIb

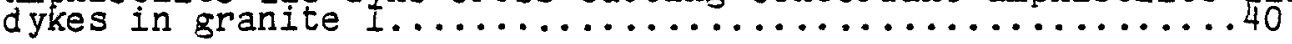

19. F2b folded granitic dykes of Age Group II in granite I. ...40

20. Discordant granitic dykes of Age Group II in paragneiss...41

21. Dyke amphibolite IIb cutting a granitic dyke in granite I..42

22. Discordant "granite III" in concordant amphibolite.......47

23. Morphology of the neosome component of a migmatitic

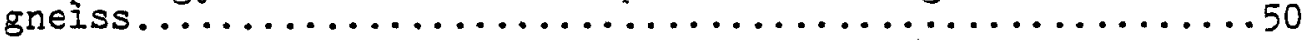

24. Mobilizate cross-cutting relationships in granite I......72

25. Mobilizate cross-cutting relationships in paragneiss......72

26. Mobilizate III cutting mobilizate II in granite IIb......73

27. Summary of occurrences of mobilizates..............

28. Mobilizate IIc in granite $I \ldots \ldots \ldots \ldots \ldots \ldots \ldots \ldots \ldots$

29. Thin section aspect of mobilizate IIa in granite I......98 
30. Mobilizate II "spider" morphology in concordant

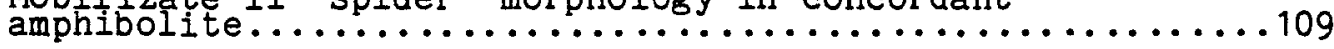

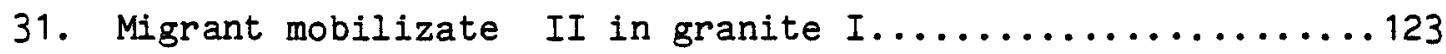

32. Migrant mobilizate II in pelitic paragneiss............ 123

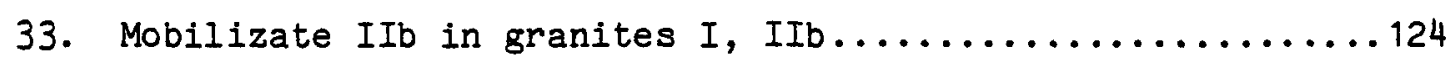

34. Discordant mobilizate III in granite I............. 138

35. Recrystallization of amphibolite inclusions in mobilizate III............................... 139

36. Sketch of thin sections of paleosome-restite from mobilizate II formation in arkosic quartzite............ 146

37. Quartz-plagioclase-K-feldspar ratios of mobilizates I, IIa from different paleosomes........................... 157

38. Proposed PT conditions of migmatization I, II in the

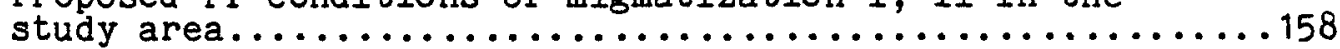

39. Optical estimate of the $\mathrm{Fe}$ content of cordierite from pelitic paragneiss in the study area................. 159 


\section{PLATES}

1. Evidence for polyphase migmatization in migmatitic pelitic paragneiss.........................

2. Refolded relicts of F2a folds in dyke amphibolite.......18

3. Late quartz filling breccia zone..................24

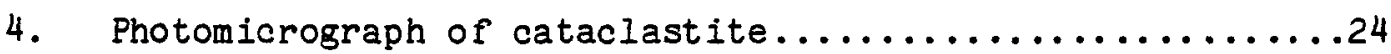

5. Orthopyroxene-rich mobilizate II in concordant

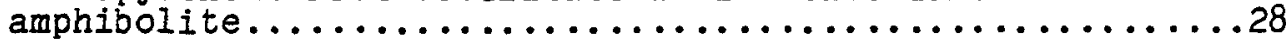

6. Folded calcsilicate layers in concordant amphibolite.....28

7. Photomicrograph of clinopyroxene in granite $1 \ldots \ldots \ldots \ldots .28$

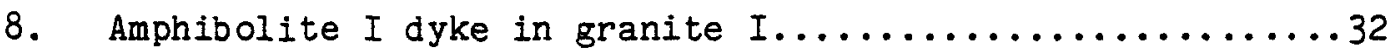

9. Concordant/discordant features of granite IIa...........35

10. Retrograde hornblende mantling orthopyroxene in

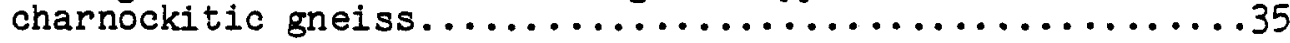

11. Features of dyke "amphibolites".................43

12. Dyke amphibolite IIb following a concordant granitic dyke of Age Group II..........................41

13. Cross-cutting mobilizate relations in granite I.......75

14. Mobilizate III cutting mobilizate II in granite IIb.....76

15. Photomicrographs of mobilizate $I$ in various paleosomes....81

16. Mobilizate $I$ in paragneiss and concordant amphibolite....83

17. Aspects of mobilizate II veins in granite I..........93

18. Mobilizate IIc in granite I...................95

19. Mobilizate IIa streaks in granite I..................

20. Mobilizate IIa filling interstices between dyke amphibolite

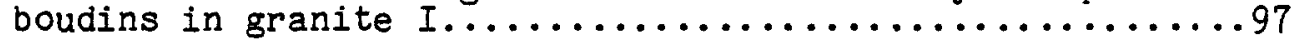

21. Photomicrograph of mobilizate IIa in granite I........99

22. Pinch and swell structure in mobilizate II veins in

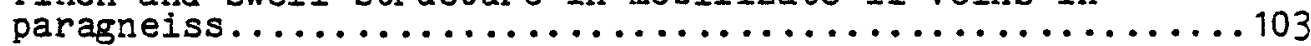

23. Photomicrographs of mobilizate II in paragneiss.........103

24. Aspects of mobilizate IIa in concordant amphibolite......107

25. Clinopyroxene in mobilizate II flecks in

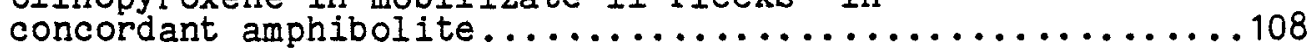

26. Photomicrographs of mobilizate IIa in concordant

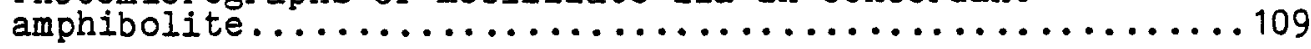

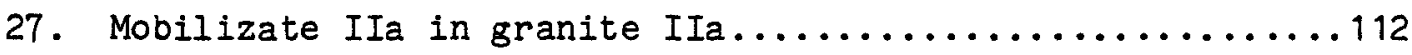

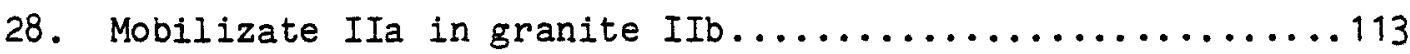


29. Photomicrograph of mobilizate IIa in granite IIb....... 112

30. Photomicrographs of clinopyroxene-bearing mobilizate II

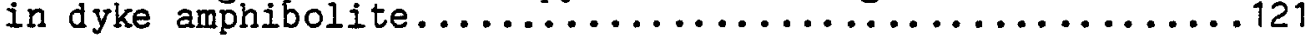

31. Mobilizate IIb in concordant amphibolite.............. 124

32. Aspects of mobilizate IIb in granite I................ 125

33. Photomicrographs of mobilizate IIc in granite I........128

34. Feldspar blastesis homogenizing dyke amphibolite in

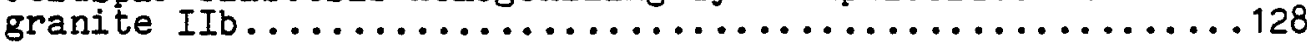

35. Discordant mobilizate III dyke in granite IIa......... 138

36. Trellis pattern (joints) outlined by mobilizate III in

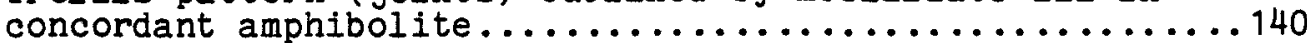

37. Inclusion of granite $I$ in mobilizate III............. 140

38. Recrystallization zone adjacent to mobilizate III in

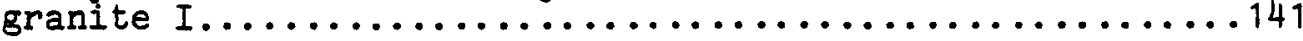

39. Photomicrographs of granitic/trondhjemitic

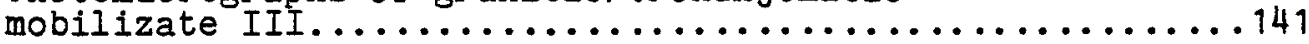

40. Mobilizate II segregation in arkosic quartzite..........146

41. Paragenesis garnet-cordierite- $\mathbb{K}$-spar retrograding to biotite-silimanite-quartz in pelitic paragneiss....... 155

42. Cross-cutting granitic pegmatite (mobilizate III) dykes...159 


\section{TABLES}

1. Stratigraphy of the Old Gneiss Complex................9

2. Criteria for distinguishing structural elements in

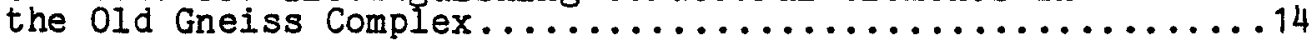

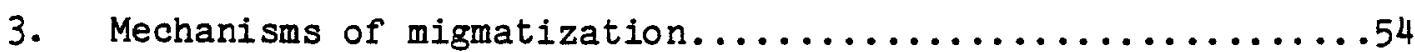

4. Flow chart for identifying possible mechanisms of

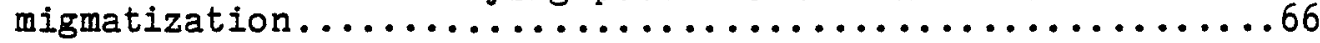

5. Mesoscopic criteria for distinguishing different generations of mobilizates..........................69

6. Mineralogical characteristics of mobilizate I-paleosome:

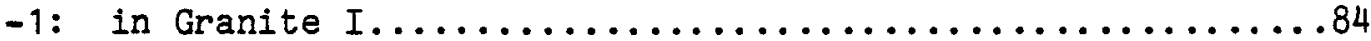

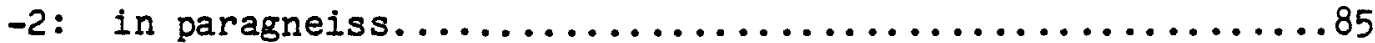

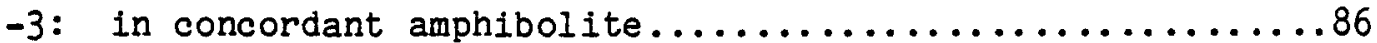

7a. Textures of granulite-grade gneisses.................101

7b. Paleosome and in situ mobilizate textures of the Old Gneiss Complex................................. 102

8. Mineralogical characteristics of mobilizate IIa-paleosome:

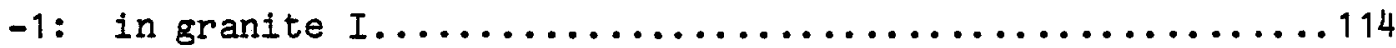

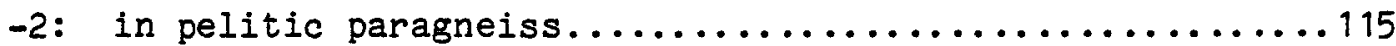

-3 : in concordant amphibolite....................116

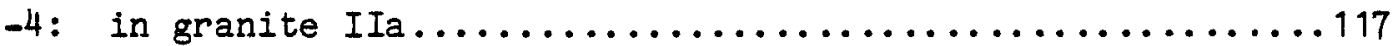

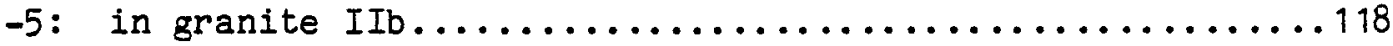

9. Mineralogical characteristics of mobilizate II in dyke amphibolite:

-1: in dyke amphibolite IIc...................... 129

$-2:$ in dyke amphibolite IIb...................... 130

$-3:$ in dyke amphibolite IIb...........................

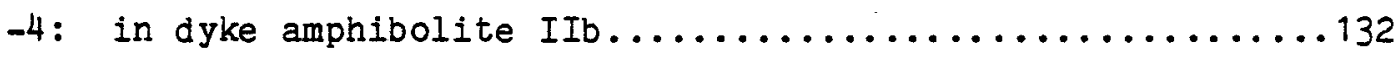

$-5:$ in dyke amphibolite IIb..................... 133

-6: where migrant leucosomes infiltrate dyke amphibolite.... 134

10. Mineralogical characteristics of mobilizate IIb-paleosome:

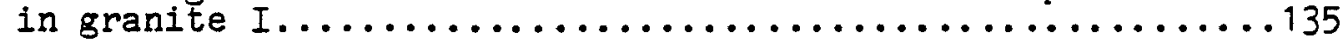

11. Mineralogical characteristics of mobilizate III......... 142

12. Composition of recrystallization zones in amphibolite inclusions in mobilizate III......................... 143 
I. INTRODUCTION

The migmatitic 01d Gneiss Complex contains cross-cutting leucocratic segregations indicative of polyphase migmatization (Owen et al, 1980). The study area, east of Chicoutimi, Quebec, lies within the Central Granulite Terrain (Wynne-Edwards, 1972) of the Grenville Province of the Canadian Precambrian Shield.

The region may be chronologically subdivided into 1) migmatitic supracrustal rocks and granitic gneisses; 2) massifs of the anorthosite-mangerite suite, and 3) late to post-kinematic calcalcaline plutons (Fig. 1) (Woussen et al, 1980; Dimroth et al, 1980). The present study area (Fig. 2) lies within part of unit 1, the migmatitic para- and orthogneisses of the so-called old Gneiss Complex, constituting the basement complex for unit 2 , subsequently intruded by unit 3 plutonites. Unit 1 is characterized by polyphase deformation, migmatization, and igneous activity. The paragneisses have been $\mathrm{Rb} / \mathrm{Sr}$ age dated at $-1482 \mathrm{m.y}$. (Frith and Doig, 1973), reinterpreted by Doig (personal communication, 1980) to represent a metamorphic updating of Aphebian ( $>1800$ m.y.) sediments. Dimroth et al (1980, Table 1) relate early deformational features and migmatization within this unit to the Hudsonian orogeny ( $1800 \mathrm{m.y.}$ ), therefore the sediments probably are pre-Hudsonian.

The geology of the Chicoutimi area is dominated by the Lac St. Jean anorthosite complex, covering an area of some $20,000 \mathrm{sq}$. $\mathrm{km}$. The regional structural influence of the massif on the host gneisses is as yet incompletely understood. However, certain deformational elements within the gneisses are spatially related to the anorthosite at present exposure levels, and the variability of the attitudes of other structural elements within the gneisses on a regional scale may be interpreted within the context of temporally staggered anorthosite plutonism (Dimroth et al, 1980). The presence of cumulus textures, and a parallelism of structural fabrics in the anorthosite and 
enveloping host gneisses lead woussen et al (1980) to ascribe a diapiric mode of emplacement for the anorthosite, after initial crystallization at a depth of some $25-30 \mathrm{~km}$. As such, structural patterns within the gneisses stradding the anorthosite may be expected to demonstrate further evidence of vertical tectonism, as previously described in other smaller anorthosite bodies within the Grenville Province (Martignole and Schrijver, 1970a,b) and in certain granitic plutons (Berger and Pitcher, 1970). Complex lobe geometry may complicate structural patterns.

Emplacement of the anorthosite complex postdated the Hudsonian Orogeny, probably occurring between the latter and the Grenville Orogeny (ca. $1050 \mathrm{~m} . \mathrm{y}$. ). The anorthosite itself, owing to its composition, may not be directly age dated by isotopic means. However, a syenite-one of a series of late felsic intrusives cutting the anorthosite complex-has been $\mathrm{K} / \mathrm{Ar}$ age dated at $\sim 896-937 \mathrm{~m} . \mathrm{y}$. (Doig and Barton, 1968), placing a minimum age on the final emplacement of the complex. $\mathrm{Rb} / \mathrm{Sr}$ age dating of the mangerites cutting the anorthosites vary from 1,000 to $1,700 \mathrm{~m} . \mathrm{y}$. , rendering their interpretation hazardous (Frith and Doig, 1973).

The post Grenville Saguenay graben was the last major tectonic event in the region. Associated with the graben is alkaline magmatism, including Nb-bearing carbonatite (St. Honore) with an associated alkaline igneous ring complex and lamprophyre dykes (Gagnon, 1979). After partial karstification of the carbonatite, the area was blanketed with Cambro-Ordovician limestones and shales, since largely eroded by Quaternary glaciation.

\section{A. STATEMENT OF THE PROBLEM}

Stratigraphic and structural aspects of the migmatitic gneisses constituting the old Gneiss Complex have not previously been described. Given evidence of several generations of mobilizates in 
these gneisses, the fundamental problem considered by this study concerns the conditions and mechanisms of polyphase migmatization of early Grenville Province gneisses in the Chicoutimi area. The significance of polyphase migmatization becomes apparent only after cross-cutting mobilizate segregations are categorized in a stratigraphic and structural framework. Mechanisms and conditions of migmatization are indicated by the morphologies and mineral parageneses constituting each generation of mobilizate. Systematic documentation of these various features yields estimates of the upper limits of PT conditions related to polyphase migmatization. Within a stratigraphic and structural context, the method broadly indicates the metamorphic and tectonic evolution of early Grenville supracrustal and plutonic rocks.

As a basis for this interpretation, detailed field mapping established the chronology of these segregations and the structural controls of their localization. Petrographic techniques, in particular modal analysis, provided quantitative compositional data, which, coupled with field data, indicate possible migmatization mechanisms responsible for the different generations of mobilizates.

B. FIELD WORK AND SAMPLE COLLECTION

Field work was largely conducted along the shoreline of the Saguenay river at St. Fulgence, and adjacent to Rang St. Martin (Fig. 2). Since the foliation in the rocks is at a high angle to the shoreline, a cross section was thereby established. For comparative purposes, some field work was conducted at Cap Jaseux and at Ha ! Ha! Bay.

Section $O N$ at St. Fulgence (Fig. 2) is one kilometre long; section $O S$ along the Rang St. Martin shoreline is $3.1 \mathrm{~km}$ long. Each 
section is divided into $100 \mathrm{~m}$ wide divisions, consecutively numbered from west to east. Samples and detailed maps are numbered according to their location along the shoreline, and with respect to the number of samples taken, and maps drawn, within that division. Samples whose location is noted on a detailed map are denoted by an "F" suffix, corresponding to that identifying the map.

Large samples were taken to provide sufficient material for chemical analyses, performed by $M$. Hervet and $M$. Tremblay under the supervision of E. Dimroth and G. Woussen. Petrographic work was performed on the same individual leucocratic segregations and host rocks as were analysed.

Field relations were documented by photographs and detailed maps and sketches. The scale of mapping generally ranged from 1:10 to $1: 100$, depending upon the feature being documented. A generalized field map, which should serve to locate typical exposures of the different stratigraphic units, is presented as Fig. 2; a copy of the original 1:10,000 map is provided at the end of the present work." 


\section{FIGUKE 1.}

Regional geology of the Saguenay-Lac St. Jean area. Fror Dimroth et al, 1900. Craughting by A. wawrzkow.

\section{FIGURE 2.}

Simplified geology of the Old Gneiss Complex, as exposed within the study area. Refer to Table 2 and text for description of structural/stratigraphic relations. Note that franite III within the study area consists of unfoliated franitoics, probably related to polyphase mobilizate II pematite/granitoid injection, and can not be correlated witn syenitic granite III (Noussen et al, 1900 ; Dirrotn et al, 1900) olutons outcroppine near Chicoutimi. A copy of tne orizinal 1:10,000 map, of which the present fizure is a reduction, is provided at the end of the report. 
LEGEND

Palaeozoic

礛

Ordovicien timestone

:0. Cambro-Ordovician sediments

PreCambrian

Late graniles

1 Troctolite dyke

Diorite dyke

$\because$ Mangerite-monzonite

Anorthosite

$\because \quad$ Extont of amphibolite III dykes as presently known

\/ $\begin{aligned} & \text { Extent of amphibolite " } \\ & \text { dykes as presently know }\end{aligned}$

?

Undifferentiated gneiss (mainly granitic)

Paragneiss

FIGURE 1.

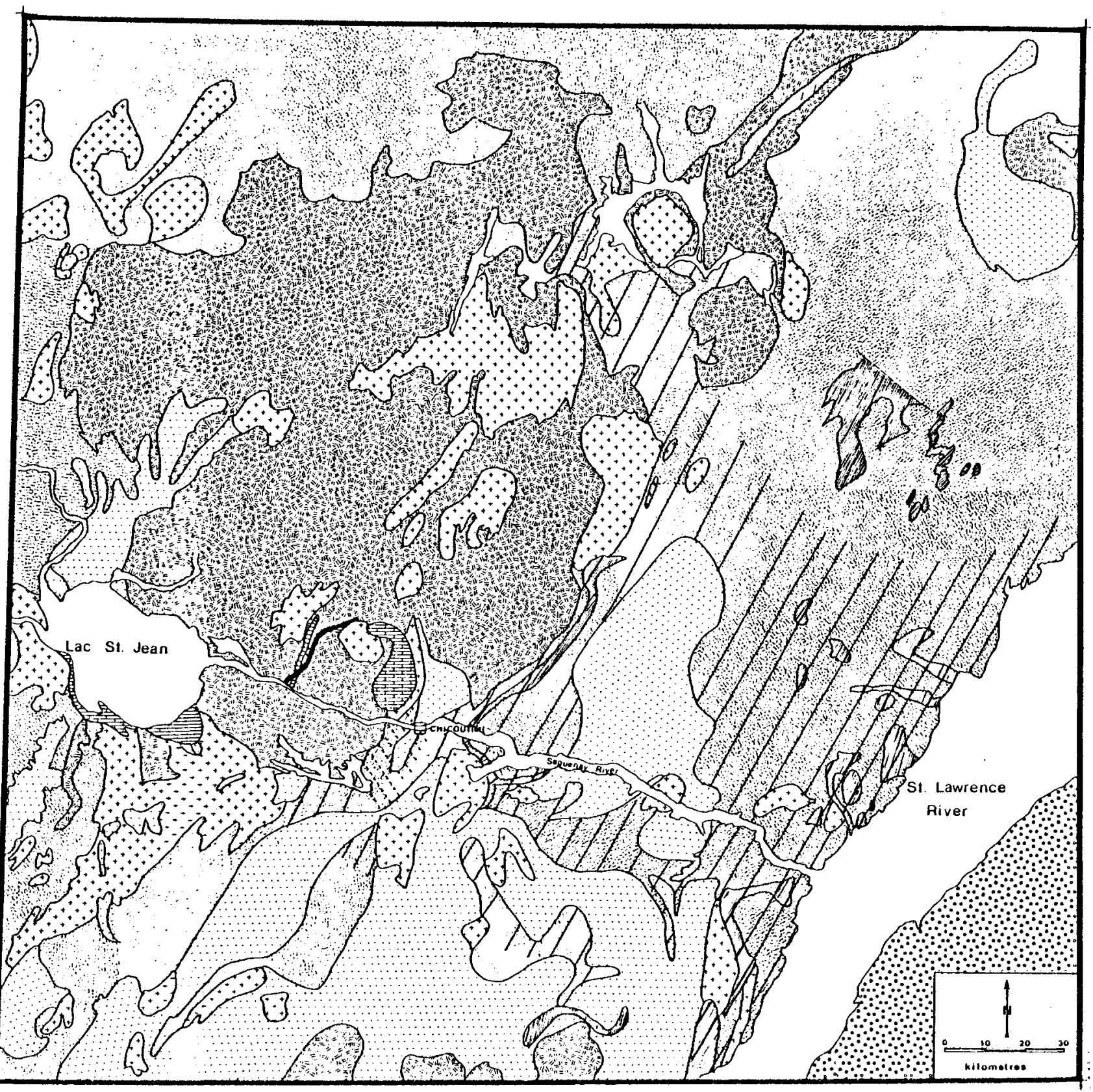




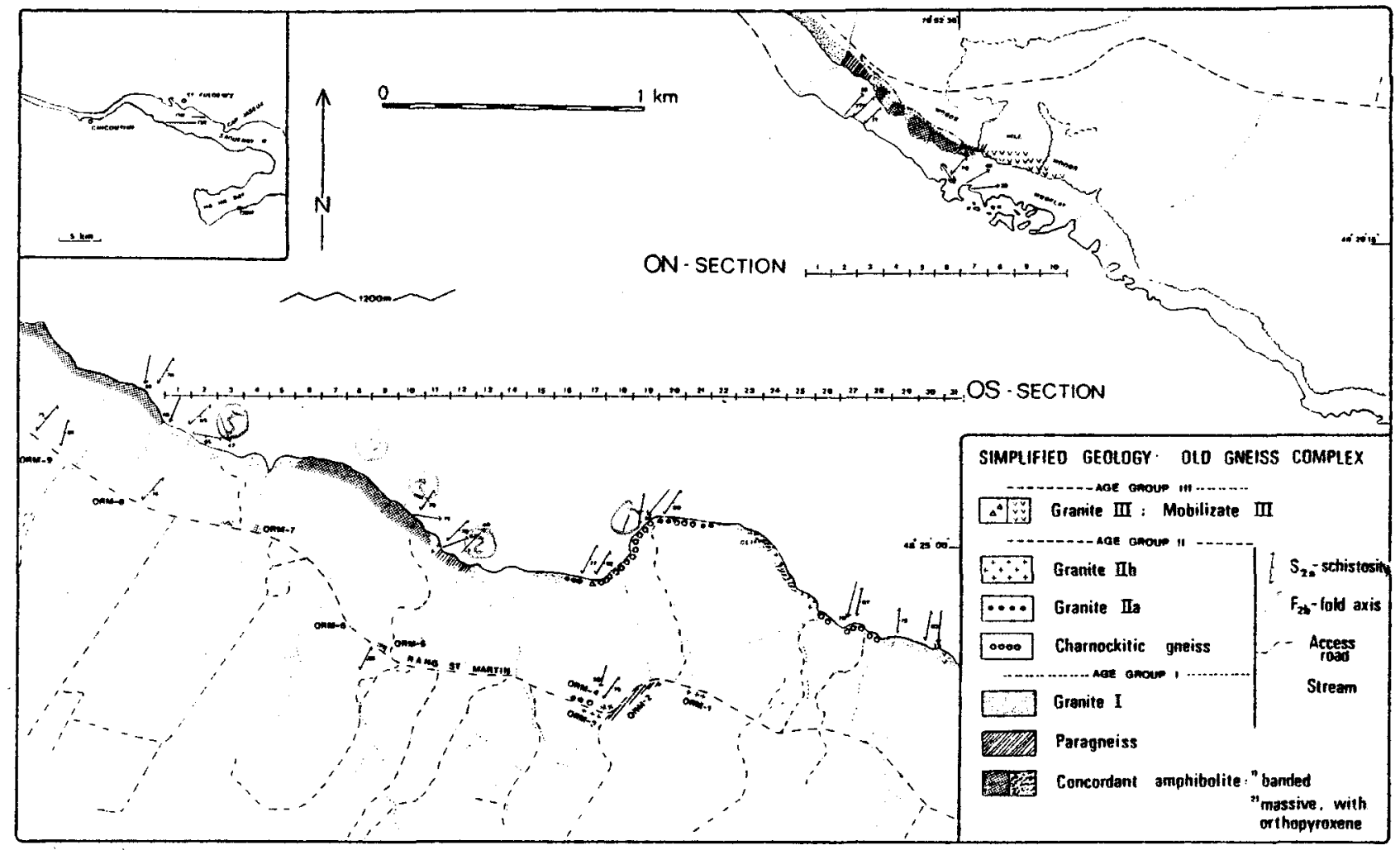

FIGURE 2 . 


\section{PLATE 1.}

Evidence for polyphase migmatization in migmatitic pelitic paragneiss from the old Gneiss Complex. A fine Erained, tizhtly folded leucocratic segregation (mobilizate I) is cross-cut by a coarser grained segresation (movilizate II). These cross-cutting relationships provide a basis for chronoloeic classification of mobilizate generation. Definition of the petromaonic characteristics of each mobilizate, and the relationship of mobilizate localization to palevscme structural features, allow consistent recognition of different Eenerations of leucceratic segregations in the migmatites e ist of Chicoutimi. The sample is sketched and described in detail in Fig 25. 


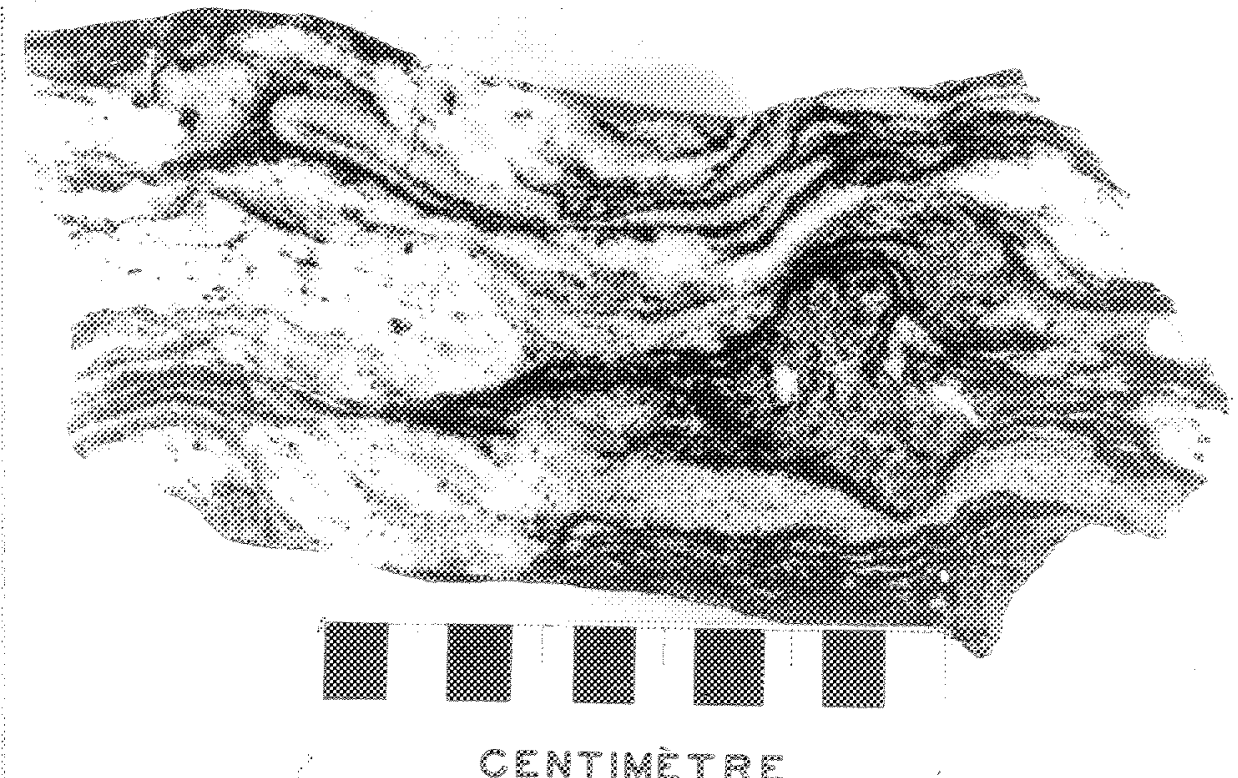

CENTMETRE

PLATE 1. 
I1. SIRATGKAHY AND STKUCTURAL GEOLOGY OF THE STUUY AKEA

The stratigraphy of the study area is presented in Iable 1. stratigraphic units are defined chronologically by their relation to three postulated episodes of deformation and migmatization, and by intrusive cross-cutting relationships. Cross-cutting relationships permit chronological classification of different generations of leveocratic segregations (products of polyphase migmatization); the relations of these to tectonic structures permit evaluation of the relative age of migmatization to each particular phase of deformation.

For convenience, rock units outcropping in the study area are suvdivided into three age groups, each subdivision being separated by a migmatization and/or deformational episode (Table 1).

\section{A. SIYLE OF LEEORMATION}

Before describing the petrography and field aspects of the diflerent stratigraphic units, it is opportune to describe the structural elements snown by rocks of different age groups. Folding patterns are best displayed by dyke amphibolites, and by neterogeneities, in particular products of migmatization, seen in otherwise homogeneous host rocks. Different products of migmatization will be referred to in establishing the forthcoming structural schema; their detailed description will be presented in section IV.

neferring to Table 2, all rocks of age group I are seen to contain mobilizate I leucocratic veins, outilning $S 1$. These veins are thrown into isoclinal folds ( $F Z a$ ) having $S 2 a$ as axial plane. No relicts of Fl folds having $S 1$ as axial plane have been recognized, due to strong structural overprinting during deformation DIla. Figure 3 (inset) snows mooilizate I veins thrown into small-scale isoclinal f2a folds 
$(-\cdots)$ : read "producing")

Saguenay graben faulting, mylonitization, and related events.

- - - - - - - - - -

Deformation 111 -..- $S_{3}$ shearing

-.............

Mobilizate 111 pegmatites: pre/syn deformation 111

Granite $\mid 11$

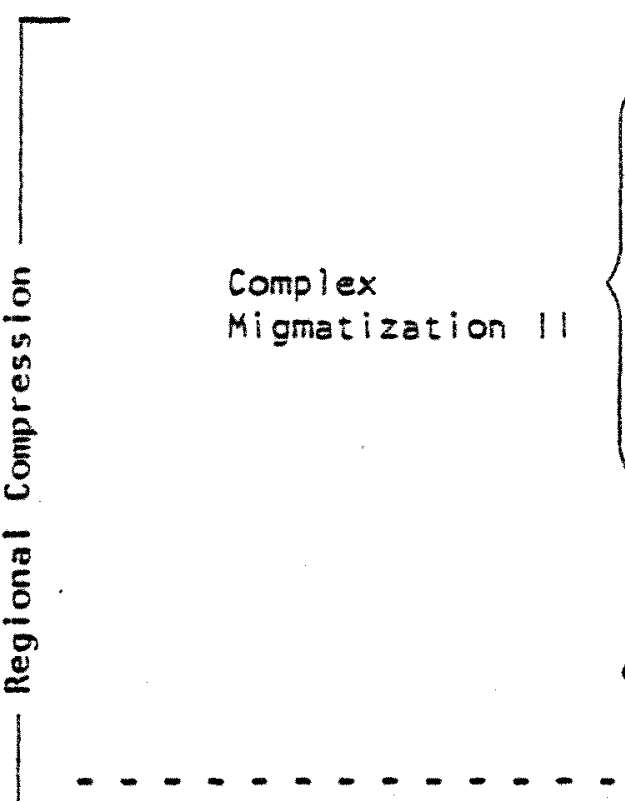

Mobilizate llc: coarse grained discordant pods

Mobilizate llb: syn-deformation lle (-----> $S_{2 C}-$

strain slip cleavage surfaces,

axial planar to $F_{2 c}$ )

Deformation $\mid 1 b-.-->F_{2 b}$ folding; no axial plane schistosity

Mobilizate lla: pre/syn-deformation llb. Sza controls leucosome localization.

Deformation lla: -.-- $S_{2 a}$ (axial plane schistosity to $F_{2 a}$ folds)

Granite $11 \mathrm{~b}$

Granite lla

Charnockitic gneiss

- - . - . . . . . - .

Deformation 1 -..- $S_{1}$

Migmatization 1: mobilizate 1 veins define $S_{1}$ surface

- - . . . . . . - .

Dyke amphibolite 1

Granite I

Paragneiss, concorónt amphibolite, cale-silicate 
in granite 1 , ano the eflects on these of subsequent folding episodes and modilizate generation. With the exception of compositional Danding (beding $=$ So) in the pelitic paragneiss, the s1 surface deineated by mooilizate I veins is the oldest foliation identifled in the uld Gneiss Complex.

following deformation I, rocks of age group I were intruded by large volumes of granitic rocks, constituting granite II. A period of regional extension followed, and is marked by the intrusion of large volumes of amphibolite Il dykes, which outcrop from west of the study area to the St. Lawrence river, a distance of some $150 \mathrm{~km}$. The majority of amphibolite Il dykes are concordant to the dominant foliation (SZa) in their host rocks. This foliation is also present in the amphipolite dykes, indicating that sza-formation postdates dyke injection. Sza presumably formed during a period of regional compression, representing a closing of the tensional environment operative during dyke injection. As such, the formation of the regional sca-foliation in rocks of age groups $I$ and $I I$ marks the initial effects of the complex defornation II (Table 1). Saa formed during deformation IIa and folds related to this deformation are termed rca-folds. These folds are probably represented by local internal folding seen in some amphibolite Il dykes, which have since been refolded (Plate 1). These rza-folds formed in some dykes during slippage along dyke-host rock interfaces during S2a development. The sca-schistosity is seen axial planar only to these internal folds, to some Fza-folded discordant dykes (Plate 1lf; Fig. 16) and to tightly foided modilizate I veins (Fig. 3).

Higmatization lla postdated fla-folding, with mobilizate lia veins being preferentially localized in flexural openings of the S2a-schistosity (Fig.3) These veins and their host rocks have been subsequentily folded. Inis deformation (IID) is responsible for most decimetre to metre scale folds in the study area. Fzo-folds (Fig. 4) 
have a neight/width ratio (hansen, 1971) of about 0.5 to 5.0 . No axial plane schistosity to f2o folds has been identified in the study arta, ano layering (ef. dykes) incicate folos, but doesn't actively control the folding mechanism. Thus, flo folds are not flexural shear folus, as are fza-folds, but are passive flow folds (Donath and Farker, 19o4). Fco-related drag folds commonly developed within folded amphidolite 11 dykes, refolding raa-fold folds (Plate 2 ). Amphibolite dykes in the study area show evidence of having been ductile during deformation. Individual dykes vary widely in thickness over short distances with 1 m thick dykes commoniy being 'smeared out' by foloing (kigs. 5, 0 ). Lespite this, individual folded dykes may be Lollowed for some distance, thereby outlining folding patterns in some detail (Fig. 4). Ine amplitude of F2b-folds ranges from about $10 \mathrm{~cm}$ to over $5 \mathrm{~m}$, perhaps averaging between 50 and $200 \mathrm{~cm}$. At $0 S-30$ (Fig. c) amphibolite II dykes about $10 \mathrm{~cm}$ thick are separated by similar thicknesses of host granite I, giving the unit a regularly banded appearance. This banding is not, nowever, due to a particularly close spacing of injected oykes, rather, it represents isoclinal folding of an extreme nature, wherein the noses of many folded dykes have been detached. In some cases, however the complete isoclinal fold may be followed, as seen in Fig. $O$. Axial planes of Feb-folds are steeply dipping, typically trending $145 \mathrm{E}$, more northerly in the eastern part of the US-section (Fig. 6), axes plunging moderately to the WE or SSW (tig. 2).

Locally, fab-folds are refolded. These folds are termed F2c, and have a weak axial plane schistosity Szc. This schistosity parallels strain slip cleavage surfaces along which mobilizate IIb has segregated (Figs. $3,7,0,20$ )., indicating that deformation $11 \mathrm{c}$ is synchronous with migmatization IIb. As such, these strain slip cleavage surfaces, where present, may serve to distinguish F2c-folds from F2D-folds, which lack an axial plane schistosity (Fig. 8 ). rec-folds are of a small scale, with wavelengths and amplitudes typically less than $50 \mathrm{~cm}$. In the study area, S20 strain slip 
cleavage surfaces trend from N10E to N60E, however, within a given outcrop where these surfaces are abundantly developed (ex. 0S-3,4), their attitude rarely varies more than ten degrees. F2c-refolding of F2b-folds may be related to anorthosite and mangerite (Fig. 1) diapirism, representing a regionally heterogeneous vertical tectonism, explaining the variability of orientation of the refolding in the general region (Dimroth et al, 1980).

Following the termination of complex deformation II, rocks of age group III were emplaced. These granite III and dyke amphibolite III. In the present study area, no amphibolite III dykes outcrop, and the unit described as granite III may not be correlated with the syenitic granite III intrusions near Chicoutimi (Dimroth et al, 1980). Rather, the "granite III" described in Table 1 and located in Fig. 2 includes quartz-rich, non-foliated biotite granites, likely related to multiple pegmatitic mobilizate III injection, constituting the "migmatization III" event (Table 1). Migmatization III is in part synchronous with deformation III. Excluding Saguenay graben-related shearing (see below), any internal shear fabric seen in mobilizate III pegmatites and their host rocks in the study area is a product of deformation III. Deformation III is represented by a shear cleavage, termed $S 3$, which typically deforms the regional schistosity $S 2 a$ in rocks of age groups I and II. Figures 9 and 26 show mobilizate III pegmatites with $S 3$ shear cleavage. Effects of deformation III are seen only locally within the study area. These effects increase in intensity and in frequency toward the Lac. St. Jean anorthosite some $15 \mathrm{~km}$ northwest of the study area, indicating that deformation III is related to the emplacement of this massif (Fig. 1).

Deformation III shearing may be distinguished from Saguenay graben-related structures insofar as the latter invariably are represented by small scale brecciated fault zones infiltrated by secondary pore space material, chiefly carbonates, crystalline quartz (Plate 3), and hematite. Here and there, cm-thick graben-related 
mylonite bands are seen (tig. 10, Hate 4). Saguenay graben-related structures are the last structural elements seen in the region, and are of negligible importance in the study area.

Criteria useful in distinguishing different generations of structural elements are presented in Table 2. 
TABLE 2: CRITERIA FOR DISTINGUISHING DIFFERENT GENERATIONS OF STRUCTURAL ELEMENTS IN THE OLD GNEISS COMPLEX

Elements related to Deformation III

S3: Shear cleavage developing within, and partly granulating, mobilizate III pegmatites, which often in part are concomitant with deformation III (S3 is often seen only in the pegmatite, indicating that the pegmatite filled an $S 3$ shear zone, crystallized, and suffered partial shearing due to reactivated $S 3$ movement)

\section{Elements related to Deformation IIc}

F2c: Small-scale ( $\mathrm{cm}$ to decimetre) refolding of F2b folds. Have S2c as axial plane, which hosts mobilizate IIb. S2c surfaces are often closely spaced (usually 15 to $50 \mathrm{~cm}$ ), as a result of the small scale of F2c folds. S2c is a shear cleavage: mobilizate IIb veins are partly granulated, quartz forms strained plates, and mafic clots are similarly oriented, paralleling the $52 c$ surface.

\section{Elements related to Deformation Ifb}

F2b: Intermediate-scale (am to $\mathrm{m}$ ), tight to isoclinal folds, predominant in the study area. Fold geometry is outlined but not controlled by heterogeneities (ex. dykes). This, and the absence of an axial plane schistosity, identifies the folding mechanism as passive flow. Migmatization IIa preceeds and overlaps deformation IIb, as evidenced by the localization of mobilizate IIa in DIIb-related flexural zones, seen deforming $S 2 a$, and the subsequent $F 2 b$ folding of these mobilizate IIa veins. 


\section{Elements related to Deformation IIa}

F2a: Small (cm) to intermediate (m) scale folding of dyke amphibolites and host rocks, with $\mathrm{S2a}$ (dominant schistosity) as axial plane. Mobilizate IIa veins are localized along S2a, accumulating in flexural openings of $\mathrm{S} 2 \mathrm{a}$ produced during DIIb. Amphibolite II dykes at a high angle to S2a may outline Fza-folds, and have a biotite-amphibole axial plane schistosity paralleling $\mathrm{S} 2 \mathrm{a}$. Dykes concordant to $\mathrm{S} 2 \mathrm{a}$ in the host rocks also contain $\mathrm{S} 2 \mathrm{a}$, and have been boudinaged by this same deformation (DIIa), here and there containing small scale internal folds due to slippage along the dyke-host rock interface. Mobilizate IIa material accumulates in DIIa-related interboudin zones, indicating that migmatization II commenced during DIIa. F2a-folds are controlled by rock layering. This fact, along with the presence of axial plane schistosity indicating shear or slip, identifies the folding mechanism as flexural slip.

Elements related to Deformation I

S1: Relicts of $F 1$ folds have not been identified in the 01d Gneiss Complex. Mobilizate I veins outline $S 1$ schistosity, formed during deformation $I$. The tight small-scale $(10 \mathrm{~cm})$ folds shown by some mobilizate $I$ veins has $S 2 a$ as axial plane, thus these folds are termed F2a.

Note: attitudes of structural elements are too variable within the study area to be of consistent use in distinguishing different generations of deformation and folding. Rather, folding episodes should be distinguished using the criterion of the presence/absence of an axial plane schistosity, and the control structural elements have on the localization of different generations of mobilizates (c.f. Table 3 for criteria useful in distinguishing leucosomes). 


\section{FIGURE 3 .}

F2c-refolding of F2b-folded S2a-schistosity, outlined by mobilizate IIa veins and by the strong biotite follation, in granite I. Slip-cleavage surfaces (S2C) bearing mobilizate IIb leucosomes are axial planar to the F2c folds. Inset at "A" shows an F2a-folded mobilizate I vein, pale grey in colour, and highly granulated, which paraliels the Sza biotite foliation in the granite I paleosome, along with which the vein was folded by F2b and subsequent folding episodes. Note the absence of possible F2a folds; these are folds formed during S2a-formation, with S2a as axial plane. F2b folds have no axial plane schistosity. 


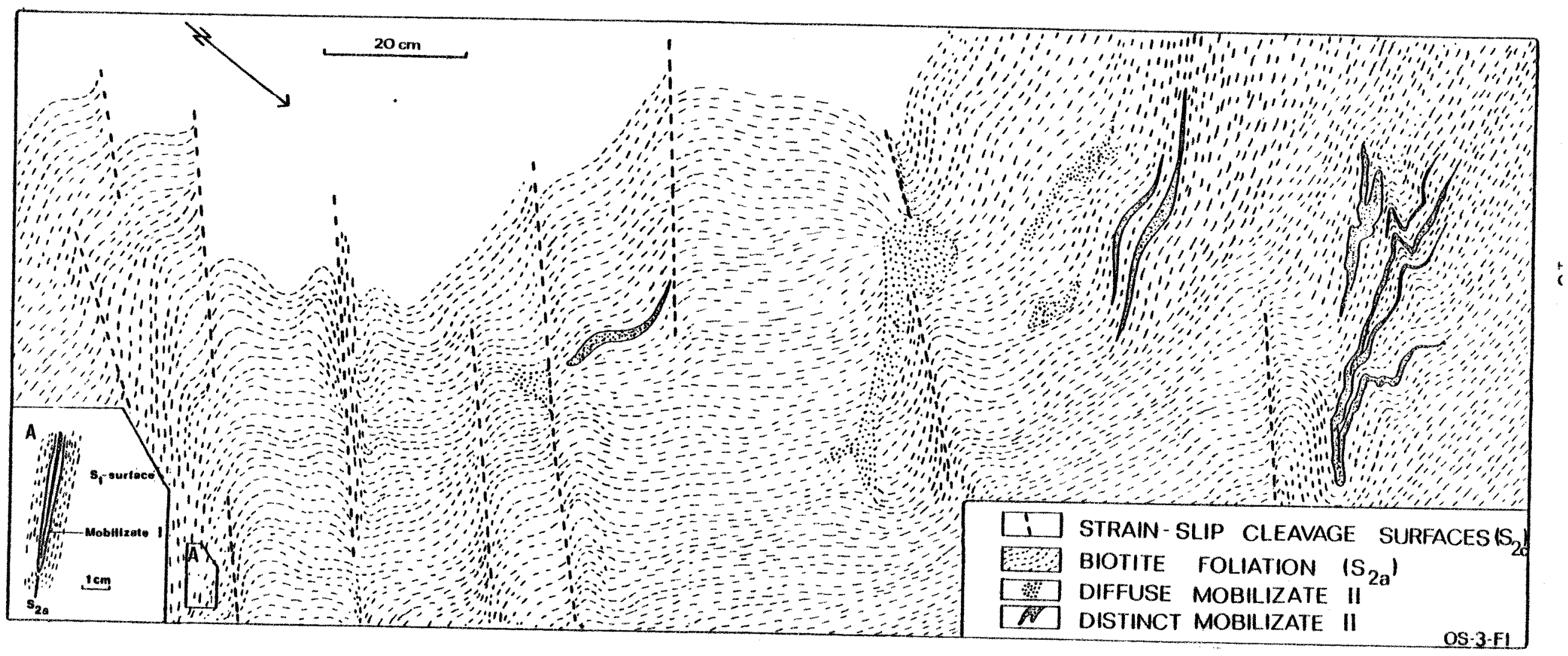

FIGURE 3.

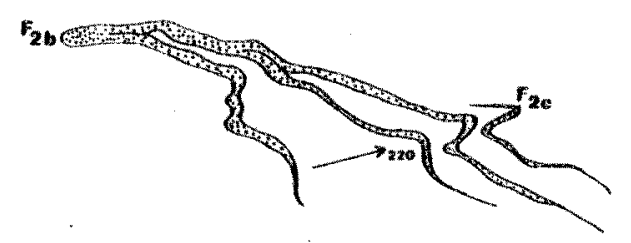


FIGURE 4.

F2b-folding of amphibolite II dykes, concordant to the dominant S2a biotite foliation in the granite I host rock.

PLATE 2.

Possible relicts of F2a folds, refolded by F2b, within a concordant amphibolite IIb dyke. Relict F2a folds are here represented by small scale asymmetrical folds outlined by the thin leucocratic "vein", top centre of photo, on the left limb of the F2b fold (axial plane parallels long direction of photo). These smali scale folds are asymmetric with respect to the larger scale $F 2 b$ folds, suggesting that these are earlier folds, ie F2a. In this case, the F2a folds are internal drag folds within the amphibolite II dyke. Photograph taken within $2 \mathrm{~m}$ of the nose of the $F 2 b$ folded dyke. Host rock of the dyke is granite IIa the source of much of the leucocratic material (mobilizate II) within the dyke. F2a folding is also seen in some discordant amphibolite II dykes which have S2a as axial plane (Fig. 18; Plate 11f). The same deformation, while folding discordant dykes, has boudinaged concordant dykes' (Figs. 17, 18). Location: OS-20. 


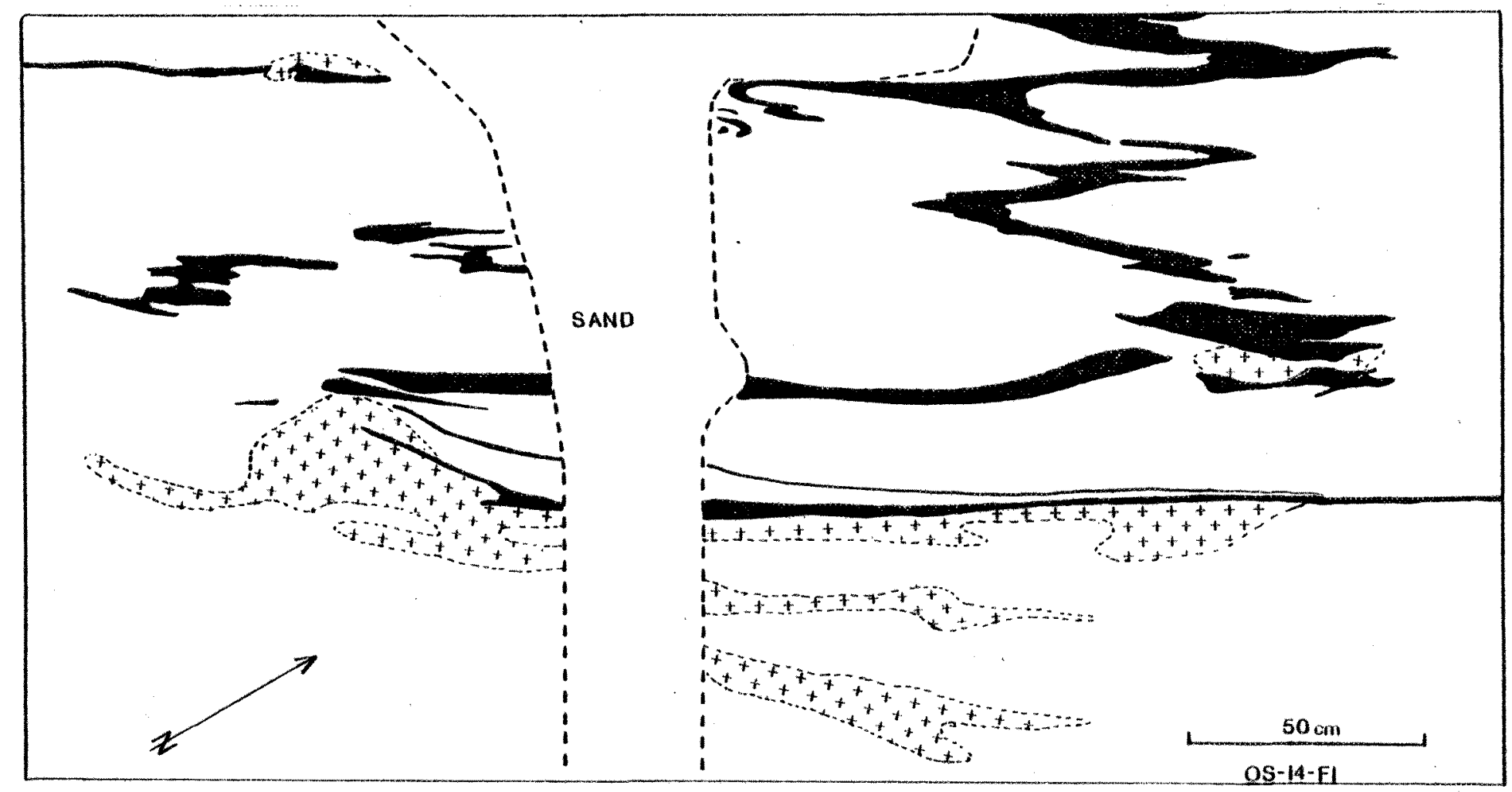

PIGURE 4.

DYKE AMPHBOLITE $\|\left[\begin{array}{l}+++ \\ ++ \\ ++\end{array}\right]$ MOBILIZATE $\|$

GRANITE I 


\section{FIGURE 5.}

"Smearing out" of amphibolite IIb dykes in streaky-textured charnockitic granite IIa, especially pronounced near the hinges of F2b-folds. Note the mobilizate II vein cutting the dyke.

\section{FIGURE 6.}

F2b isoclinal folding of a concordant amphibolite IIb dyke. Although paralleling the dominant biotite-(hornblende) S2a foliation th the granite I host, this type of folding is rarely visible in the absence of dyke amphibolite (or in situ mobilizate) markers.

FIGURE 7.

F2b isoclinally folded amphibolite IIb dyke, refolded about a N35E-trending axis by F2c, paralleling strain slip cleavage surfaces (S2c) along which mobilizate IIb has segregated. At upper right is the continuation of a N135E-trending Saguenay graben-related fault, which truncates the dyke (out of figure).

\section{FIGURE 8.}

F2c refolding of F2a folded mobilizate $I$ veins, in granite $I$. Sample OS-3-6.

a.) Symbols: dashing=biotite foliation (S2a); fine stippling=mobilizate I (grey, fine grained); black dots=mobilizate Ila (pink, medium grained); white=diffuse band of mobilizate IIb. At right is a late quartz stringer cutting mobilizate IIb.

b.) Explanation: folding of S2a schistosity axial planar to fiattened F2a folds, by F2c. Evidence: refolding has an axial planar schistosity (SZC) along which mobilizate IIb accumulated. Therefore the folding is not $F 2 b$, which is pervasive elsewhere in the outcrop, but which cannot be expressedly identified in the sample. 


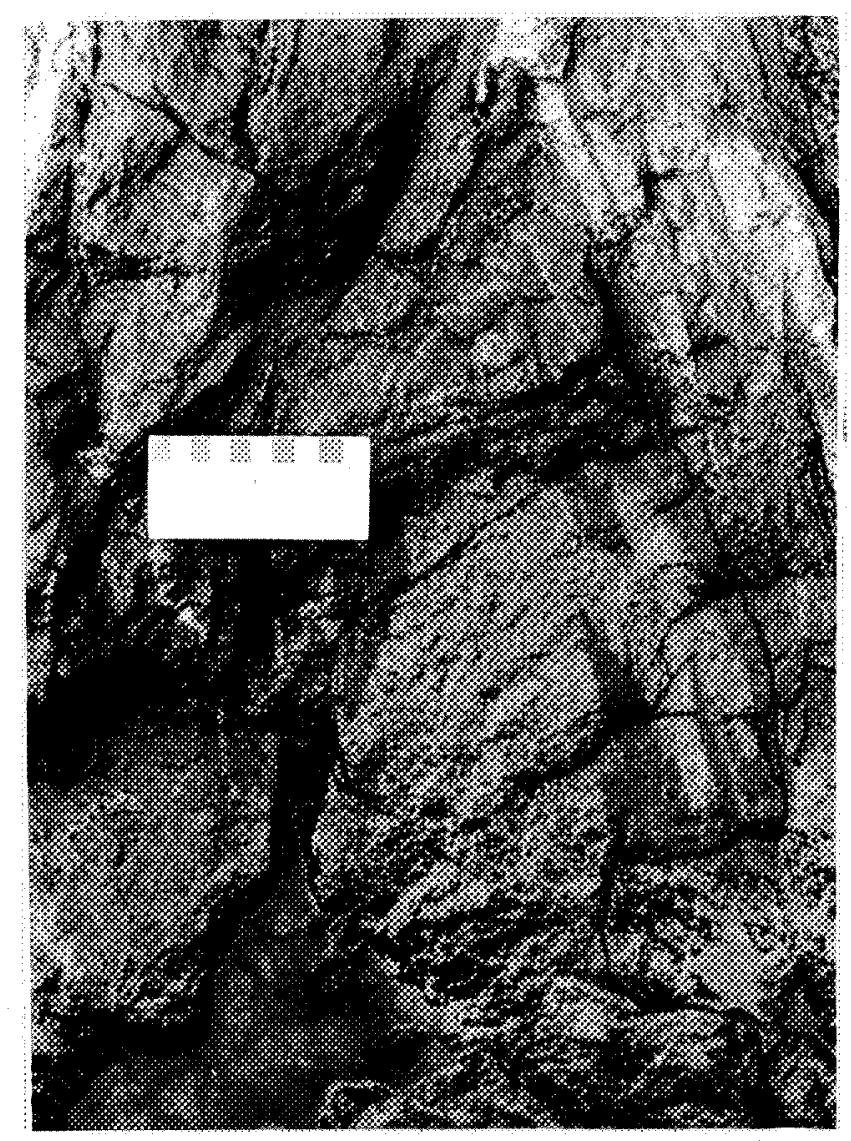

PLATE 2. 


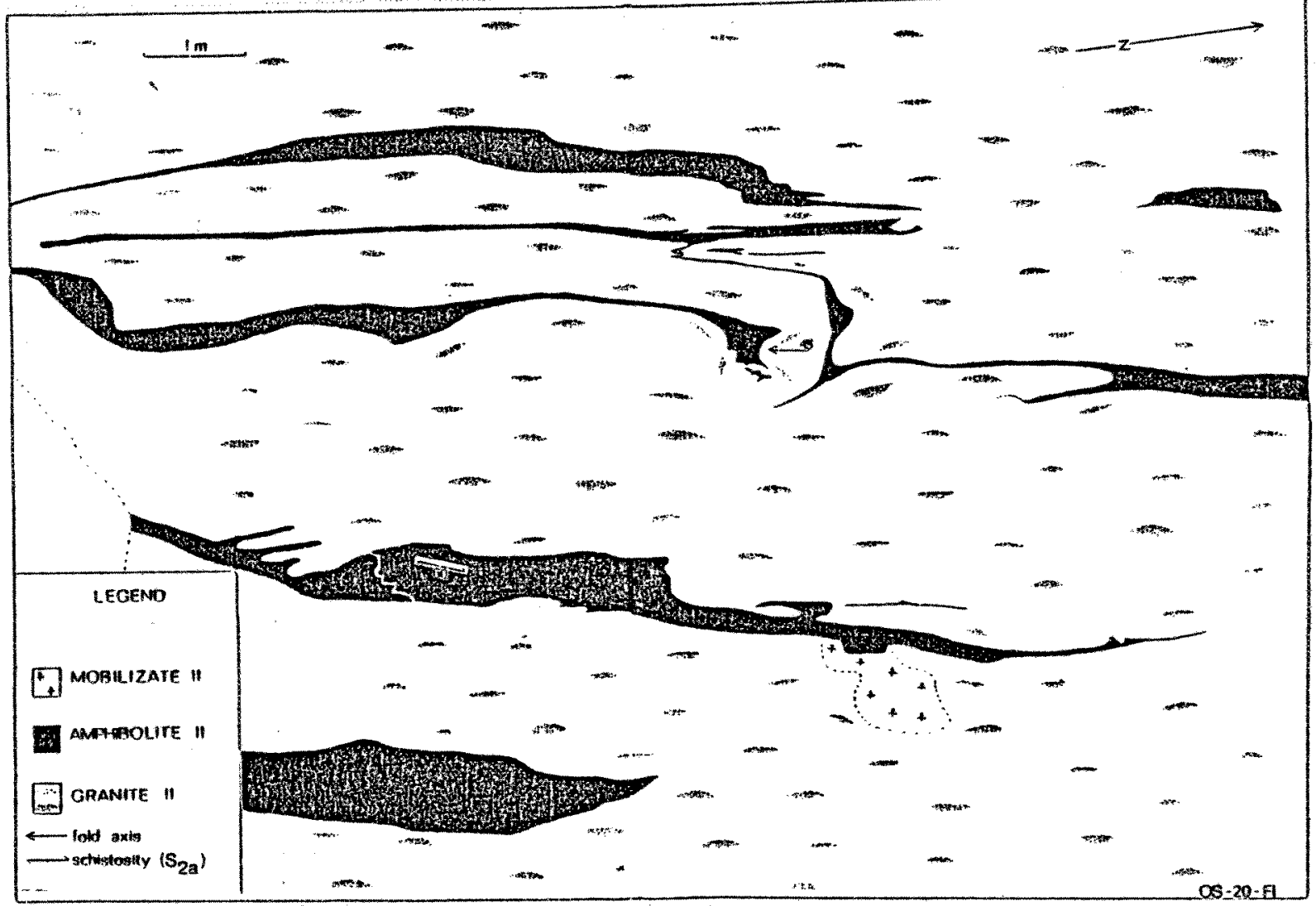

FIGURE 5. 


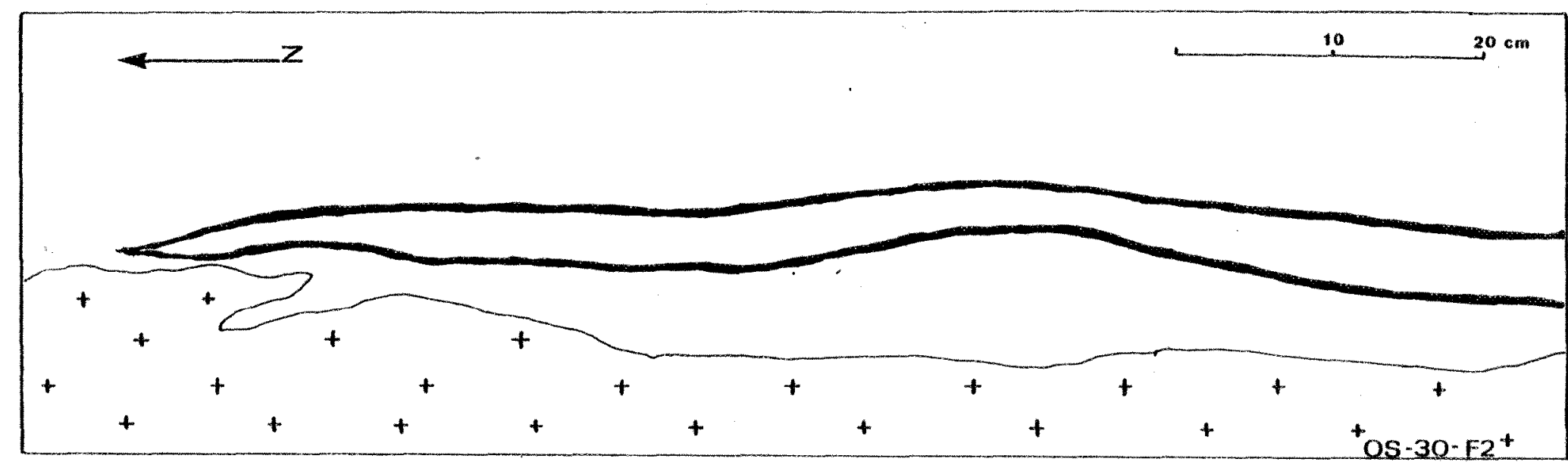

++ Pegmatitic mobilizate III $\square$ IDyke amphibolite II $\square$

FIGURE 6. 


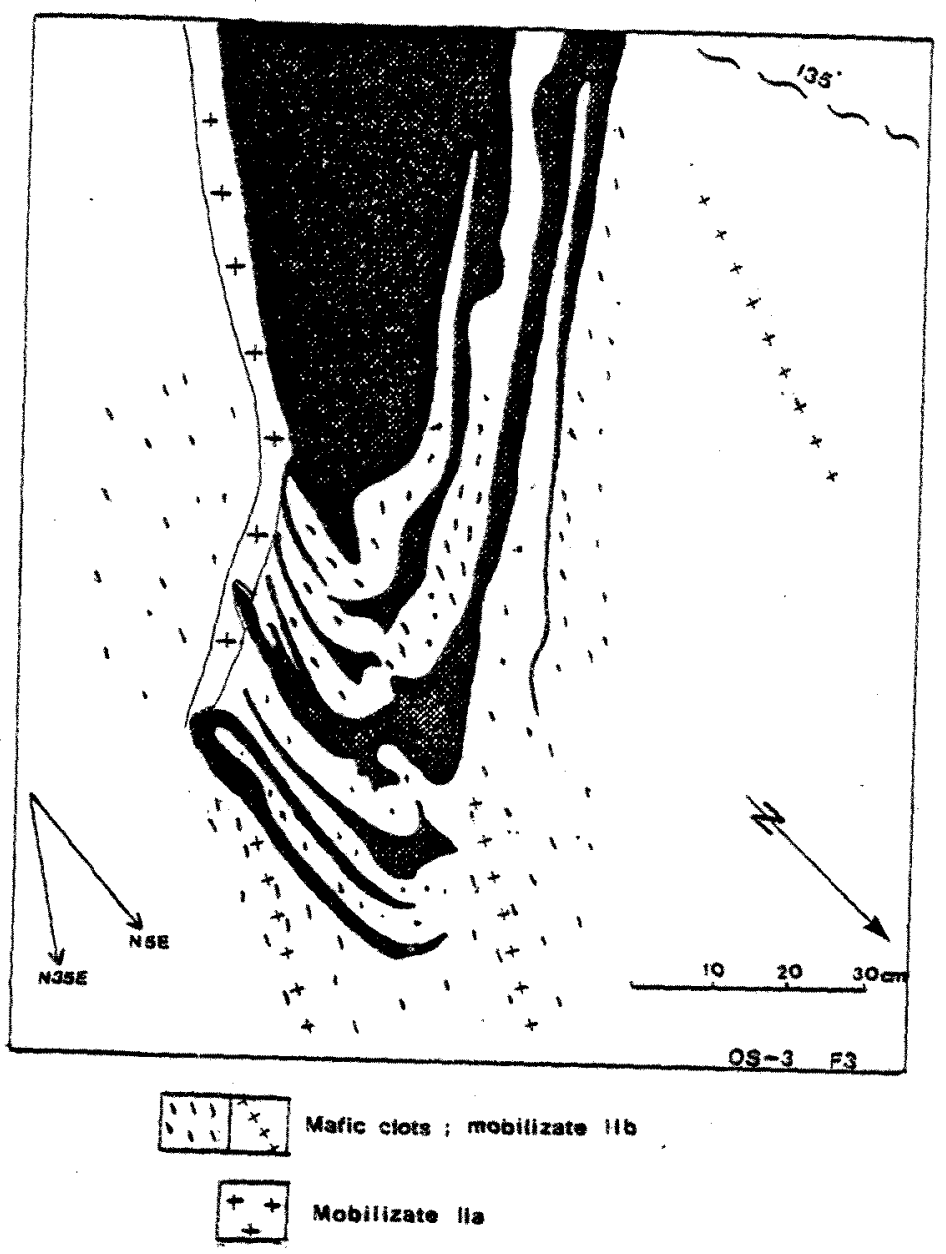

Dyke amphibollte II

Granite 1

FIGURE 7.
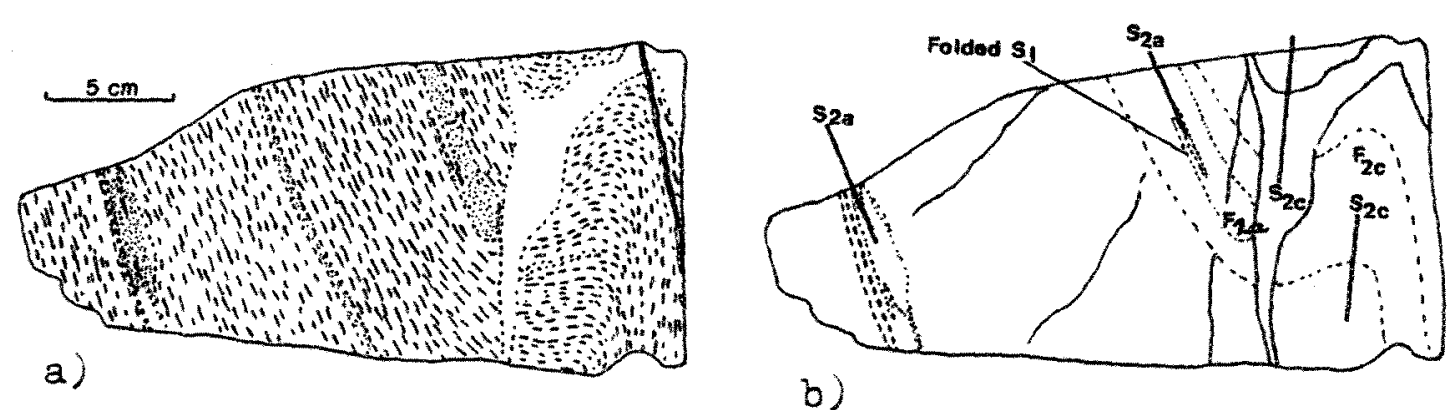

FIGURE 8. 


\section{FIGURE 9.}

Mobilizate III pegmatite, sheared by deformation III, in concordant amphibolite. The concordant amphibolite contains large volumes of mobilizates I and II, and is cut by amphibolite II dykes (ex. amphibolite IIa), outlining F2b folds. Although not indicated in the figure, the $S 3$ shearing of the pegmatite has deformed layering in the host concordant amphibolite in a manner similar to that shown in Fig. 26. Since shearing is localized within the pegmatite, we may conclude that the pegmatite intruded $\$ 3$ shear zones, crystallized, and was subsequently sheared by further $S 3$ movement: Location: highway at St. Fulgence, $5 \mathrm{~km}$ west of the ON-section. Mapping by M. Elgner and C. Schroeder. Draughting by A. Wawrzkow and $B$. Tremblay.

Figure 10.

Saguenay graben related cataclasis along thin, closely spaced shear planes, cutting coarse grained mobilizate III and host granite I and amphibolite II dykes. 


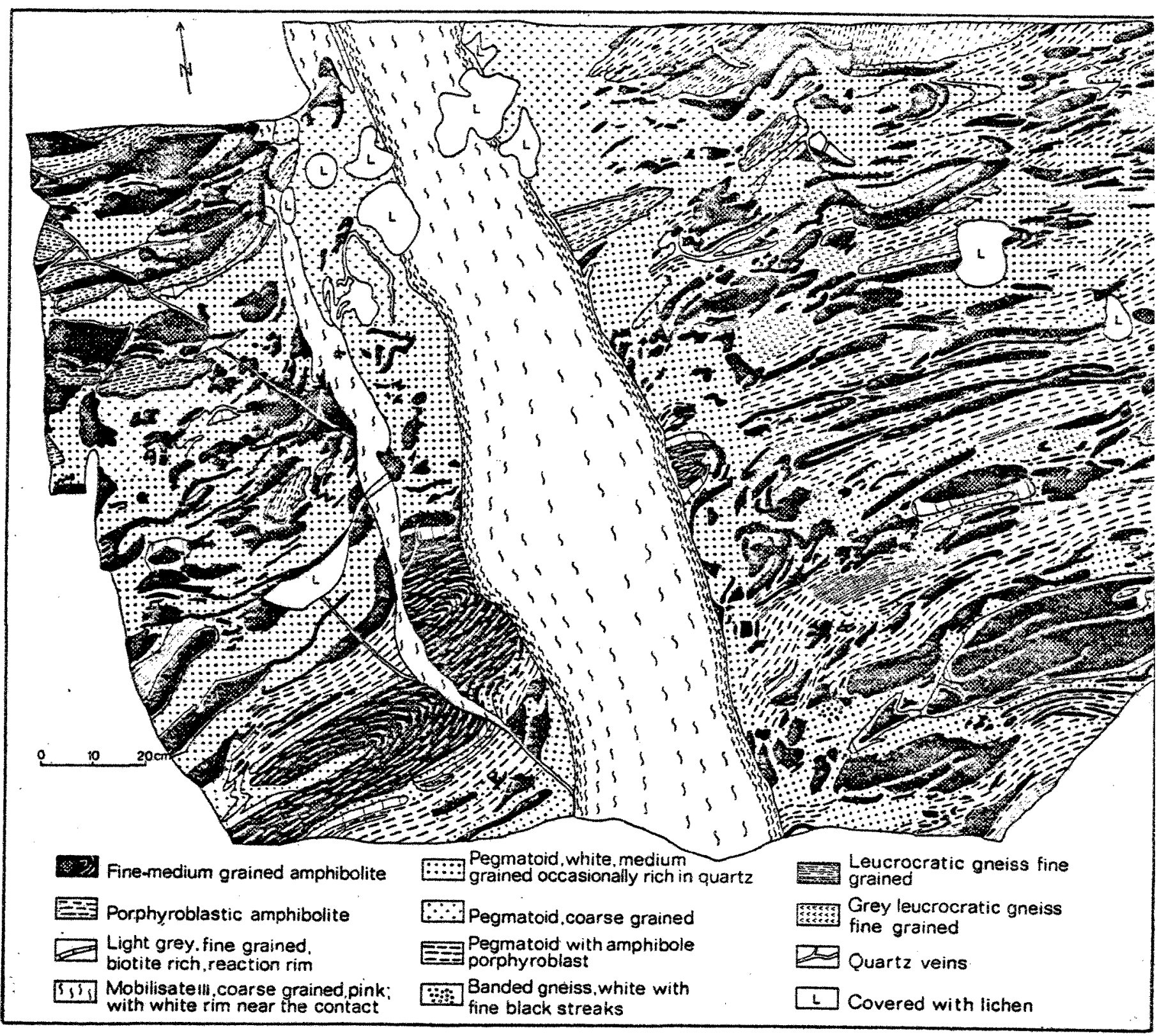

FIGURE 9. 

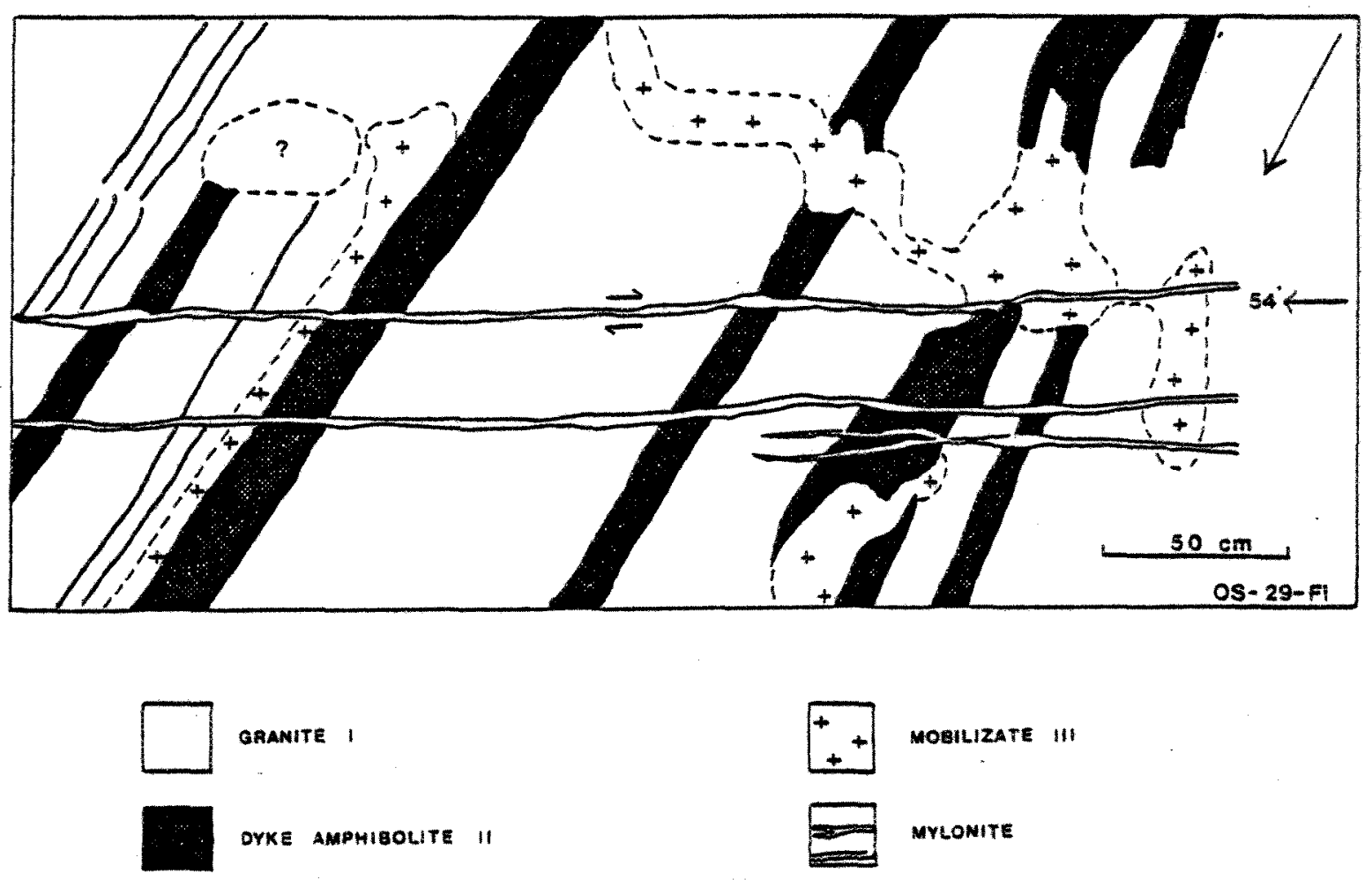

GRANITE ।

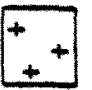

MOBILIzATE III

OYKE AMPMBOLITE

$\square$ urLontre

FIGURE 10. 
PLAT 3.

Eull guartz filing a Saruenay graben-related brecoia zone, in aranite I, at OS-3. Mote dislodged framents of the granite I nost. This material snould not be mistaken for pernatitio wooilizate III the latter always contans simnicicant quantities of potasn reldspar and/or plazloclase.

\section{PLATE H.}

ghotonicrograph of the "rylonite" shown in rig. 10, trangecting coarse grained mobilizate (top). The lack of a well defined internal fabric identifies this microbreccia as being the product of cataclasis rather than true mylonitization. Bar: 1 m. Thin section Ge ofi (sample donated to $\mathrm{L}$.H. Chown, taken rrow os-29). 
PLATE 3.

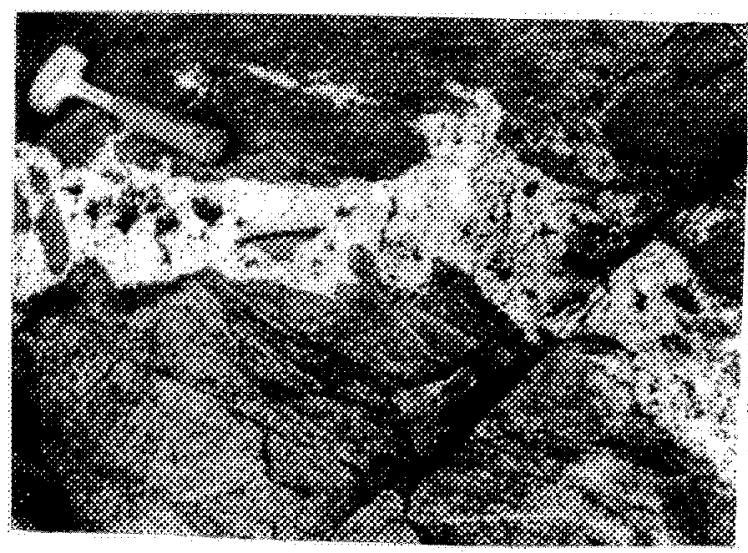

PIATE 4.

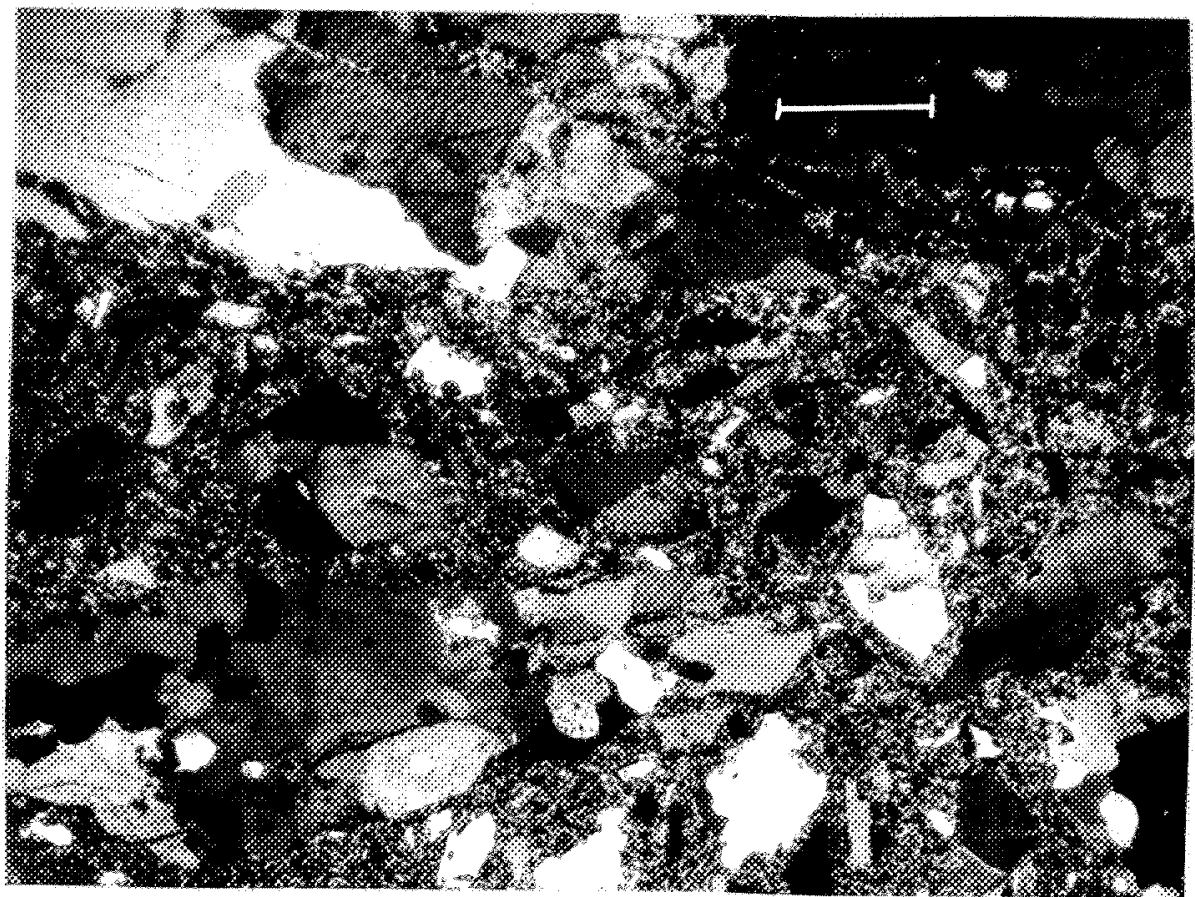




\section{B. STRATIGRAPHY.}

1-Rocks of Age Group I

The oldest rocks of the 01d Gneiss Complex (Table I) have been subjected to the first phase of migmatization, the resulting leucosomes (mobilizate I) having been thrown into flattened isoclinal Fl-folds. These rocks include paragneisses, and thick sequences of heterogeneous concordant amphibolite, and have been intruded by large volumes of finely even grained granite $I$, and lastly, by sporadically occurring amphibolite I dykes.

The paragneiss sequence outcrops for about $125 \mathrm{~m}$ along the $\mathrm{ON}$ and os sections (Fig. 2). It consists of strongly folded intercalated garnet-silimanite-(cordierite)-biotite quartzofeldspathic gneisses, quartzites, arkosic quartzites, and sillimanitic quartzites. representing pelites and semipelites, quartz arenites, feldspathic quartz arenites, and argillaceous quartz arenites, respectively. Mineral asemblages indicate that the unit has been metamorphosed to at least the sillimanite-potash feldspar subfacies of the upper amphibolite facies.

The metapelites, as a result of migmatization, and, probably, primary compositional layering (bedding) are very heterogeneous and are true migmatitic gneisses. Generally speaking, leucocratic layers (neosomes) are rich in quartz and microcline, with lesser quantities of plagioclase. Melanocratic layers are biotite-quartz-sillimanite rich, with garnet porphyroblasts up to $5 \mathrm{~cm}$ across occurring sporadically in both leucocratic and melanocratic layers. Larger garnets not uncommonly show helicitic structure, with the rotation axis possibly paralleling F2b-fold axes. Sillimanite in particular tends to be concentrated adjacent to leucocratic layers, consisting of streaks and thin $(<1 \mathrm{~mm})$ marginal seams of very finely divided grains, outlining the folded neosomes. In thin section, these same neosomes may contain tightiy folded internal silimanite-rich flasers, 
separated by sillimanite-biotite microlithons, representing F1 intrafolial folds, and identifying the neosome as a product of migmatization I (Dimroth et al, 1980). Cordierite occurs sporadically within mobilizate II leucosomes, often forming a paragenesis with garnet, quartz, microcline and sillimanite.

Within the metapelites are quartzite interbands up to $4 \mathrm{~m}$ thick. The quartzites contain 0 to $5 \%$ plagioclase and potash feldspar, rarely with up to $5 \%$ sillimanite, and traces of biotite. Biotite flakes parallel the axial planes of folded quartzite layers. Quartz in the quartzites has sutured borders, and individual grains frequently are stretched, and partiy rimmed by finely recrystallized quartz polygons.

Concordant amphibolite is typically layered on a cm-to m-scale, however a massive subvariety outrops along part of the os-section. Layering is represented by varying hornolende-(biotite):plagioclase-(quartz) ratios. Concordant amphibolite typically consists of a medium to coarse grained 10.5 to 5 $\mathrm{mm}$ ), granoblastic-polygonal textured hornblende-plagioclase rich assemblage. The percentage of mafic minerals ranges from about 25 to 50\%, although cm-scale bands containing in excess of $-60 \%$ hornblende occur local1y.

Massive concordant amphibolite contains -20 to $40 \%$ hornblende, often poikilitic, containing numerous quartz inclusions, and may contain orthopyroxene, or be cut by orthopyroxene-bearing leucosomes (Plate 5).

In both the layered and massive concordant amphibolites, the proportion of biotite is highly variable, usually less than $8 \%$, but locally surpassing $30 \%$, particularly where the amphibolite contacts paragneiss, or has been metasomatized by pegmatite dykes.

Folded (Plate 6) and boudinaged (Fig. 11) decimetre-thick calcsilicate layers seen here and there in the layered concordant 


\section{FICURE 11.}

Boudinaged, fine grained, pale green calcsilicate layers in banded concordant amphibolite. The coarse grained pegmatoid is metasomatizes (biotitizes, silicifies) amphibolite inclusions. Consequently, it is believed that the thin networks of pegmatoid in the outcrop are mobilizate III. Irrezular hornblende clots appear to be recrystallization products related to pegmatoid intrusion. These hornblences are coarser grained than amphibolite hornblendes, and form clots consisting almost wholly of amphibole. 


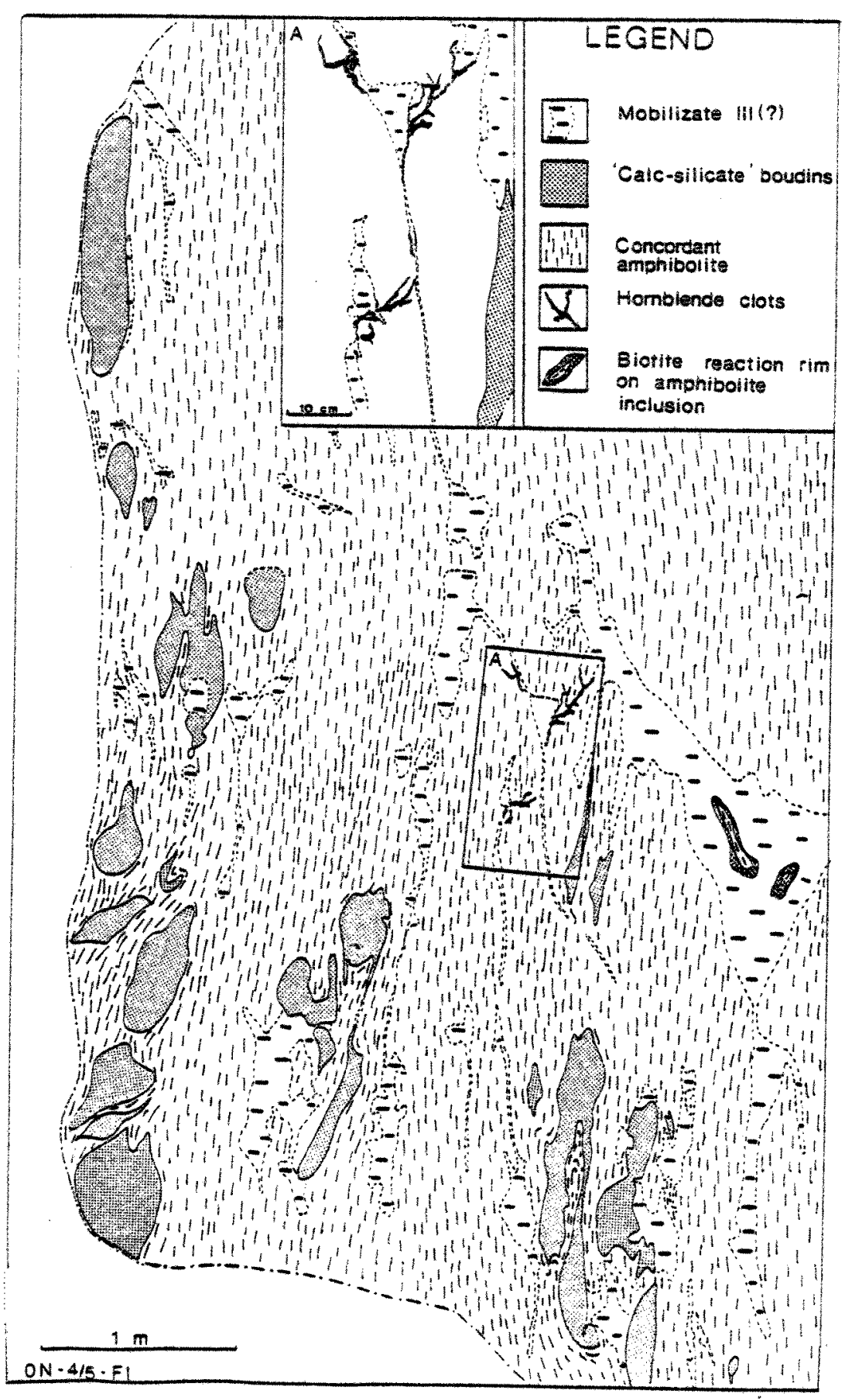

FIGURE 11. 


\section{PLATE 5.}

Coarse grained orthopyroxene rich networks of leucosomes cutting massive concordant amphibolite, at $0 S-24$. Leucosomes were generated during migmatization If.

\section{PLATE 6.} Folded calcsilicate layer in banded concordant amphibolite.
Location: ON-5.

\section{PLATE 7 .}

Photomicrograph of clinopyroxene (c) in aranite $I$. The rock is rich in quartz $(q)$ and microcline (m), This is the only sample of granite I seen to contain clinopyroxene: it does so at the expense of hornblende, a common wafic mineral of granite I in the study area. Thin section $0 \mathrm{~N}-2-6$. Bar: $0.5 \mathrm{~mm}$. X-nicols. 
PLATE 5.

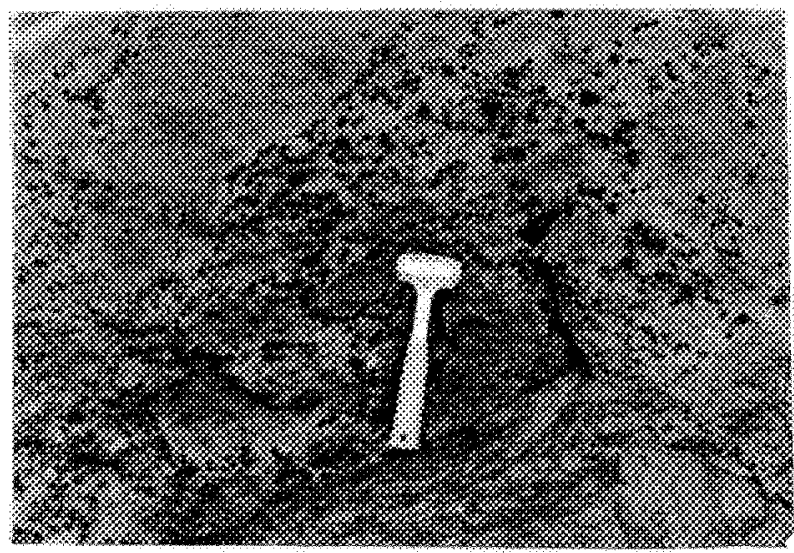

PLATE 6.

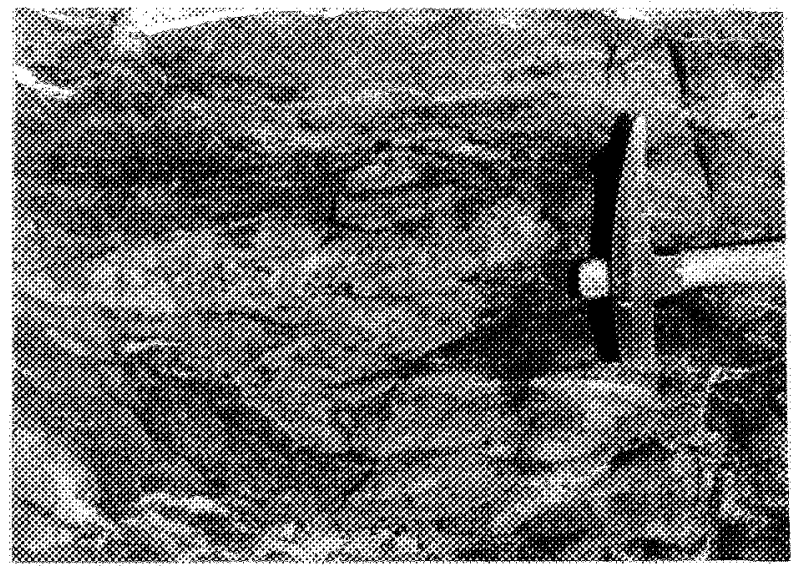

PLATE ?.

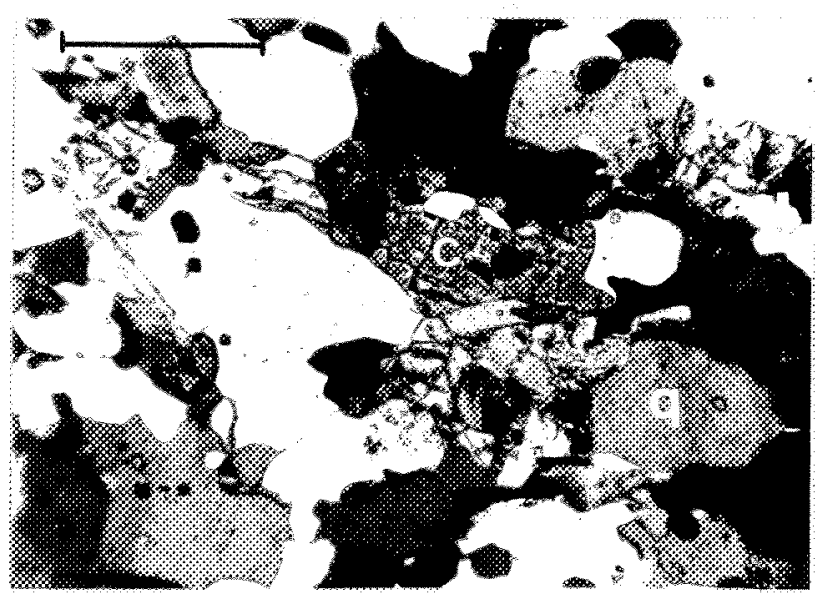


amphibolite sequence have a granoblastic texture, consisting of fine grained (average about $0.25 \mathrm{~mm}$ ) subhedral, moderately to strongly sericitized plagioclase (35\%), polygonal quartz (20\%), pale green diopside (40\%) with minor amounts of sphene, typically mantiing opaques. Locally, fine grained aggregates of orange brown garnet (grossularite?) occur in the calcsilicate. A few green hornblende crystals are found in the calc-silicate where it contacts the concordant amphibolite, however, this contact is invariably sharp and well defined, in thin section as well as on the outcrop.

Granite $I$ is a homogeneous, rose to grey coloured, fine grained $(\tau 0.5 \mathrm{~mm})$ granoblastic biotite and hornblende-biotite leucogranite. Locally the granite is clinopyroxene-bearing (Plate 7). The homogeneity of the unit renders it an ideal candidate for quantitative study of neosome morphology, insofar as a well defined paleosome is always present. The homogeneity of the rock also precludes the possibility that the unit is a meta-arkose, insofar as no gradational contacts between granite I and quartzites have been seen within the study area. Dimroth et al (1980) indicate that intrusive contacts have been seen in at least one locality. Approaching the paragneiss sequence along both the $O N$ - and OS- sections, granite $I$ and paragneissic rocks may be intercalated on a centimetre (Fig. 12) to a decametre (Fig. 2) scale, This may represent thin granite I sills intruding the marginal borders of the paragneiss sequence, the interlayered effect possibly being accentuated by folding.

The youngest rocks of age group I consist of rare, thin amphibolite dykes, here termed amphibolite I dykes. Probable examples of these include a) thin subconcordant dykes in an inclusion of granite I within charnockitic gneiss (age group II) wherein the amphibolite dykes are terminated at the inclusion-charnockite host interface (Fig. 13); and b) tightly folded (F2) relict dykes (?) containing abundant mobilizate I material (Fig. 14, Plate 8), in granite I host rock, cut by simply folded (F2b) amphibolite II dykes devoid of mobilizate I material (Fig. 15). 
Although these may represent dyke amphibolites, they may, particularly in the latter case (Figs. 14, 15) consist of stretched inclusions of concordant amphibolite.

An interesting observation regarding Fig. 13 is the high angle of the schistosity of the granite I inclusion (marked by the concordant dykes) to the schistosity within the charnockitic gneiss host. According to the model presented in section IIA, the dominant schistosity (S2a) in rocks of age groups $I$ and II formed "simultaneously", following injection of amphibolite II dykes. This, in light of Fig. 13 and the local occurrence of intersecting "S2a" (?) schistosities in the granitic rocks of age group II (Plate $9 b$ ) indicates that this explanation of S2a-formation is an oversimplification of the actual process. However, bearing in mind the marked and consistent parallelism of the dominant schistosities (S2a) within all rocks (including amphibolite II dykes) of age groups I and II, the present model supporting "simultaneous" schistosity-formation proves to be a pragmatic, albeit incomplete, compromise. Local, contradictory observations may indicate the very plausible existance of relicts of pre-S2a foliations, possibly primary (ex. igneous), in the intrusive rocks, since largely overprinted by the s2a schistosity.

\section{Rocks of Age Group II}

A major group of granitic intrusive rocks and felsic to mafic dykes constitutes the rocks of age group II. None of these rocks contain products of migmatization $I$, nor do they show effects of deformation I. Unlike rocks of later age groups (age group III, and younger), rocks of age groups $I$ and $I I$ suffered the effects of migmatization IIa,b and deformations IIa,b,c (Table 2 ). 


\section{FIGURE 12.}

Thin interbands of paragneiss within granite $I$, as seen approaching the paragneiss sequence along the OS-section ( $c$.f. Fig. 2). Note the minor displacement of Saguenay graben-related fauting.

FIGURE 13.

Truncation of probable amphibolite I dykes, concordant within a granite I inclusion, at contact of the inclusion with the streaky textured charnockitic gneiss host rock. 


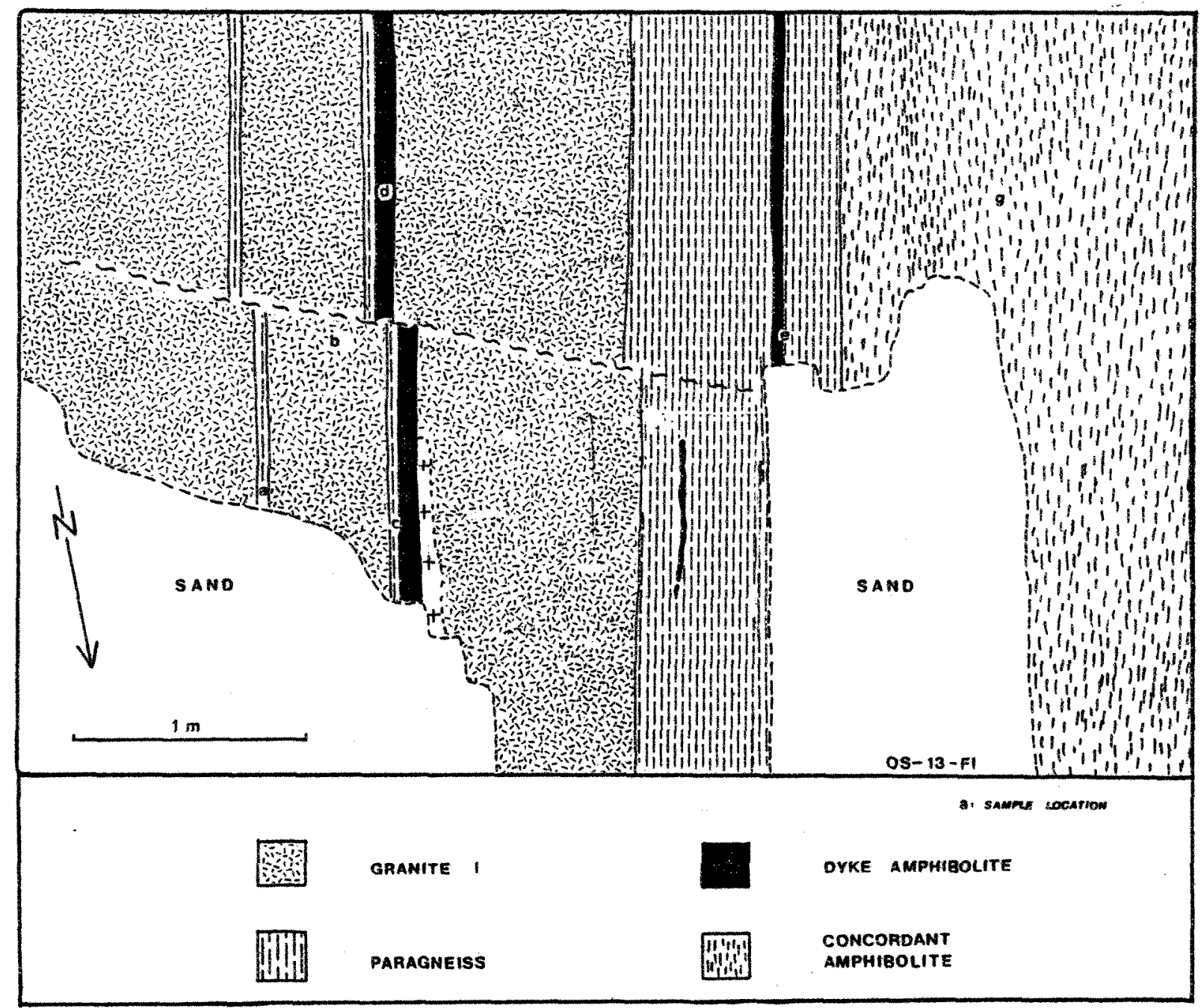

FIGURE 12.

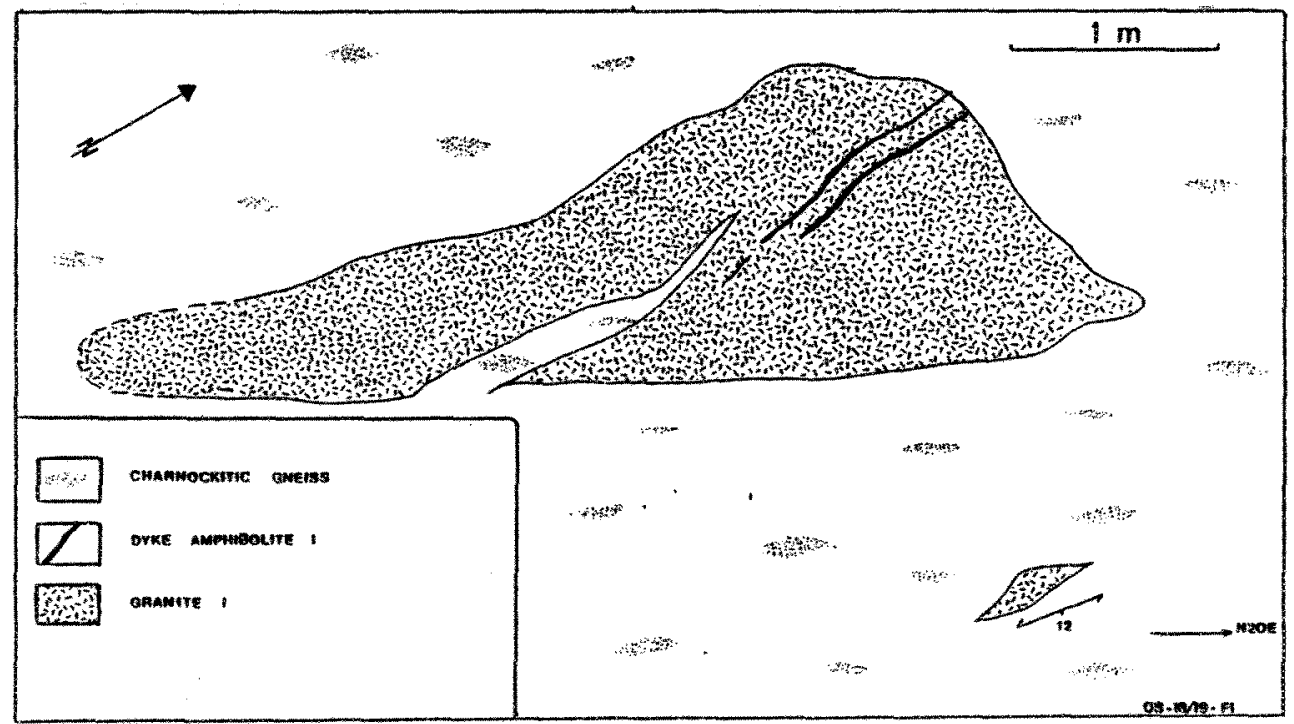

FIGURE 13. 


\section{FIGURE 14.}

Possible dyke amphibolite I material in granite $I$. This material contains abundant mobilizate I leucosomes (enlargement, and Plate 8) showing isoclinal F2a-folds, here refolded by F2b. The dyke (?) amphibolite I is cross-cut by the amphibolite II dykes (c.f. Fig. 15), which are entirely devoid of mobilizate I leucosomes. Although this may be a dyke amphibolite, it cannot be excluded wat this material is an inclusion of concordant amphibolite within the granite I, subsequentiy injected by amphibolite II dykes after migmatization I.

\section{PLATE 8}

Photograph of a thin offshoot of dyke (?) amphibolite I material represented in Fig. 14. Note tight Faa-folded mobilizate I veins (grey), and the notable sparsity of leucosomes in the granite I host. 

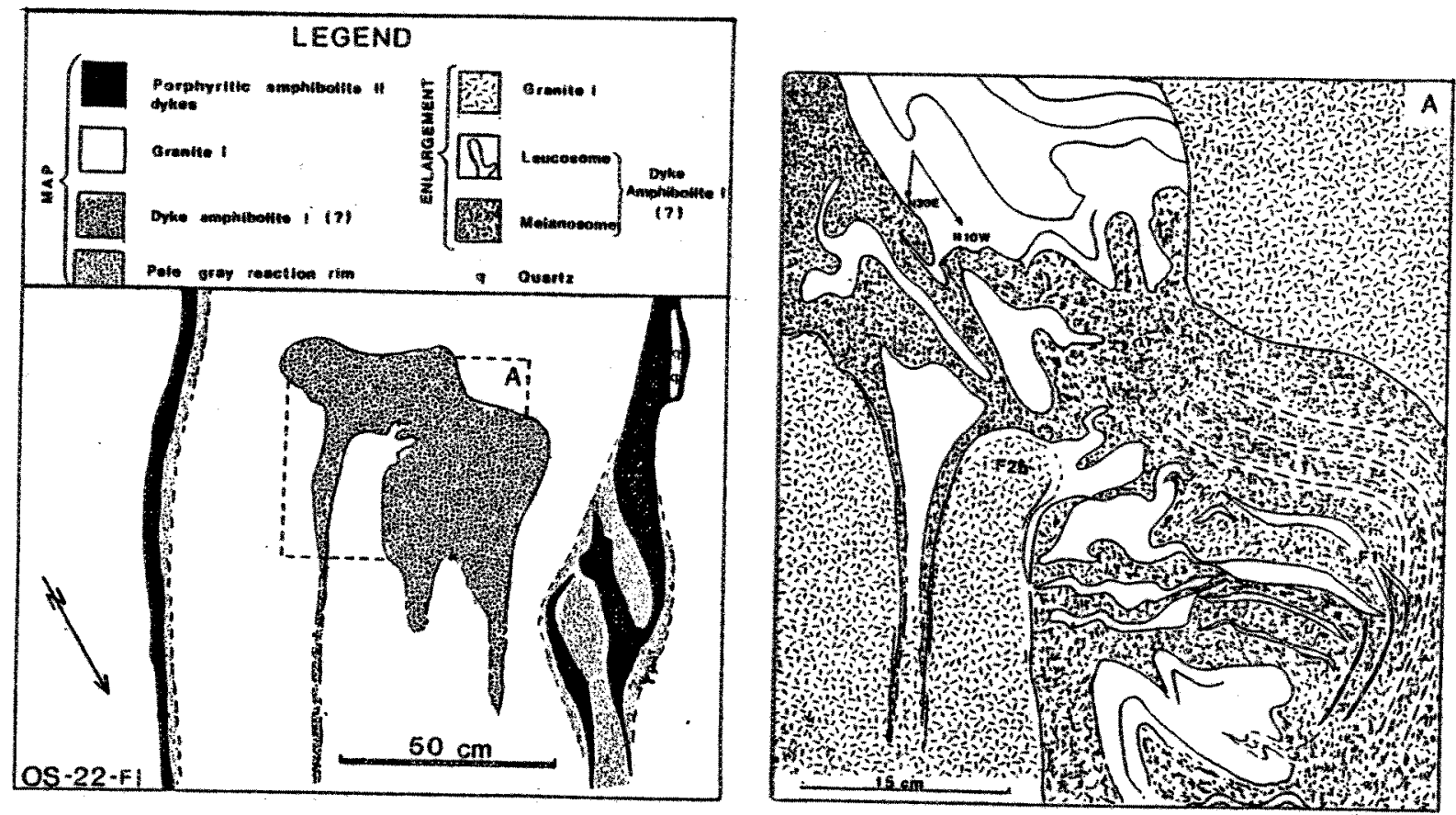

FIGURE 14.

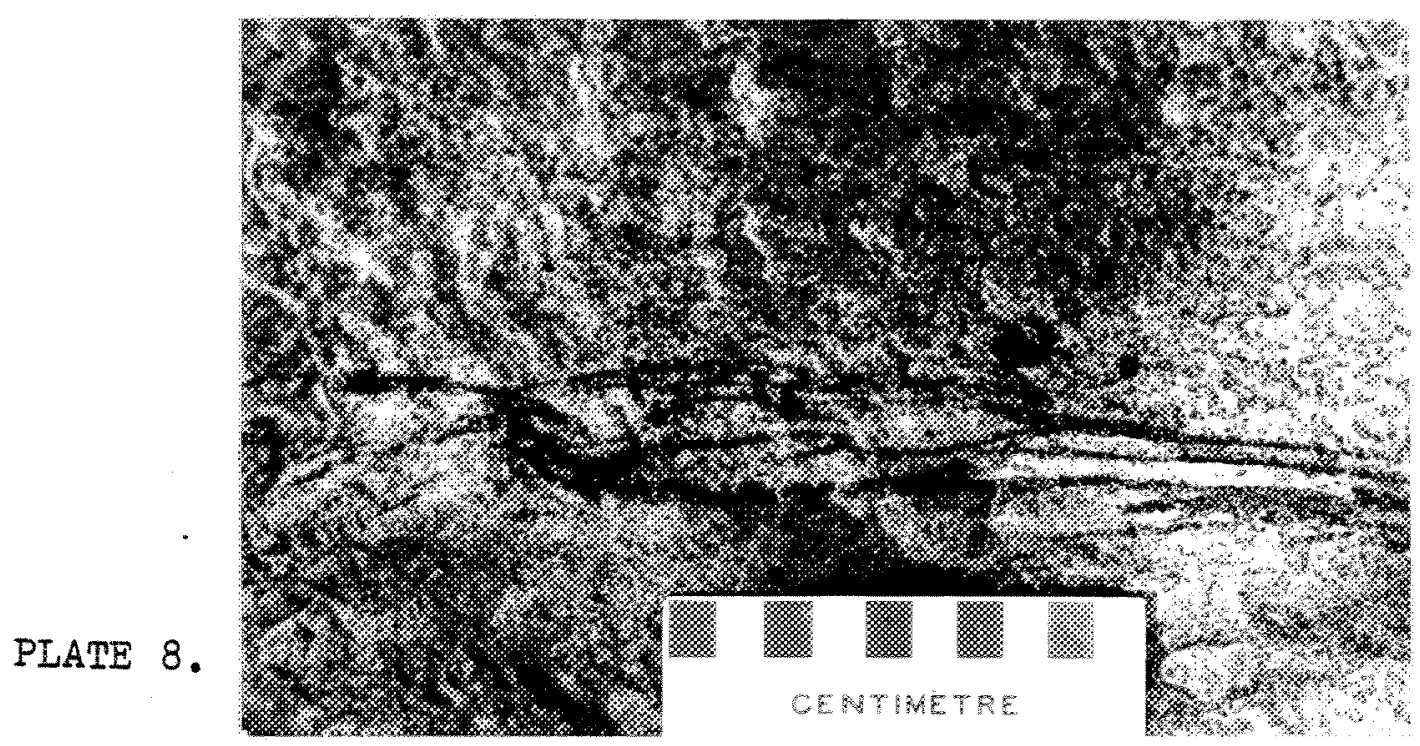




\section{FIGURE 15.}

Possible amphibolite I dyke cross-cut by an amphibolite IIb dyke, in granite I host. Irregular shape of the amphibolite I dyke (?) near intersection reflects F2a folding in the dyke (?), as outined by mobilizate I veins, which are absent in the amphibolite II dykes. Note the accumulation of mobilizate II material, stemming from granite I, near the "sink" formed at the intersection of the dykes. See also Fig. 14 and Plate 8. 


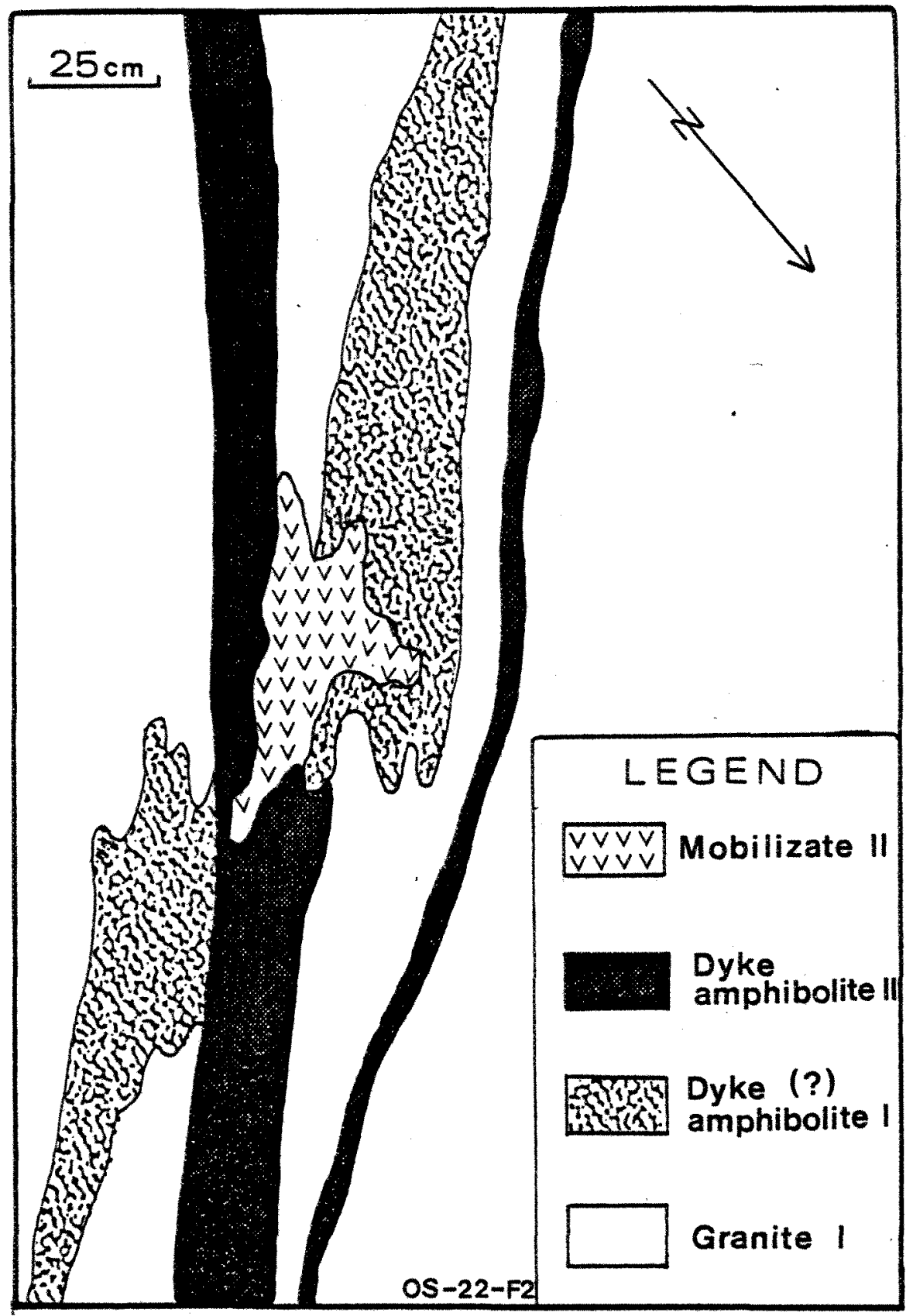

FIGURE 15. 
Three varieties of medium grained subsolvus granitic rocks are recognized. Granite IIa consists of pink coloured, streaky textured granite gneiss. The streaky texture is defined by 1 to $3 \mathrm{~cm}$ long, 1 to $3 \mathrm{~mm}$ wide aggregates of biotite or biotite-hornblende, not uncommonly with hypersthene, and by elongated potash feldspar (microcline, perthite)- and strained quartz- rich aggregates of similar dimensions. The rock is leucocratic; total mafics do not exceed $7 \%$. The streaky texture represents the $52 a$ schistosity, prevalent in all rocks of age groups $I$ and II.

Here and there, decimetre to metre scale greenish coloured bands occur within granite IIa, both concordant and discordant to the S2a foliation (Plates $9 \mathrm{a}$, ). These bands also are streaky textured granitic rocks, compositionally similar to granite IIa, however, hypersthene is usually present in small ( $<1$ to $5 \%$ ) quantities. Consequently, these bands, which are, volumetrically, the most important rocks of age group II within the study area (Fig. 2), are classified as charnockitic gneiss. Considering the textural and mineralogical similarity of the charnockitic gneisses to granite Ila, they may represent volatile-transformed equivalents of granite IIa, or, more likely, precursors of granite IIa, the latter being the oxidized member. Concordant interbanding of the two rock types is common along the OS-section (Plate 9a); "discordant" bands are not intrusive, since the $\mathrm{S} 2 \mathrm{a}$ schistosity passes unhindered through the banding. Rather, discordant color banding indicates local reducing (or oxidizing for pink bands in charnockite gneiss) metasomatizing fronts, whose migration locally disregards schistosity.

The charnockitic gneiss locally contains hypersthenes up to $6 \mathrm{~mm}$ across, lending a spotted rather than streaked appearance to the rock. These hypersthenes may be partly mantled by retrograde green hornblende (Plate 10 ). 
PLATE 9. Features of Granite IIa.

a. Concordant contact between rose coloured streaky-textured granite IIa (above) and greenish coloured streaky-textured orthopyroxene-bearing charnockitic gneiss (below). Location: OS -20 .

b. Apparent discordant relationship between streaky granite IIa (Below, scale follows $\mathrm{S} 2 \mathrm{a}$ ) and granite IIb augengneiss (above). However, the intrusive contact, indicated by $\$ 2 a$ in granite IIb "cutting" (?) S2a in granite IIa is, as such, ambiguous. The contact itself is sheared, therefore it is likely that this is a tectonic contact, not an intrusive relationship. Location: $0 S-20$.

\section{PLATE 10.}

Photomicrograph of the retrograde mantling of orthopyroxene ( 0 ) by hornblende (h), in charnockitic gneiss. Microcline (m) and quartz (q) occur as matrix minerals. Thin section ORM-3-8. X-nicols. Bar: $1 \mathrm{~mm}$. 
PLATE 9a.

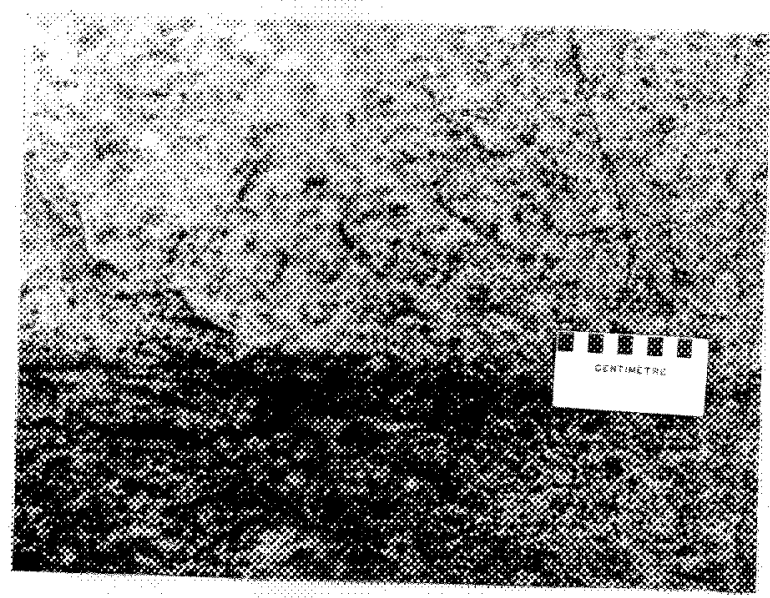

PLATE 9b.

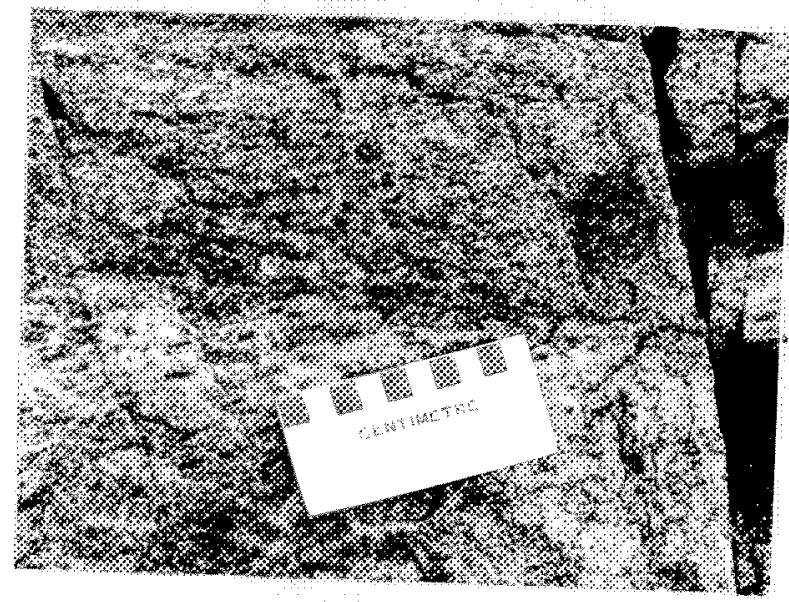

PLATE 10.

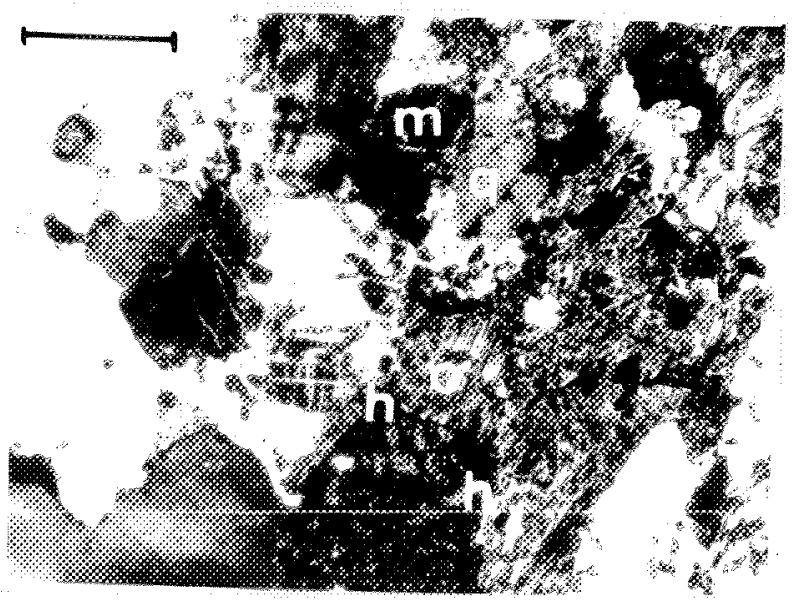


Granite IID is a rapakivi-textured, potash feldspar rich biotite (-hornblende) augengneiss. Augen structures are tabular to lens-like in shape, averaging about $20 \mathrm{mII}$ long and $7 \mathrm{mb}$ wide; stretched augen-structures are longer and thinner. These consist of perthite, quartz, and plagioclase, with mafic minerais (hornblende, biotite) and plagiociase separating and rimming augen. Since no definite intrusive contacts between granite IIb and granite IIa/charnockite gneiss have been observed, granite IIb way only tentatively be placed above granite IIa in the stratigraphic column. Evidence supporting this tentative chronology is presented in Plate $9 b$, where granite IIb apparently truncates S2a-schistosity in the streaky granite IIa. This relationship returns us to the problewatical timing of formation of the dominant schistosity $(S 2 a)$, in rocks of age groups $I$ and II, as discussed in section II-A,B(fig. 13). The apparent cross-cutting relationship shown in Plate 90 may be misleading insofar as the contact between the two lithologies shows evidence of shearing, so this may be a tectonic rather than intrusive contact.

Granite IIb commoniy contains hypersthene metacrysts, consequently, it way be stated that all granitic rocks of agegroup II in the stucy area locally are charnockitic.

All rock types described above have been intruded by larze volumes of felsic to mafic dykes, ranging in thickness from a few centinetres to $5 \mathrm{~m}$. These dykes with few exceptions are concordant to subconcordant to $52 a$ in their host rocks. However, since the dykes themselves contain a strong $52 a$ cleavage, it is deduced that $F 2 a$ postdates dyke injection. That dykes of age group II antedate migwatization II is indicated by the accumulation of mobilizate II material, derived from the dyke's host rocks, in interstices between boudinaged dykes, less comonly by the presence of in situ neosomes within the dykes themselves. 
A chronology of dyke injection has been established from cross-cutting relationships. Since even-grained amphibolite dykes are volumetrically the most important dykes within the study area, in general, all compositions of dykes of age group II are referred to as amphibolite II dykes. A "dyke" prefix distinguishes the intrusive amphibolites from the "concordant" amphibolites of age group $I$.

Amphibolite II dykes most frequently parallel host rock schistosities, dominantiy S2a, and compositional layering. However, cross-cutting relationships are not unknown, even where primary compositional layering might be expected to provide preferred control of intrusion (Figs. 16, 22).

The oldest documented dykes of age group II within the study area are hornblende-phyric amphibolites. The thin section examined of this material juxtaposes perthite-rich mobilizate IIa material in granite I host rock (thin section OCJ-FIb; C.f. Fig. 17) and contains greenish-brown hornblende phenocrysts (Plate 11a), representing uralitized pyroxene, partly altering to chlorite. The groundmass of the amphiboles consists of string perthite, with lesser quantities of quartz and plagioclase. These dykes are termed "amphibolite IIa dykes" (Table 2), and are cut by even-grained amphibolite IIb dykes (Fig. 17).

Even-grained amphibolite dykes are volumetrically the most important dykes within the study area. They are granoblastic, hornblende (-biotite)-plagioclase rich assemblages, in which the total mafic content varies from about 25 to $65 \%$, averaging perhaps $40 \%$ (Plate 11b). Locally, amphibolite IIb dykes contain saussuritized plagioclase phenocrysts (Plate 110). An interesting feature observed at $\mathrm{ON}-3$ is the occurrence of garnetiferous lineations, apparently paralleling F2b-fold axes, formed along the contact between amphibolite IIb dykes and host paragneiss. Garnets form along the contact interface, and within the dyke, from 2 to $>15 \mathrm{~cm}$ from the 
interface. The garnetiferous marginal zone of these dykes contains biotite at the virtual exclusion of hornblende; the hornblende/biotite ratio increases toward the centre of the dyke. Some of the garnets in this zone contain sillimanite (Plate 11d).

Amphibolite IIb dykes are cross-cut by dioritic dykes, rich in quartz and plagioclase, with lesser amounts of orthoclase, and mafics (biotite, hornblende, traces of clinopyroxene-Plate 11e) totalling -15\%. In the case of thin section OS-26-F1a (Fig. 18), the biotite (Plate 11f) defines a strong axial plane schistosity, paralleling both the biotite/hornblende S2a schistosity in the granite I host rock, and concordant amphibolite IIb dykes, cut here by the dioritic dyke. These relations identify the folding of the discordant dyke, and the boudinaging of the concordant IIb dykes, as being the result of F2a-folding. As such, the axial plane schistosity in the folded IIc dyke (Plate 11f) corresponds with $\$ 2 a$, which normally is itself folded by $F 2 b$.

A series of consistently fine grained granitic dykes outcrop within the study area, particularly along the os-section. The age of these dykes relative to dykes $I I a, b, c$ is unknown, however, their grouping among rocks of age group is justified insofar as these dykes have been folded by F2b Fig. 19), and locally are cross-cut by mobilizate II veins originating from host gneisses ( (Fig. 20). It is likely that these dykes antedate amphibolite IIb dykes, since in at least one case the granitic dyke appears to have had an amphibolite IIb dyke injected along the contact of this dyke with its host granite Ila (Plate 12). In another case, a dark weathering even-grained amphibolite IIb dyke intersects a pale weathering, leucocratic granitic dyke (Fig. 21). In this case, the dyke contains biotite, not hornblende as the major mafic mineral.

In thin section, these granitic dykes are seen to be rich in potash feldspar (perthitic orthoclase and microcline) and quartz, with 
FIGURE 16.

Discordant amphibolite IIb dykes in paragneiss.

FIGURE 17.

Amphibolite-phyric IIa dykes cross-cut by even grained amphibolite IIb dykes, in granites I and IIa. The contact between the granites is concordant (parallels $\mathrm{S} 2 \mathrm{a}$ in both units), and the boudinaged/brecciated IIb dykes are concordant. The anomalous relationship seen in the concordant dyke near the contact between the two granites is the result of "smearing" of the IIa dyke across the IIb dyke. Inset shows mobilizate I veins cut by mobilizate II veins following the IIa dyke. Note the intersecting mobilizate IIa veins, indicating that products of migmatization Ila were not all concomitantly fluid. Note also that the mobilizate II material migrating into brecciated/boudinaged IIb dykes has as its source the granite immediately enclosing the dykes. Thus, the mobilizate found within the IIb dyke within the granite I (left) is different from that found in dykes within the granite IIa. These differ insofar as the mobilizate stemming from granite IIa is finer grained, and locally recrystallizes the dyke amphibolite, producing melanocratic, recrystallized hornblende-rich margins on some brecciated dyke fragments. The mobilizate within granite. IIa is coarser grained, resembling mobilizate III, and recrystaliizes the amphibolite also, yieloing pale grey thin $(5 \mathrm{~mm})$ recrystallized margins surrounding amphiblite fragments. Both mobilizates are rich in potash feldspar. The granite IIa material, although pegmatitic, is demonstrably not mobilizate III, despite the absence, of melanosomes in veins within the granite, since this material forms cm-thick, metre-long concordant (less commonly discordant) veins widespread throughout the granite. IIa exposure. No similar material was noted within granite I, as would be expected if the material was allochthonous (ie pegmatite injections would not mobilizate II leucosomes in granite II exposures elsewhere within the study area are not seen to be bounded by melanosomes. 


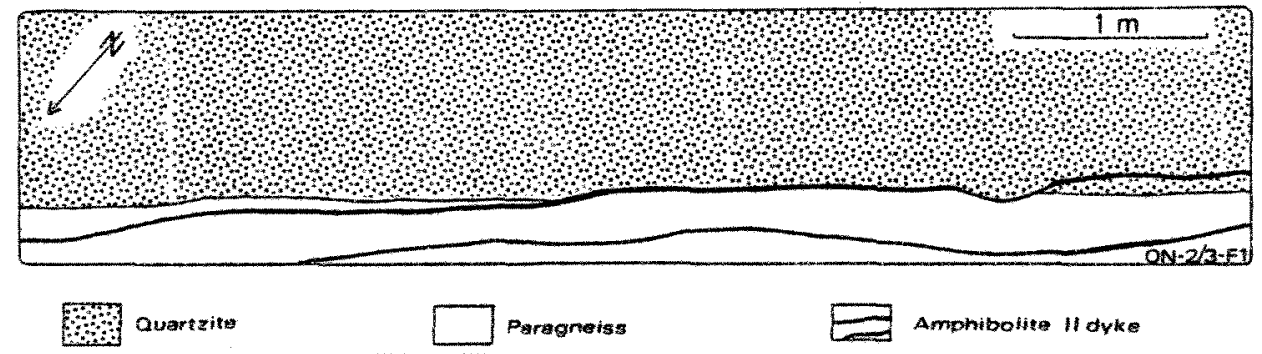

FIGURE 16.

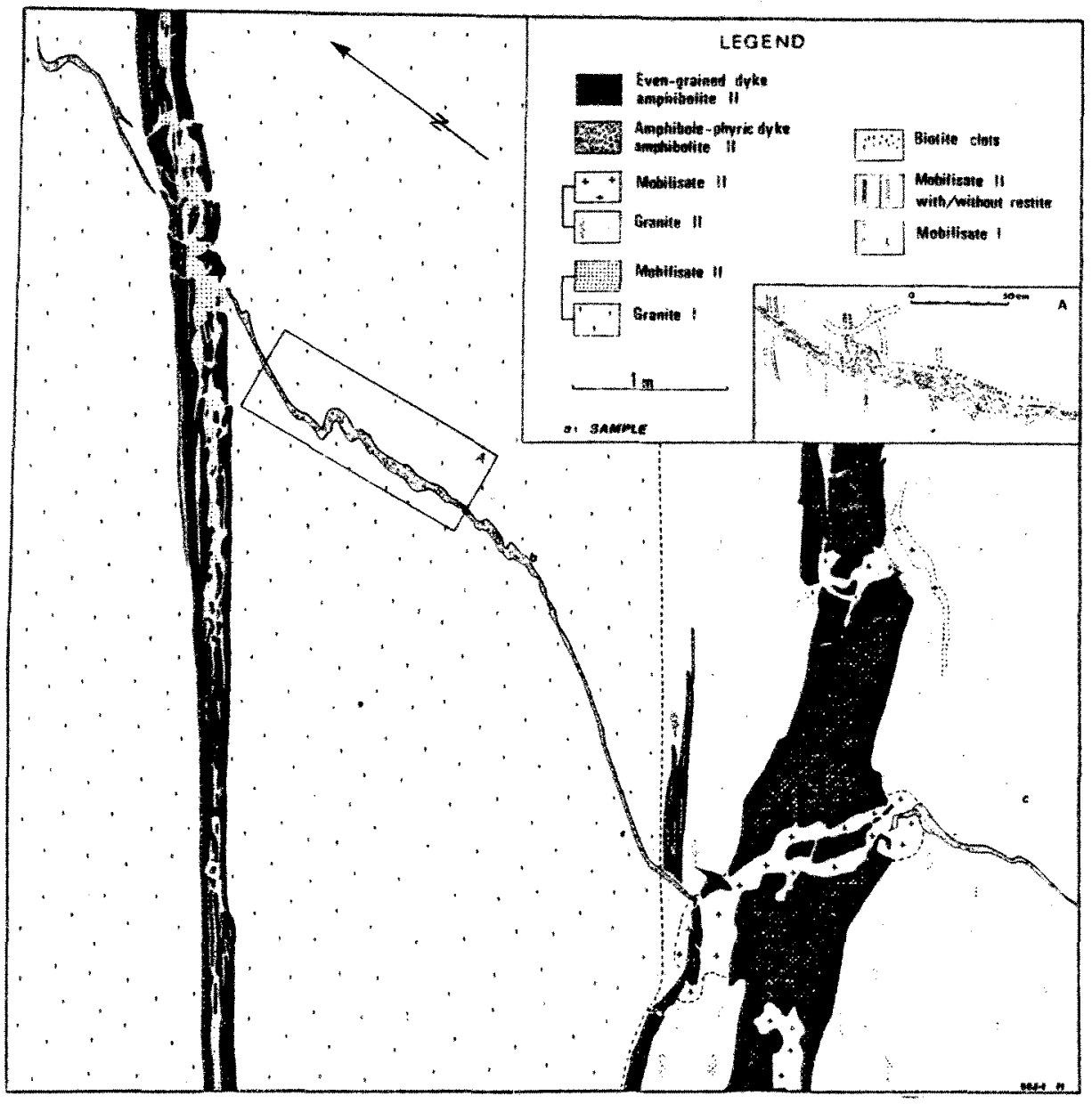

FIGURE 17. 
FIGURE 18.

Folded leucocratic (dioritic) IIc dyke cross-cutting concordant, even grained amphibolite IIb dykes in granite I. The dioritic dyke contains a strone axial planar schistosity (marked by biotite-c.f. Plate 11f) paralleling the S2a schistosity in the granite $I$ and boudinazed amphibolite IIb dykes. Since S2a is axial planar to these folds they are F2a folds. Boudinared concordant IIb dykes were deformed concomitantly with F2a folding. Note the axial planar orientation of mobilizate II veins in the Ilc dyke, indicating $S 2 a$ control on neosome localization.

FIGURE 19.

Fab folded evenly fine grained granitic dykes of age group II, within streaky textured granite IIa.

FIGURE 20.

Uncorrelated evenly fine grained granitic dyke of aze group II, discordant within the paragneiss sequence along the os section. The dyke traverses the contact between biotite-garnet paragneiss and $a$ band of granite I (?) (possibly a quartzofeldspathic biotite paragneiss). Note that a vein of garnetiferous, medium grained pink coloured mobilizate II cuts the dyke, demonstrating its aze relative to migmatization II.

FIGURE 21.

Concordant evenly fine grained granitic dyke of aze group II, being cross-cut by a probable even grained dyke amphibolite IIb. Note the products of migmatization. II in the granitic dyke (feldspathic streaks and mobilizate vein).

PLATE 12.

Uncorrelated evenly fine grained granitic dyke of age group II, with a thin even grained amphibolite IIb dyke intruded along one contact. Note how the amphibolite dyke bifurcates within the granite IIa host. Location: OS-21. 


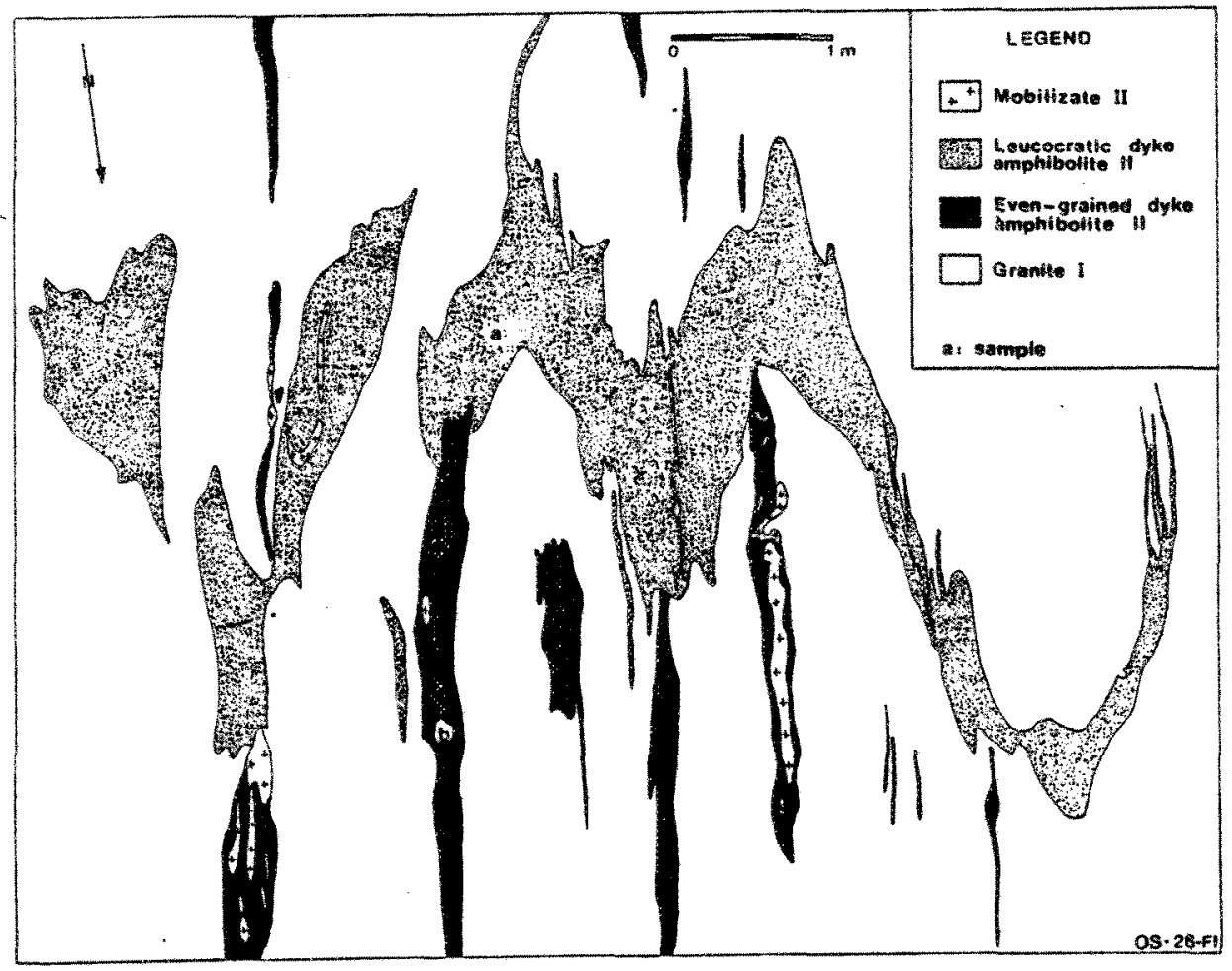

FIGURE 18.

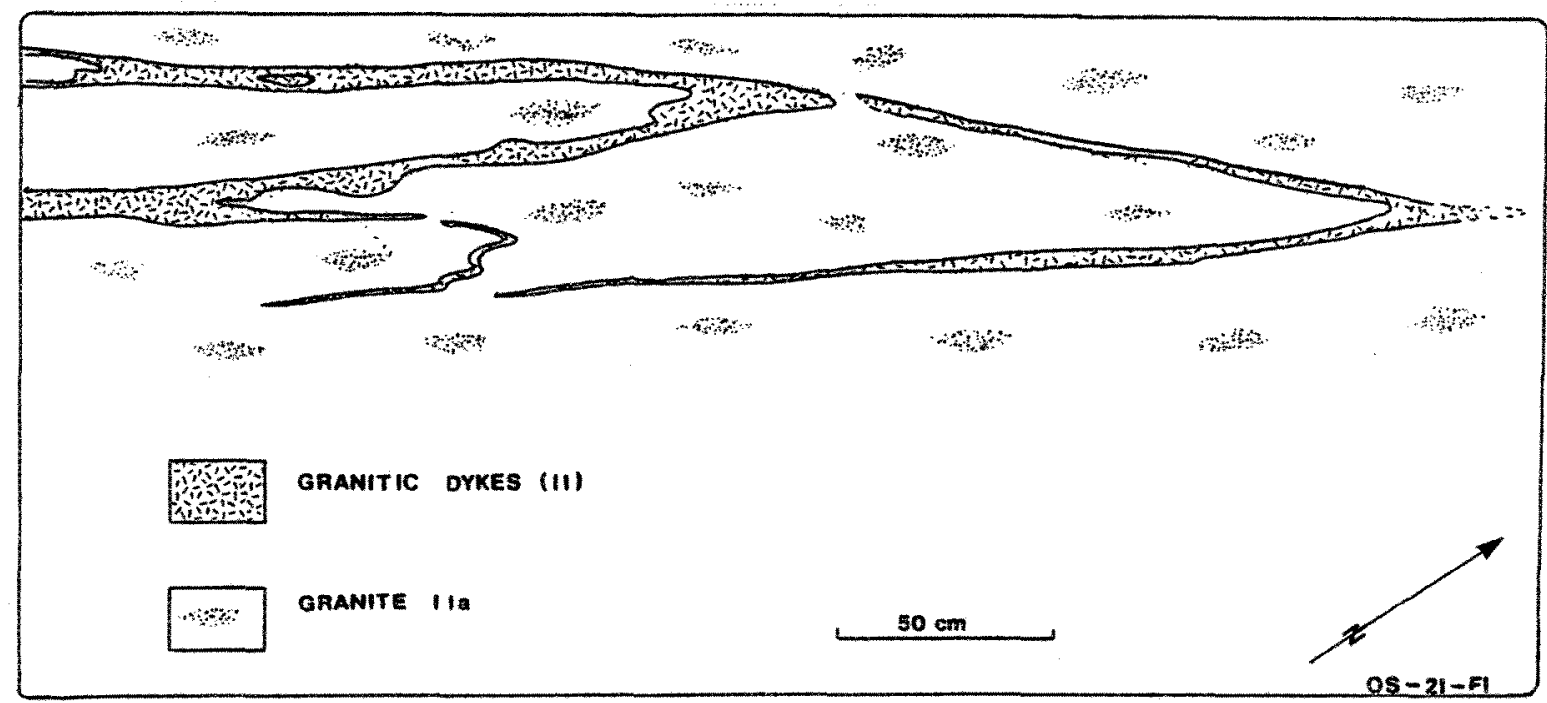

FIGURE 19. 


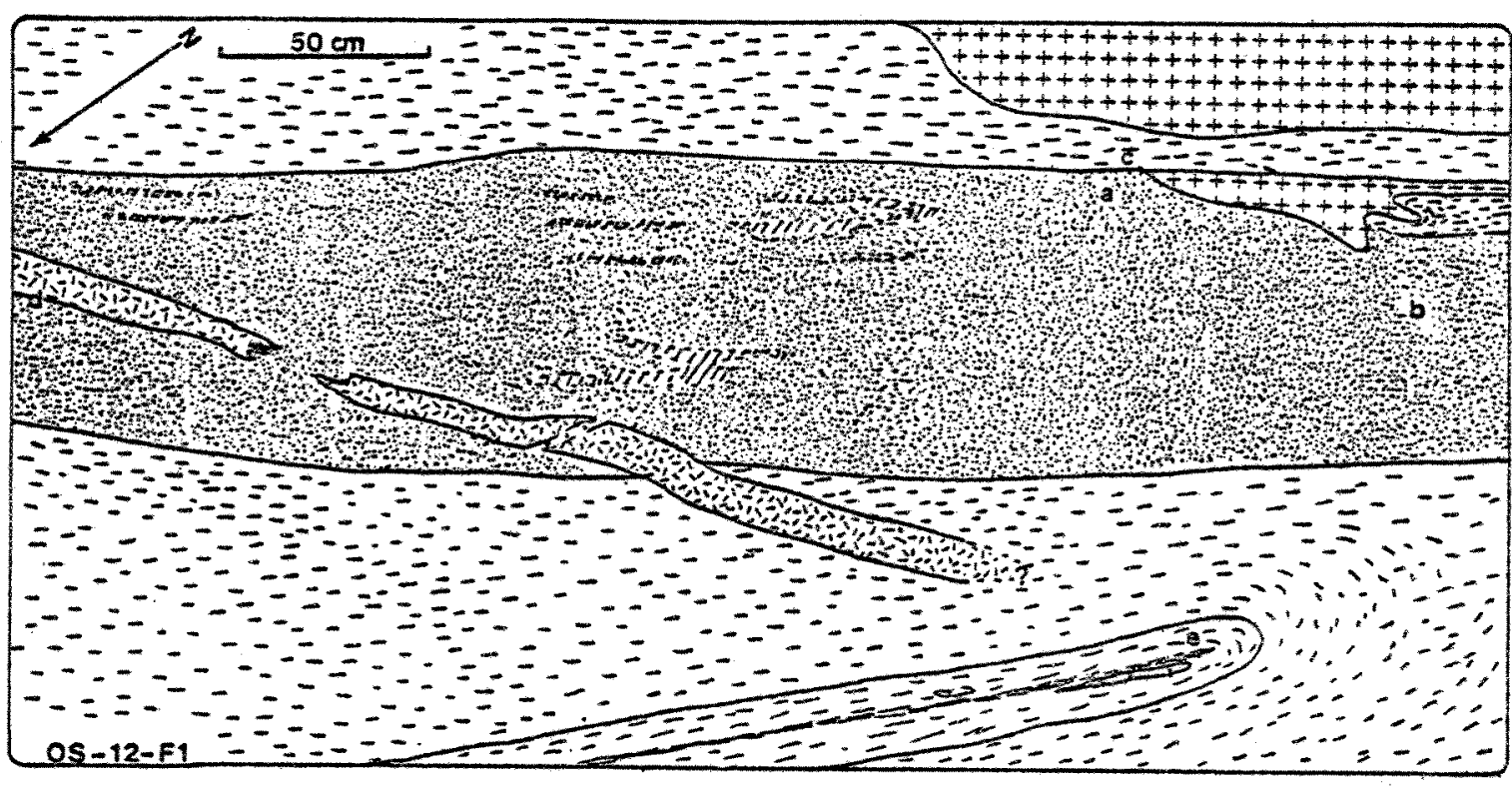

a : Sample location

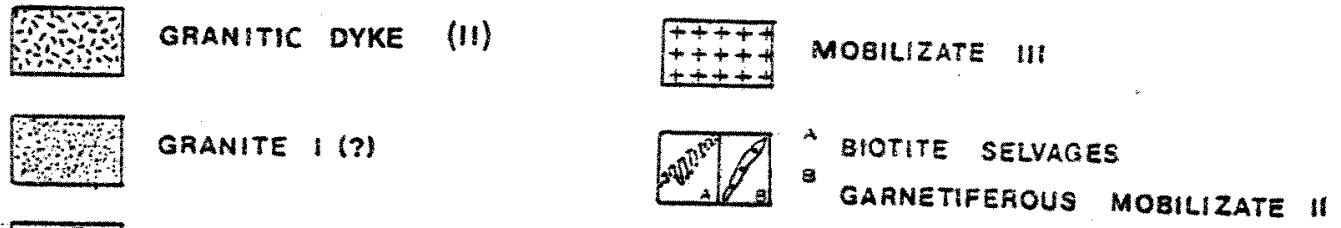

E=E- PARAGNEISS

FIGURE 20.

PLATE 12.

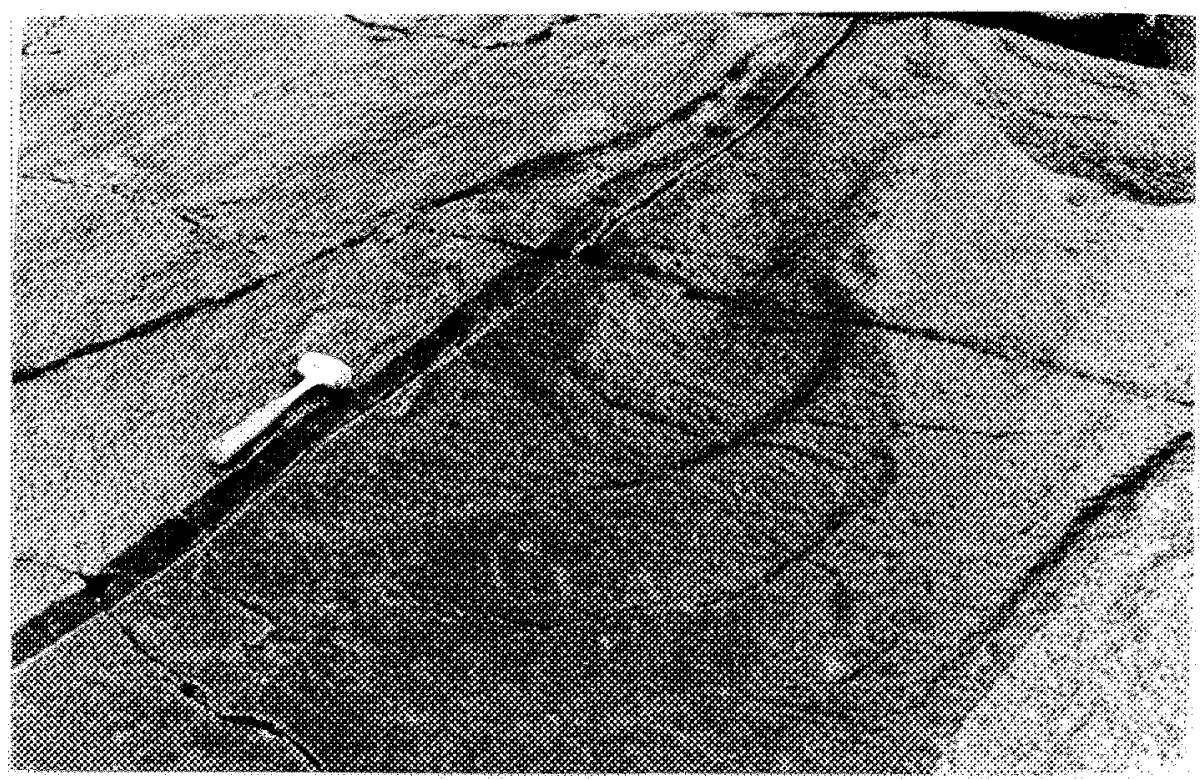




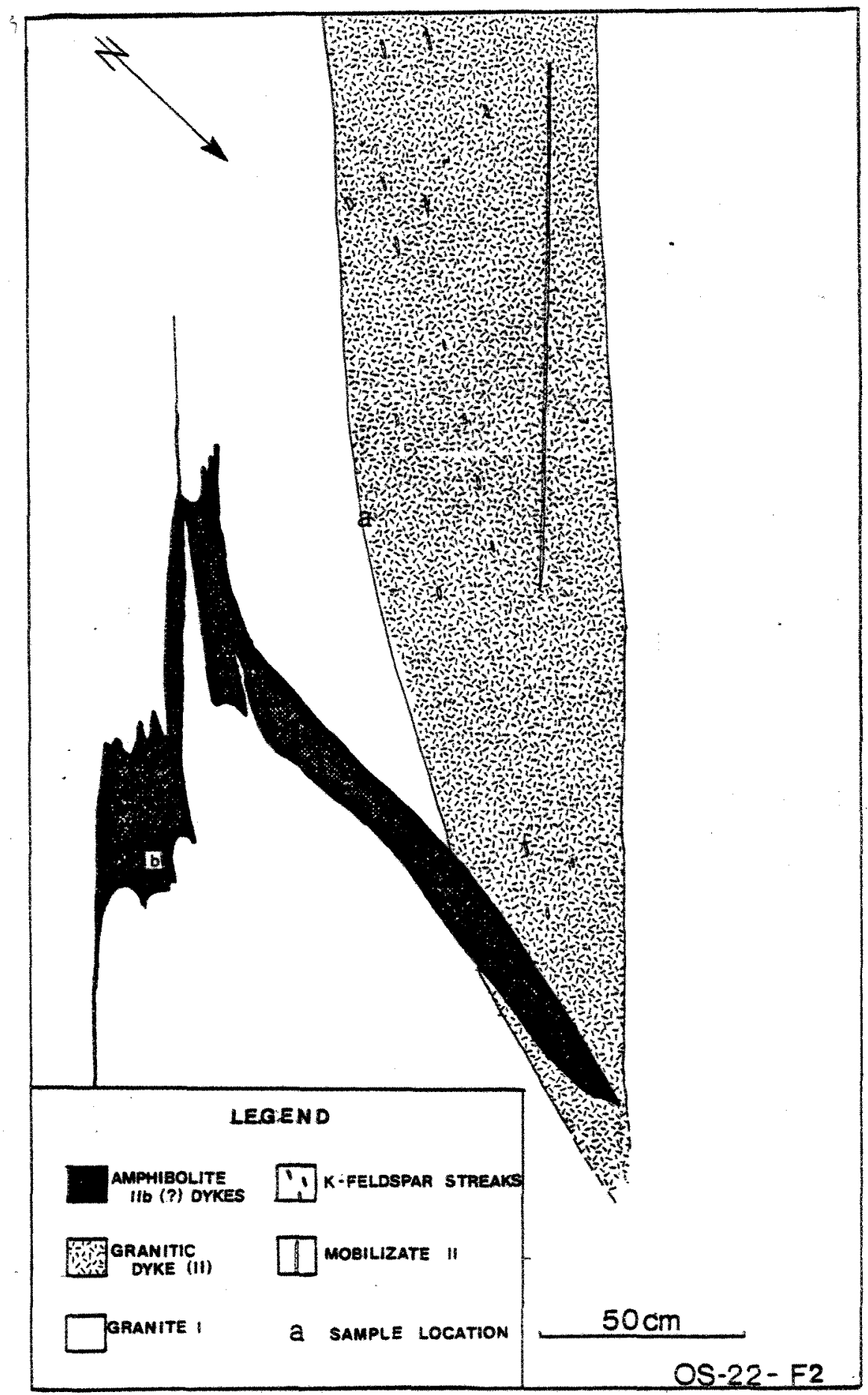

FIGURE 21. 


\section{PLATE 11 bareatures of dyke "amphibolites" are}

a. Perthitic microcline $(\mathrm{m})$ in groundmass of hornblende (after pyroxene)-phyric dyke amphibolite (IIa) Sampled from dyke depicted in Fig. 17: this thin dyke has been "granitized" by the adjacent moblizate II material during migmatization. Thin section OCJ-F1b. X-nicols.

b. Typical even-grained amphibolite (IIb), with hornblende (medium grey, two cleavages) and biotite (pale grey, basal cleavage) 'defining S2a schistosity. Thin section ON-4-2 (i). Plane polarized light.

c. Plagiociase-phyric variety of dyke amphibolite IIb. Note groundmass hornblende and plagioclase wrapping about the phenocryst aggregate. The phenocrystic aggrexate is heavily sericitized. Thin section OS-3-Fla. Plane polarized light. Bar: $1 \mathrm{~cm}$.

d. Poikiloblastic garnet (gt) forming in dyke amphibolite IIb near contact with garnetiferous biotite-sillimanite paradneiss. Sillimanite (white, fibrous) is enclosed in the garnet as are pale green patches (zrey in photo) consisting of serpentinized and biotitized former hornblendes, with opaques, carbonate and ouartz (?) as residues of the transformation. The garnetiferous marginal zone of the dyke, contacting the paragneiss, is biotitized: the hornblende:biotite ratio reaches a maximum toward the non-garnetiferous dyke centre. Thin section $0 N-3-2$. X-nicols.

e. Dioritic dyke (IIc), with biotite (medium frey, basal cleavage), clinopyroxene (dark grey, irregular cleaveges), and opaques in a plagioclase-quartz rich groundmass. Thin section $0 S-26-F l a$.

f.(i) Dioritic dyke showing parallelism of biotite schistosity and trondh jemitic leucosome (right, coarse grained). Note slight enrichment of mafic minerals at the interface between the two components (melanosome?). This schistosity (S2a) is axial planar to the F2a-folded dyke (Fig. 18). Thin section CS-26-Fla. Plane polarized light.

$f$ (ii) Detail of "melanosome" section shown in f.(i). Biotite (b), opaque $(0)$. 

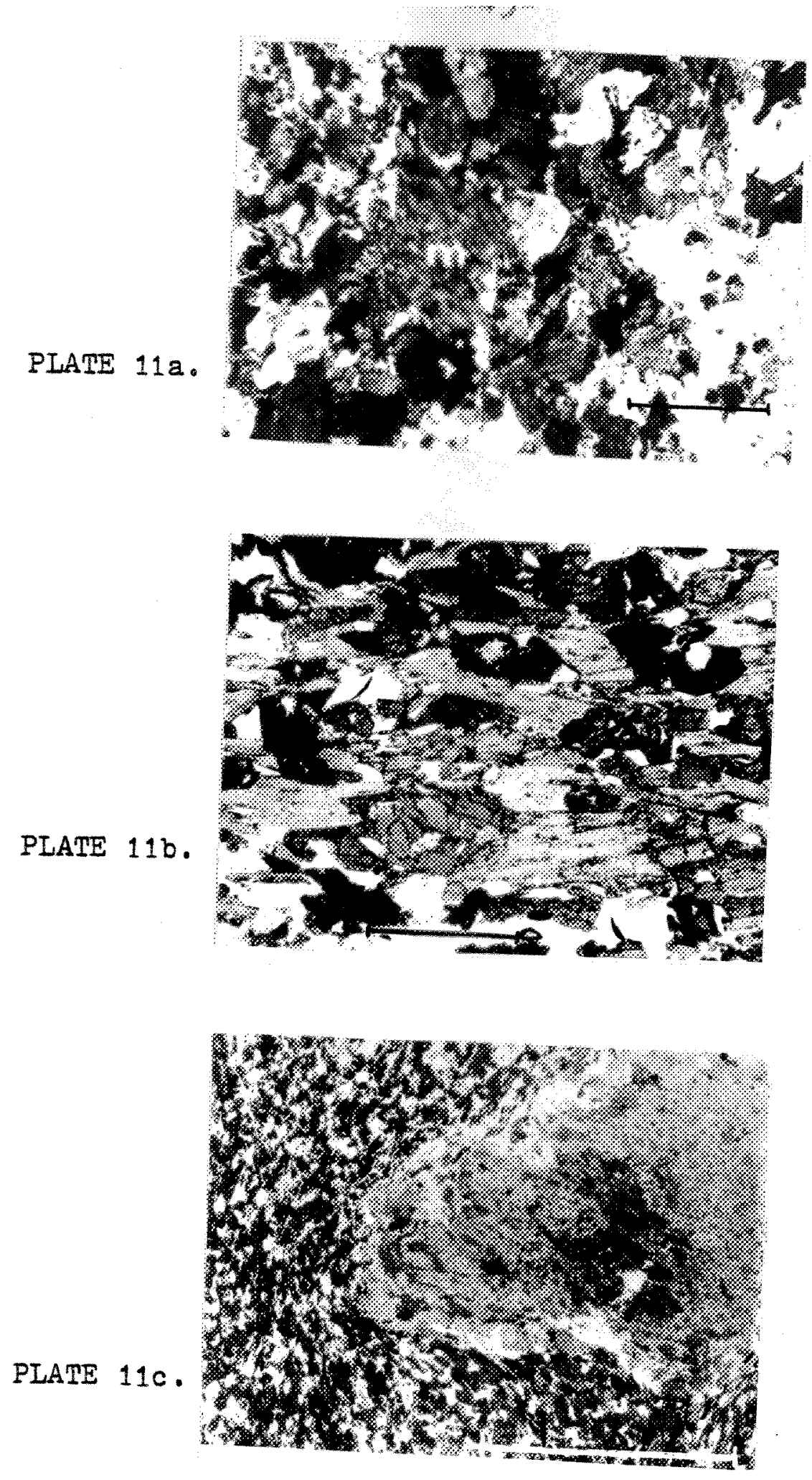


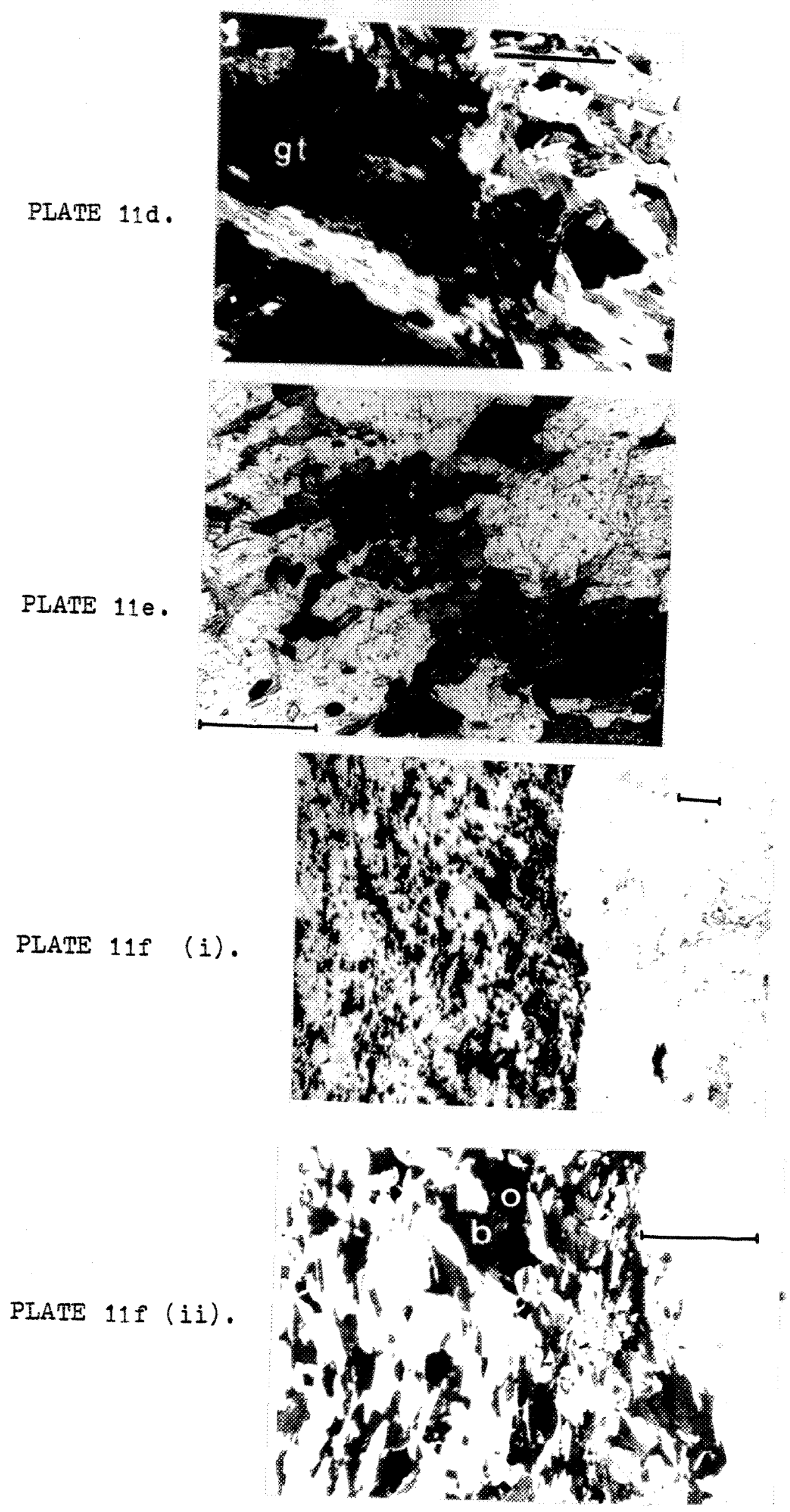


lesser plagioclase $(-20 \%)$. Mefic minerals total about $5 \%$, consisting of biotite and relict hornblende, altering to carbonate and opaques.

3-Rocks or Age Group III

Rocks postdating migmatization IIb and deformation IIc (Table i) are poorly represented within the study area. Rocks represented on Fig. 2 as "Eranite III" consist of unfoliated, mecium grained, pink biotite leucogranites and buff biotite leucotrondhjerites, which may be related to polyphase mobilizate III pegmatite injection. As such, these "granitic" rocks may not be correlated with syenitic granites and augengneisses outcropping to the west, near Chicoutimi (Fig. 1), as described by Dimroth et al (1980).

Figure 22 shows a relatively large wass of granite II intruding concordant amphibolite. The granite III here is even-grained (2-4 III), containing about 60\% potash feldspar (microcline), -25\% quartz, -124 plagioclase, and 34 randonly distributed biotite flakes. Plagioclase-quartz rich (trondjemitic) mobilizate III pepmatite dykes follow the contact between the granite and host concordant amphibolite (Fig. 22), dewonstrating that the granite antedates this particular phase of pegmatite injection.

Another variety of granite III outcrops at OS-14. The rock, as in the previous case, is even-grained $(2-4 \mathrm{~mm})$, but has a buff green fresh surface, and contains about 75\% plagioclase, -20\% quartz, -3\% magnetite, and about 1: biotite, and only trace amounts of potash feldspar.

Consequently, these "granite III" rocks are conpositionaliy identical to the range of granitic-trondhjemitic pegmatite dykes found within the study area, differing only in grain size and texture. A 
detailed account of the petrography, morphology, and mode of occurrence of mobilizate III pegmatites will be presented in section IV. It will be noted here, however, that pegmatite compositions vary between granitic (potash feldspar-quartz rich) to trondhjemitic (plagioclase-quartz rich) end members. The pegmatites are always leucocratic, containing $<5 \%$ mafic minerals, chiefly biotite and/or hornblende, in varying stages of alteration. Locally, the pegmatites also may contain up to about $30 \%$ magnetite (ex. Plate 14). The compositional similarity between the pegmatites and those rocks mapped as "granite III" indicate that these units are genetically linked, textural differences possibly resulting from higher vapour pressures and volatile concentrations present in the case of the pegmatites. 
FIGURE 22.

Pink, even grained biotite-bearing "granite III" intruding concordant amphibolite. The granite III antedates injection of thin trondhjemitic mobilizate III veins. Note the thin, discordant offshoot of an amphibolite Ila (amphibole-phyric) dyke in left-centre of the figure. 


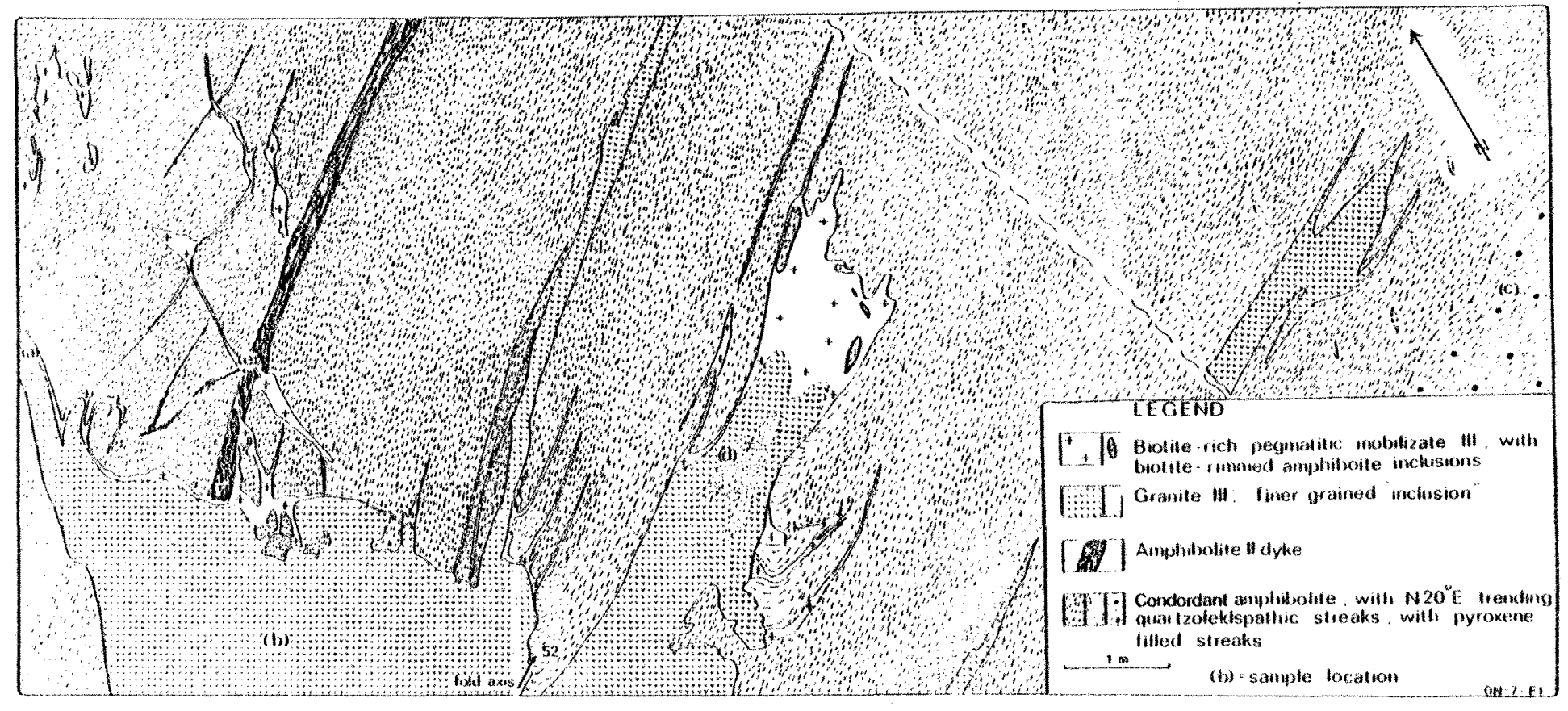

FIGURE 22. 


\section{MIGMATITES}

A. NOMENCLATURE

When Sederholm first defined migmatites as follows:

"For the gneisses here in question, characteristic of which are two elements of different genetic value, one a schistose sediment or foliated eruptive, the other, either formed by the resolution of material like the first or by injection from without, the author proposes the name of migmatites: the position of this rock being intermediate between eruptive rocks proper, and crystalline schists of sedimentary or of eruptive origin" (Sederholm, 1907, p. 110)

he provided the geological community at the outset with a definition fraught with genetic implications. Sederholm himself preferred a mechanism operating by "injection from without", although his "ichors" were not true magmas, being rather "things showing gradations between an aqueous solution and a very diluted magma, eventualiy also a magma containing much water in a gaseous state" (Sederholm, 1907, p. 89), thus including metasomatic fluids as well as igneous melts.

In an effort to remove many of the genetic implications inherent in the contemporary terminology, Scheumann (1936) introduced a "non-genetic" nomenclature. Even this attempt was compromised to a certain degree: Scheumann's term "metatect", still in common use to describe newly formed leucocratic material in migmatites, is derived from the Greek "tektos"-melt, thereby siding Scheumann with Sederholm.

K.R. Mehnert (1968) has provided a systematic nomenclature widely used in describing the morphology and mechanism of migmatites and migmatization processes. Migmatites are megascopically 
composite rocks, "consisting of two or more petrographically different parts, one is the country rock in a more or less metamorphic stage, the other is of pegmatitic, aplitic, granitic, or generally plutonic appearance" (Mehnert, 1968, p. 355). Following Mehnert's (1968) classification, a migmatite will generally consist of a paleosome (country rock) and a neosome (newly formed, often mobile, rock portion). The neosome may consist of a leucocratic quartzofeldspathic portion (Ieucosome) which is frequently bordered by a mafic melanosome, also variously referred to in the literature as a mafic selvage (selvedge), or an immobile restite.

Parts of gneissic rocks with leucocratic portions will here be referred to as leucocratic "segregations", as a general term. More specific terms will be used where appropriate (ex. veins, pods, streaks, flecks). Leucocratic segregations will be considered to be "mobilizates", a "petrogenetically neutral term" (Mehnert, 1968, p. 356), rather than "metatects", which implies a process of metatexis, that is, "partial, differential, or selective anatexis of the low-melting components of a rock" (Mehnert, 1968, p. 355). This is done in keeping with the goal of avoiding genetic implications in describing the mesoscopic and microscopic features of the leucocratic segregations seen in the migmatitic gneisses in the study area. Genetic considerations will be presented as a Discussion (Section V), conclusions coupling mesoscopic and microscopic observations and data, comprising the bulk of the text of the present work.

\section{B. POSSIBLE ORIGINS OF MIGMATITES}

1-Historical Background

Despite the fact that migmatites have been the subject of considerable geological investigation for over one hundred years, the origin of this widespread lithology remains controversial. This reflects the fact that different geologically-plausible mechanisms 
FIGURE 23.

vorphology of the necsome components of a migmatitic gneiss. 


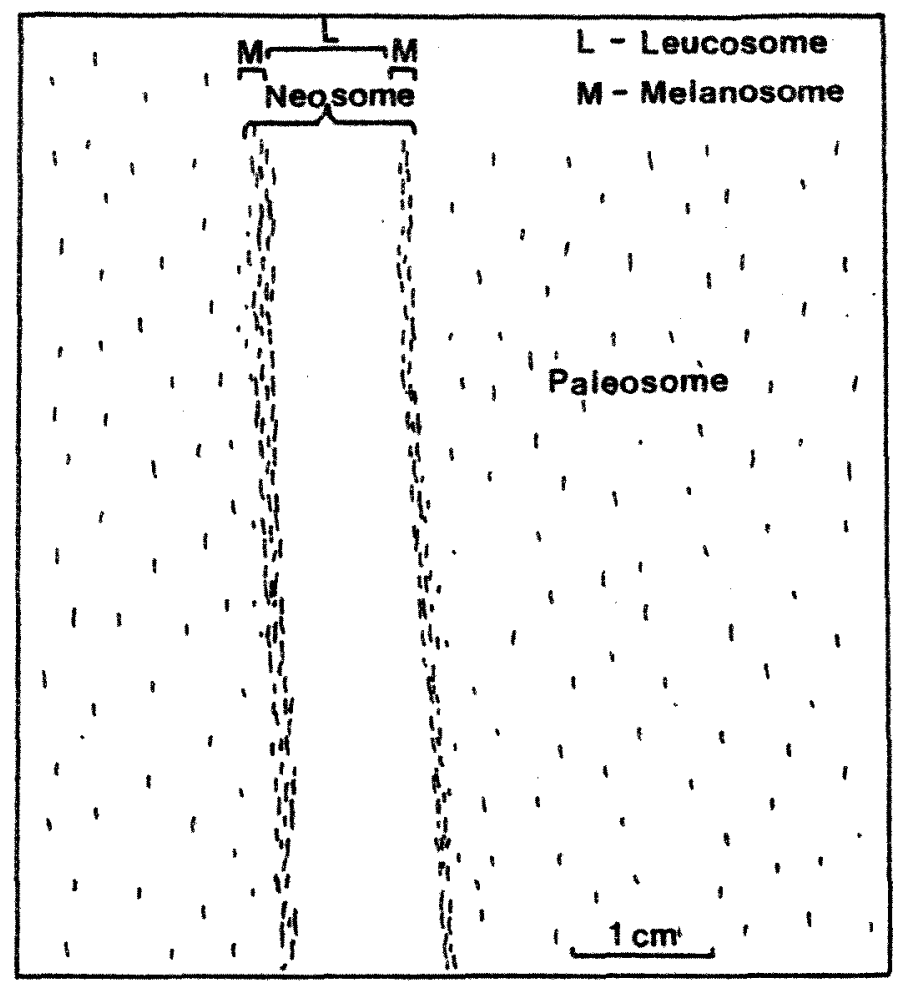

FIGURE 23. 
of migmatization may produce morphologically and compositionally similar types of migmatites. As such, identical phenomena observed in migmatitic terranes have been interpreted by different geologists as being the products of markedly different migmatization processes.

The controversy concerning the origin of migmatites was well established early in this century, following systematic and detailed studies by J.J. Sederholm and P.J. Holmquist in Fennoscandia, Sederholm, who coined much of the terminology still used in describing migmatites, maintained that the leucocratic veins representing the "igneous" portion of migmatites were emplaced from deep, external sources as a melt (Sederholm, 1967 reprint). Holmquist, on the other hand, believed that the host rocks (paleosomes) were the source of the leucosomes, the vein material segregating either by the process of lateral secretion or by in situ partial melting. With regard to the latter case, Holmquist imagined deep crustal zones of sufficiently high pressure and temperature to initiate "a real fusion of the most fusible rock masses" (Holmquist, 1920 , p. 210). The process of lateral secretion is now referred to as metamorphic segregation or differentiation, and present-day controversy involving possible processes of migmatization focuseson the merits of metamorphic differentiation versus anatexis as the most likely migmatization mechanisms.

Thus, two early schools of thought were established; one wherein igneous injection from an external source emplaced molten felsic material in the migmatitic terrane, the other supporting a more-or-less closed system, where vein material segregates by metamorphic differentiation or by in situ partial melting.

The relationship between some granitic massifs and the formation of migmatites became apparent during Barrow's (1893) studies in Scotland. Here, gradational changes of pelitic country rocks from slates, phyllites and schists through to granitic gneisses approaching a central granitic massif were interpreted as being the result of the thermometamorphism of the country rock of the granitic 
intrusion, the migmatitic nature of the gneisses resulting from the introduction of residual fluids from the granite in late stages of crystalization. As such, the important of field relationships of migmatites with stratigraphically equivalent country rocks was established, as later emphasized by Read (1957).

Read (1957), observing uninterrupted stratigraphic units passing directly into granitic rocks without an intermediate magmatic stage, interpreted these relations as being the products of metasomatic fluids emanating from the granite. Only sediments approximating the composition of a granite were so-transformed; limestones, quartzites, amphibolites, and other lithologies compositionally dissimilar to granites resisted granitization. These notions represent a fourth possible mechanism of migmatization: external metasomatism, which falls alongside Sederholm's igneous injection hypothesis as involving an open system

Exp imental work in the last few decades has quantified possible conditions of crustal anatexis, as envisioned by Holmquist (1920). Tuttle and Bowen (1958) experimentally established that melts of granitic composition may be generated by regional metamorphic grade PT conditions in the presence of water, by the process of anatexis. The resulting granitic melt has a distinctive "minimum melt composition' falling near the cotectic of the synthetic system albite-orthoclase-quartz-(water) (Tuttle and Bowen, 1958). This, along with Winkler's and Winkler and von Platen's (c.f. Winkler, 1974) work on natural geosynclinal sediments (clays, greywackes), and other partial melting experiments on gneisses by Steunl (1962), Mehnert et al (1973) and Busch et al (1974), indicate that partial fusion is initiated at temperatures between 600 and 750 $\mathrm{C}$, at $\mathrm{P}-\mathrm{H} 2 \mathrm{O}$ from 2 to $10 \mathrm{~kb}$. These conditions correspond, for instance, with crustal depths in the order of $20 \mathrm{~km}$ (Iithostatic pressure approximately $5 \mathrm{~kb}$ ) given a typical geothermal gradient of $30 \mathrm{c} / \mathrm{km}$, (Mehnert, 1968), the depth varying with geothermal gradient accordingly. Experimental studies have shown that Tuttle and Bowen's (1958) synthetic system is incomplete; natural systems 
contain plagioclase as an important constituent. Consequently, the quaternary system anorthite - albite - orthoclase - quartz - (water) more closely approximates natural rocks.

\section{2-Mechanisms of Migmatization}

Confronted with the problem of interpreting the genesis of a migmatite terrane, the researcher must seek reliable criteria or observations indicative of the fundamental physical-chemical conditions operative during the migmatization process(es). Is the migmatite a product of in-situ differentiation and/or has any material been introduced or removed from the system? That is, are we dealing with an open or a closed system? Have the "magmatic" -appearing portions (leucosomes) of the migmatite ever been fluid? Resolution of these basic problems will identify the fundamental migmatization process(es), according to those summarized in Table 3 . It must be emphasised at the outset that unique, unequivocal definition of the process(es) responsible for the migmatization of a given area may not be possible; different mechanisms may develop similar phenomena.

Before discussing possible criteria for distinguishing between the migmatization process outlined in Table 3, it is advisable to briefly review some of the parameters and conditions controlling each process.

Igneous injection has rarely been described as the dominant or sole mechanism operative in a migmatitic terrane, insofar as igneous intrusions rarely impart a wholesale migmatitic aspect to their host rocks. A few examples of this, however, are described in the literature, for example, certain plutons in the Donegal district of northwestern Eire (Pitcher and Berger, 1972). The only conditions necessary for igneous activity to occur are, firstly, a source of magma, which may be of any composition, and secondly a mechanism of emplacement. It is the nature of the second condition that 
TABLE 3: Mechanisms of migmatization.

Material introduced from outside system?

PROCESS

Melt Phase

Yes: Igneous

Present?
Yes: Open System

Igneous injection

External metasomatism
No: Closed System

Anatexis

Metamorphic differentiation

(after White, 1966; Misch, 1968; and Yardley, 1978)

Note: Given the scale dependence of the concept of an open vs closed system,

we consider a closed system to involve migration of migatitic riuids etc

within an outcrop scale, thus allowing for migrant anatectic mobilizates,

involve the introduction/migration of migmatitic fluids, etc. on a larger-than-outcrop scale. 
determines whether igneous injection will yield rocks of migmatitic character. Magmas which permeate and brecciate country rocks during intrusion would contain abundant xenoliths, yielding a rock assemblage with an agmatitic aspect.

External metasomatism is a special case of hydrothermal activity, wherein "chemical potentials"(and hence fluid composition) are controlled externally relative to an initially homogeneous layer, and removal and/or precipitation of material occurs, resulting in a change in the bulk composition of the layer" (Yardley, 1978, p. 943). Ionic transport under anhydrous conditions is so limited in extent that migmatization in the absence of fluids is considered to be insignificant. As such, metasomatism invariably involves on transport through pore fluids in rocks. Transport of ions may occur via diffusion through a static pore fluid (diffusion metasomatism) or by the bulk flow of pore fluids (infiltration metasomatism). Regardless of the mechanism of ion transport, the important factor defining "external" metascmatism as a process of migmatization is the introduction of certain ions, and probable concomitant removal of other ions, through or by the pore fluid into a certain layer, demonstrably changing that layer's bulk composition-in effect, migmatizing it. The migmatizing effect results from the fact that the mobile ions present in the pore fluid (eg. $\mathrm{K}, \mathrm{Na}, \mathrm{Ca}, \mathrm{Si}, \mathrm{Al}$ ) tend to be those which segregate into veins, forming leucocratic layers. Where diffusion metasomatism on a small scale occurs, these leucocratic layers will have margins depleted in vein minerals (Yardley, 1975), although proponents of a partial melting mechanism ascribe an anatectic process to this feature. Diffusion metasomatism operative within compositionally heterogeneous rock sequences may, as such, be considered to represent an open system, on a layer to layer scale (eg infiltration of ions from one layer to another), but a more or less closed system within the context of the layered unit as a whole. From this standpoint, the migmatization process trends toward homogenization of the layered sequence. Where ions are transported into the system from an external source, the layered sequence will show bulk 
chemical compositional changes on all scales. In this case, as in the former case, leucocratic veins may develop, forming a migmatitic aspect, following fracture systems or foliations (eg. schistosity) in the unit. Bydraulic fracturing by the hydrothermal solutions way induce segregation of leucocratic veining (Yardley, 1975).

Anatexis refers to the partial melting (fusion) of rock material. The degree of partial melting may, depending upon PTX conditions and upon the material being fused, vary widely. Metatexites are rocks formed by incipient degrees of partial melting (metatexis), the partial melt fraction tending to segregate into thin veins and other morphologies, giving the rock the banded appearance so typical of migmatites. Diatexites are formed from rocks having undergone an advanced degree of melting (diatexis). The resulting rock has a diffuse appearance (ex. schlieric or nebulitic texture; Mehnert, 1968), wherein originally molten and unmolten portions may no longer be distinguished (Busch et al, 1974; Winkler, 19.79).

Anatexis commences along the contacts between mineral aggregates. Leucocratic minerals tend to have lower melting points than ferromagnesians, consequently melting commences at triple points of quartz-plagioclase-potash feldspar, along quartz-plagioclase and ouartz-potash feldspar boundaries, and along contacts betweenidentical minerals (Molen and Paterson, 1979). In experimental melting of natural rock samples, quenching of samples exposed to PTX conditions initiating anatexis demonstrates that the partial melt forms consistantig thin films (15-20 microns thick) along the contacts described above (Mehnert et al, 1973). In the absence of water, initiation of partial melting requires prohibitively high temperatures, unlikely to be represented in the deep crust of Earth. Although aqueous pore fluids are present in substantial quantities in subducting geosynclinal sediments, these luids are largely absent in deep seated continental gneisses. However, partial melting may nevertheless be triggered by dehydration reactions involving hydrous ferromagnesian minerals 
(Brown and Fyfe, 1970, 1972). Partial melting may yield rocks of migmatitic character since the melt component tends to migrate into low pressure (dilational) zones present in the deformational/anatectic environment. The geometry of these dilation zones controls the morphology of the leucosome, also controlled by the degree of partial melting. Progressively advanced stages of partial melting systematically alter the composition of the melt phase, approaching the composition of the rock being melted.

3-Possible Criteria for Distinguishing Migmatization Mechanisms

Concise definition of three properties may be sufficient to completely describe a migmatite; morphological, mineralogical, and chemical properties.

Morphological properties focus on the mesoscopic field aspects of the various components of a migmatite. Since it is the origin of the leucocratic segregations (neosome) of the migmatite that is most problematical, aspects of leucosome field occurrences must be fully documented, in relation to a melanosome (where present), the paleosome, and to other leucocratic segregations, and to structural features in the migmatite. In the initial perusal of a migmatitic terrane, the "paleosome" should be considered to be merely the host rock of the leucocratic segregations, since, at the outset, it is not known if the migmatitiztion process operated under open or closed conditions. However, the presence of a melanosome bordering leucosomes proves beyond doubt that the system was in large part closed.

A fundamental property of leucocratic mobilizates is their preferential localization in structural dilation zones. Although planar leucosome veins concordant to paleosome foliation may not show signs of having had any fundamental control on their localization, apart from host rock foliation, petrographically similar material in the same outcrop may be segregated into obvious dilation zones. Some of these structural traps (summarized in Fig. 
23) include interboudin infilings, localization in dilational fold hinges and flexural zones, the infilling of brecciated layers, and of joints, and the segregation of neosome material in down-gradient pressure shadows in the terminal regions of inclusions in the paleosome. In the latter case, the neosome may surround or partiy surround the inclusion if bodily rotation has occurred during leucosome genesis (Ramberg, 1956). Another typical leucosome occurrence - an enigmatic one to the uninitiated-is as veins seen cross-cutting dykes in the paleosome. This is the so-called "Sederhoin effect" (Sederholm, 1967, p. 325), which emphasizes the mobile nature of leucosomes in migmatites. Given these relations, chronological aspects of migmatization may also be defined.

Although these and other field occurrences of neosome material have been documented in different migmatite terranes of all ages throughout the world, their interpretation has varied considerably. Differences of opinion may stem from different interpretation as to the effect the different rheological properties on neosome and paleosome material will have on the localization of the neosome, and the formation of structures therein. This interpretation is linked directly to the physical state of the neosome during its development and segregation. For example, Ramberg (1956) eschews the possibility that leucocratic veins studied in west Greenland migmatites were ever in a fluid (ex. molten) state, citing structural evidence that certain features such as vein pinch and swell occur only along conformable competent layers in response to tensional dragging due to plastic flowage in the adjacent incompetent host rocks. Pinching in the vein develops locally because the competent vein will not yield homogeneously along its entire length by recrystallization flowage (Ramberg, 1956). Since pinch and swell will only occur along veins with less competent host rocks, the vein material could not have been fluid at the time of formation of this structure. Following a similar arguement, Escher (1966) concludes that pinch and swell structures in leucosomes in upper amphibolite grade gneisses in the Nanortalik area, south Greenland, formed by pushing adjacent gneissic host rocks aside 
plastically. These structures, interpreted as forming while the leucosome grew in the solid state, the continuity of paleosome layering on either side of pegmatoid veins, compositional similarity of paleosome and vein material, the non-dislocation of paleosome "inclusions" in leucosomes, feldspar porphyroblastic growth in the paleosome adjacent to leucosomes, and the amphibolite facies mineral assemblages (eg. $(600$ C) of leucosomes lead Escher (1966) to suggest a migmatization process of migration and/or in situ secretion of quartzofeldspathic material in slip planes and joints. This material grew by replacement and by pushing aside the host and earlier formed veins. Swelling in boudinaged veins indicates that locally more volume has been added than replaced. Migration of material into the system is indicated leucsome volumes exceeding that expected to have been generated from paleosomes. Granulite facies rocks in the area have been "degranitized", consequently these rocks provided $\mathrm{Si}, \mathrm{K}, \mathrm{Na}, \mathrm{Al}$, and $\mathrm{Ca}$ for the migmatization of the amphibolite facies rocks. Consequently, leucosome-paleosome relations and comparable mineral assemblages indicative of subanatectic PT conditions suggest migmatization by external metasomatism and metamorphic differentiation. Similarly, Ramberg (1956) argues for solid state growth of leucocratic material in interboudin zones. In Ramberg's study area, interboudin interstices are never partly filled by a void, and these interstices would invariably be filled not only by leucocratic material, but also by the adjacent incompetent gneiss, host to the competent layer being boudinaged, if the dilational site had ever been "empty". Despite Ramberg's (1966) and Escher's (1966) eloquent arguments, one might also imagine that pinch and swell structures in some veins were formed after consolidation of molten leucocratic material, and that interboudin dilation zones are never, or are rarely, "empty" rather being downgradient, low pressure zones, into which fluids, including melts and metasomatic fluids, migrate, later consolidating to form ieucocratic, interboudin material. Furthermore, dehydration reactions occurring in upper amphibolite grade conditions may initiate anatexis (Brown and Fyfe, 1970). 
Yardiey (1978, Table 2) recognizes different morphological varieties of leucosomes in migmatites of different origins. Since the four principal proposed mechanisms of migmatization differ according to the presence of a closed versus an open system, and according to an igneous versus a hydrothermal origin for leucosomes, the mechanism of miguatization will have distinctive physico-chemical properties, which ultimately control the morphology, including volumes, of resulting mobilizates. For igneous mechanisms, rotation of paleosome inclusions in the leucosome is possible. In injected igneous veins rotation of these inclusions likely, depending upon the mechanism (eg passive vs forceful) of emplacement. On the other hand, rotation of inclusions in anatectic leucosomes is likely only where sufficiently large volumes of melt have been generated to extensively agmatize (Mehnert, 1968) the paleosome. This follows from the fact that intruded veins need only be molten as they are individually intruded, whereas anatexis will occur almost simultaneously in a given area in rocks of similar composition and water content. Thus, all leucosomes so-generated are molten at the same time, thereby mechanically weakening the host rock, encouraging agratization. Before such a conclusion may be reached, however, contrary evidence should be sought: cross-cutting veins of similar petrography and morphology likely formed during the same anatectic (?) episode, but nevertheless demonstrate that not all leucosomes were simultaneously fluid.

Non-igneous leucocratic segregations would not be expected to contain rotated paleosome inclusions. During hycrothermai processes, only small amounts of migmatizing fluids need be present at any given time (Yardiey, 1978), therefore extensive and closely spaced veining may occur without mechanically weakening the paleosome. However, as noted above, the volume of melt generated by anatexis varies widely. Furthermore, not all anatectic veins generated by the same period of partial melting need have been simultaneously fluid, as evidenced by cross-cutting leucocratic veins (Fig. 17). Thus, these criteria may be reliable only in specific cases, and where supported by other observations. 
From the foregoing, it is clear that mesoscopic fleld occurrences of neosome material are related to structural features in the paleosome. The development of leucosome morphologies may thus be related to particular deformational episodes; whether particular morphologies develop prior to, during, or following a deformation is an open question, whose solution is founded in the researcher's interpretation not only of deformational features in and about the leucosome itself, but also according to his interpretation of the physical state (eg growth in the solid state, or precipitation from or consolidation of a fluid) of the leucosome at its time of development. This is perhaps best obtained from detailed examination of the mineralogy, textures, and compositions of leucosomes, and the relations of these to adjacent melanosomes and paleosome material, where present.

Mineralogical properties afford several criteria indicative of the physical state of the system at the time of neosome formation. Except for the case of trace elements, chemical criteria may be considered alongside mineralogical parameters. Reliable estimates of the bulk composition (major oxides) of leucosomes may be had by modal analysis, as well as by standard analytical techniques (Ashworth, 1976). Similarly, optical techniques may replace chemical analysis in determining individual solid solution mineral compositions, most importantly, that of plagioclase, and, to a lesser degree, the albite content of orthoclase.

Leucocratic segregations that are the products of anatexis should yield mineralogical and chemical characteristics in accordance with those predicted by experimental melting of natural and synthetic systems. Perhaps the most important of these is the quaternary system albite-anorthite-quartz-orthoclase-(water). Ideally, anatectic quartzofeldspathic segregations will have a compositiom falling near this system's cotectic, representing the granitic "minimum melting composition" (Winkler, 1979). Owing to the strong fractionation of the albite component of paleosome plagioclase into initial partial melts during anatexis, granitic 
leucosomes would be expected to have plagioclases in the order of 10 to $40 \%$ more albitic than that in the adjacent melanosome (Yardley, 1978). Tobschall (1971) reports anatectic migmatites from Beaume-Tales, Frances, having leucosome plagioclases of composition An 9-14, compared with more calcic (An 30-40) melanosome plagioclase. As such, the presence of relatively sodic leucosome plagioclase is a strong indication of an anatectic origin. Conversely, similar leucosome/melanosome plagioclase compositions indicate either a non-anatectic origin, or the subsolidus reequilibration of the leucosome with the adjacent melanosome (Yardley, 1978). Where leucosome/melanosome plagioclase compositions are similar, or are ambiguous, other criteria should be consulted when considering possible migmatization mechanisms. For example, Misch (1968) reports slight but consistent albite -enrichment in leucosome plagioclases in the Skagit Gneiss, Washington. However, he concludes that the migmatization process was one of metamorphic differentiation, with bulk compositional changes also indicating external metasomatism. Plagioclase compositions in the leucocratic Skagit gneiss show statistically close relationships to the schists and amphibolites from which they were derived; the gneiss plagioclases vary widely in composition, in accordance with the compositions of the plagioclase in their parent rock. A non-anatectic origin is also supported by the absence of basification of schist and amphibolite remnants, as would be expected due to the subtraction of leucocratic minerals, and the leucotrondhjemitic to quartz dioritic composition of the migmatitic gneisses, which are impoverished with respect to $\mathrm{K} 20$ compared with parent rocks. Within the skagit gneiss, some features may be entirely attributed to either metamorphic differentiation or metasomatic replacement, but in most cases both processes are indicated, with metasomatism being largely responsible for regional migmatization.

The significance of leucosome $\mathrm{K} 20$ content, chiefly represented by potash feldspar, is made apparent by experimental melting studies, in which it has been shown that anatectic leucosomes will 
contain significant quantities of potash feldspar even when derived from paleosomes relatively impoverished with respect to potassium. For example, if biotite is the sole potassium-bearing paleosome mineral, potash feldspar will nevertheless be generated during incipient melting due to the breakdown of biotite in the developing melanosome, leaving, as a residue, garnet or cordierite (Kilinc, 1972, Yardley, 1978). Leucosome potash feldspar will also form at the expense of potash feldspar in the developing melanosome, depleting the latter to near exhaustion (Ashworth, 1979; White, 1966). As such, quartz-plagioclase veins would not be expected to form from the partial melting of $\mathrm{K}$-mineral bearing paleosomes (Yardley, 1975; Amit and Eyal, 1976).

From this the importance of leucosome-melanosome relations is made apparent. While it is clear that the leucosome develops at the expense of melanosome material, whether this segregation of paleosome components occurs in the solid state, or in a partly fluid (molten) state is uncertain. Proponents of an anatectic mechanism consider the melanosome to represent refractory material (restite) which accumulates to form mafic seams bordering the segregating vein of mobile leucocratic melt. Supporters of hydrothermal processes believe that this segregation occurs in the solid state, possibly being initiated along primary compositional planes (bedding) or along planes of weakness, especially in ductile paleosome (Yardley, 1978). Metamorphic or metasomatic pore fluids provide the medium of transport, via ionic diffusion through a static fluid, or through the bulk flow of fluid. Hughes (1970) suggested that mafic selvages form along interfaces between rock with a silicate pore fluid formed during incipient partial melting, and rock with a hydrothermal pore fluid. The ubiquitous presence of melanosome seams bordering leucocratic veins in migmatites of different compositions, and of different metamorphic grades, indicates that these may form by different processes, consequently, in the absence of further information, especially a comparison of melanosome/leucosome plagioclase composition, the compositional complementary nature of quartzofeldspathic veins and their marginal mafic selvages does not, 
in itself, favour either an anatectic or hydrothermal mechanism. Neither does the absence of a melanosome necessarily favour an igneous injection origin. Rather, the absence of melanosomes, or melanosomes insufficiently thick to account for leucosome volume, indicates the mobility of anatectic melts, or, equally plausible, a combination of metamorphic differentiation (creating the selvage), with concomitant introduction of leucocratic material via external metasomatism. Large volumes of leucosomes also indicates an unspecified source in the paleosome, thus not all leucosome material is generated in the melanosome.

From the foregoing arguments, we are led to the inexorable conclusion that neither morphological nor mineralogical criteria furnish ironclad methods for distinguishing migmatization processes. A particular process may be preferred, not so much for its own merits, but insofar as another process, or processes, may be excluded from the realm of possiblity, based on the evidence at hand. Although summarizing the typical features of different genetic types of migmatites is of some use in classifying migmatization mechanisms (c.f. Yardley, 1978, Table 2), determination of the genetic process(es) responsible for the migmatization in a given area is best accomplished by a process of exclusion. This may be undertaken by considering which features may determine if a) the migmatization process was isochemical; b) if the leucosome material crystallized from a melt. The process may be systematically employed by noting the presence/ absence of these features. The method is presented in flow-chart format in Table 4. Note that distinction of an open versus a closed environment of migmatization is usually a goal of research, not a starting point. However, the scale dependance of the concept provides a certain leeway in interpretation. Obvious evidence supporting a closed system (eg. melanosome-leucocome relations) permits classification of leucocratic segregations in the field, pointing toward an allochthonous or autochthonous origin. Evidence for metasomatism may be clear cut, as in the case of quartz-rich veins in quartz-poor paleosomes, or nebulous, in which case bulk chemical analyses may be required. 
By comparing the result obtained from Table 4 with PT conditions indicated by mineral assemblages, the adequacy of the method may be tested. For example, leucosomes interpreted as being the products of anatexis should be restricted to upper amphibolite or granulite metamorphic facies asemblages. 
TABLE 4 .

Petrographic indicators of migmatization processes, in flow-chart format. The various paleosome-neosome relations seen in the old Gneiss Complex are fully described by the features/mechanisms indicated here. By comparing the result obtained from Table 4 with PT conditions indicated by mineral assemblages, the adequacy of this method may be independently tested. For example, leucosomes interpreted as being the products of anatexis should be restricted to upper amphibolite or granulite metamorphic facies assemblages. 
Mineralogy

leucosome

- mineralogy host rock?
Leucosome plag.

more sodic than

melanosome plag.?
PROCESS present?

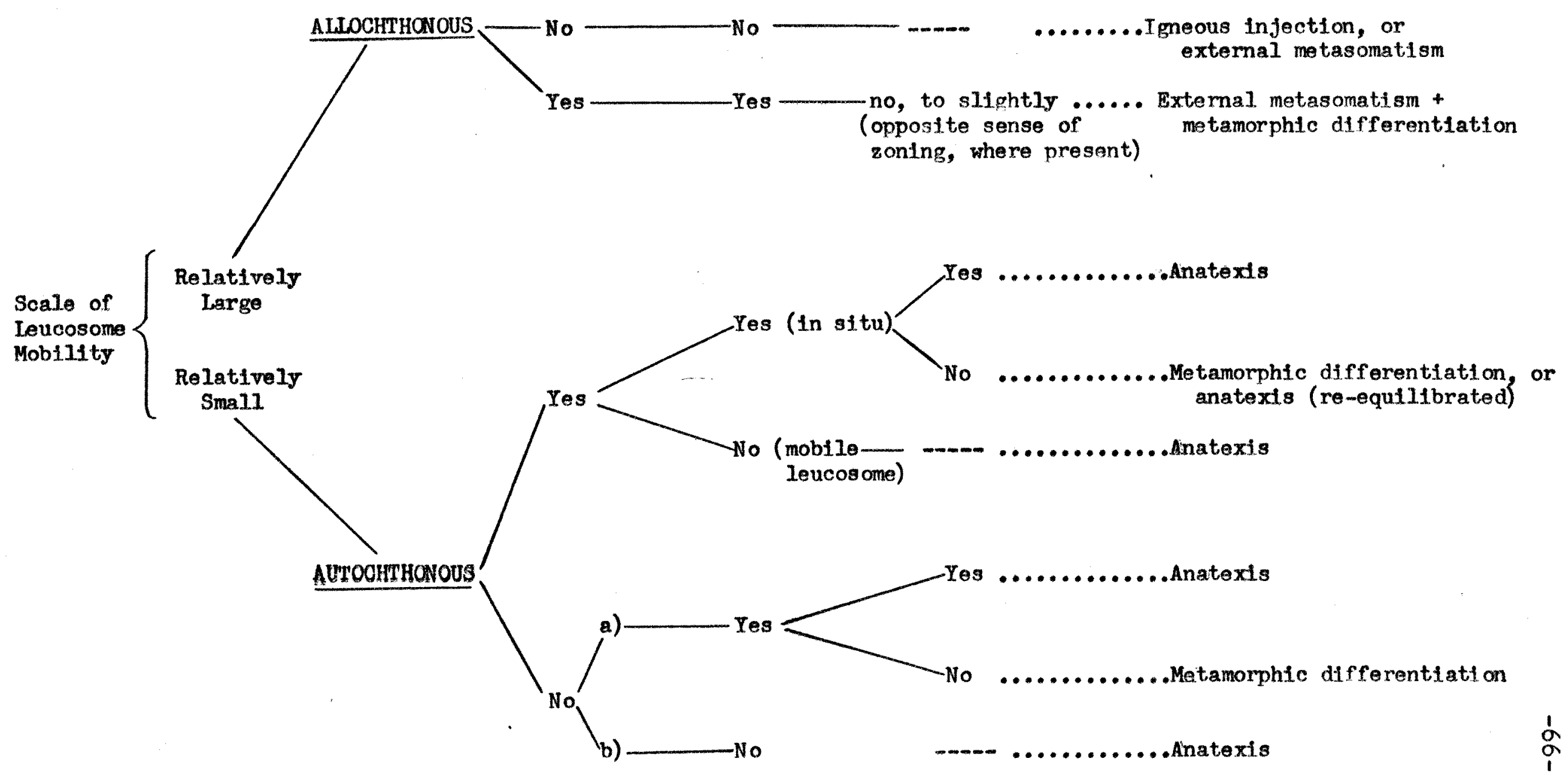

note: a) nev minerals (ex. K-feldspar)

formed during migmatization

TABLE 4 .

b) mobile leucosome ("Sederholm Effect") 
IV. MESOSCOPIC FEATURES AND PETROGKAPHY OF LEUCOCKATIC SEGREGATIONS IN THE STUDY AREA

A. AGE SUBDIVISIONS

A chronology of Eigmatization events has been established, based on cross-cutting leucocratic segregations. Coupled with structural controls of localization, different periods of migmatization may be placed within a structural frawework, as described in section II and outlined in Table 1. Although rather rare, exposures of all generations of cross-cutting leucosomes within rocks of corresponding chronology, exclucing dykes, have been documented. Careful definition of the mescscopic petrography ano mode of occurrence of each generation of leucosome, whose age relative to that of other leucosomes is indicated by discordant contacts, permits extrapolation frot this specific case to the general case, where no intrusive relationships are seen. Consequently, individual leucosomes may be related to a specific period of migmatization. Undoubtedly, some leucosomes will now and then be misidentified, however, the criteria by which different generations of leucosomes may be recognized and identified are both numerous and rigorous. In sampling and choosing meterial for thin section, only those leucosomes whose identification was certain were selected.

4 list of generalized criteria for distinguishing the products of different periods of Eigmatization is presented in Table 5 . Three types of criteria way be defined:

1) Petrographic: leucosome mineralogy and textures are directly related to paleosome composition. Primary fabrics are overprinted by tectonic granulation, particularly in older generations of leucosomes and in small scale segregations (eg. thin veins). 
2) Morphological: presence/absence of morphological subdivisions as defined by Mehnert (1968). This reflects the migmatization process, and is controlled in part by the structural control of leucosome accumulation (ie. mode of occurrence).

3) Mode of Occurrence: structural controls of leucosome localization. Leucosomes invariably accumulate in dilational zones (Fig. 23), that is, low pressure traps or "sinks". The size and shape of the segregation reflects the dimentions of the dilational zone as it developed through time. In situ leucocratic segregations almost invariably are controlled by the dominant schistosity in their source paleosome; discordant veins are rare, and provide the cross-cutting relationships necessary in establishing a relative chronology.

Very locally, intersecting products of migmatization episodes I, II (complex), and III may be observed within the same outcrop (Fig. 24). More commonly, however, two generations of leucosomes are seen to cross-cut. Plates $13 a, b$ show thin, granulated mobilizate I veins cross-cut by ptygmatically folded mobilizate I veins infiltrated and cross-cut by medium grained diffuse mobilizate IIa material, in paragneiss.

Folyphase migmatization II is subdivided into three principal phases: mobilizate Ila material accumulated in dilational openings of S2a schistosity in rocks of age groups I and II, while mobilizate IIb follows strain-slip cleavage surfaces (S2C) axial planar to F2c refolding of F2b-folds (which fold both the sa-schistosity and mobilizate IIa segregations; Fig. 3). As such, mobilisate IIb material consistentiy cross-cuts mobilizate IIa veins. However, recrystallization of mafic minerals in the paleosome of mobilizates commonly passively overprints both the paleosome and mobilizate I, IIa veins therein, adjacent to leuccoratic mobilizate IIb veins. Coarse grained pods of mobilizate IIc cross cut foliations $\mathrm{S} 2 \mathrm{a}, \mathrm{S} 2 \mathrm{c}$, and 
TAELE 5: Wesoscopio criteria for distinguishing different generations of mobilizates (not necessarily applicable to dyke rocks)

Mobilizate III

Petrography:

Coarse grained $(0.5$ to $15 \mathrm{~cm})$ granitio to trondhjemitic leucocratic pegwatites and granitoids. Composition unrelated to nost rock. Generally non-zraphic and unzoned. Deformed only by S3-shearing therefore usually are not Eranulated. Eiotite and hornblende are the mafic minerais; orthopyroxene is not seen, and tourmaline was found in only one location (ON-3). Not uncommonly contains significant magnetite.

Morphology:

Demonstrates do strict morphological features. Pegmatite masses are generally unzoned, and melanosomes are completely absent. Tend to recrystallize host rocks aliong narrow contact margins.

Mode of Occurrence:

Generelly irrespective of structural elements within host rocks (ie. usualiy cross-cuts S2a). However, at OS $-3,-4$ mobilizate III is preferentially localized along some s2c silp surfaces (Fig. 23,24 ). Forms centimetre to decametre scale dykes, pods, and irregular masses. Not uncommoniy have dislodged, recrystallized fragments of host hock. Pegmatites are of several generations, even dykes of similar compositions are seen to cross-cut.

\section{Mobilizate IIC}

Petrography:

Coarse greined (0.5 to $5 \mathrm{~cm}$ ) Eranitic pezmatoids identified only in grenite I peleosomes. Unlike mobilizate lia, mobilizate IIc leucosomes are generally unzoned (ie. quartz is not segregated in cores of veins). Postdates deformations IIb and IIc, therefore, like mobilizate III, these leucosomes generally are not granulated.

Morphology:

Well defined leucosome-melanosome relations. Melanosomes way be absent Where mobilizate IIc forms discordant pocs, however, concordant offshoots may have thick ( 5 or 6 mII) melenosomes grading diffusely into the granite I peleosome. Mobilizate II vein offshoots not uncommonly show pinch and swell, or are coarsely lobate.

Mode of Occurrence:

Iypical pccurrence is as lobate, metre-scale discordant pods with thick (5 to $20 \mathrm{cr}$ ) concoroant offshoots, paralleling S2a in the granite I paleosome. "Inclusions" (rafts) of granite I in mobilizate IIc masses snow no sign of rotation, neither are they recrystaliized by the leucosome.

\section{Mobilizate IID}

Petrography:

Mineralogy varies with host rock composition. Granitic

(microcline-quartz-plagioclase) leucosomes are found in granitic gneisses;

trondhjemitic (plagioclase-quartz; plagioclase composition not implied)

leucosomes are found in concoroant amphibolite. Not uncommonly, mobilizete IIb contains streaky mafic ciots, chiefly consisting of recystallizeo poikilitic (ouartz inclusions) hornblende porphyroblasts, oriented paraliel to the vein. Sze is represented in mobilizate IIb by tectonically aligned ovartz plates. 
(Table 5, cont'd)

Morphology:

Lacks a marginal melanosome, indicating mobility on a metre-scale (at the most). Mineralogy always consists of the same minerals as found within host rock (paleosome). These leucosomes may range in thickness from well defined $1 \mathrm{~cm}$ thick veins, to more diffuse leucocratic bands, rich in mafic clots. Mafic clots may occur within the band itself, or may diffusely overprint adjacent paleosome/ mobilizate IIa material over a distance of tens of centimetres. Restricted to S2c strain slip shear surfaces, mobilizate IIb veins usually are closely $(<50 \mathrm{~cm})$ spaced.

Mode of Occurrence:

Mobilizate IIb veins are restricted to S2c strain slip cleavage surfaces, axial planar to F2c folds, locally seen to refold F2b folds, as outlined by mobilizate IIa veins. Locally, mobilizate IIb material offshoots from the $52 c$ surface, forming veins of identical petrography, here concordant to $S 2 a$ in the paleosome. Wider bands of mobilizate IIb commonly isolate in situ "inclusions" of paleosome (+ mobilizate IIa) whose shape is controlled by arcuate (F2b-folded) S2a surfaces, truncated on two sides by S2c. The mobilizate is best represented in granite I paleosomes.

\section{Mobilizate IIa}

\section{Petrography:}

Mineralogy of mobilizate IIa varies with host rock composition. Granitic leucosomes are found in granitic gneisses; trondhjemitic leucosomes are restricted to concordant amphibolite. Leucosomes occasionally contain well formed mafic minerals, or ragged clots of mafic minerals, whose mineralogy always matches that of the melanosome, which is most often present, bordering mobilizate IIa segregations. In paragneisses, leucosomes may contain microcline, quartz, (plagioclase) as well as garnet, cordierite and retrograde biotite and sillimanite (both intergrown with quartz). Melanosomes consist of biotite and sillimanite.

Morphology:

Generaily consists of well defined leucosomes-melanosomes. Mineralogy of these always matches that of the paleosome, indicating an in situ origin, with minimal mobilizate migration. Mélanosomes may be thin ( 1 $\mathrm{mm}$ ) and well defined, or thicker (to $5 \mathrm{~mm}$ ) diffusely grading into the paleosome. Melanosomes may impinge upon one another where leucosomes are closely spaced "double restite"). In granite I, mobilizate IIa veins typically have quartz rich central cores.

Mode of occurrence:

Controlled by flexural opening of S2a-schistosity in the paleosome, and by dilation zones related to F2a folding (fold hinges, interboudin infilings, infilings of brecciated dykes, etc.). Móbilizate IIa material frequentiy is migratory, accumulating in breccia interstices and intersecting dyke amphibolites. In these cases, no melanosome is present, and the leucosome typically recrystallizes the host in which it has accumulated, provided that the host has a markedly different composition compared to the paleosome source of the leucosome (ie amphibolite dykes in granitic gneiss). Mobilizate IIa veins not uncommonly intersect, indicating that mobilizate IIa generation and crystallization occurred over a period of time, so not all leucosomes were concomitantly fluid. Mobilizate IIa veins are folded by fab, refolded by F2c, and cross-cut by mobilizate IIb veins.

\section{Mobilizate I}

Petrography:

Leucosome mineralogy varies with host rock composition. As such, mobilizate I veins are of a similar composition as mobilizate IIa veins 
(Table 5, cont'd)

Within the same paleosome, however, the latter are always cqarser grained, These veins usualiy are pale grey in all rock types.

Morphology:

Leucosomes are thin $(2$ to $5 \mathrm{~mm}$ ), and show only scant relicts of melanosomes (usually biotite, hornblende, pyroxene (rare). In pelitio paragneiss, melanosomes typically contain prograde biotite and sillimanite. Grain size of mobilizate I matches that of the paleosome, both components having suffered granulation due to deformation I and subsequent folding episodes, while mobilizate IIa is coarser grained, by .p to a factor of 20 over and above the paleosome.

Mode of Occurrence:

As flattened isoclinal folds (F2a). Vein surface represents $\mathbf{S 1}$; the axial plane of F2a parallels S2a. These veins are cross-cut by mobilizate IIa, and younger, leucosomes. 
mobilizates IIa and IIb (Fig. 28). Different aspects of these relationships are presented in Section IVB(2,3) (Plate 32a-d, and Figures 8 and 27. )

However, this subdivision of migmatization into two phases is an oversimplification. The continuity of layering in zones containing in excess of 40 or 50 volume mobilizate II material, and the local intersection of this material (Fig. 17, inset) indicate that not ail of the mobilizate IIa material within a given exposure was fluid at the same time. Indeed, were all of this pegmatoid simultaneously fluid, one might expect it to have coalesced and migrated out of the system, as indicated by Ramberg (1956), instead of consistently being bordered by melanosome seams, indicating migration of a small (m-scale at most) scale. Furthermore, agmatitic structures are rarely seen in the study area. Aside from the morphologies of mobilizate II material described above, on a practical basis only three (mobilizates IIa,b,c) categories of migmatization II leucosomes may consistently be distinguished.

Although mobilizate III pegmatites typically form metre-scale masses, here and there thin pegmatite dykes, granitic to trondhjemitic in composition, and not uncommonly rich in magnetite, cross-cut migmatization I and II segregations. Thin veins or dykes of mobilizate III may resemble coarse grained mobilizate IIc leucosomes, however, the former are never rimmed by melanosome seams, and are rarely granulated, except where containing an internal S3-schistosity (Figs. 9, 26), and are unfolded (Table 5). Figure 26 shows a granitic nobilizate III dyke cross-cutting concordant, coarse grained mobilizate IIa segregations in granite IIb, while Plate 14 shows a greenish-coloured trondhjemitic, magnetite rich mobilizate III vein cross-cutting pink granitic mobilizate I material filling interstices between a boudinaged amphibolite II dyke, in granite $I$. 


\section{FIGURE 24.}

Nobilizate cross-cutting relationships, in pranite I. Inset shows F1 folded fine crained grey mobilizate I veins cut by a medium grained ptygmaticaliy folded mobilizate IIa vein (reproduced in Plate 13a). This material is itself cut by a slightly granulated coarse grained potash feldspar-quartz rich mobilizate III dyke, whose attitude is apparently controlled by S2c strain slip cleavage surfaces seen elsewhere in the outcrop. These are, however, F2b folds; no mobilizate IIb is seen in the outcrop area represented by the figure.

\section{FIGURE 25.}

a) Sketch from photograph of hand sample of paragneiss from St. Fulgence. Hand sample provided by F. Lacoste.

b) Explanation: F1 folded fine grained, pale grey mobilizate I veins have S2a (somewhat contorted) as axial plane. The mobilizate I material is cross-cut and infiltrated by medium grained pink (microcline rich) mobilizate II.

\section{FIGURE 26.}

Thin dyke of peamatitic mobilizate III cutting large concordant pods of mobilizate II in granite IIb. The mobilizate II is medium grained, and contains $1 \mathrm{~cm}$ uralitized pyroxene metacrysts (c.f. Plates 28b, 29). The mobilizate II dyke can be followed alone strike for some $10 \mathrm{~m}$, and contains an internal $\mathrm{S} 3$ shear fabric, translation has bent the strong $S 2 a$ schistosity in the granite IIb host, indicating the sense of movement. The mobilizate II contains guite fresh black hornblende crystals, along with considerable potash feldspar and quartz. 


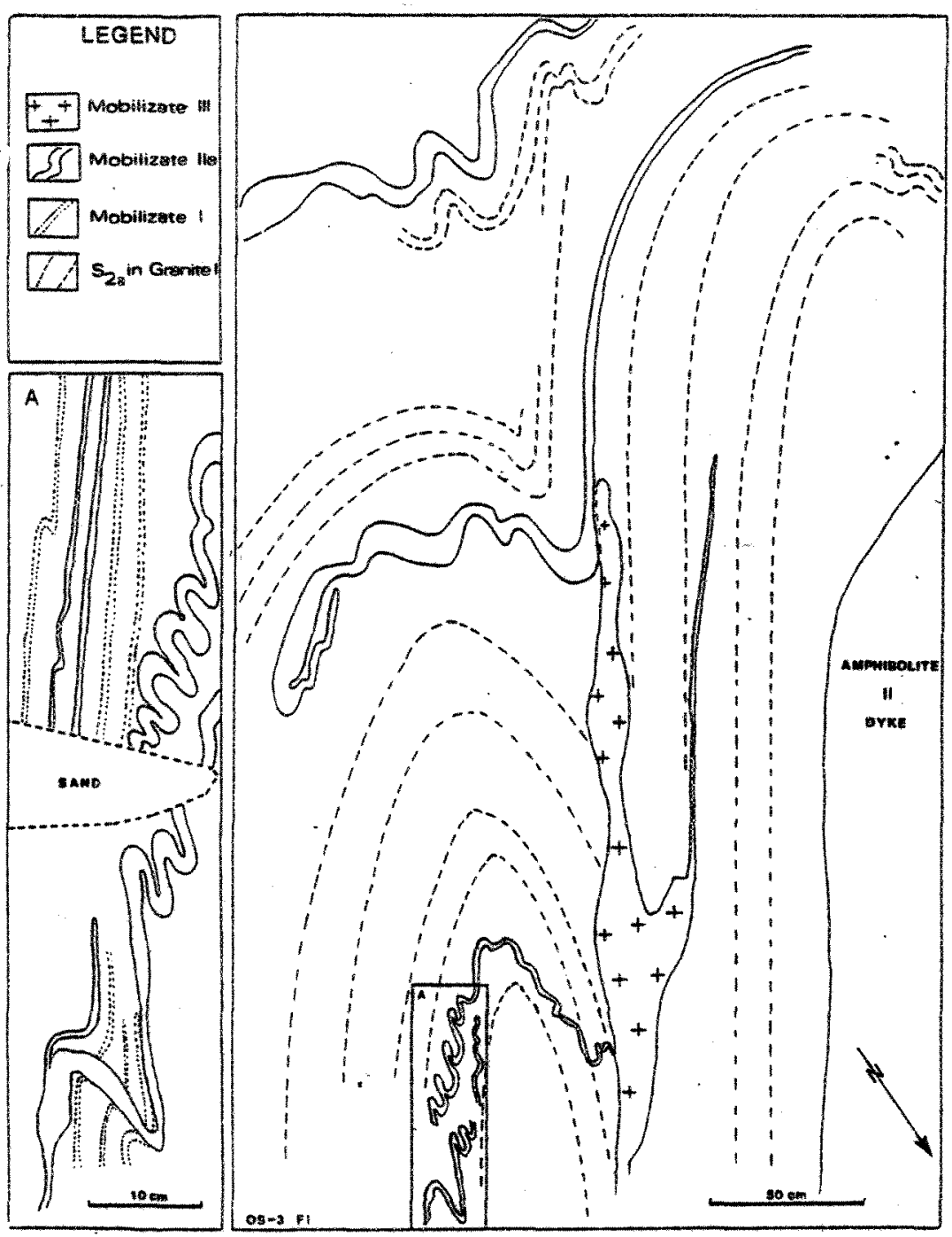

FIGURE 24 .
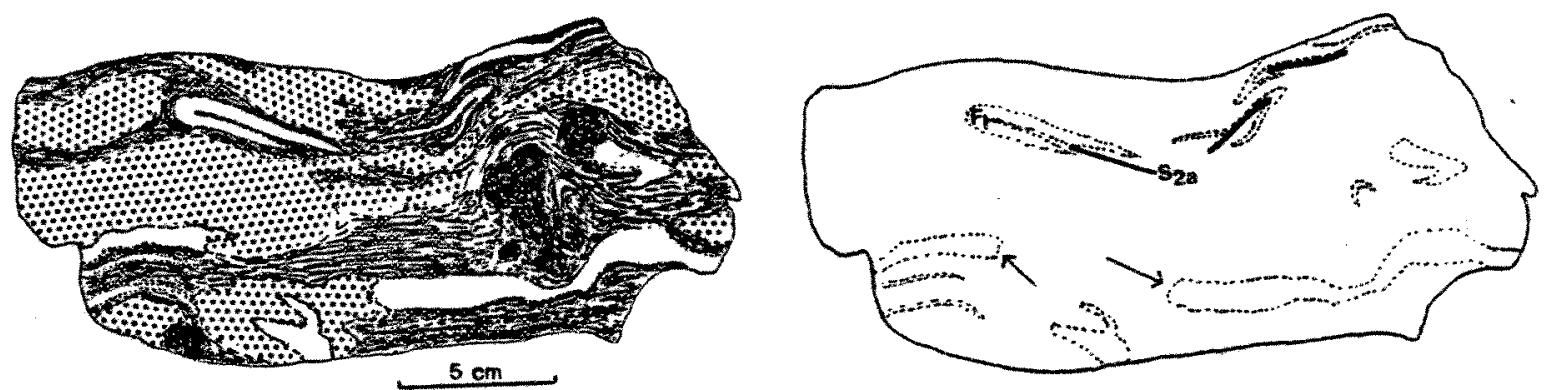

GARNETS

BIOTITE SELVAGES

MOBILISATE $\mathrm{Ha}_{\mathrm{B}}$

TIGHTLY FOLDED MOBILISATE । 


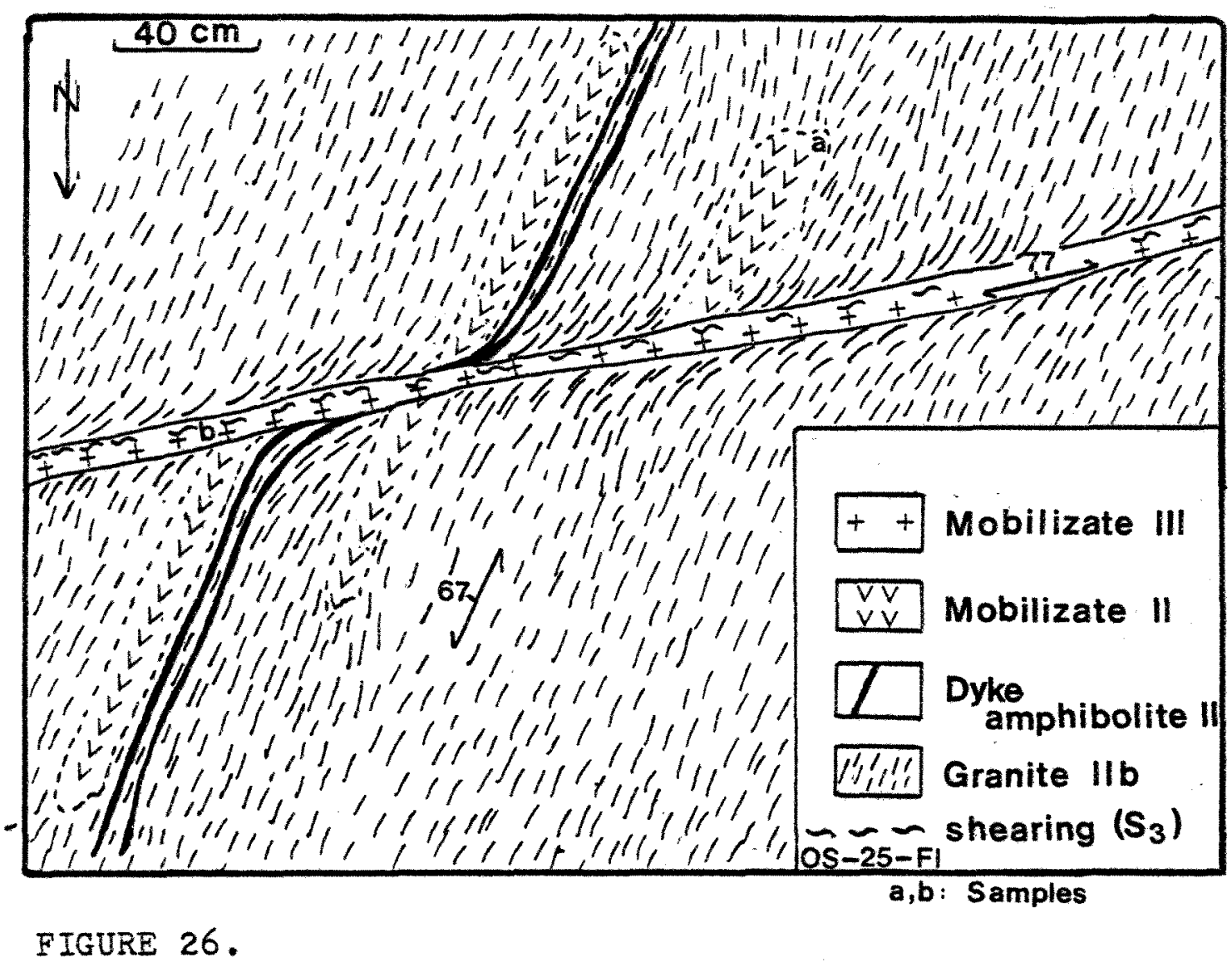


Figure 27 Sumary of occurrences of different generations of

(Scale of sketches is variable: width of mobilizate II segregations ray be used as an indicator of scale, insofar as these mobilizates typically range from 1 to $10 \mathrm{~cm}$, up to about $1 \mathrm{~m}$ in the case of example B)

A-1: mobilizate II material filling dilation zones between dyke amphibolite II boudins. The dyke is shown as being concordant to the S2a schistosity in the host gneiss, indicating that both dyke pinch and swelling, and mobilizate II generation, are related to deformation IIa. This observation represents the only evidence that mobilizate II generation commenced during F2a; most mobilizate Ila material segregates in dilational flexures of $\mathrm{S} 2 \mathrm{a}$, developed during F2b folding.

A-2: pinch and swell in a mobilizate IIa vein.

A-3: mobilizate IIa vein cross-cutting $S 2 a$ and isoclinally folded mobilizate I veins

A-4: mobilizate II material filling interstices between dyke amphibolite breccia fragments, presumably formed during deformation IIa (c.f. Fig. 17) Source of the mobilizate is the gneissic host to the dyke. As such, the mobilizate is usually granitic, and recrystallizes margins of amphibolite fragments, as do vein-like mobilizate penetrations following the dyke's S2a schistosity, as indicated in example $\mathrm{A}-1$.

A-5: Hobilizate IIa filling dilational leaves: flexural openings of S2a developec during deformation IIb.

A-6: pods of mobilizate II material, following $\mathrm{s} 2 \mathrm{a}$ in the paleosome.

A-7: mobilizate IIb following $\$ 20$ strain slip cleavage surfaces, cutting mobilizate IIa veins outlining $S 2 a$ in the paleosome.

B: mobilizate IIc in dilational zones of S2b folding, Note that layerine ( $S 2 a$ ) and folds (F2b) of the gneiss are continuous between the rafts, indicating that these have not been displaced.

C-1: mobilizate II material accumulating in $F 2 b$ flexural zones, typical of granites I and II.

C-2: thin dyke of mobilizate III cutting an s2a-concordant mobilizate IIa segregation, demonstrating age relationships.

D: although mobilizate III usually cross-cuts gneiss foliations (ex. C-2, above), this material locally is controlled by S2c surfaces, thereby paralleling mobilizate IIb segregations, as at $0 S-3,-4(F i g, 2)$. In this case, the pegmatite veins are emplaced 1 to 2 II apart.

E: mobilizate II accumulating in dilation zones associated with displaced fold hinges. The gneiss is lineated in the hinges.

F-1: melanosome forming border of mobilizate IIa vein, where direction of mobilization was perpendicular to the length of the vein.

F-2: melanosome streaks forming between/within mobilizate IIa veins in which direction of mobilization was parallel to the length of the vein.

G: "spider morphology", typical of mobilizate II material in banded concordant amphibolite. The mobilizate II cuts mobilizate 
Figure 27 (contid)

I veins, which show Fl-isoclinal folding. The mobilizate II spider morphology is characteristic of the concordant amphibolite, since this type of paleosome, due to cm-scale interbanding, is strongly pinch and swelled (E2a). Both mobilizate I and II material is trondhjemitio (plagioclase composition not implied; ampribolite plagioclase is labradorite). 


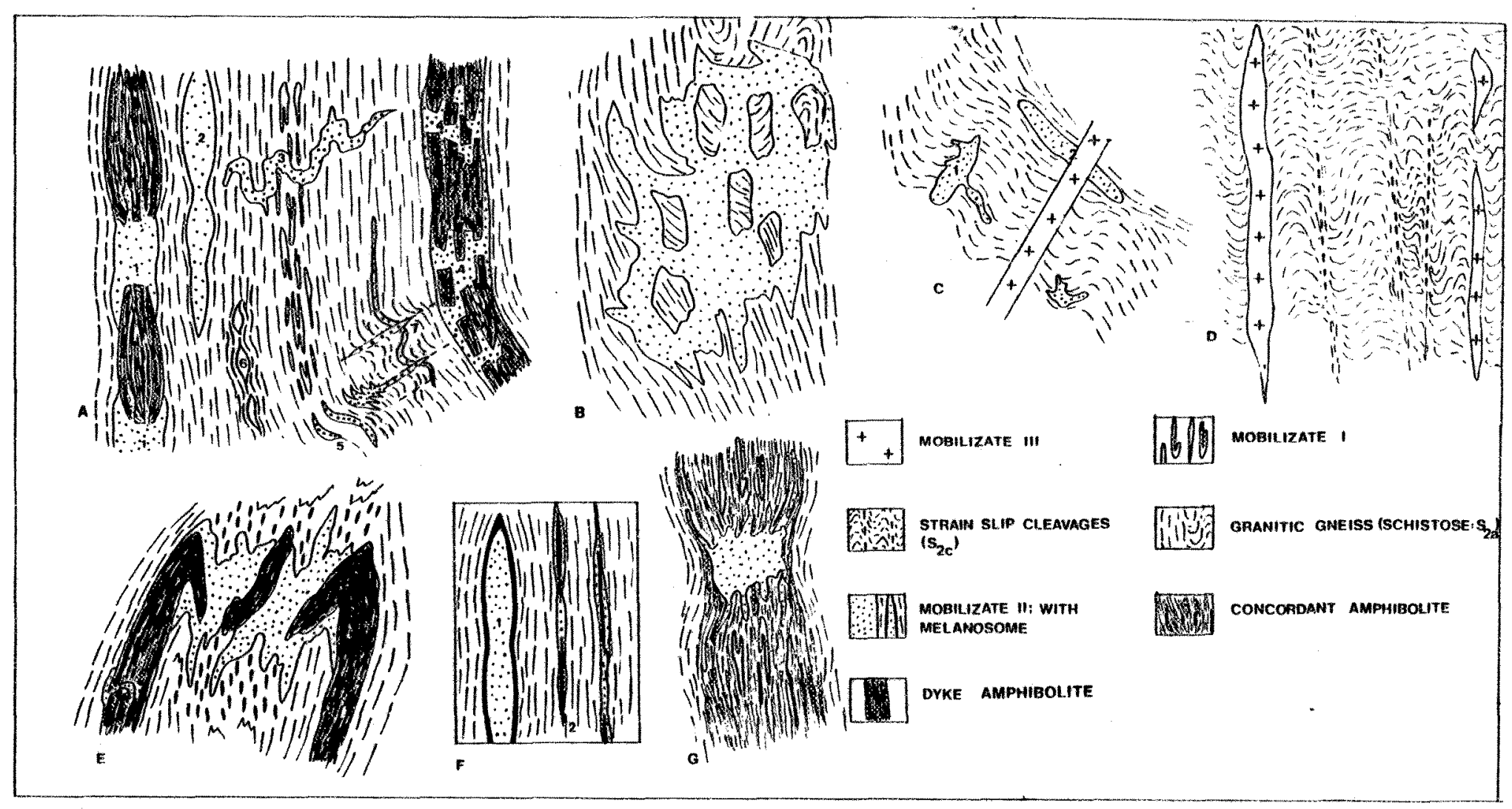

FIGURE 27. 
PLATE 13. Cross-cutting mobilizate relations in granite I.

a) F2b folded medium grained mobilizate IIa vein cuts granulated, F) folded mobilizate I veins. C.f. Fig. 24, inset. Location: $0 S-3$. Scale in cms.

b) Hand sample 0N-2-6. Ptygnatically folded, medium grained, rose coloured mobilizate Ila vein cuts thin, fine grained, light grey coloured planar mobilizate I veins (upper right).

PLATE 14.

a) Mobilizate II cutting mobilizate II in granite I. For explanation, see

b) Trondhjemitic mobilizate III dyke cross-cutting mobilizate II infiltrating interboudin dilation zone. Source of the mobilizate II is the granite I host to the boudinaged dyke amphibolite IIb. Note the recrystallizing effect of the migrant mobilizate: amphibole clots abound. The thickness of the mobilizate III dyke at left of figure is exaggerated due to outcrop surface relief. 


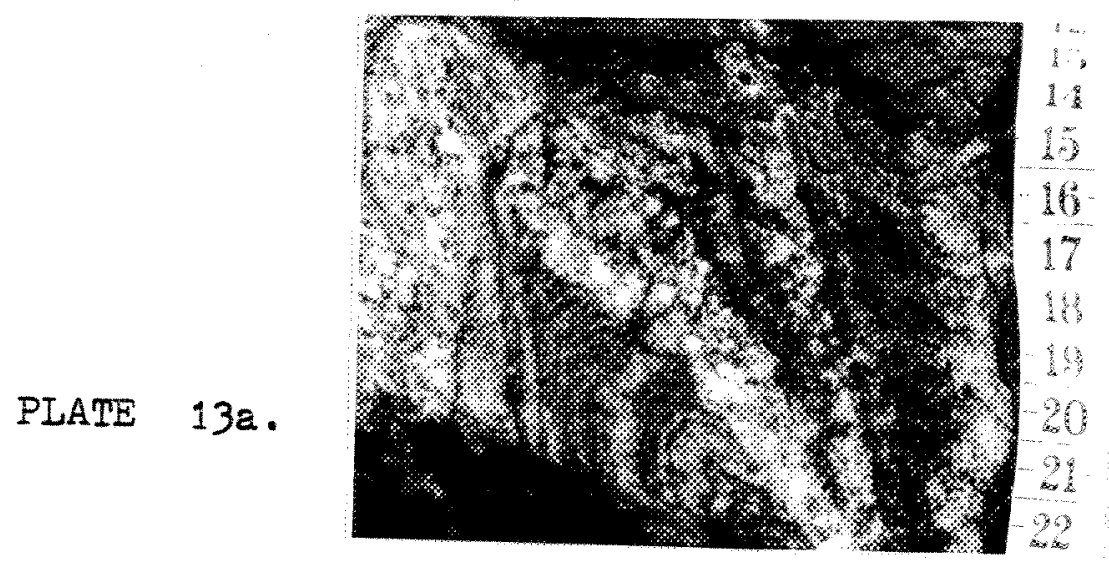

PLATE $13 b$.

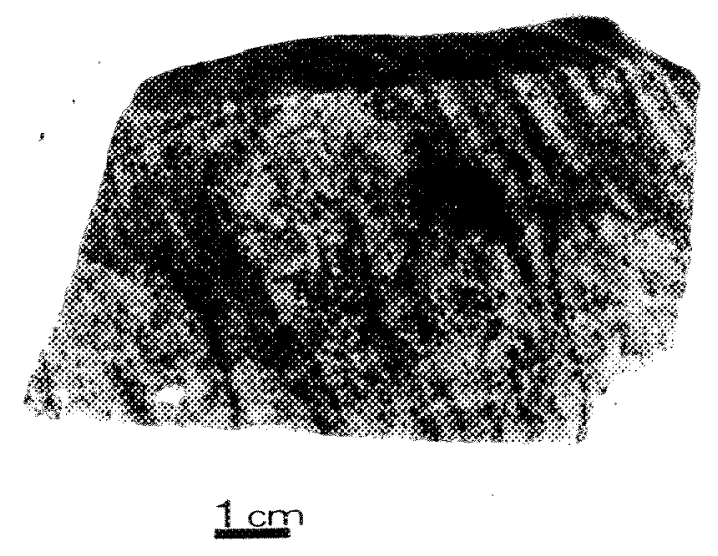




\section{$-76-$}

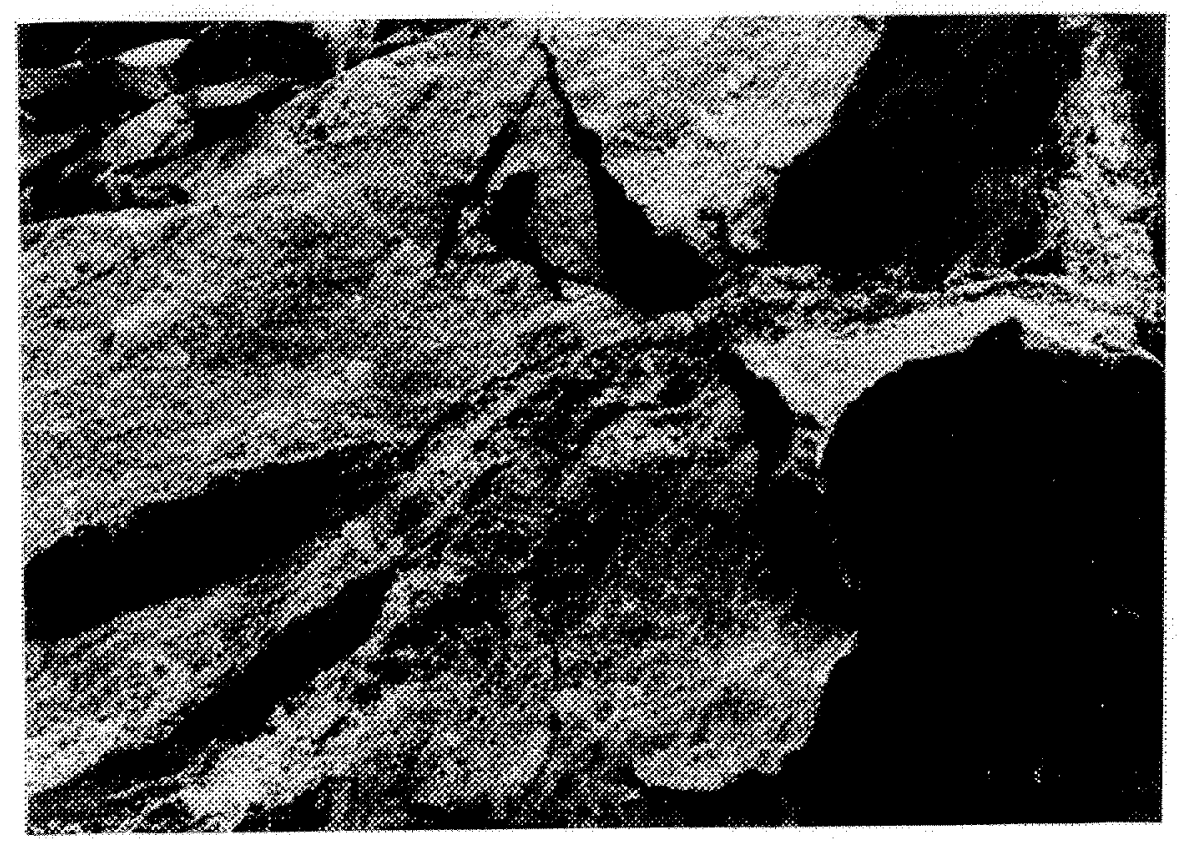

a) PLATE 14.

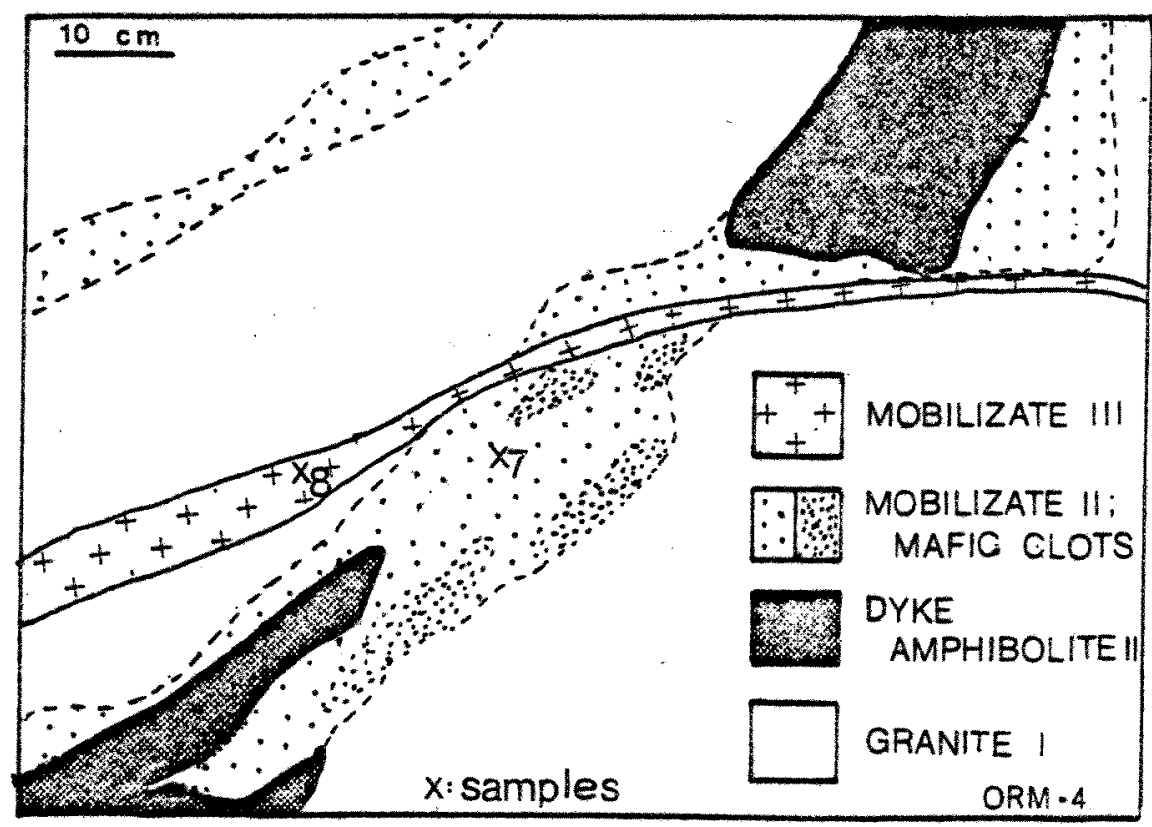

b) Explanation. 


\section{E. PETROGRAPHY OF THE MOBILIZATES}

Mesoscopic features of all generations of mobilizates have been described in general terms; cross-cutting relationships have been described in section IVA, and criteria for distinguishing the different generations of mobilizates are summarized in Table 5 . Petrographic features of each generation of mobilizate will now be described for each type of paleosome.

\section{1-Mobilizate I}

Mobilizate I occurs uniquely as thin $(<1 \mathrm{~cm})$ veins, tightly folded by deformation $I$, in all rocks of age group $I$. As a result of this, and subsequent, deformation, the grain size of these veins closely matches that of the adjacent paleosome. Only vestiges of melanosome seams are seen bordering mobilizate I veins; these selvages rarely attain $1 \mathrm{mw}$ in thickness. As a result, comparison of plagioclase compositions in the leucosome and melanosome is not possible, insofar as plagioclases lying within the sparse melanosome cannot be clearly distinguished from those in the adjacent paleosome. Nevertheless, it is seen that there may be a marked increase in the proportion of mafic minerals in the relict melanosome, compared to the paleosome; mafic mineralogy is identical in both cases. As a result of granulation or recrystallization, melanosome material is marginally finer grained than either the leucosome or paleosome.

The composition of mobilizate I veins varies with the paleosome. Mobilizates in granite I are granodioritic (Table 6-1); those in concordant amphibolite are trondhjemitic (Table 6-3). Mobilizate I veins in paragneiss contain significant quantities of microcline, in the virtual absence of plagioclase (Table 6-2). Furthermore, mobilizate $I$ veins in paragneiss contain neither garnet nor cordierite, although mobilizate II leucosomes within the same hand 
sample commonly contain one or both of these minerals. Homogeneous paleosomes do not occur within the paragneiss sequence: the compositional heterogeneity of the unit results from the polyphase mobilization of what was initially a thinly bedded heterogeneous sedimentary sequence. As such, the paragneiss is a banded gneiss, often containing in excess of 60 volume $\%$ leucosomes (mobilizates I and II). Possible paleosome material may nevertheless be locally recognized as homogeneous, discontinuous layers separating leucosomes, in which mafic minerals are more or less evenly distributed. These same mafic minerals, in particular biotite and sillimanite, segregate, forming melanosomes bordering the in situ leucosomes. The paleosome material rarely contains significant proportions of plagioclase; like the leucosomes, the paleosome contains microcline and quartz as important leucocratic minerals.

i. Mobilizate I in Granite I.

Characteristics of mobilizate I-granite I mineralogy are outlined in Table 6-1. This same material is portrayed in hand sample ON-2-6 (Plate 13b), and in thin section as Plate 15a. This material is texturally identical to the host granite I paleosome, and may be described as granoblastic polygonal. The vein material is quartz rich, with quartz occurring as lobate to elongated grains up to 4.8 $\mathrm{mm}$ long (exceptional). Potash feldspar occurs as xenomorphic grains $(0.2$ to $1 \mathrm{~mm})$ irregularly distributed along the vein, as grid-twinned microcline, less commonly with patchy exsolved plagioclase. As a result of the uneven distribution of $K-f \in I d s p a r$, parts of the vein consist of quartz-plagioclase. Plagioclase, locally perthitic, occurs as equigranular, xenomorphic to subidiomorphic grains, forming mosaics with quartz and with quartz-K-feldspar. Sample ON-2-6 is unusual insofar as the granite I contains clinopyroxene and biotite instead of hornblende-biotite as mafic minerals. Along with opaques and sphene, clinopyroxene and biotite segregate along parts of the vein, representing an enrichment factor over and above the paleosome of 0 to -2 (Table 6-1). Marics occur in sparse quantities in the leucosome. 
ii. Mobilizate I in Paragneiss.

Characteristics of mobilizate I-paragneiss mineralogy are outlined in Table 6-2. The typical field aspect of this material is shown in Plate 16a; the photomicrographs in Plates 15b,c show material similar to this, sampled from the same outcrop. Paragneiss thin sections with mobilizate I veins also contain mobilizate II leucosomes (Plate 16a; photomicrograph Plate 15bii), seen to cross- cut the first. Although mobilizate I veins are rather rare in granite $I$, they are well represented in paragneiss. Leucosome veins generated by migmatization I and II tend to be closely spaced in the paragneiss, consequently melanosomes of adjacent veins commonly juxtapose, enhancing the leucocratic-melanocratic layered aspect of the rock. At the same time, veritable paleosome material is poorly represented: migmatization-related heterogeneities abound between well developed leucocratic veins, rendering a comparison of leucosome - paleosome relations difficult. However, leucosomes always match the mineralogy of the adjacent gneiss, in particular, paragneiss motilizate I veins, like the host gneiss, are microcline-quartz assemblages, in which plagioclase is a minor $(\langle 10 \%)$ component. Unlike mobilizate $I$ in granite I, mineral species are often inequigranular (Plate 15b). All leucocratic phases, including plagioclase, are xenomorphic, ouartz not uncommonly being polygonal. Therefore, the texture of these veins may be described as xenomorphic-heteroblastic (Flate 15b) to polygonal granoblastic. Typical grain size ranges for vein minerals.match those in the adjacent gneiss. Leucosomes generated during migmatization II are always considerably coarser grained than both mobilizate I and the gneiss.

Mobilizate I veins in paragneiss are quartz-microcline rich. Quartz forms polygonal to serrated (Plate 15c) mosaics with microcline. Individual quartz grains are polygonal to lobate-serrated in shape, and are not oriented. Individual veins may contain in excess of 50 volume q quartz; xenomorphic, grid-twinned microcline 
makes up the bulk of the remainder of the leucosome, exclucing small amounts of plagioclase and included mafic minerals, chiefly randomiy oriented biotite, and thin curtains of sillimanite. Excluding these, the quartz-K-feldspar ratio may vary between $7: 3$ and $4: 6$ in different veins. Neither garnet nor cordierite has been observed in paragneiss mobilizate I veins.

iii. Mobilizate I in Concordant Amphibolite.

Characteristics of mobilizate I-concordant amphibolite mineralogy are outlined in Table 6-3. The typical field aspect of this material is shown in Flate 16b; the photomicrograph in Plate 150 shows vein material similar to this, sampled in the same outcrop. Migmatization I and II leucosomes in concordant amphibolite consistently are trondhjemitic (note: plagioclase is labradorite) in composition. Melanosomes are not seen, neither are paleosome interfaces juxtaposing the leucosomes recrystallized. Mobilizate I here may be described as polygonal granoblastic. Quartz forms polygonal to lobate, equigranular grains, forming mosaics with xenomorphic to hypidiomorphic plagioclase. Grain size is similar in both the leucosome and paleosome. Plagioclase-quartz ratios are fairly consistent, ranging from about $65: 35$ to $50: 50$.

Typical textures of granulite-grade gneisses are outlined in Table 7a. Table $7 b$ compares paleosome textures with those textures seen in the different generations of mobilizates. Modal analysis data for paleosomes and mobilizates are listed in Appendix. 1; modal compositions of the leucocratic fractions of mobilizates are presented graphically as Figure 37 , in the Discussion (section $V$ ). 
PLATE 15. Photomicrographs of mobilizate I in various paleosomes.

a. (i) Mobilizate I in clinopyroxene-bearing aranite $I$. With the exception of the large quartz patch at the top of the photograph, the mobilizate is roughly equigranular, having a granulometry similar to the paleosome. The paleosome has a higher microcline:plarioclase ratio than the mobilizate, unlike a ptymatically folded mobilizate IIa vein in the same sample (c.f. Plate 13b). Thin section ON-2-6. X-nicols. Bar: $2 \mathrm{~mm}$.

a. (ii) As above, but in plane polarized light. Note the weak enrichment of mafic minerals (clinopyroxene, opaques, sphene, biotite) in the relict melanosome. Typical paleosome mafic content is seen at left in photograph: at most the melanosome has a two- to threefold mafic enrichment over this.

b.(i) Mobilizate I in paranneiss. The leucosome is rich in guartz (o) and microcline: only a few grains of plagioclase (p) are seen. At left, a sililimanite (s) rich melanosome borders the mobilizate. The melanosome also contains cuartz plates paralleling the vein. Inin section $0 \mathrm{~N}-2-4 b$. $X-n i c o l s . ~ E a r: 1 \mathrm{~mm}$.

b.(ii) Same vein as illustrated above, being intersected by coarser grained mobilizate IIa, having a higher microcline:quartz ratio (c.f. Fig. 36 ). Bar: $1 \mathrm{~mm}$.

c. Mobilizate I in paragneiss. The leucosone is compositionally and granulometrically similar to b(i), however, this vein has lobate and serrated microcline-quartz mosaics, rather than polyconal mosaic contacts. Thin section Or-2-4a.'X-nicols. Bar: $1 \mathrm{~mm}$.

d. Mobilizate I in concordant amphibolite. The levcosome is trondhiemitic, with lobate quartz, and twinned, hypidiomorphic plagiociase. At centre of photograph is a thin fine grained biotite-cuartz-plarioclase band separating two mobilizate I veins, possibly representing the melanosome. Thin section os-1-5. $X-r i c o l s . ~ B a r: ~ i m$. 


\section{$1, \%$}

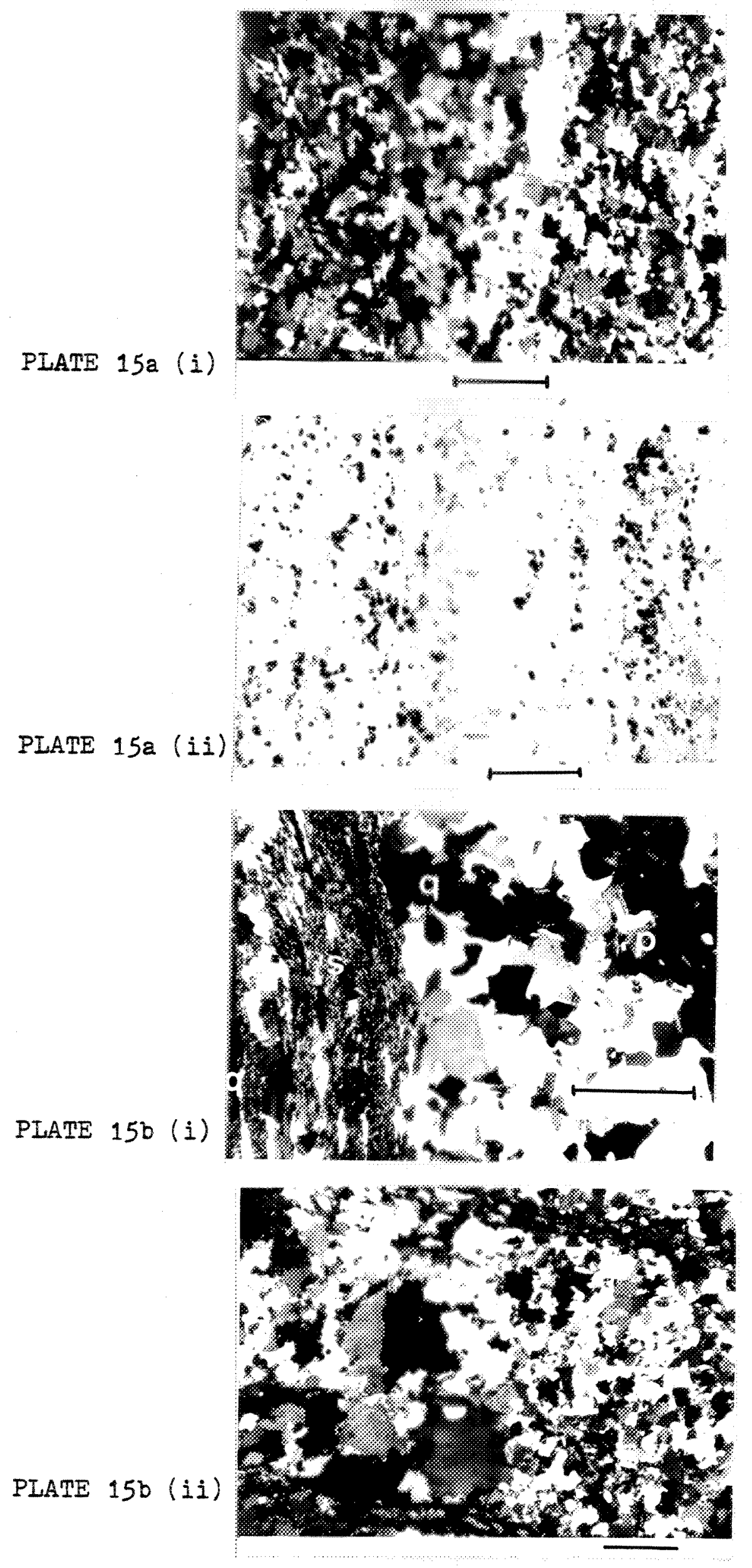



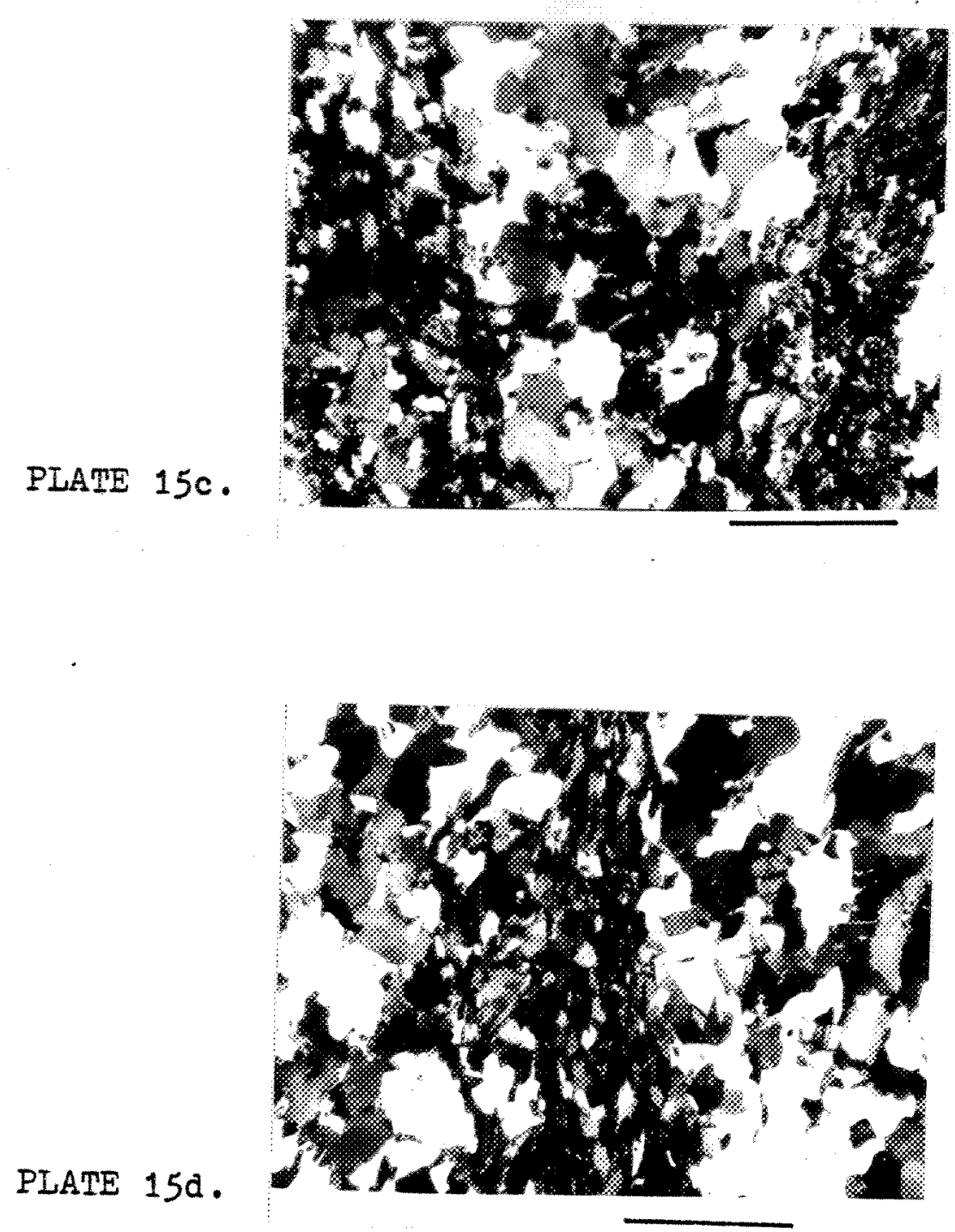
PLATE 16.

a. F1 flattened folds shown by thin, granulated mobilizate I veins in paragneiss. Note ill-defined, medium grainec patch of mobilizate II intersectinf mobilizate I veins. Below the scale (base of photo) is a $2 \mathrm{~cm}$ thick, well defined mobilizate IIa vein witn $1 \mathrm{~mm}$ thick biotite melanosomes. Note the host gneiss (paleosome) is heterogeneous, consisting of thinly banded Eneiss, in this case, the thin leucosomes/melanosomes are products of miematization I. Location: ON-2.

b. Relatively thick ( $1 \mathrm{cr}$ ), folded and coalescine ribbons of mobilizate I (below hamer) in concordant amphiboiite. Above hammer handle is medium grained mobilizate IIa, easily distinguished from the fine grained mobilizate I' Both mobilizates are, however, compositionally similar, consisting of plagioclase (labradorite)-quartz. Location: OS-1. 
PIATE $16 a$.

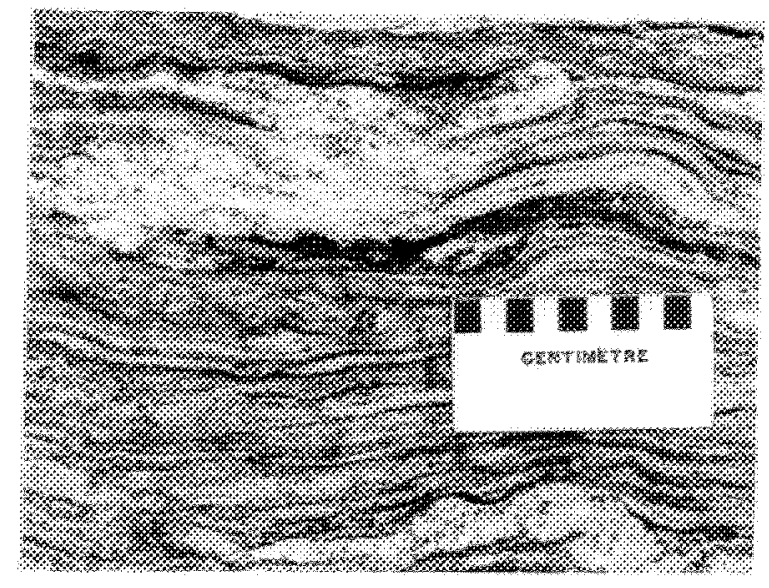

PIATE 16b.

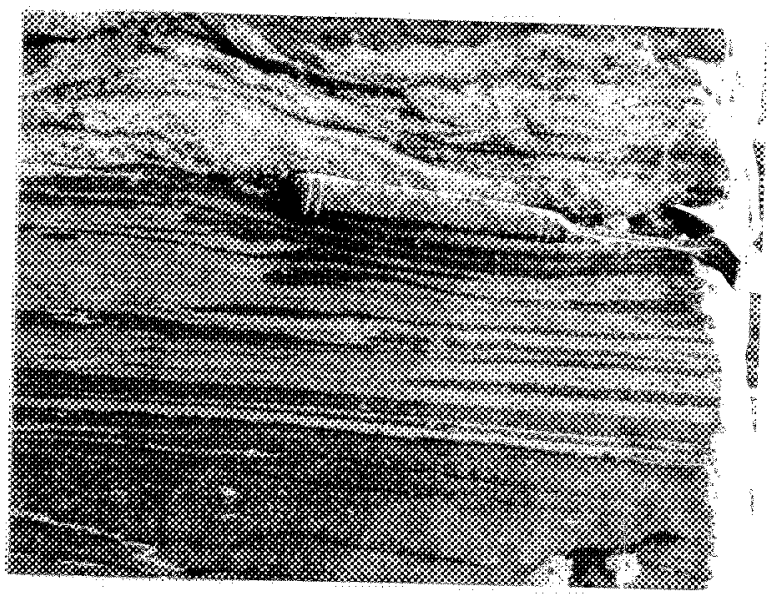


TABLE 6-1: Mineralogical characteristics of mobilizate I-paleosome. GRANITE I: (thin section ON-2-6)

Note: The fabric of granite $I$ and contained mobilizate $I$ is dominated by tectonic recrystalization effects. Consequently, mobilizate I vein textures are the products of deformation; these equigranular textures are not primary (see Tables 7a, 7b)

Thickness (mm): Typical grain size: * mafics:

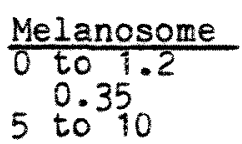

\section{K-Feldispar} Typical grain size: Grid twin: Antiperthite:

Mode of occurrence:

Plagioclase Typical grain size: Zoning:

Alteration:

Myrmekite:

Mode of occurrence:

Quartz: Tyoleal grain size: orientation:

Extinction:

Mode of

occurrence:

Mafic Minerals

Clinopyroxene ; grain size: Mode of occurrence:

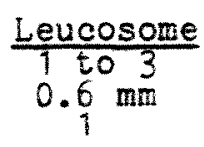

\section{$0.5 \mathrm{~mm}$} common present

equigranular xenomorphic grains

$0.5 \mathrm{~mm}$
none
slight
common

$0.5 \mathrm{~mm}$

slight

equigranular $0.9(\max .4 .8)$

larger grains may parallel vein lobate to

$$
\begin{aligned}
& 0.3 \\
& \text { present } \\
& \text { present } \\
& \text { (patch, flame) } \\
& \text { granular } \\
& \text { mosaics with } \\
& \text { qz-plag. }
\end{aligned}
$$

0.4 none slight to moderate common
Paleosome<smiles>[2H][B]</smiles>

0.4 common present

$$
\begin{aligned}
& \text { equigranular } \\
& \text { mosaics with } \\
& \text { qz-plag. }
\end{aligned}
$$

0.5 none slight common
0.4

small az plates parallel vein
0.5

none seen

larger grains in all components show undulose extinction equigranular-lobate polygons

trace; $0.3 \mathrm{~mm} 1 ; 0.3$ iomorphic crystals, locally partly mantled by (retrograde) green hornblende, subsequentiy altered. Hornblende is a common mafic accessory in granite $I$, hence the virtual absence of this in the sample suggests that the breakdown of amphibole gave rise to the pyroxene.

Biotite

Móde of occurrence: trace 0.2 to $0.5 \mathrm{~mm}$ flakes paralleling $\mathrm{s} 2 \mathrm{a}$

Also occurring in the different components are trace amounts of fine grained $(0.2$ epidote, opaques, sphene, apatite. 
TABLE 6-2: Mineralogical characteristics of mobilizate I-paleosome.

PELITIC PARAGNEISS: (thin sections ON-2-4a,b)

Note: no homogeneous paleosome exists in pelitic paragneiss. However, leucosomes are bordered by mafic-enriched selvages (melanosomes), easily distinguished from the adjacent paleosome gneiss.

Thickness $(\mathrm{mm})$ :

Typical grain size:

thafics:

K-Feldspar

Iypical grain size:

Grid twin:

(Anti)perthite:

Mode of

occurrence:

Marginal symplectic

intergrowths:

Ouartz

Typical grain size:

orientation:

$\frac{\text { Leucosome }}{1.5012}$

Melanosome

0.5 to 1.5

350

$0.4 \mathrm{~mm}$

common

not seen

K-spar not seen

not seen

xenomorphic,

heteroblastic grains

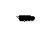

common (microgranophyric)

Paleosome

$15 \stackrel{0}{\text { to }}^{\overline{4}} 25$

$$
\begin{aligned}
& 0.4 \\
& \text { common } \\
& \text { not seen }
\end{aligned}
$$

xenomorphic,

heteroblastic grains

common (same)

none

0.2

0.5

none

Extinction:

in all components plates parallel vein

Mode of

occurrence:

granoblastic
mosaics with
quartz

granoblastic mosaics with quartz

Plagioclase: the paragneiss contains only trace $q^{\prime}$ 's of plagioclase

Mafic Minerals

Sillimanite

; grain size:

Mode of

occurrence:

$0-2 ;<0.1 \mathrm{~mm}$ streaky buncles

within leucosome
$0-80 ;<0.1$ $0-25 ;<0.1$ and $v . f . B$. aggregates

Note: the sillimanbite within mobilizate I and adjacent melanosome is prograde (muscovite + quartz $-->\mathrm{K}-\mathrm{spar}+$ sillimanite + $\mathrm{V}$ )

Biotite

igrain size: hode of

occurrence:

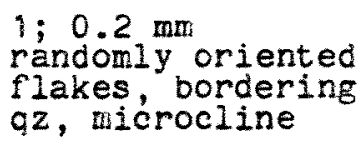

$5-50 ; 0.2$

oriented flakes

paralieling vein

$<5-15 ; 0.2(\max .1 .2)$

rancomily to oriented flake

Garnet

D; grain size: not seen not seen trace; 1 to $1.5 \mathrm{~mm}$
Mode of occurrence: garnet porphyroblastic growth/crystalization occurred during

not seen

not seen

trace; <1 to $1.5 \mathrm{~mm}$ migmatization II. Garnets are not seen in mobilizate I veins even though garnets may occur within the paleosome and mobilizate veins within the same hand sample. 
TABLE 6-3: Mineralogical characteristics of mobilizate I-paleosome.

CONCORDANT AMPHIBOLITE (thin sections ON-5-2, OS-1-5, OS-7-2)

Note: Melanosomes have not been identified for any generation of mobilizates in concordant amphibolite, probably as a result of the high colour index of the paleosome; fine grained, leucocratic paleosomes (ex. granite I) preferentialiy develop distinct melanosomes, since a relatively small degree of mafic enrichment is readily noticed.

Thickness $(\mathrm{mm})$ : mafics:

$\frac{\text { Leucosome }}{2 \text { to } 8}$

Plazioclase

Typical grain size: Zoning:

\section{Alteration:}

Myrmekite:

Mode of occurrence:

\section{Quartz} Typical grain size: Orientation: Extinction:

Mode of occurrence: Typical grain size:

$$
\begin{aligned}
& 0.4(\max .1 .0) \\
& \text { not seen } \\
& \text { absent } \\
& \text { absent }
\end{aligned}
$$

hypidiomorphic grains

$0.4 \dot{m}$ m
none
weakly undulose

polygonal to lobate mosaics with plag.
Paleosome

$25 \operatorname{tos}^{0.4} 45$

$$
\begin{aligned}
& 0.4 \\
& \text { rare but seen } \\
& \text { in ON-7-2 } \\
& \text { absent } \\
& \text { absent }
\end{aligned}
$$

hypidiomorphic to idiomorphic grains

K-Feldspar: absent in all components of concordant amphibolite.

Mafic Minerals hornblende ; grain size: Mode of

$\langle 1-2 ; 0.2 \mathrm{~mm} \quad 10-40 ; 0.4$

occurrence: granoblastic hypidiomorphic grains in both components

Biotite
B; grain size:
$0-1 ; 0.1 \mathrm{~mm}$
$1-40 ; 0.1$ to 0.8
Clinopyroxene: seen locally in mobilizate II $(\mathrm{ON}-7-\mathrm{F} 1 \mathrm{C})$ and in the amphibolite paleosome $(\mathrm{OSF}-1)$ 
2-Mobilizate IIa

Leucosomes generated in rocks of age groups I and II are subdivided on the basis of field occurrences into three chronologic categories. Mobilizate IIa consistently is seen to be segregated along flexural dilation zones related to $F 2 b$ folding of the predominant S2a schistosity. Mobilizate IIb veins cross-cut mobilizate IIa and S2a, following S2c slip cleavage surfaces axial planar to F2c refolding of F2b folds (Figs. 3, 28). Mobilizate IIc occurs as partly discordant, coarse grained pods, cutting mobilizates $I I a, b$ and intersecting foliations $S 2 a$ and S2c. Mobilizate IIa assumes many morphological varieties. Well developed melanosomes are usualiy present, except in cross-cutting veins, and where the mobilizate infiltrates rock layers (ex. brecciated or boudinaged dykes) of different lithology than its source paleosome (Figs. 30, 31, Plates $20 a, b)$. Leucosomes segregated in interboudin interstices developed during deformation IIa (c.f. Figs. 17, 18 and Plates 20a,b) probably represent the initial stages of migmatization II mobilization (Table 1).

i. Mobilizate IIa in Granite I

From a morphological point of view, mobilizate IIa material is best developed in granite I. As a paleosome, granite $I$ is very homogeneous, both from a compositional and textural stand. As a result, coupled with the consistently fine-grained nature of granite I, neosomes are clearly and unambiguously developed. Mobilizate IIa most commonly segregates as 0.5 to $10 \mathrm{~cm}$ thick veins in granite $I$, concordant to the S2a biotite-hornblende foliation (Plate 17a). Not uncommonly, these veins show pinch and swell structure (Plate 17b), or are ptygmatically folded (FIE. 24). Nelanosomes are well developed, usually 1 to $3 \mathrm{~mm}$ thick. Where veins are closely spaced, adjacent maleanosome may impinge upon one another, forming a "double restite" effect (Plate 17c). Cross cutting veins are rather rare; these usually lack a marginal melanosome, reflecting the mobility, and hence discordance, of the vein material (Plate 17d). 
Motilizate II most commony ocurs as concordant veins, with well developed marginal melanosomes. Given a concordant vein morphology, it is not always possible to relate the segregation to a particular structural dilation zone, since mobilization in large part occurred ouring F2b folding, which continued to fold the levcosome veins after flexuring the saz schistosity in which the mobilizate accumulated (c.f. Fig. 3). Concordant veins bounded by meianosomes indicate a direction of mobilization perpendicular to the length of the vein. Where mobilization parallels this schistosity, streaky neosomes develop, with melanosome material forming the core of $a$ leucocratic streak (Plates 19a,b). Mobility on a lareer scale typically results in cross-cutting relationships. This leads to the second effect of leucosome mobility: Iigrating mobilizates tend to recrystallize rock leyers of different lithology than their source paleosomes. A typical example of this is the presence of $1 \mathrm{~cm}$ hornblende porphyroblasts occurring in and along granitic mobilizates infiltrating amphibolite cykes in granitic host rock (Plates $14,20 a, b$ ).

Characteristics of mobilizate Ila-melanosome mineralogy in granite I paleosome are outlined in Table 6-1. However, since these segregations are exceptionally well represented in granite $I$, it is worthwile to delve further into the petrography of these components.

of particular interest is the presence of well developed mafic selvages separating the coarse grained mobilizate Ila from the homogeneous, fine grained granite I paleosone. Usually, the mobilizate juxtaposes a well defined melanosome always of the same, or sightiy finer, granulometry as the paleosome. A special case, however, is iliustrated in Fiz. 29, a sketch of a thin section of sample Oh-i-1 (c.f. Plate 17a). Here, the neosome shows distinct zoning, reflecting relative mobility of the mobile components constituting the leucosome. Modal analysis (Appendix 1) permitted ouantification of the each zone (Fig. 20) From this, it is seen that potash feldspar and plagioclase have migrated from the Iafic 
melanosome "Ma" zone inwards, toward the leucosome. As such, the mafic selvage "lia" is a quartz-hornblende-(plagioclase, biotite, opaque) rich assemblage, exemplifying the typical melanosome in granite I. Moving toward the leucosome, zone "Mb" is seen to be of similar granulometry as "Ma", containing, however, considerably less mafic minerals and quartz, and more plagioclase and potash feldspar, the latter being irreguiarly distributed. Certain portions of this zone are plagioclase-quartz assemblages, while other parts consist mostly of potash feldspar-quartz. Since this zone is fine grained, and contains minerals (plagioclase, mafics) which are poorly represented in the coarse grained leucosome, zone "Mb" is considered to be part of the melanosome (in view of its leucocratic nature, more appropriately a "restite"). The leucosome is essentially a microcline-quartz assemblage, which form mosaics with lobate contacts. Plagioclase forms fine grained, hypidiomorphic grains interstitial to the coarse grained microcline-quartz mosaics. The leucosome itself is zoned: quartz is segregated in the core of the mobilizate, forming a central, discontinuous vein.

The vein illustrated in Fig. 29 is typical of mobilizate II in granite $I$. In the general case, these veins do not show distinct zoning as seen in the present example, however, the leucosome-mafic selvage relations are consistent. With the exception of quartz, melanosomes are depleted in the leucosome vein minerals. Taken as a whole, the neosome mineralogy matches that of the paleosome, although, textural and granulometric parameters are dissimilar in the different components. No markedly desilicified zones were noted. However, Eiven the quartz-rich $(\leqslant 33 \%)$ nature of granite $I$, and the maximum neosome quartz enrichment of about $40 \%$ over and above this figure, it is not surprising that a precise source of neosome quartz is difficult to locate. Melanosomes are well developed in granite I simply because of the fine grained, homogeneous and leucocratic (mafics totalling 5 to $6 \%$ ) nature of the paleosome, and a five-fold enrichment of these same mafic minerals in melanosome seams. Conversely, one might expect 
that melanosomes would be relatively difficult to recognize in melanocratic paleosomes, for example, amphibolites.

ia-Mobilizate IIc: A Comparison with Mobilizate IIa in Granite I.

Metre-scale, lobate masses of coarse grained mobilizate locally cross-cut the foliation in the host paleosome. These pegmatoids typically have concordant offshoots bounded by well developed melanosomes (Plate 17c), indicating migration of a limited extent. Locally, these irregular masses are seen to cross-cut and fill noses of tight F2b folds (Fig. 28). "Inclusions" of folded host gneiss within the mobilizate show no evidence of dislocation and rotation. Since these masses of pegmatoid cross-cut mobilizates IIa and IIb, and are always of granitic compositon in granite I paleosomes, consistently with marginal melanosomes, these coarse grained mobilizates are considered to be products of migmatization II, and are labelled mobilizate IIc.

Determinations were made on melanosome and mobilizate IIc plagioclases from a typical sample of granite I (OS-1-2b; Plates 17c, 18). Since this sample has a $5 \mathrm{~mm}$ thick melanosome, distinction of plagioclases lying within the paleosome from those in the melanosome presented no difficulties. Melanosome plagioclases showing 010 albite twins consistently have maximum symetrical extinction angles of 8 to 9 (also seen in sample $\mathrm{ON}_{-1-1}$ ). Since these plagioclases are seen to have refractive indices exceeding those in adjacent quartz grains (Becke line test), a composition of An 28 is indicated from the Michel-Levy chart. Paleosome plagioclases, by the same method, are slightly more sodic (An 25). A $1 \mathrm{~cm}$ plagioclase crystal separated from the mobilizate IIa vein in this sample is seen to have refractive indices $\alpha 1.536, \beta 1.542, \gamma 1.544$, as determined by oil immersion. These indices correspond with a plagioclase composition of An 15 , markedly more sodic than plagioclase within the adjacent melanosome, from which the leucosome, in large part, was segregated. 
Although mobilizate IIc postdates mobilizate IIa veins, the morphological and compositional similarity between these neosomes indicates a common origin. The mobilizate Ila veins sampled have thinner $(<1 \mathrm{~mm})$ melanosomes than sample $O S-1-2 b$, therefore are iess amenable to melanosome plagioclase determination, since, under the microscope, it cannot be clearly distinguished where the paleosome ends and the melanosome begins.

Since mobilizate IIa leucosomes are best developed in granite I, it is worthwhile to summarize some of their features. Mobilizate IIa segregations typically are localized in flexural openings of S2a-schistosity. Consequently, vein type morphologies predominate; since deformation IIb developed no axial plane schistosity, mobilizates tend to occur near F2b-fold hinges, and are never seen to be axial planar to these folds. Mobilizate IIa segregations typically are coarse grained $(5 \mathrm{~mm})$, although tectonic granulation and recrystallization may diminish primary granulometry considerably. Melanosomes are invariably present. These consist of the same mafic minerals as seen in the paleosome, and may be (mesoscopically) thin (1 $\mathrm{mm}$ ) and sharply defined, or thicker $(5 \mathrm{~mm})$, grading diffusely into the paleosome. Coarse mafic clots are not uncommon in coarse grained mobilizates (Plates 17a,c). These clots consist of melanosome minerals, in various stages of alteration: hornblendes commonly are chloritized along cleavages. Cross-cutting relationships indicate that not all petrographically-similar migmatization II leucosomes were simuitaneous. Thus, mobilizate IIc leucosomes, may be distinguished from non-granulated mobilizate II veins (eg. coarse grained) by their typical mode of occurrence, accumulating as metre-scale pods cross-cutting paleosome schistosities and earlier-formed leucosomes. The fluid nature of mobilizate II leucosomes is demonstrated by discordant offshoots from melanosome-seamed concordant veins (Plate $17 \mathrm{e})$, and by mobilizate infillings seen in brecciated rock layers, of different lithology than the mobilizate's source paleosome. On the basis of samples $\mathrm{ON}-1-1$ and $\mathrm{OS}-2-1 \mathrm{~b}$, chosen for their well developed, 
thick melanosomes, migmatization II leucosomes contain plagioclases considerably more sodic than plagioclases in the adjacent melanosome. 
PLATE 17. Aspects of mobilizate II veins in granite I.

a. Sample ON-1-1. Mobilizate IIa concordant to the hornblende-biotite Sza foliation in the Eranite I paleosome. The well developed $1 \mathrm{~mm}$ thick melanosome consists of nomblende-biotite. The ieucosome is rich in microcline, with cuartz concentrated alone the vein centre. Note mafic clot (chloritized hornblende) in levcosome.

b. Pinch and swell in a mobilizate IIa vein, similar to oN-1-1. Location: OS-3.

c. Sample OS-1-2b. Diffuse, $5 \mathrm{~mm}$ thick, borderine pinch and swelled mobilizate IIc veins. Close proximity between the veins causes the diffuse melanosomes to juxtapose, formina a "double restite". Sample taken from concordant vein offshoots from a lareely discordant mobilizate pod, illustrated as plate 18.

d. Sample OS-16-1. Cross-cutting mobilizate IIa veinlet, culminating in a $2 \mathrm{~cm}$ pod. The absence of a melanosome here reflects the mobility of the leucosome material: it has migrated from its granite I source, at most $a$ few tens of centimetres distant.

e. Concordant mobilizate IIa veins with well developed melanosomes. The vein to the right of the amphibolite IIb dyke has a discordant offshoot: this leucocratic material traverses the dyke, indicating that concordant as well as discordant mobilizate IIa segregations are mobile-end fluid-to a greater $(\mathrm{cm}$ to $m$ ) or lesser (mm) degree. 
PLATE $17 \mathrm{a}$.

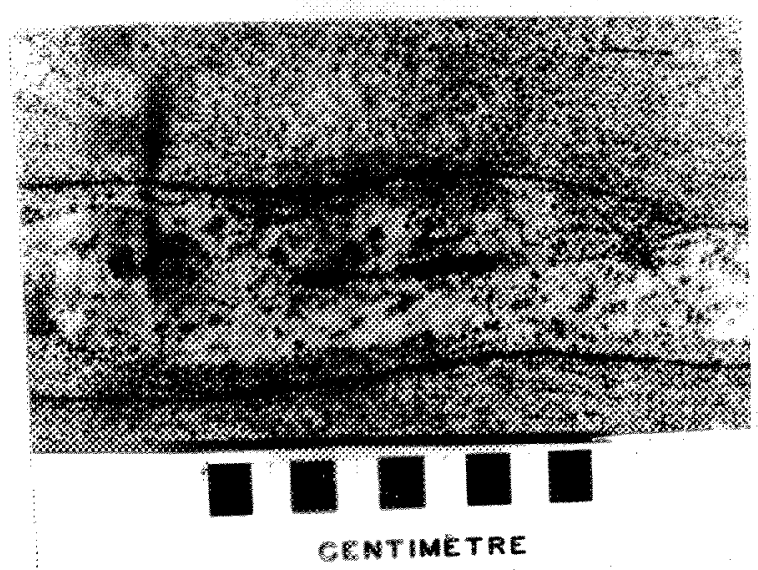

PIATE $17 \mathrm{~b}$.

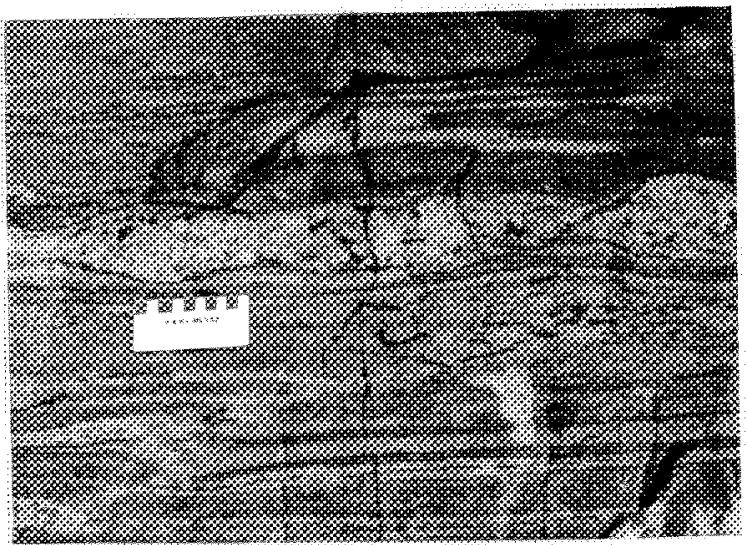

PIATE $17 \mathrm{c}$.

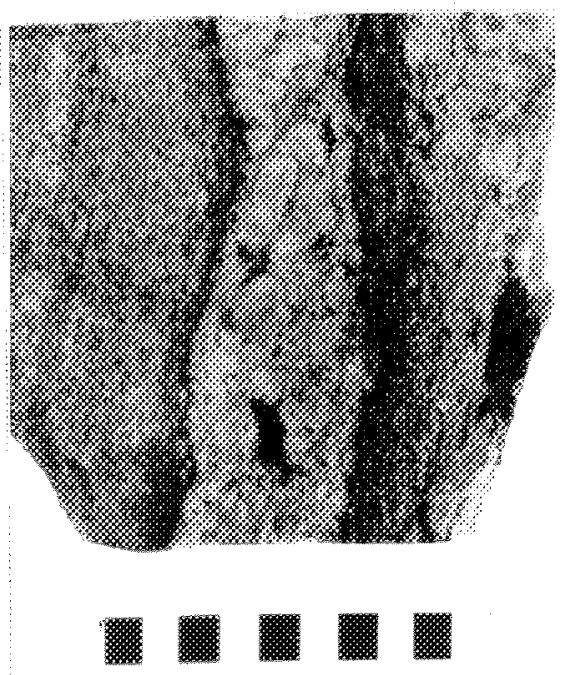

G 
PLATE 17d.

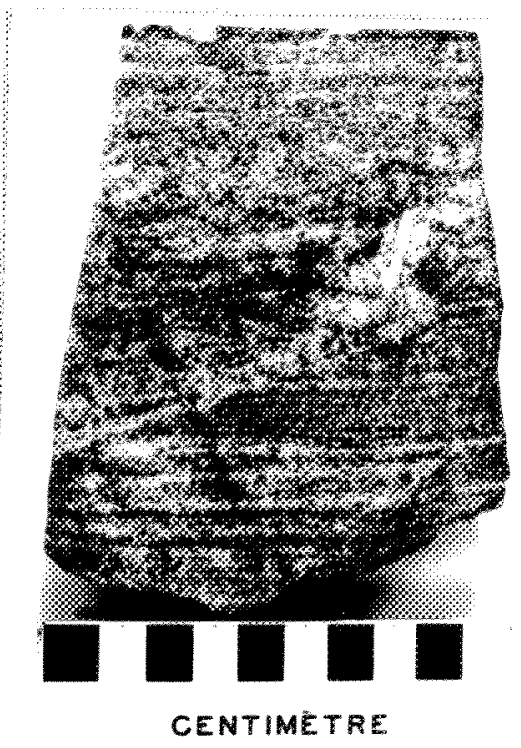

PIATE $17 e$.

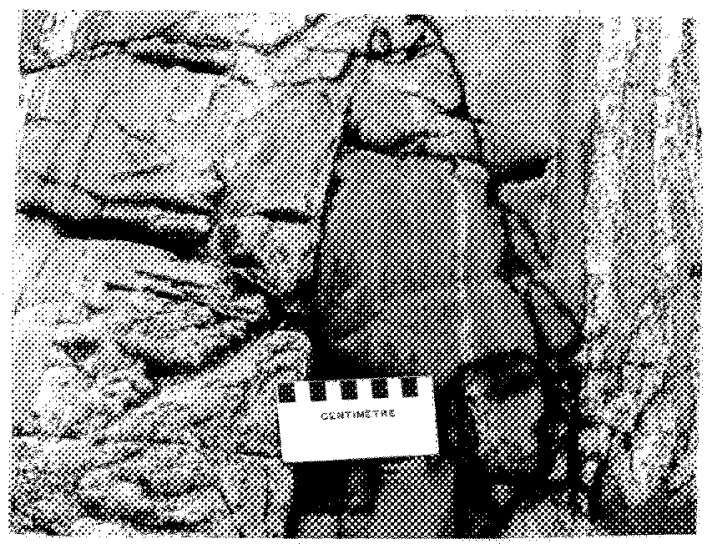


PLATE 18.

Ketre-wide irregular pod of coarse grained (microcline crystals attain $3 \mathrm{~cm}$ ) mobilizate IIc, in grenite $I$. With respect to the biotite foliation in the granite I (S2a), the bulk of the mass is discordant; bere melanosome material is thin and discontinuous. However, concordant cm-scale offshoots have thick $(5 \mathrm{~mm}$ ) melanosomes: the sample illustrated as Plate $17 \mathrm{c}$ was taken from one of these offshoots. Location: OS-2.

EICURE 28. (following page)

Discordant to subconcordant lobate masses of coarse krained $(2 \mathrm{~cm})$ mobilizate IIc in granite $I$. The leucosomes cross-cut both F2b folos (upper right, no axial plane cleavages) and mobilizate IIb-filled S2C shear surfaces (bottcr of map). Inset shows the relation of $S 2 \mathrm{C}$ and mobilizate IIb localization to incipient F2C refolding of isoclinally F2b folded amphibolite IIb dykes 


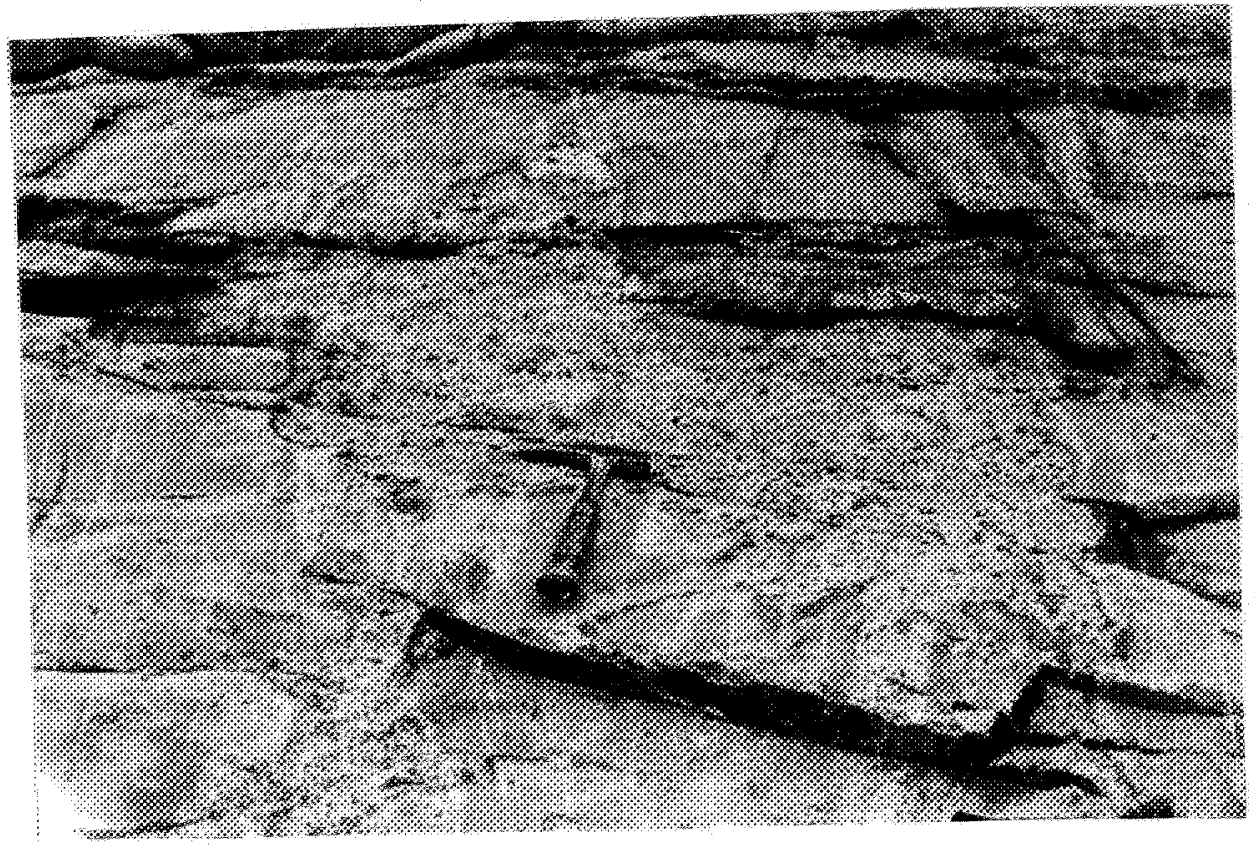

PLATE 18. 


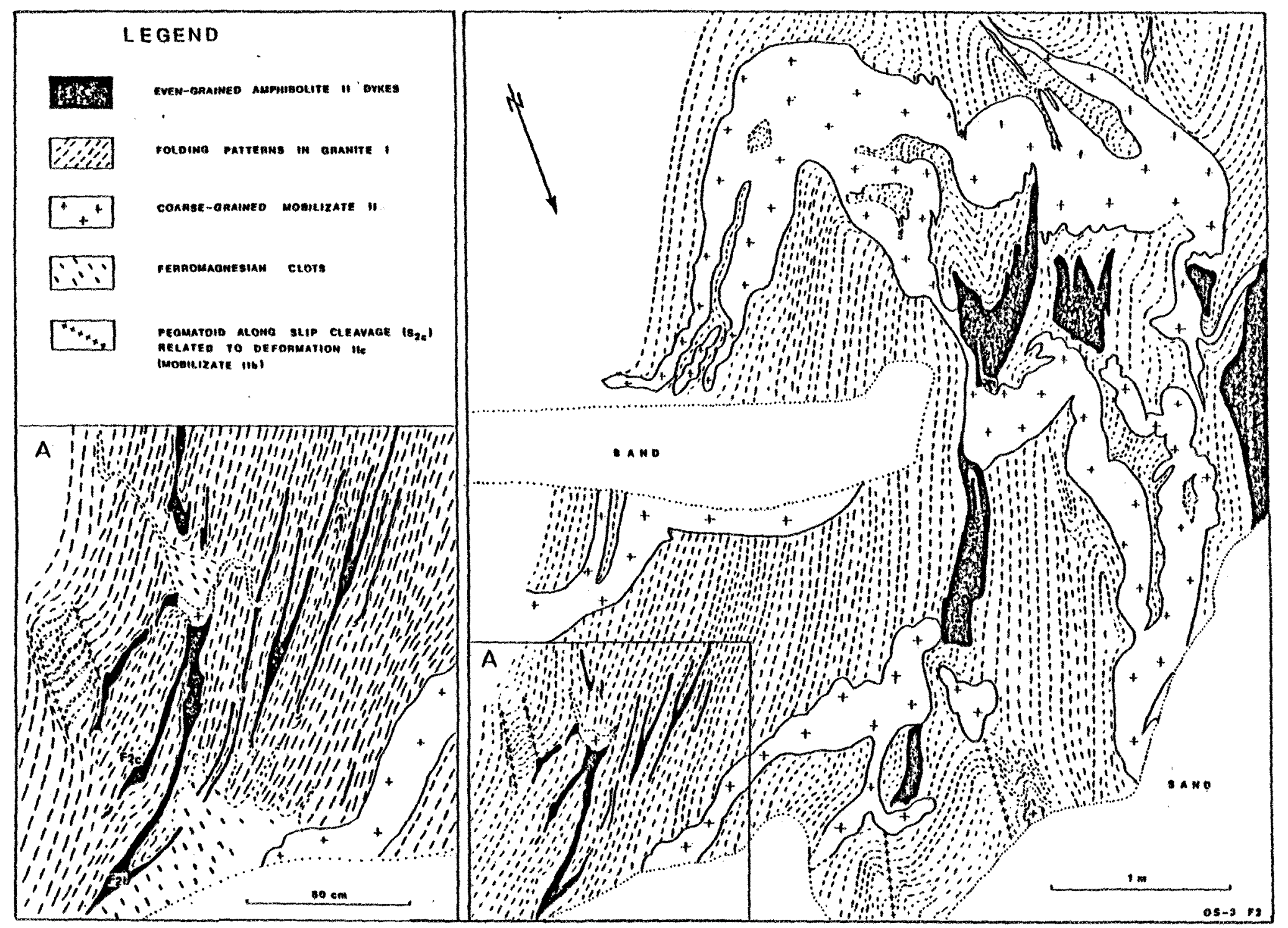




\section{FLATE 19.}

a. Hido aspect of melanosome-cored mobilizate Ila streaks in wranite $I$, at of-l. Leucosome pobilization largely paralleled the streak (and S2a). Tape in centinetres.

b. Hand sample on-1-10. Cross section or mobilizate IIa streaks show in Plate 19a. Scale: cu.

\section{PLATE 20.}

a Coarse grained roblizate Ila filing unterstices betheen boudinaged dyke amonibolite IMb. The mobilizate is granitic, and contains co horrblende clots due to reation with the amphbolite. The amphibolite is concordant to the S2a foliation in the grantite i host, the paleosone source of the mobilizate. Note the concordant mobilizate Ila vein in the granite (above ayke) with harginal thelanosome. Location: os-26.

b. Mooilizate Ma, grantic in composition, inplltrating the but of an isolated dyke amphibolite IIb boudin, in srantte I. The boudir, as such, has the same techanical properties as an inclusion: under confining stress, the mobilizate generated in the grandte I accumulates in the low pressure terminal region of the boudn, inflitrating the boudin's cleavage (S2a), and recrystallizing amphiboles. Same outcrop as plate $20 a$. 
PIATE 19a.

PLATE $19 \mathrm{~b}^{\circ}$
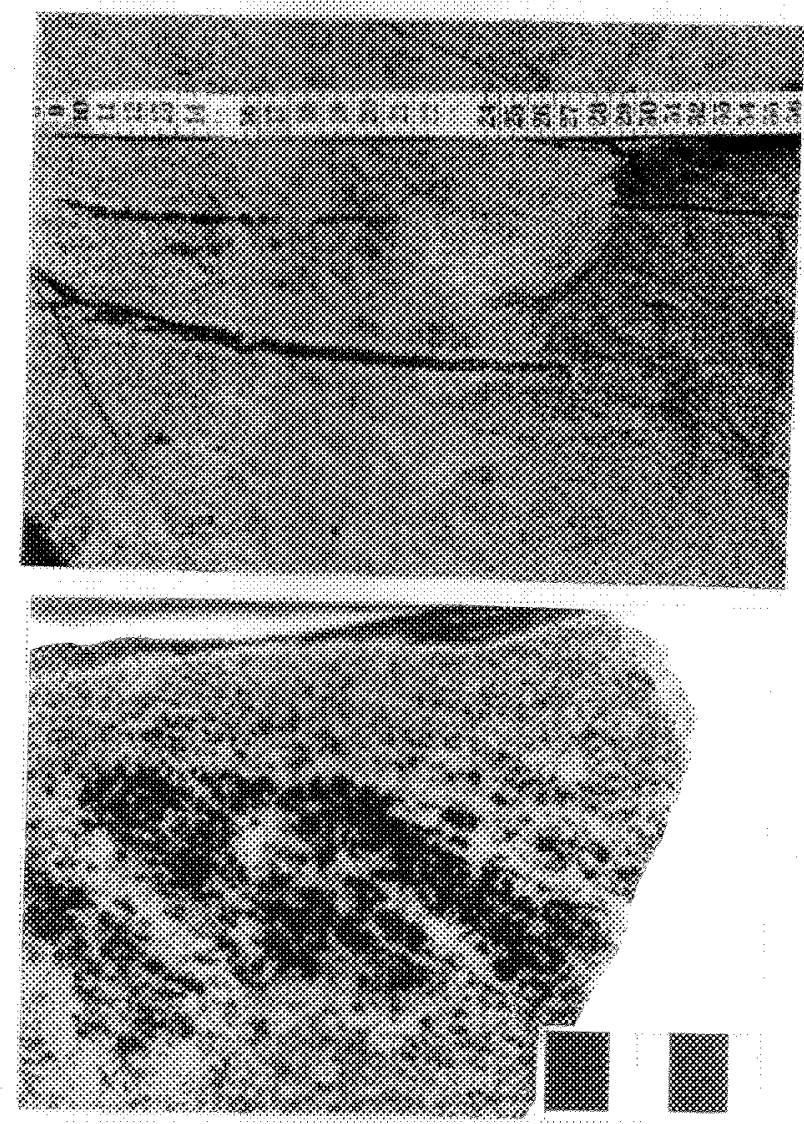

PIATE 20a.

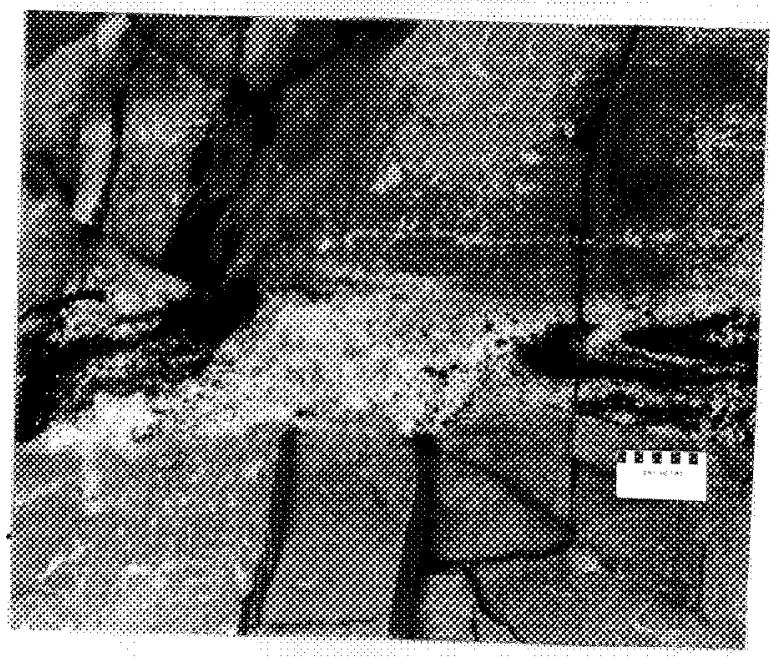

PLATE $20 \mathrm{~b}$.

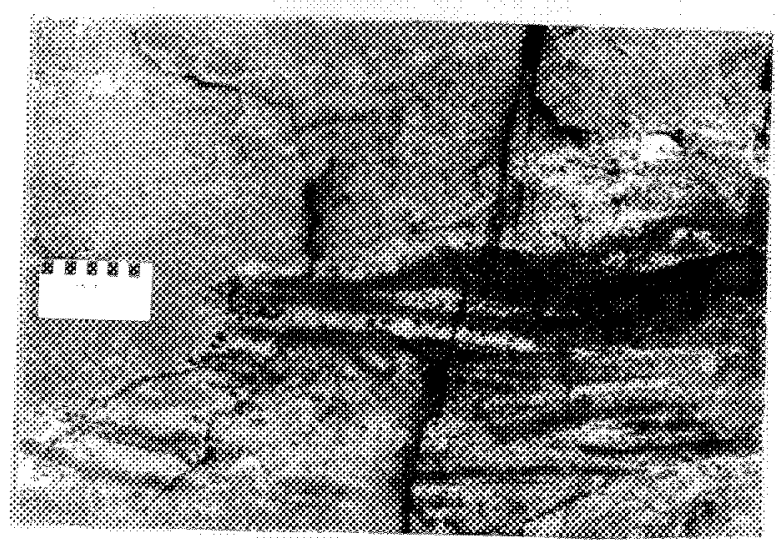


FIGURE 29.

Sketch of part of thin section ON-1-1 (c.f. Plate 17a): mobilizate IIa in granite I. The coarse grained leucosome contains a central quartz (white)-rich vein. Quartz forms lobate mosaics with microcline (stippled). The melanosome is subdivided into a plagioclase-microcline-ouartz-mafic bearing zone (Mb), equally fine grained as the adjacent melanocratic seam (Ma), consisting of recrystallized quartz plates and hornblende (minor biotite, opaques) with lesser plagioclase and microcline. Plagioclase represented by hatchine; mafics are black. Zone Mb is usually absent: plafioclase tends to form sporadically occurring megacrysts instead of segregating in a marginal zone (Mb). The plagioclase distribution of the $M$ zone is extremely variable, as indicated by the dashed line in the quantitative profile. The exceptional degree of zoning in this example reflects relative mobilities (ouartz>microcline>plazioclase; mafics are essentially imobile) of the mineral components of the neosome. Zone $\mathrm{Mb}$ is included as part of the melanosome despite its leucocratic nature because of its granulometry, enrichment in plagioclase (depleted in this case in the leuccsome) and higher mafic content. Compositional data based on point counts listed in Appendix 1. Note that problems in distinguishing between different neosome components on a microscopic scale tend to compromise the accuracy of these data. 
Paleosome Ma $\mathrm{Mb} \longrightarrow$ Leucosome Mb Ma Paleosome
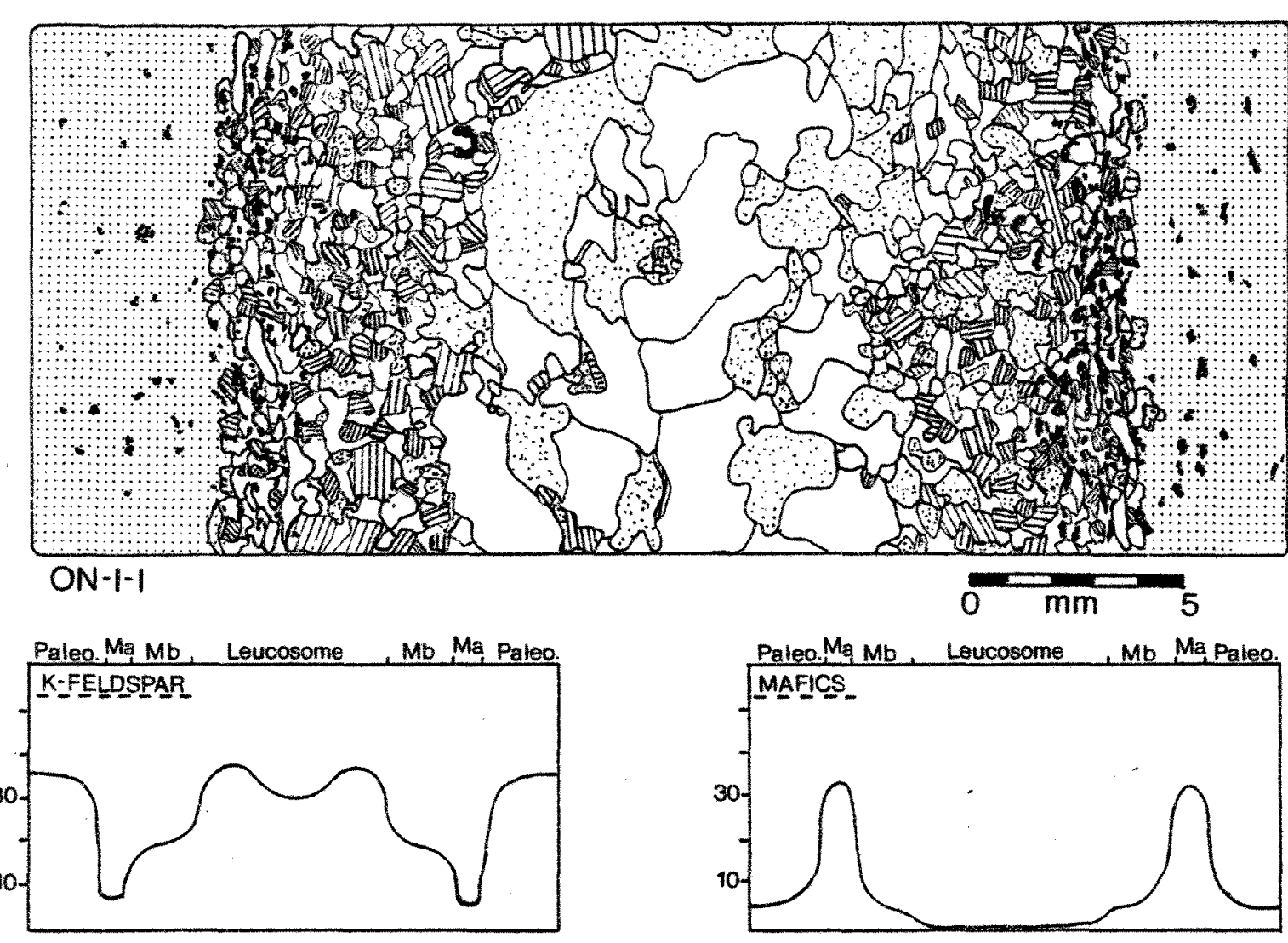
PLATE 21.

"Granitic" composition of mobilizate IIa in franite. I. The leucosome consists of grid-twinned microcline, interstitial ouartz (white, even grey, black) and small amounts of plazioclase (twinned, at left in photo). Stained thin section ofv-4-1. $X-n i c o i s:$ Bar: 2 mo. 


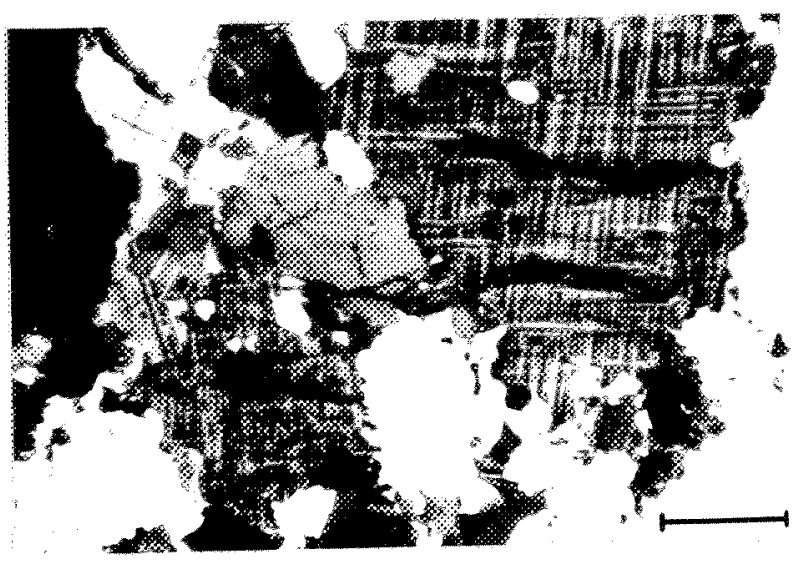

PIATE 21. 
ii. Mobilizate IIa in Paragneiss.

Mobilizate IIa in paragneiss typically occurs as 1 to $5 \mathrm{~cm}$ thick, melanosome bordered leucocratic veins (Plate 16a). Diffuse mobilizate patches not uncommonly truncate tightly folded mobilizate I veins (Plate 16a), however, metre-scale discordant lobate-shaped segregations (mobilizate IIC), as seen in granite I, were not observed in the paragneiss sequence. The large volumes of closely spaced leucocratic veins in the banded paragneiss make distinction of different vein structures difficult. However, where individual veins are more widely spaced, these features may be observed. Plate 22a shows pinch and swell structure in an isolated leucosome in paragneiss. Similar veins in the same outcrop contain small amounts of garnet and cordierite. Boudinaging of primary compositional layering (beding), where distinguishable, acts as a local control of mobilizate localization. Plate $22 \mathrm{~b}$ shows pink, microcline rich mobilizate IIa material diffusely infiltrating the pinched dilational zone of a $10 \mathrm{~cm}$ thick boudinaged quartzite interbed in biotite paragneiss.

As in the case of mobilizate I, leucosome-paleosome relations are difficult to establish for mobilizate IIa veins in the paragneiss. Despite the absence of homogeneous paleosome, the complementary mineralogy seen in leucosomes and the adjacent gneiss demonstrates an in situ origin for mobilizate IIa. Similarly, melanosome minerals, chiefly sillimanite and biotite, locally with garnet, also occur in the adjacent gneiss, identifying the latter as the paleosome source of the mobilizate.

As seen in Table 7-2, both the paleosome and mobilizate segregations are rich in microcline and quartz; plagioclase is a minor component. Compared to mobilizate I veins even within the same hand sample, mobilizate IIa veins in paragneiss are always coarser grained (ex. $2.5 \mathrm{~mm}$ vs $0.5 \mathrm{~mm}$ ), and tend to contain a higher 
TAELE 7a: Principal textures of granulite-grade pneisses (after Barraud, 1977)

\section{Primary}

a. Granoblastic no deformation or recrystallization effects. May be seen

b. Inequipranular in undeformed anatectic mobilizates

2. Secondary

(overprinting of primary textures $1 a, b$. Resulting texture is a function of the degree and mechanism of deformation and recrystallization)

A. Gneissic cataclastites

a. mortar texture: < $10 \%$ of grains/grain volumes are recrystallized (recrystallized portion consititutes "mesostasis" usually consisting of $0.1 \mathrm{~mm}$ grains). Mesostatis surrounds porphyroclasts.

b. augen texture: 1 to $50 \%$ recrystallization. Mesostasis isolates lens-shaped porphyroclasts

c. flaser texture: 50 to $75 \%$ recrystallization. Quartz forms plates partiy enveloping lens-shaped porphyroclasts.

d. blastomylonite texture: (platy granoblastic) Recrystallization masks previous mylonitic texture. Ouartz plates in an equigranular mesostasis wrap about lenticular porphyroclasts.

B. Secondary granoblastic textures

a. heterogranular textures: 10 to $80 \%$ porphyroclasts; 90 to 20 \% mesostasis.

b. equigranular textures: < $10 \%$ porphyroclasts; > 90 mesostasis. Mesostasis forms mosaics having straight to lobate grain contacts.

C. Blastotectonic textures: intermediate betwen A. and B. (above). Quartz forms elongated masses, but does not attain a degree of stretchine to define plates or augen wrappings. May be:

a) heterogranular

b) equigranular

Note: Barraud's definition of the term "granoblastic" is at odds with its common definition, that is, an equigranular metamorphic texture, representing a high degree of tectonic recrystallization. 
TABLE 7b: Paleosome and in-situ mobilizate textures, old Gneiss Complex

\section{Mobilizate I Mobilizate II Mobilizate IIb Paleosome}

Dyke amphibolites:

IIc
IIb
IIa
uncorrelated (pre-IIb)
granitic dykes
Granite IIb
Granite IIa and
charnockitic gneiss
Granite I
Pelitic Paragneiss:

$\begin{array}{ll}-1 \mathrm{a} & 1 \mathrm{a} \text { serr } \\ \cdots- & \mathrm{NE} \\ \cdots & \mathrm{NE} \\ \cdots & 1 \mathrm{a}\end{array}$

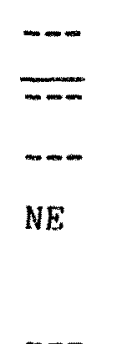

$2 B b$ str.

$2 B b$ str.

2 Ba str. /serr.

2Ba str./serr.

2Cb 1ob. 2Aa, 2Bb lob to 2Ca,b 1ob.-str. $2 \mathrm{Cb}$ lob.

2Bb $10 \mathrm{~b}$.

2Ba $10 \mathrm{~b}$.

NE

Concordant amphibolite

2Bb $10 \mathrm{~b}$.

$2 \mathrm{Ba} 10 \mathrm{~b} .-\mathrm{str}$.

NE

$1 \mathrm{a}, 10 \mathrm{ca} 11 \mathrm{y}$

$1 \mathrm{a}$

2Bb lob-str.

$2 B b$ lob.-str.

2Bb str.

SYMBOLS: $-\overline{\mathrm{NE}} \quad \begin{aligned} & \text { not present } \\ & \text { not examined }\end{aligned}$

Grain contacts: str. (straight)

serr. (serrate)

1ob. (1obate) 
PLATE 22.

a. Pinch and well structure in discontinuous moblizate tia veln, in the St. Fuigence parapelss sequence (Location: on-3). Wote the well developed biot ite melarosome. Thls paleosome is the most homogeneous seen in paragneiss winin the study area. Even 30 , thin (< 5 mhe mingtization-related layering can be seen. mootizate IIa veins.

b. Sample OS-11-8. A $10 \mathrm{~cm}$ quartzte bed shows pinch and swell structure. Potash feldspar rich moblizate lie infiltrates the diation zone in the cuartzite bed, the leucosone originating in the biot 1 te-garnet parameiss host of the quartzite interbed.

PLATE 23.

a. Min section On-2-4a. Moblifate II in sillimanite-biotite paragneiss. The moollizate is rich in soid-twinged icrocine and bead-pertitic potash felaspar, not uncomony retaing relicts of grid twins. Fdges of potash feldspars show mortar texture. At lower right of photo, note the presence of thin films of twinned aloite mantling the perthite where contacting interstitial plagioclase (in photo: black, with thin white twins). Sar: 1 prin.

b. Thin section ON-2-4b. Mobilizate II in sillimanite-biotite-carnet paragneiss. Quartz (o) is lobate, and interstitial to merocline (m). Bar: 1 mo

note: mobilizate Ila is invariably coarser areined than dobilizate veins occurring within the sane rock. Compare the tranulonetry of the above photomicrographs gith Plates 15b,c showing mobilizate vein waterial from the sare samples illustrated above. 
PLATE $22 a$.

PIATE $22 \mathrm{~b}$.
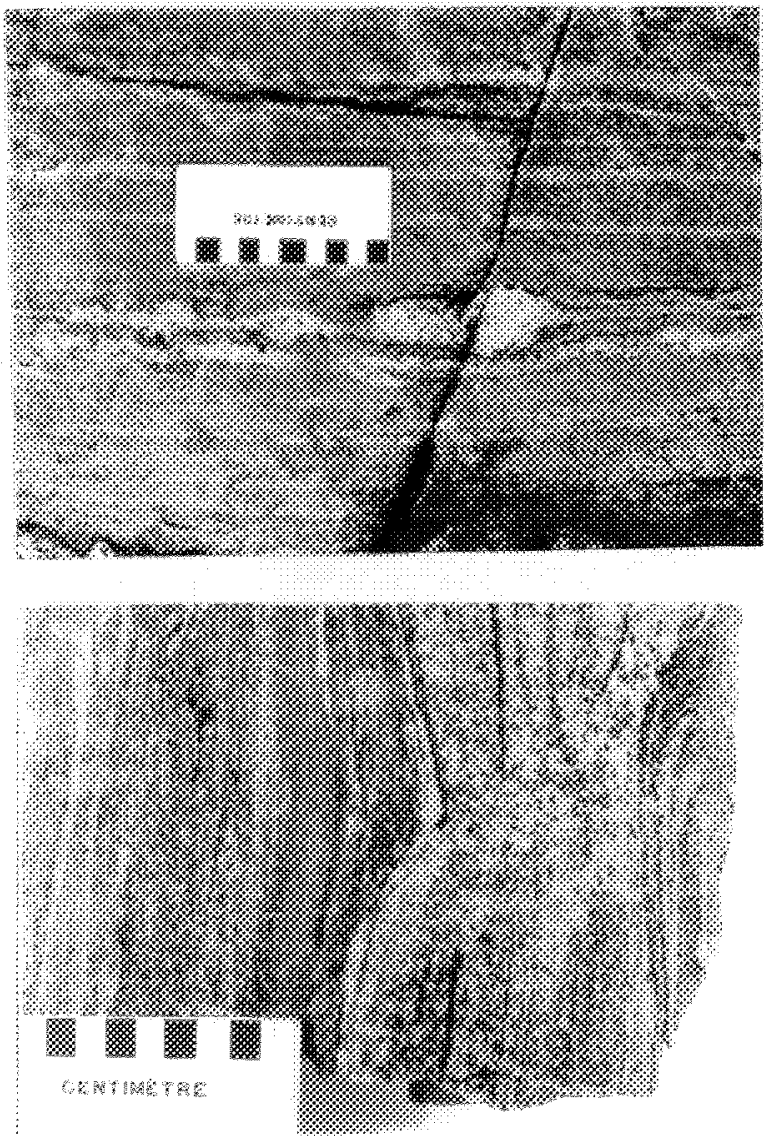

PLATE $23 a$.
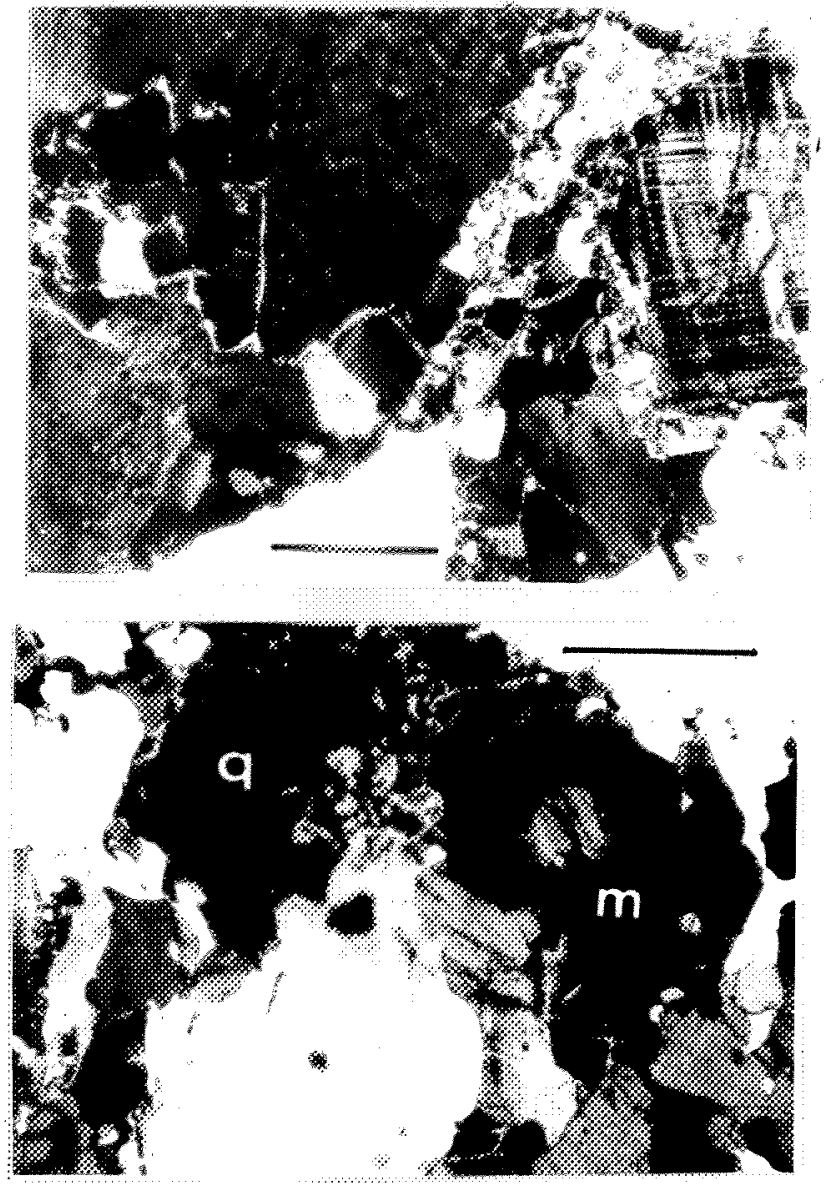
microcline:quartz ratio. In this material, all mineral species are xenomorphic, except for small quantities of hypidiomorphic plagioclase. Mortar texture may be well developed, and microcline may be mantled by thin $(0.05 \mathrm{~mm})$ twinned albite films, where contacting interstitial plagioclase (Plate 23a). Microcline also may exsolve plagioclase (untwinned), forming bead and string perthite (Plate 33a). Where not granulated or recrystallized, quartz occurs as lobate to serrate patches interstitial to microcline (Plate $23 b$ ). Quartz rareiy defines an oriented fabric in these veins.

iil-Mobilizate IIa in Concordant Amphibolite

Dccurrences and mineralogy of mobilizate IIa in concordant amphibolite differ markedly from that in either granite $I$ or paragneiss. Although mobilizate Ila commonly segregates as veins in concordant amphibolite, its most typical occurrence is as interboudin accumulations, This results from the banded, heterogeneous nature of the unit: individual bands ranging from 1 to $>30 \mathrm{~cm}$ characteristically show pinch and swell along their length. Mobilizate IIa segregates in the interboudin dilational zone, sometimes partly wrapping about either boudin, and following $S 2 a$ in the boudinaged layer, giving a "spider-like" morphology (Plate 24a). Figure 31 traces the development of this structure, all stages of which are seen in outcrop.

In one location $(\mathrm{ON}-7)$, the concordant amphibolite is flecked with 1 to $10 \mathrm{~cm}$ long quartzofeldspathic streaks, many containing mafic cores up to $4 \mathrm{~cm}$ across (Fig. 22, Plate 24b). Although this flecky amphibolite, occurring as a concordant band some $4 \mathrm{~m}$ wide, borders in part considerable volumes of granite III within the concordant amphibolite (Fig. 22), these leucocratic streaks predate the granite. This is indicated by the fact that the bulk of concordant amphibolite 
bordering the granite III is devoid of mafic cored leucosomes, along with the fact that the granite III cross-cuts the S2a schistosity that is in part defined by these streaks. The granite itself is unfoliated. Note also that irregular networks of pegmatitic mobilizate III postdate the granite III, hence the streaks are not a product of this pegmatitic stage of migmatization III. Considering the medium grain size and the absence of $F \mid$ folding, these streaks are inferred to be products of migmatization II.

As in the case of mobilizate I, products of migmatization II are always trondhjemitic in concordant amphibolite. Petrographic features of mobilizate IIa are outlined in Table 8-3. Compared with mobilizate I veins in the same outcrop or sample (ex. ON-5-2), mobilizate IIa is somewhat coarser grained $(-1.5 \mathrm{~mm}$ vs $0.5 \mathrm{~mm})$, and may have a higher quartz:plagioclase ratio (Appendix 1).

Despite the large volumes of mobilizate IIa that may occur in concordant amphibolite (Plate 24c), melanosomes are not seen. Neither is there any change in paleosome mafic mineralogy approaching leucosomes, as is the case where trondhjemitic (Plate 36) to granitic (Fig. 35) mobilizate III pegmatites intrude concordant amphibolite. In the latter cases, the amphibolite has been metasomatized; pegmatites are enveloped by biotite rich seams.

Variations in paleosome mafic mineralogy bordering mobilizate IIa segregations in different concordant amphibolite outcrops reflect the same variations in hornlende:biotite ratios seen throughout the amphibolite sequence, in the absence of leucosomes. With the exception of allochthonous pegmatoids (ex. migrant granitic mobilizate II, or mobilizate III pegmatites), leucosomes in concordant amphibolite do not influence either the mineralogy or the percentage of mafic minerals in the adjacent paleosome. 
Unlike tobilizate IIa in granite $I$, leucosomes in concordant axphibolite do not commonly bear sefic megacrysts, altered and recrystalizized equivalents of the same aafic minerals as in the melanosome and paleosome (ex. Plates $17 a, b, c$, ). The flecky gneiss ilustrated in Plate 24 a is noteworthy insofar as the aafic cores of the leucocratic streaks consist of clinopyroxene-e mineral not seen in the adjacent amphibolite. The eneiss consists of typical concordant amphibolite, foliated ano granoblastic textured, with about 40 to $45 \%$ subidiomorphic green hornblende, 50\% plagioclase, 4\% biotite, $2 \%$ opaques, and trace percentages of quartz and apatite. The quartzofelospathic streaks consist of plagioclase and ouartz. Unlike the very fresh plagioclase in the gneiss, the leucosome plagioclese shows incipient saussuritization. The ouartz and feldspar in the leucosome is much coarser grained than that in the gneiss: here crystals up to $14 \mathrm{~mm}$ across are seen. The small (1\%) amounts of biotite and hornblende occurring in the leucosome as $0.5 \mathrm{~mm}$ scattered grains show no apparent signs of recrystallization. Trace percentares of opaques and apatite are also seen.

The wafic core of the leucosome consists of a central 1 to $3 \mathrm{~cm}$ aggregate of clinopyroxene crystals up to $6 \mathrm{mb}$ across, in part mantled by a sieve-like intergrowth of green hornblence, pseudomorphic after the clinopyroxene, and quartz. This mantle is up to $3.5 \mathrm{~mol}$ wide; the hornblende mimics the pyroxene cleavage, and contains variable amounts (15 to $60 \%$ ) of fine grained $(0.05$ to $0.5 \mathrm{~mm})$ irregularly shaped quartz grains (Plate 25). Triple point junctions are not uncommon where several quartz grains juxtapose. In places, the pseudomorphic hornblende passes directly into the gneiss matrix hornblende, showing amphibole cleavage, the gradation being optically continuous. The central clinopyroxene core contains cleavage controlled actinolite (uralite), fibrous and pleochroic from greenish yellow to yellowish brown. The actinolite is veriably altered to yellowish green chlorite, having enamalous blue birefringence. A small amount of quartz occurs in the clinopyroxene aggregate. The clinopyroxene 
PLATE 24. Aspects of mobilizate II in concordant amphibolite.

a. "Spider"morphology mob111zate Ira filing dilation zone on a boudinaged 15 ca thick melanocratic layer in concordat amphibolite. This is an intermediate stage of development of the morphology; in rirore advanced stases (Fig. 30), the reobilizate wrap about the boudins, and inflltrates the schistosity in each. Location: On-5. Quarter-dollar gives scale.

b. Flecky melss: concondant auphbollte with mobilizate ITa streaks, paralleling S2a. Mafte cores consist of elinopyroxene marginally replaced by pseudoworphic green hornblende with ouartz intergrowths (c.f. Plate 25). Leucoeratic bulk of each flak is. as In ali mobilizate is and lia,b material, trondhjeritic (plasioclase composition not implied) in concordant amphibolite.

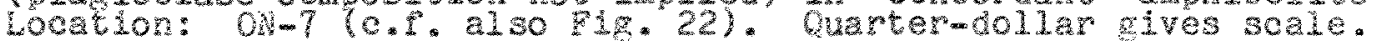

c. Large volumes of vein-moblilzate IIa in concordant amphibolite. Pen follows an $\$ 20$ straln slip surface, filled by mobilizate IIb. Note the mediur arain size (2 to'3 mal of the leucosome: mobilizate I is always finer grained $(0.5 \mathrm{~mm})$. location: os-10.

\section{PLASE 25.}

Matic core of moblizate II from "lecky"concordant anphibolite (c. Plate 24b). The leucosome portion of the levcosone is a plagioclase -quartz assemblage. The mafic core consista of clinopyroxene (opx), partly ohloritized and uralitized along cleavages. The ureinal portions of the clinopyroxene are pseudonorphically replaced by hornolende (hbl) with quart. (white) intergrouths. The pseudomorphic hornblende thay pass into paleosone homblende (hol, dark krey) with complete optical continuity. Thin section of-7-F1c. X-nicols. Refer to Fiz. 22 for sample location. 


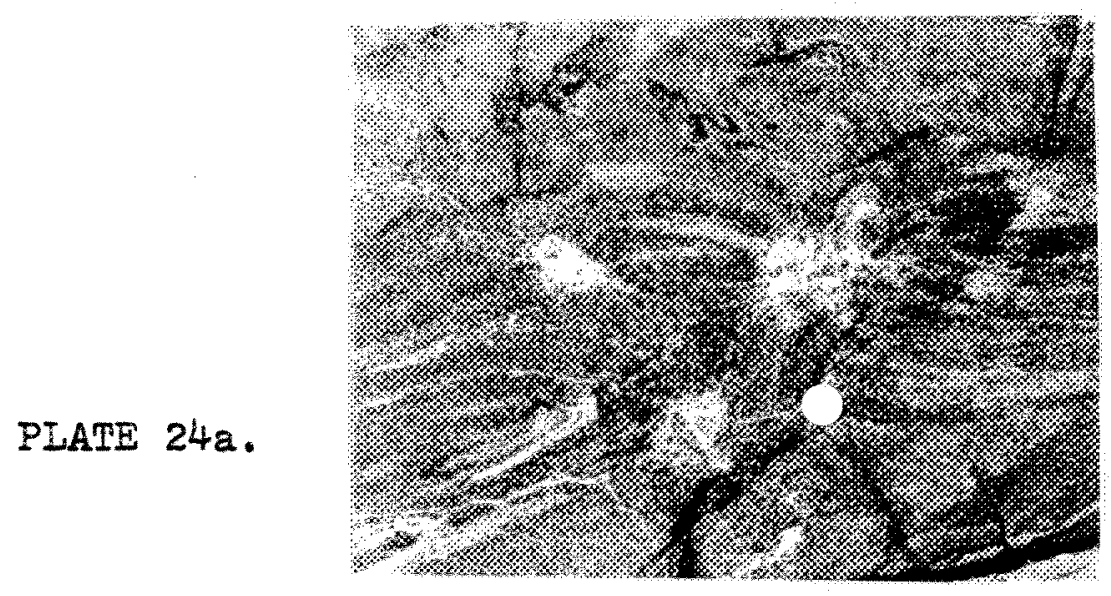

PIATE $24 \mathrm{~b}$.

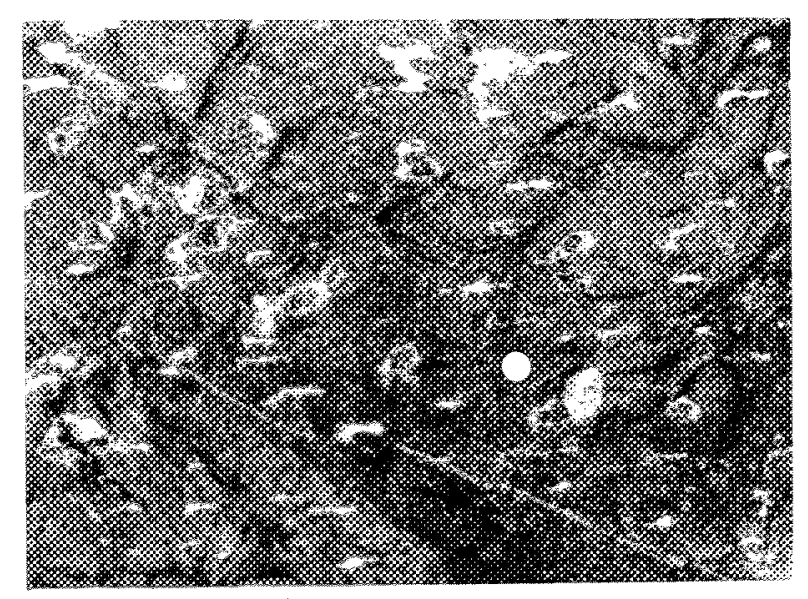

PIATE 24c.

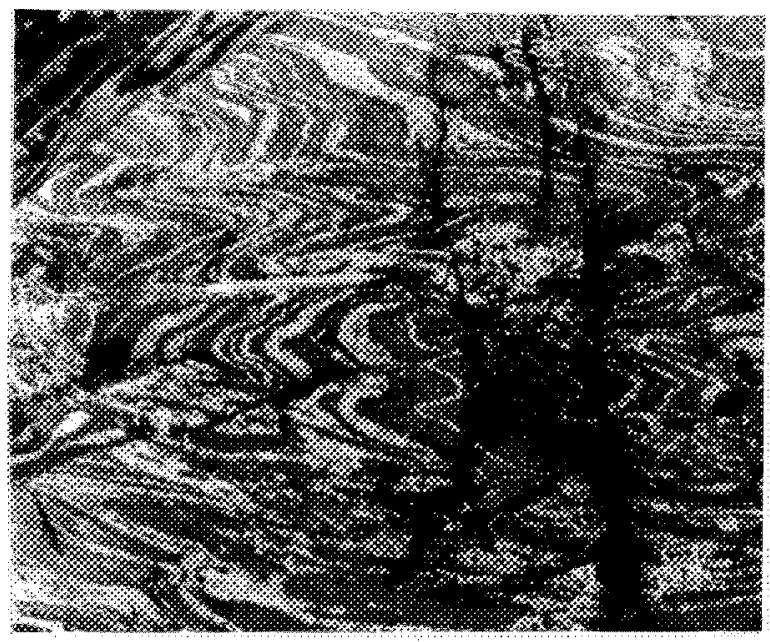




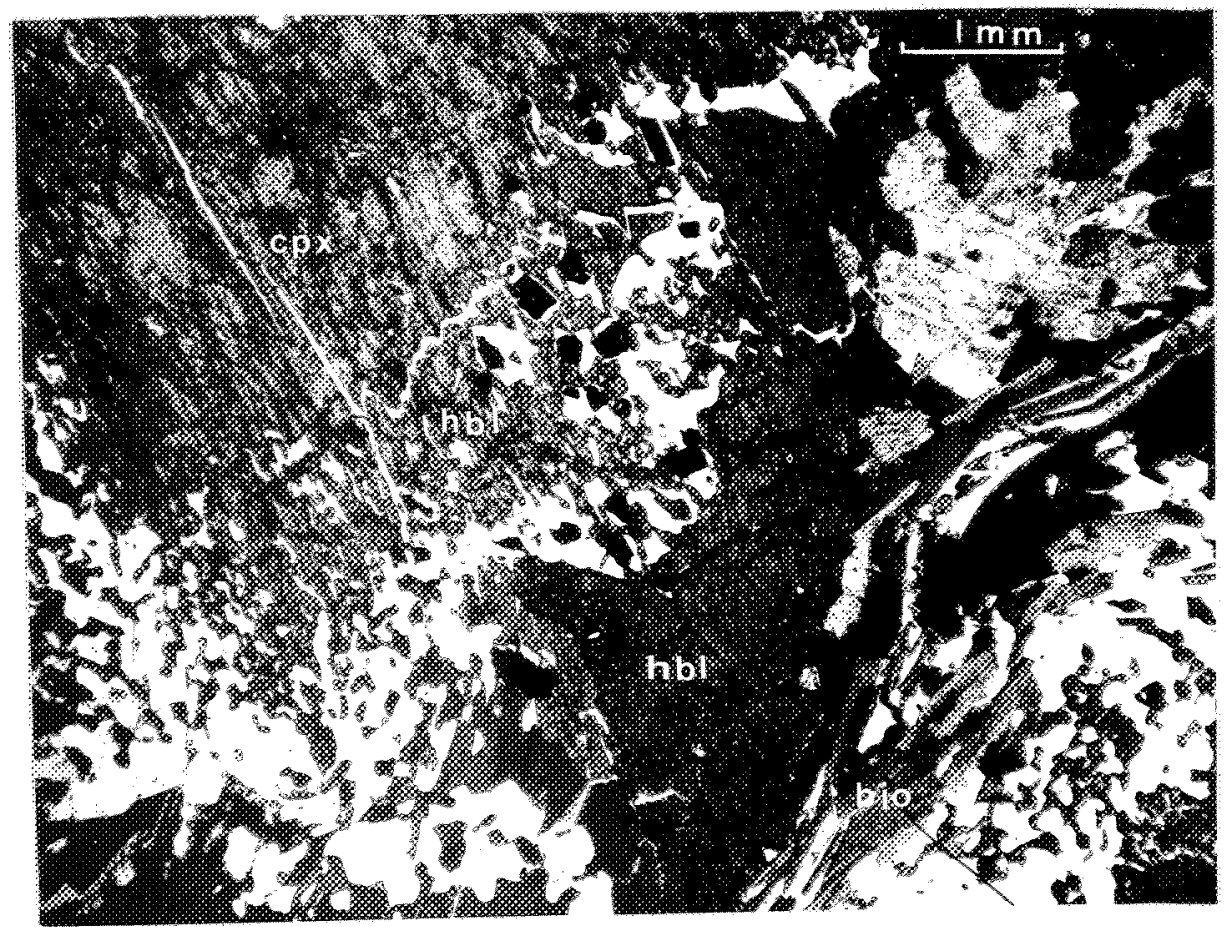

PIATE 25. 
EIGURE 30.

Stages of development of "spider" morphology, typical of mobilizate Ila as found in interboudin dilation zones in concordant amphibolite. All stages of developrent are seen in the amphibolite. Mobilizate IIa veins may, eventually, partly wrap about both boudins on either side of the dilation zone. Sketch after Wegmann, 1963, Fiz. 13). Compare with Plate $24 a$.

\section{PLATE 26.}

Photomicrograph of mobilizate IIa "spider morphology" from banded concordant amphibolite. In the sample (OS-5-2) studied this material has a higher ouartz:plafioclase ratio than mobilizate I veins, cross-cut in the sample by mobilizate II. The mobilizate II is also coarser grained than the mobilizate I leucosomes (compare with Plate $15 \mathrm{c}$ ). Modal compositions for the sample are represented on Fig. 37. Plagioclase is twinned, quartz is white, even grey, back (extinct). At right of photo are hornblendes, unaffected by the mobilizate. Bar: $1 \mathrm{~mm}$. 
Stages of development of "spider" morphology, typical of mobilizate IIa, as found in interboudin dilation zones, in concordant amphibolite (heterogenous)

AII stages of development are seen in the amphibolite. Mobilizate IIa veins may, eventually, partly wrap about both boudins on either side of the dilation gone.
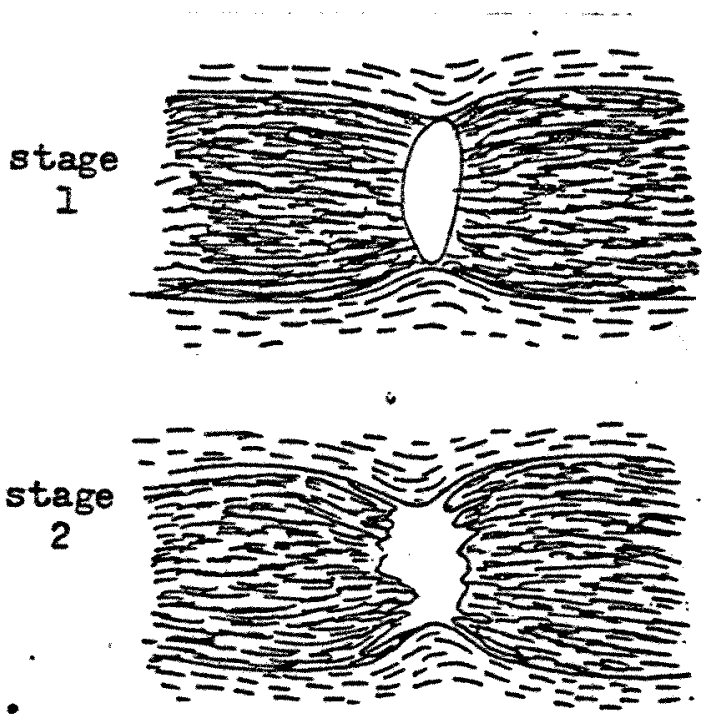

FIGURE 30 .

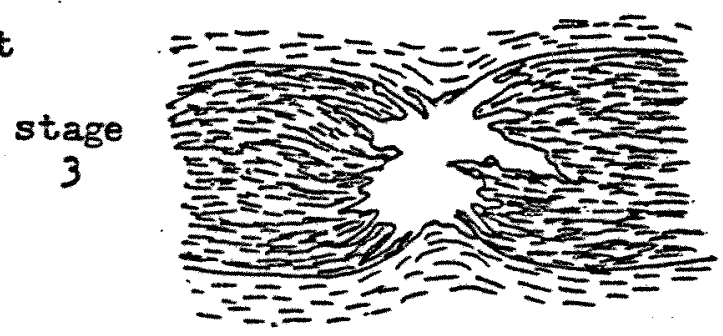

PIATE 26.

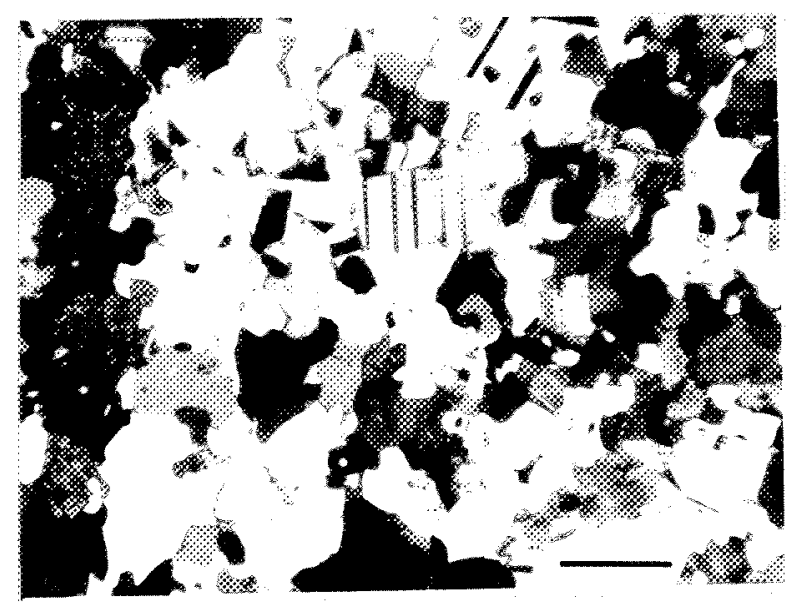


probably formed under the same conditions and at the same time as the rest of the leucosome, with subsequent marginal inversion of the pyroxene to form pseudomorphic hornblende with bleb-like quartz intergrowths.

iv-Mobilizate IIa in Granite II

Nobilizate IIa in streaky textured granite IIa and charnockitic gneiss forms diffuse, ill-defined subconcordant veins and patches. Individual veins may range from 1 to $15 \mathrm{~cm}$ in thickness, and may be followed along their length for a few metres. Compositionally, leucosomes are very similar to the paleosome (point count results, Appendix 1). Both are granitic, containing abundant grid- twinned ricrocline and quartz, with lesser, variable ( 8 to $18 \%$ ) amounts of plagioclase. Texturally, mobilizate IIa and granite IIa are also very similar, so much so that, disregarding the small quantities (<12\%) of mafics in the paleosome, the components are indistinguishable (Table 7b). No melanosome selvages have been recognized bordering mobilizate Ila veins in granite IIa, charnockitic gneiss, or granite IIb augengneiss. Nevertheless, on the outcrop, mobilizate IIa segregations may be recognized by their leucocratic nature, and the lack of an internal fabric, as seen in the paleosome. Locally, leucosomes may contain unoriented, well formed metacrysts of the same mafic minerals as seen, occurring in the paleosome (Plate 271a).

Characteristics of mobilizate IIa in streaky granite Ila are outlined in Table 8-4. Plate $27 \mathrm{~b}$ is a photomicrograph illustrating leucocratic mobilizate IIa sampled a few metres from the hornblende metracryst bearing segregation shown as Plate $27 a$.

As in the case of segregations in granite IIa and charnockitic gneiss, mobilizate IIa in granite IIb lacks recognizable melanosome margins. There is no doubt, however, that the granite IIb in which 
these segregations are found is indeed the palecsone source of the leucosodes. Small (ct-scale) leucocratic segregations isclated in flexural hinges of Fab-folds (Plate 28a) within metre-scale outcrops of granite IIb are undeniably isolated in three dimensions, consequentiy they likely segregated in situ. The granite IIb and contained leucosomes share common mineralogy, in varying proportions (Appendix 1): quartz, Eicrocline and plagioclase occur in subequal cuantities. In both components, these minerals average in excess of 1 mo (Table 8-5). Granite IIb retains relict primary granoblastic textures (Table $7 b$ ), showing variable degrees of granulation and recrystallization, wanifested in thin section as nortar texture, in hand sampie as rapakivi-textured augen mosaics. The mobilizate shows no granulation in the thin sections exarined, therefore the texture nay be described as primary granoblastic (Table 7b). In one outcrop, the mobilizate occurs as concordant elongated pods up to $20 \mathrm{~cm}$ wide, 1.5 = long (Fig. 26). These pods contain ragged serpentinized amphibole metacrysts up to $3 \mathrm{ct}$ in diameter (Plate 28b). Amphiboles in the paleosome occur as streaky aggregates partly mantling feldspathic augen; these are similarly altered, however, elsewhere in the outcrop fresh hornblendes are seen. Plate 29 illustrates the typical thin-section aspect of the motilizate Ila material in the outcrop. Although the material examined does not demonstrate mortar texture, granulation in leucosomes may be expected where deformation IIc or III shear is prevalent. 
PLATE 27 .

a. Mobilizate IIa in pranite IIa. Two morpholoeies are seen:

i) coarse gráined pod of mobilizate with 15 mm black amphibole metacrysts.

2) discordant molilizate vein, also contains amphiboles (5 mr). The streaky granite has hornblende as the nain mafic mineral in this outcrop. Location: OS-20.

t. Photomicrograph of mobilizate IIa segretated from granite IIa paleosome. Seme outcrop as Plate $27 a$. Note the franitic composition of the levcosome: abundant microcline is erid-twinned; ouartz is white to even grey. One plagioclase Erain was observed in the field of view represented by this
photograph. Thin section os-20-1. Bar: 2 m. X-nicols.

PLATE 20. Nooilizate II in granite IIb.

a. Leucosome segrefations accumulating in F20 flexural hinges. Location: OS-11.

b. lobilizate II with $1 \mathrm{~cm}$ mafic clots, consistine of serpentinized amphibole. Note fanning of the S2a foliation about the segreqation, indicating a dilative structural trap into which tne wobilizate accuilulated. Location: OS-25.

\section{PLATE 29.}

Kagred serpentinized hornolende mesacrysts in granitic mobilizate IIt in granite IIb. Similar material is photoeraphed fror: the same outcrop in Plate 200 and sketched as Fig. 20 . At photo centre, note fine cuartz-amphibole myrmekitic intergrowth. potasn felospar is erey, cuertz is white. Thir section os-25-Fla. Plane polarizeo licht. Ear: $5 \mathrm{~mm}$. 
PLATE $27 a$.
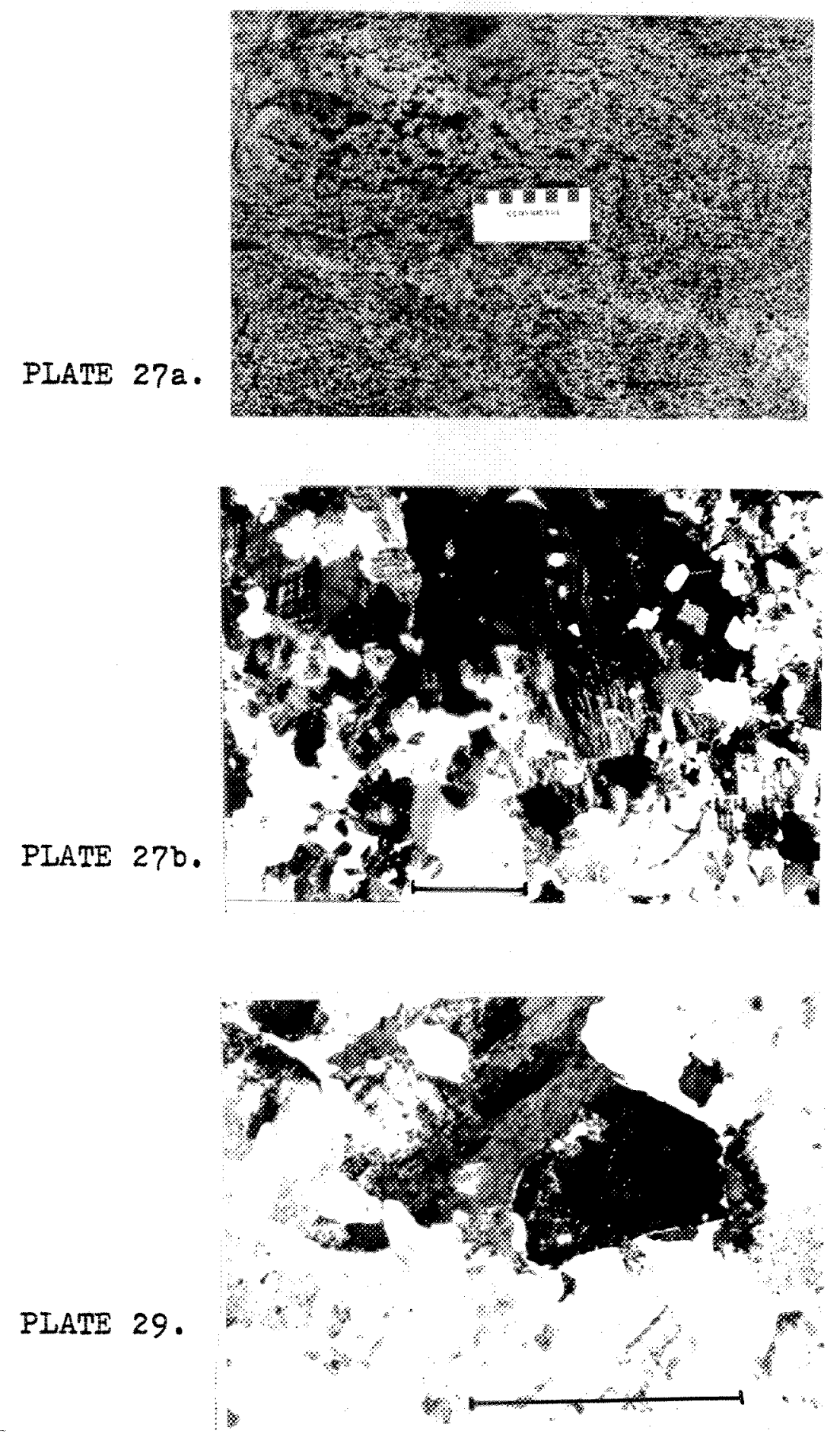


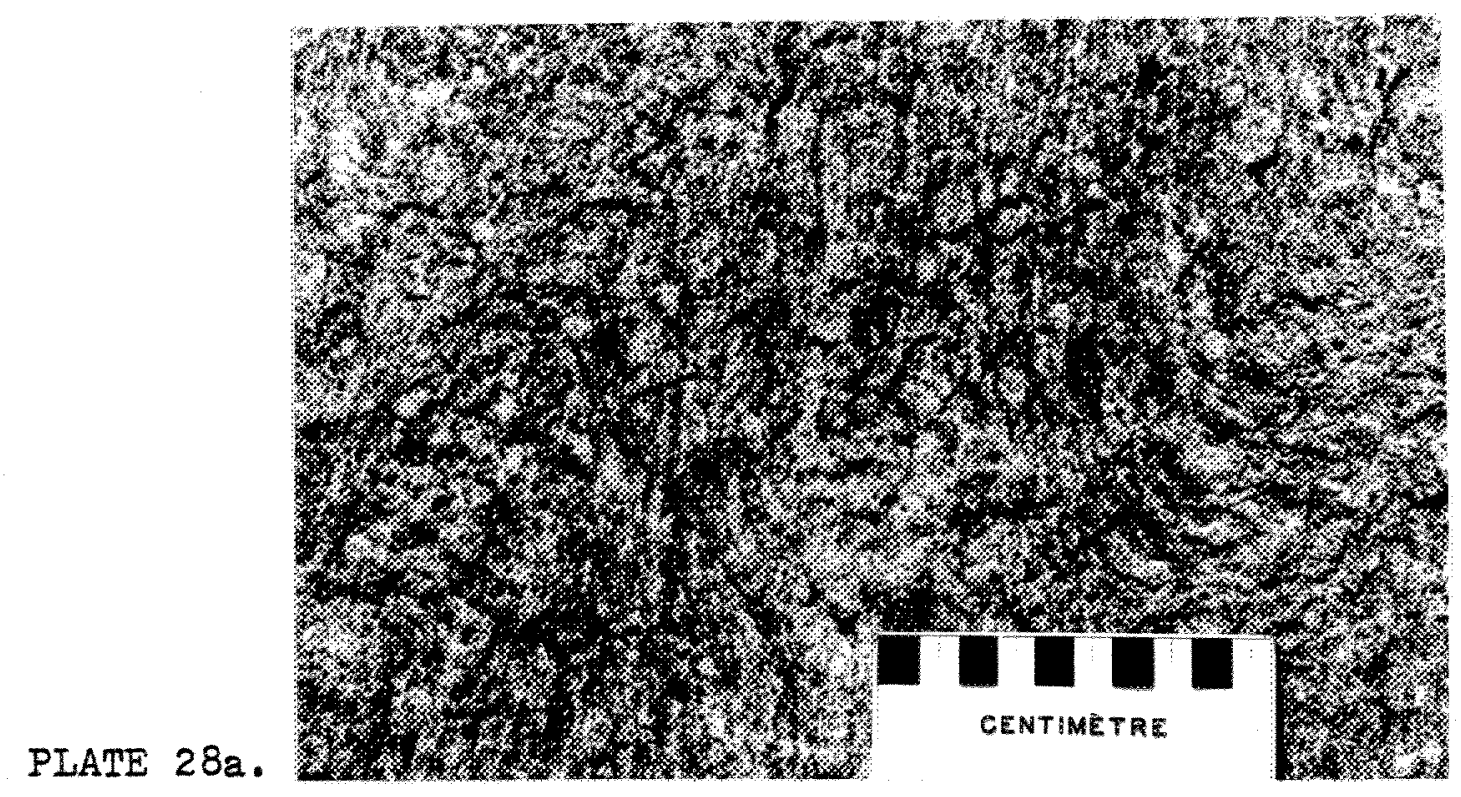

PIATE 28b.

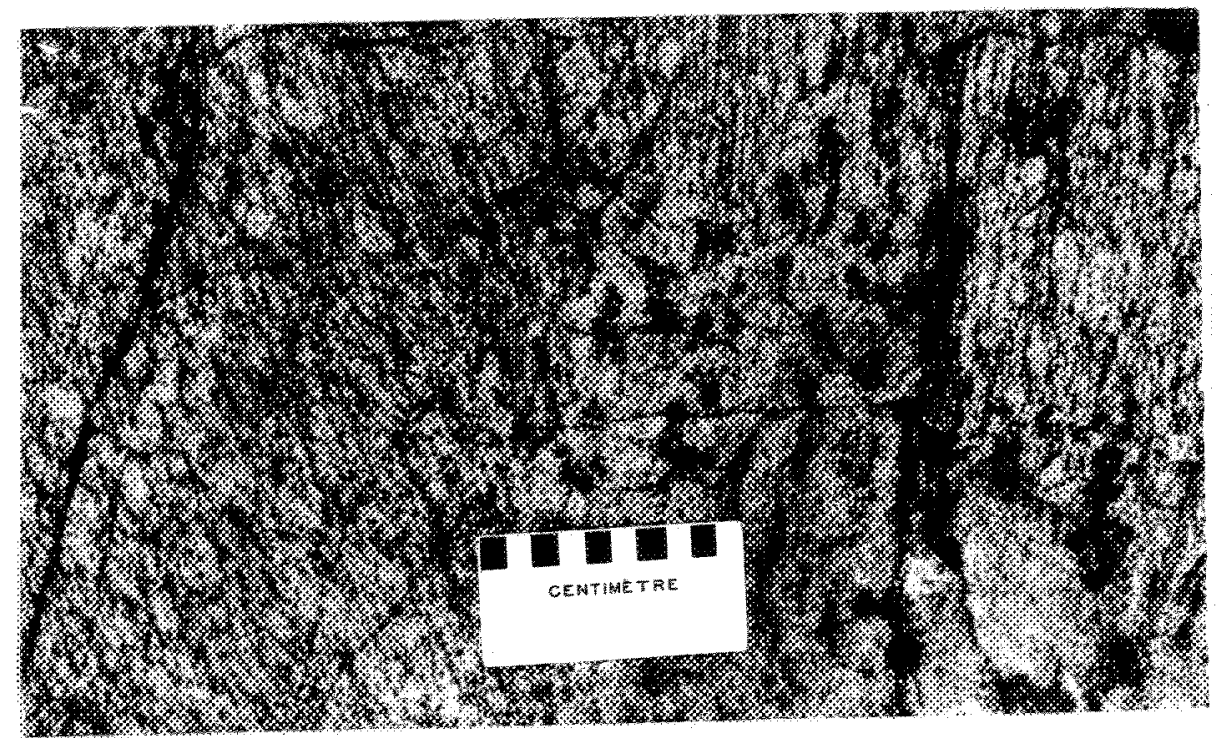


TABLE 8-1: Mineralogical characteristics of mobilizate Ila-paleosome.

GRANITE I (thin sections ON-1-1, OS-1-2b(i,IIO, ON-2-6, ON-1-2)

(note: $0 S-1-2 b(i, i i)$ is mobilizate IIc, petrographically/compositionally similar to mobilizate IIa, in granite' I)

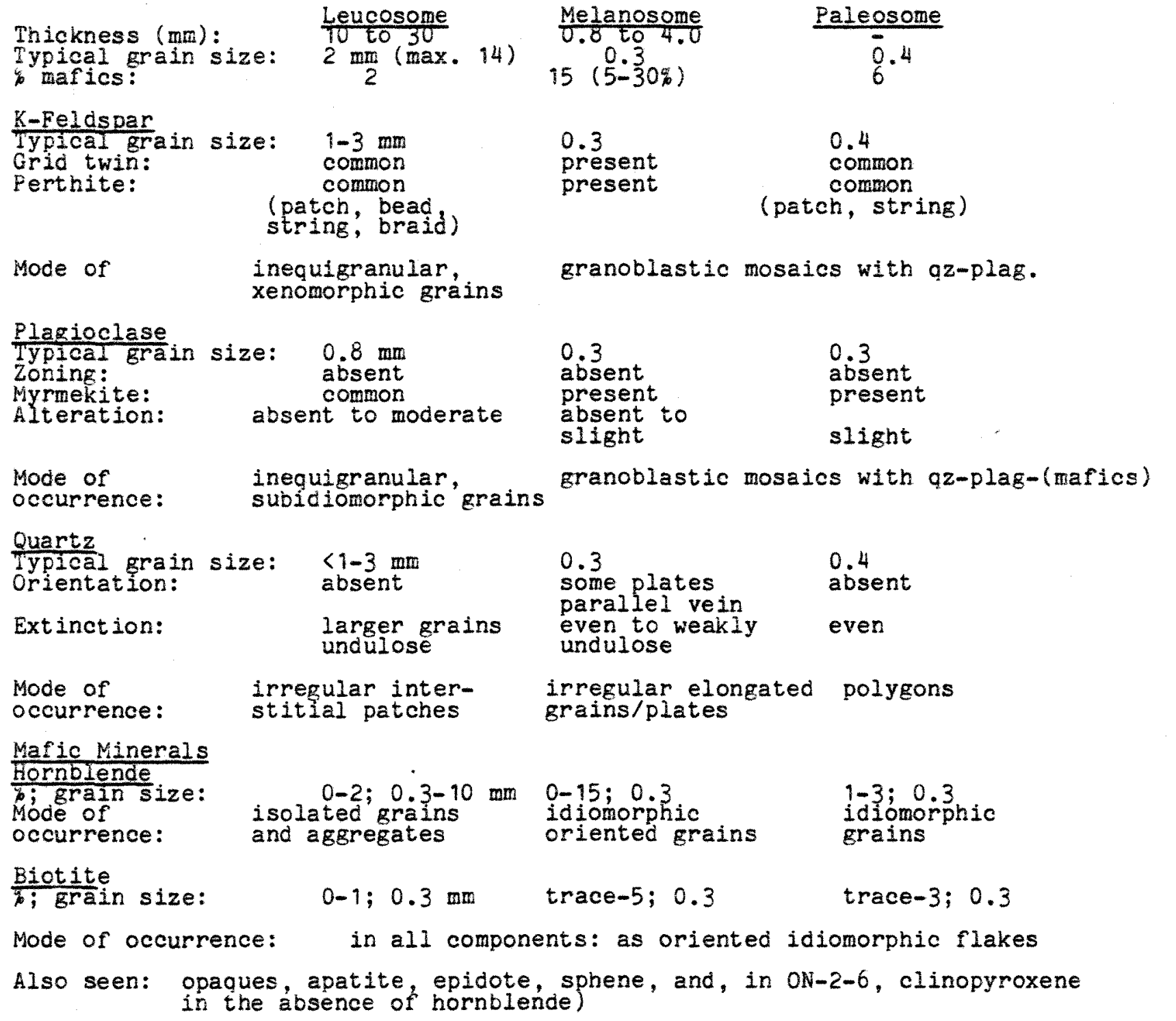


TABLE 8-3: Mineralogical characteristics of mobilizate II-paleosome. CONCORDANT AMPHIBOLITE (thin sections ON-5-2, ON-7-F1C, OS-7-1)

Note: Melanosomes have not been identified for any generation of mobilizate in concordant amphibolite.

\begin{tabular}{|c|c|}
\hline $\begin{array}{l}\text { Thickness (mm): } \\
\text { Typical grain size: } \\
\text { mafics: }\end{array}$ & $\begin{array}{ll}\frac{\text { Leucosome }}{5025} & \frac{\text { Paleosome }}{5.5 \text { to } 3 \mathrm{~mm}} \\
1.5 \text { to } 20^{3}(\mathrm{ON}-7-\mathrm{Fic}) & 0.4 \text { to } 0.8 \\
25 \text { to } 45^{8}\end{array}$ \\
\hline $\begin{array}{l}\text { Plagioclase } \\
\text { Typicatgrain size: } \\
\text { Zoning: } \\
\text { Alteration: } \\
\text { Myrmekite: }\end{array}$ & $\begin{array}{l}0.4 \\
\text { none } \\
\text { absent } \\
\text { absent }\end{array}$ \\
\hline $\begin{array}{l}\text { Mode of } \\
\text { occurrence: }\end{array}$ & subidiomorphic grains, forming mosaics with $q z$ \\
\hline $\begin{array}{l}\text { Quartz } \\
\text { Iypical grain size: } \\
\text { Orientation: }\end{array}$ & $\begin{array}{l}2 \mathrm{~mm} \\
\text { Parallels host } 0.3(0-15 \%) \\
\text { schistosity only in none } \\
\text { vein morphology }\end{array}$ \\
\hline Extinction: & even to weakly undulose \\
\hline $\begin{array}{l}\text { Mode of } \\
\text { occurrence: }\end{array}$ & $\begin{array}{l}\text { lobate grains, polygons interstitial to } \\
\text { interstitial to plag/mafics } \\
\text { plag. as inclusions } \\
\text { in cpx/hbl (ON-7-Fic) }\end{array}$ \\
\hline
\end{tabular}

K-Feldspar: absent in all components of concordant amphibolite

Mafic ano tocessory Minerals

Hornblende

igrainsize:

Mode of

occurrence:
$0-5 ; 0.5 \mathrm{~mm}$
$10-40 ; 0.4$
a) subidiomorphic
subioiomorphic grains
b) replacing poikilitic opx (ON-7-Fic)

Biotite

Mode of

0-1; $0.2 \mathrm{~mm}$
idiomorphic flakes, $\begin{aligned} & 1-40 ; 0.1-0.8 \\ & \text { idiomorphic flakes } \\ & \text { oriented to weakly }\end{aligned}$

Clinopyroxene:

Bi grain size:

Mode of

occurrence:

$0-10 ; 10 \mathrm{~mm}$ (max) not seen megacrysts; margins

transformed to hbl $+q z$ 
TABLE 8-4: Mineralogical characteristics of mobilizate II-paleosome.

GRANITE IIa (thin sections OS-20-1, OS-20/21)

Note: Melanosomes have not been identified in rocks of age group II.

Thickness $(\mathrm{cm})$ :

Typical grain size:

mafics:

R-Feldspar

Typical grain size:

Grid twin:

Perthite:

Mode of

occurrence:

Plagioclase

Typical grain size:

Zoning:

Alteration:

Myrmekite:

Mode of

occurrence:

Quartz

Typical grain size;

orientation:

Extinction:

Mode of

occurrence:

$$
\begin{gathered}
\text { Leucosome } \\
\begin{array}{c}
1 \text { to } 20 \\
2-3 \mathrm{~mm} \\
\text { traces }
\end{array}
\end{gathered}
$$

Paleosome

$$
\begin{aligned}
& 1-2^{-} \mathrm{mm} \\
& 2-8
\end{aligned}
$$

$1.5-2.5 \mathrm{~mm}$

common

present

1

common

rare

irregular grains/patches forming mosaics with qz-plag.

\section{$0.8 \mathrm{~mm}$ \\ absent \\ sight \\ common}

subidiomorphic

grains

$2-3 \mathrm{~mm}$

weak, parailels

$v \in$ in and $S 2 a$

even to weakly undulose in both components

0.6

absent

slight common

subidiomorphic grains

1.5

defines schistosity

lobate and irregular lobate to elongated interto elongated inter- stitial grains and patches stitial grains/patches

Mafic and Accessory Minerals

Eiotite

; grain size:

Mode of

occurrence:

Hornblende

; grain size: not seen

Mode of

occurrence:

Garnet (seen only in OS-20/21)

ï grain size: Mode of

occurrence: not seen

not seen
$2-5 ; 0.2-1 \mathrm{~mm}$ isolated flakes and streaky aggregates of flakes; rarely intergrown with quartz

$2-5 ; 0.3$ to $1.5 \mathrm{~mm}$ subidiomprhic grains forming streaky aggregates + biotite

$1 ; 1.5$ to $2 \mathrm{~mm}$ isolated porphyroblasts. In one case, the garnet is mantled by fanning biotite with polygonal quartz (retrograde) 
TABLE 8-5: Characteristics of mobilizate II-paleosome.

GRANITE IIb (thin sections OS-11-4, OS-25-F1a)

Note: Melanosomes have not been identified in rocks of age group II.

\begin{tabular}{|c|c|c|}
\hline $\begin{array}{l}\text { Thickness }(\mathrm{cm}): \\
\text { Typical grain size: } \\
\text { mafics: }\end{array}$ & $\begin{array}{l}\frac{\text { Leucosome }}{10020} \\
1.5-2.5 \\
0 \text { to } 5\end{array}$ & $\frac{\text { Paleosome }}{1 \text { to } 2}$ \\
\hline $\begin{array}{l}\text { K-Feldspar } \\
\text { Typical grain size: } \\
\text { Grid twin: } \\
\text { Perthite: }\end{array}$ & $\begin{array}{l}1.5 \mathrm{~mm} \\
\text { common } \\
\text { not seen }\end{array}$ & $\begin{array}{l}1.2 \\
\text { common } \\
\text { present }\end{array}$ \\
\hline $\begin{array}{l}\text { Mode of } \\
\text { occurrence: }\end{array}$ & $\begin{array}{l}\text { irregular to } \\
\text { subidiomorphic } \\
\text { grains forming } \\
\text { mosaics with qz }\end{array}$ & $\begin{array}{l}\text { xenomorphic grains, forming } \\
\text { mosaics with qz-plag. }\end{array}$ \\
\hline
\end{tabular}

Plagioclase Typical grain size: Zoning:

Alteration:

Myrmekite:

$\begin{array}{ll}1 \mathrm{~mm} & \begin{array}{l}1 \text { to } 2 \\ \text { absent } \\ \text { absent } \\ \text { slight to moderate } \\ \text { in both components } \\ \text { common }\end{array} \text { comon }\end{array}$

Mode of

occurrence:

irregular to subidiomorphic grains, forming mosaics

Quartz

Typical grain size
Orientation: with qz-K-spar.

1.5 to $2 \mathrm{~mm} \quad 1.5$ to 2

Extinction:

no preferred orientation in either component

Mode of

occurrence:

evenly to weakly undulose in both components

lobate to

ameboid masses

granular to ameboid

Mafic Minerals

Biotite

igrain size:

Mode of

occurrence:

$0-\operatorname{tr} ; j 0.4 \mathrm{~mm}$
isolated flakes

$0-10 ; 0.8$

aggregates of flakes

mantling augen structures

Hornblende

\% grain size:

Mode of

$0-5 ; 0.5-30 \mathrm{~mm} \quad 0-8 ; 0.5-1.5 \mathrm{~mm}$

occurrence:

in both components, as chioritized metacrysts

Note: also trace amounts of apatitie, muscovite, opaques 
v-Mobilizate IIa in Dyke "Amphibolites"

The presence of mobilizate IIa leucosomes in dyke rocks is of special significance, insofar as some leucosomes are evidently autochthonous, while others demonstrably have been introduced from the dyke's host rock (Plate 17e). Since dyke "amphibolites" of age Eroup II incorporate a variety of lithologies, a similar range of autochthonous leucosomes is to be expected. Indeed, dyke leucosomes which, morphologically, appear to be isolated in three dimensions, typically are mineralogically related to the dyke. For example, uncorrelated evenly fine grained granitic dykes of age group II (Table I) frequently contain pink granitic leucosome streaks and veins (Fig. 21). Similarly, dioritic IIc dykes contain trondhjemitic coarse grained leucosomes (Plate 11f, Table 9-1), even though, in this case, the dyke's host rock is granite I (Fig. 18) which generates granitic mobilizates exclusively. Therefore, the granite I host to the dyke cannot be the paleosome source of this levcosome-we must consider the dioritic dyke to be the paleosome. A wider range of possibilities is presented by true "amphibolite" dykes, namely, dyke amphibolites IIa,b. Here, both autochthonous and allochthonous leucosomes are commonly represented, even within the same individual dyke. Injected mobilizates are easily recognized where the host rock is granitic. In this case, pink microcline-quartz rich veins (Table 9-2) which criss cross the dyke (Plate 17e) may be traced to their source in the dyke's host rock (Eig. 31). These eranitic leucosomes commonly recrystallize the dyke amphibolite (Table 9-3) and may contain hornblende clots (Plates 14, 20a,b). The problematical leucosomes, however, are trondhjeritic in composition (plagioclase composition not implied), mineralogically similar, therefore, to mobilizates $I$ and II in concordant amphibolite. However, a wide range of quartz-plagioclase-(microcline) assemblages may be represented within the same dyke, and even within the same hand sample (Table 9-4). It is noteworthy that, in this case, individual leucosomes occur as pinched lenses, which, although presently appearing to be isolated in 
three dimensions, probably formed vein networks prior to deformation. As such, microcline-bearing quartz rich leucosomes (Table 9-4) may be considered to have been introduced from a source outside of both the amphibolite dyke and the granite I host. The remaining trondhjemitic leucosomes which, within individual dykes or in different dykes of similar composition, show similer quartz:plagioclase contents, probably formed by a process or processes responsible for autochthonous trondhjemitic mobilizates in concordant amphibolite.

One such example is of particular interest. In this case, a clinopyroxene-bearing trondhjemitic leucosome is concordant within an even-grained amphibolite IIb dyke, in charnockitic gneiss host rock. Since the chamockitic gneiss always generates granitic leucosomes, the amphibolite may be safely described as the paleosome. The leucosome-paleosome material may be subdivided into four components (see also Table $9-5$ ):

a) central, coarse grained clinopyroxene-bearing trondhjemitic mobilizate II (Plate 30a)

b) marginal, fine grained clinopyroxene - plagioclase - quartz (biotite) zone, largely devoid of hornblende

c) clinopyroxene-bearing amphibolite

d) amphibolite, devoid of clinopyroxene (paleosome)

Features and thicknesses of these zones are described in Table 9-5. Although no melanosome material has been observed in any autochthonous dyke leucosomes, in this one example, zone b) may safely be considered to have been, in large part, the zone in which a), the leucosome, was generated, and from which the leucosome migrated. This is demonstrated by textural evidence (Plate 30b) indicating the breakdown of homblende, yielding clinopyroxene. 
PLATE 30.

a. At left, coarse grained trondhjemitic (plagioclase composition not implied) mobilizate II with clinopyroxene (frey, irregular cleavage): zone "a". At middle, fine grained clinopyroxene-placioclase-quartz-(biotite, hornblende): zone "b" (c.f Plate 30b). At pight, clinopyroxene bearine dyke for a distance of some $3 \mathrm{~cm}$, gradualy dirinishing. The dyke amphibolite paleosome conteins no clinopyroxene. Thin section 0S-21-3 (i). Plane polarized light. Bar: $5^{\circ} \mathrm{mm}$.

b. From zone "b", constituting the melanosome (restite) bordering cinopyroxene bearing trondnjemitic leucosome in dyke amphibolite IIb. Textural evidence for the reaction hornblende (h) ---->clinopyroxene (c). Thin section os-2i-3 (i). Plane polarized lient. Bar: $1 \mathrm{~min}$. 
PIATE $30 \mathrm{a}$.

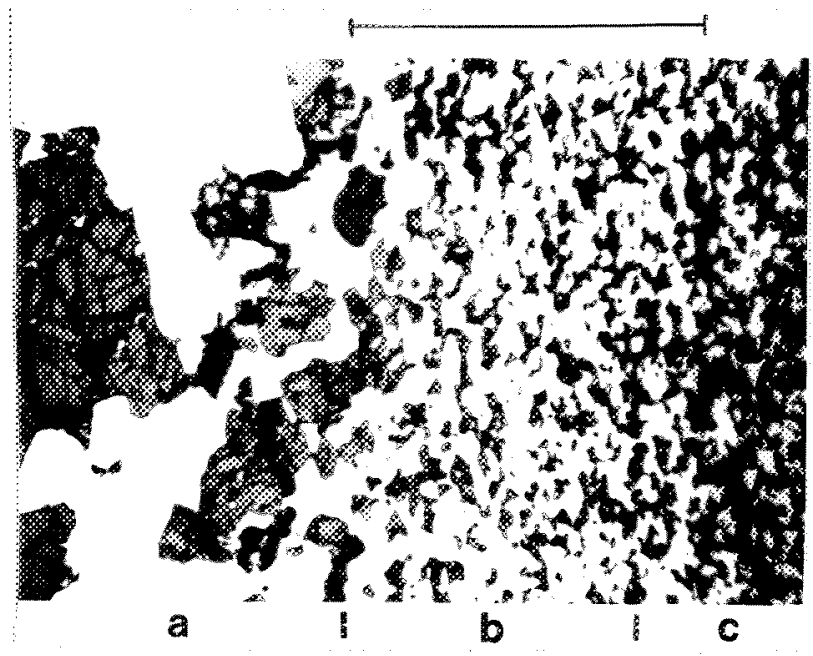

PLATE 30b.

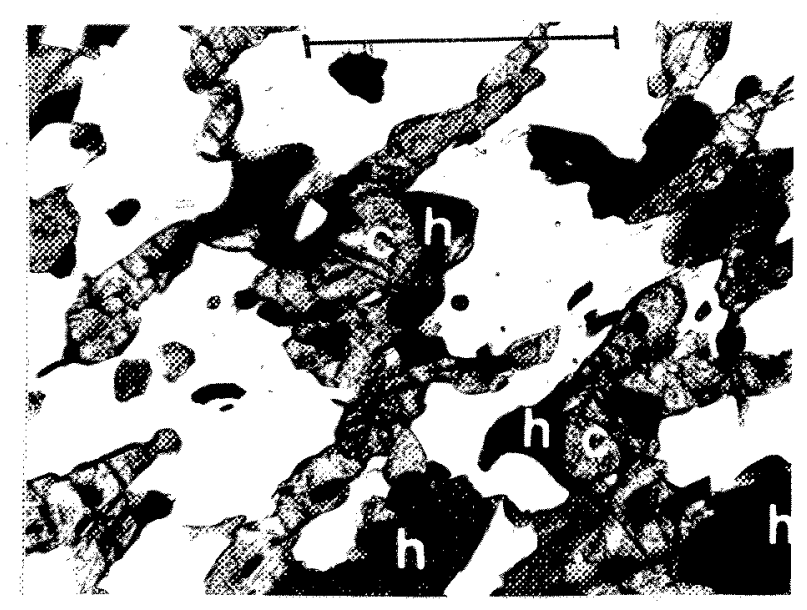


Allochthonous mobilizate II leucosomes are not restricted to intersecting amphibolite II dykes. At two localities (ON-3, OS-13) granite I contacting garnet-sillimanite bearing biotite paragneiss has been brecciated, and infiltrated by garnetiferous mobilizate II generated in the paragneiss. Figure 31 shows a boudinaged and brecciated granite I sill in paragneiss. The interboudin dilation zone hosts pegmatitic allochthonous mobilizate III material, while garnetiferous mobilizate II infiltrates breccia fragment interstices. Small amounts of garnet occur in diffuse mobilizate patches in the marginal zones of some granite I fragments (Fig. 31, inset). The allochthonous mobilizate II (paleosome: paragneiss) contains garnet as the sole mafic mineral, while the granite I contains biotite. A comparison of mineralogical characteristics of the migrant mobilizate II, granite I host, and paragneiss paleosome is presented in Table $9-6$.

3-Mobilizate IIb

With the exception of dyke amphibolites, mobilizate If leucosomes are locally seen following S2C slip cleavage surfaces in all rocks of age groups I and II. These surfaces and leucosomes are particularly well developed in granite I (Figs. 3, 7, 28, 33), but similar structures are also seen locally in concordant amphibolite (Plate 31, and granite IIb (Fig. 33). Since mobilizate IIb leucosomes, by definition, accumulate along planar slip surfaces, this material occurs only as veins, usually paraliel to subparallel to one another within the same outcrop. Mobilizate IIb veins tend to be closely (10 to $50 \mathrm{~cm})$ spaced, and usually are 1 to $5 \mathrm{~cm}$ thick, although more diffuse mobilizate-bearing slip zones up to $1.5 \mathrm{~m}$ wide are not uncommon. In the former case, veins are discontinuous along their length; individual veins about 10 to $30 \mathrm{~cm}$ long abruptly terminate where s2c-slip was insufficiently developed to permit leucosome localization (Fig.3). Along the same surface, the vein material may reappear where shearing is more fully developed (Fig. 3). Internal $\mathrm{S} 2 \mathrm{c}$ is manifested as parallel quartz plates (Plate 33a). 
FIGURE 31.

Migrant mobilizate II generated in granite I crisscrossing effect"). Schistosity measurement indicates the leucocratic granite i biotite foliation (S2a) which, like the dykes, is folded by $F 2 b$ which has no axial plane schistosity.

FIGURE 32.

Pegmatitic mobilizate III filling dilation zone between large boudins of brecciated granite I within the paragneiss secuence at St. Fulgence. The granite has been infiltrated by allochthonous garnetiferous mobilizate II, Renerated in the paragneiss host of the granite I sill. The mobilizate II recrystallizes the Eranitic material, especially the leucocratic mobilizate II; biotite colts advance up to $25 \mathrm{~cm}$ along veins of the latter. Some of the motilizate II veins in the paragneiss have also been granitized by the permatite: these veins are exceptionally quartz-rich and contain potash feldspar mezacrysts up to $5 \mathrm{~cm}$ across. Inset shows the distribution of farnetiferous mobilizate II and granite I breccia fragments. In the map, note the presence of partly recrystalized breccia fragments in the mobilizate III. 


$$
\frac{11}{2}
$$




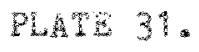

Mobilizate IXb veins followng closely spaced and parallel slip surpaces in concordant andibolite. These veins truncate and of feet a series of subparallel toblizate Ila veins. Mere, mobilizate IIb veins trend N55E: Location: Cx-5.

FTCUA 33.

Mobiligate IIb following slip cleayge surfaces (S20) in grantes IIt and I. Wote in both cases that the robllizates have thin offshoots concordant to $\$ 2 a$ foliation in the paleosome, thereby paralleling wobilizate Ila veing (not shown in figure) This leads to the isolation of patches of paleosome (eg. grantte I), bounded on two sldes by parallel S2e surfaces, and on the remalning two sides by curved (r2b-80lded) s2a foliation. c.r. Plate 320.

\section{PLAT 32. Aspects of mobjidzate Mo in granite I.}

a. Thin wobilizate IDb veins, trending N20E, in $8 p^{n}$ ante $I$. Note at botsom of photo sze-concordant wobllizate Ilb (texturally identical to the man vein leucosome) intruding the paleosome. At top of photo, coarser grained mobilizate IIb raterial ocours as a difruse patch subconcordant to the paleosone schistosity, and contains hornolende clots, absent in the vein. Location: OS-4.

b. Mobilizate IIb following Sec surfaces, in granite I. Note the

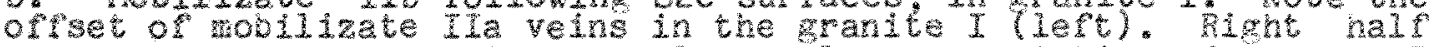
of photo shows extensive hornblende clot overprinting of granite I and contained mobilizate Ila. Hormblende clots consistentiy parallel S2e surfaces, indicating that clot recrystalitiation is concomftant with deformation IIo. The overprint zone extends 2 to 3m into the paleosome. Location: OS-3.

c. Rornblende clot bearing robilizate In ocourring as a thick (50

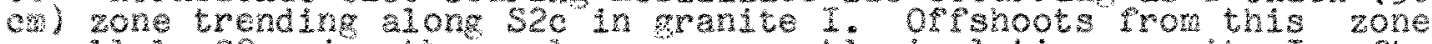
paralle $S 2 a$ in the paleosone partiy solating grante I rafts (above hamer). Note the wafle clot overprinting of the paleosome (right). Looation: 05-3.

d. Sample OS-3-5. Mobilizate ITb whth 8 m horrolende clots. The host tranite $I$ paleosome ls not overprinted by example. Note that the leucosome faces out toward left of photo, as the degree of strain sip diminishes. At right, the mobilizate "IIb diffusely infitrates and recrystallizes the paleosome and mobllizate Ira veins, following S2a. Note melanosomes bordering the moblizate Ila veins in the paleosome at photo centre. Even though S20 is reakly developed in this example, a considerable volume of moolizate has accumelated. 

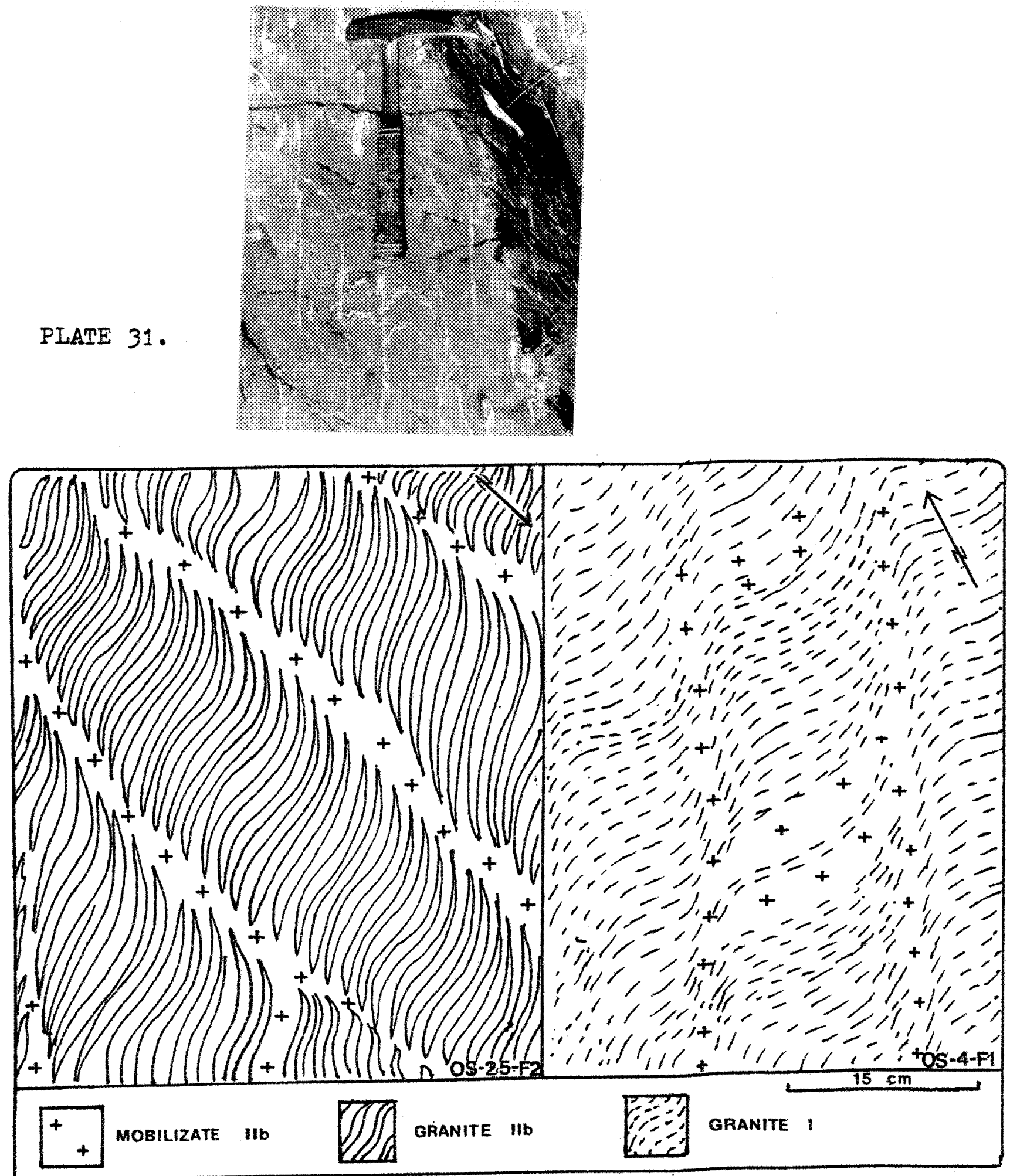

FIGURE 33. 


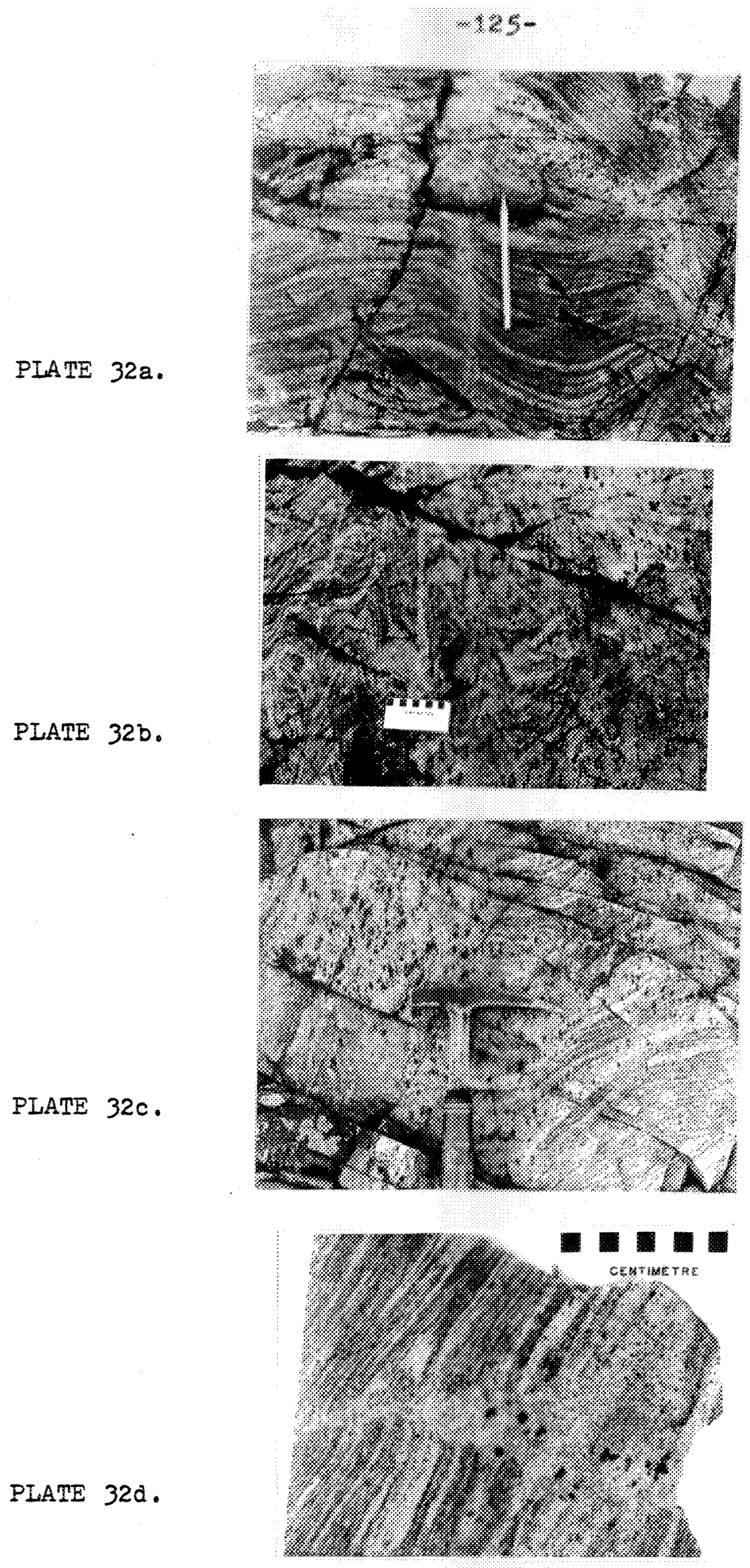


Regardless of the host paleosome, mobilizate IIb veins are never bordered by melanosomes. Thin, isolated veins usually contain no mafic minerals whatsoever (Plate 31, 32a). However, thicker veins, often closely spaced, forming semi-continuous mobilizate rich zones, contain elongated mafic clots which parailel S2c (Plate 32b). These mafic clots consist of the same mafic minerais as occur within the paleosome, for example, hornblende clots occur in hornblende-bearing granite I (Plates $32 b, c$ ). These mafic clots may overprint the paleosome and mobilizate I and IIa veins (Plates $32 b, c$ ). Mobilizate IIb veins commonly trend away from the parallel series of $\mathrm{s} 2 \mathrm{c}$ surfaces, forming $1 \mathrm{~cm}$ thick of fshoots paralleling s2a (and mobilizate IIa) in the paleosome. Several of these offshoots may occur, joining closely spaced $\mathrm{S} 2 \mathrm{c}$ surfaces, thereby isolating patches of the paleosome (Fig. 33, Plate 320). Although mafic clots often overprint the adjacent paleosome (Plate 33b), mobilizate IIa segregations may also contain $1 \mathrm{~cm}$ amphiboles, similar mafic clots not being seen in the adjacent gneiss (Plate 32d).

Table 10 summarizes the petrography of mobilizate IIb and its adjacent mafic overprint zone, in granite $I$. The compositional similarity of these zones is reflected in modal analysis data, summarized in Appendix 1.

4-Mobilizate IIc

Coarse-grained discordant pods of leucosomes with S2a-concordant offshoots bounded by well defined melansomes are seen locally in granite $I$. Since these pegmatoids cross-cut mobilizate IIb, schistosity $\mathrm{S} 2 \mathrm{c}$, and all earlier mobilizates and schistosities, these leucosomes are termed mobilizates IIc. They have only been identified in granite I paleosomes, particularly at outcrops OS-1 to OS-4. These 
granitic leucosomes were initially identified as mobilizate III pegmatites, owing to their coarse (to $3 \mathrm{~cm}$ ) grain size and large volumes, relative to thin, albeit well defined, melanosomes. However, the presence of mareinal melanosomes, and apparent isolation in three dimensions (Fig. 28) indicate that these pegmatoids are in situ. Furthermore, as discussed in section IVB-2, melanosome-ieucosome plagioclase compositions indicate an anatectic origin for these leucosomes. As a result of the petrographic similarity of mobilizate IIc to mobilizate IIa, and its unique (?) occurrence in granite I paleosomes, the petrography of mobilizate IIC is described in section IVB-2.

In addition to the segregation of leucocratic veins, migmatization II locally initiated feldspar blastesis in amphibolite dykes in granite IIb (Plate 34). Since microcline porphyroblasts in both granite IIb and the dyke are mantled by plagioclase (rapakivi texture), it is clear that the augen-texture typifying granite IIb in part developed during migmatization II. 
PLATE 33.

a. Internal S2C shearing in mobilizate IIb in granite I is manifested as parallel quartz plates $(a)$. Thin section os-3-block (i). Bar: 1 me. X X-nicols.

b. Ragged, poikilitic horrblende aggreate from mafic overprint zone borderine a mobilizate IIb vein, in hornblende-bearine granite $I$. Note the similarity of these amphibole clots with those occurring in recrystallized granite I adjacent to granitic mobilizate II (Plate 38b). Thin section OS-3-2. Bar: $2 \mathrm{~mm}$. plane polarized iight.

\section{PLATE 34.}

Feldspar blastesis "homogenizing" an amphibolite dyke in granite IIb. Both the microcline porphyroblasts in the dyke and the augen structures in the granite locally show rapikivi texture. Location: ORM-1. Scale: feldspars in the dyke are 1 to $2 \mathrm{~cm}$ across. 
PIATE $33 a$.

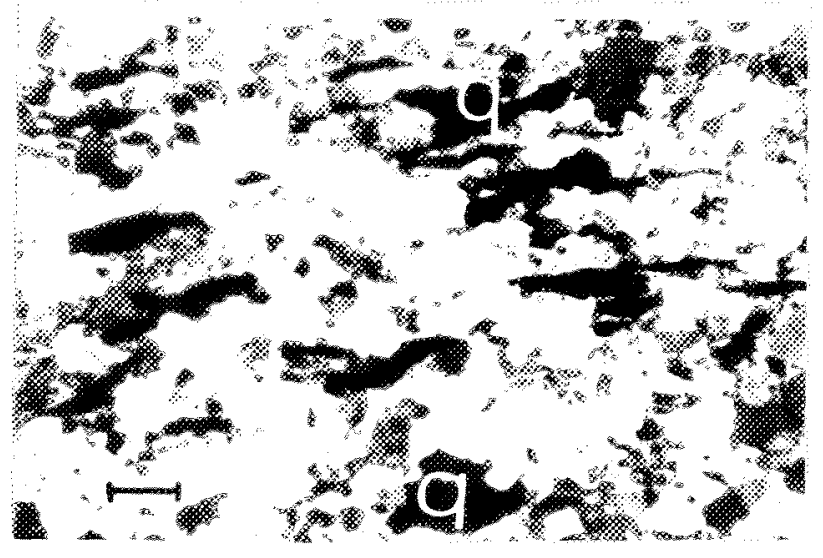

PLATE 33b.
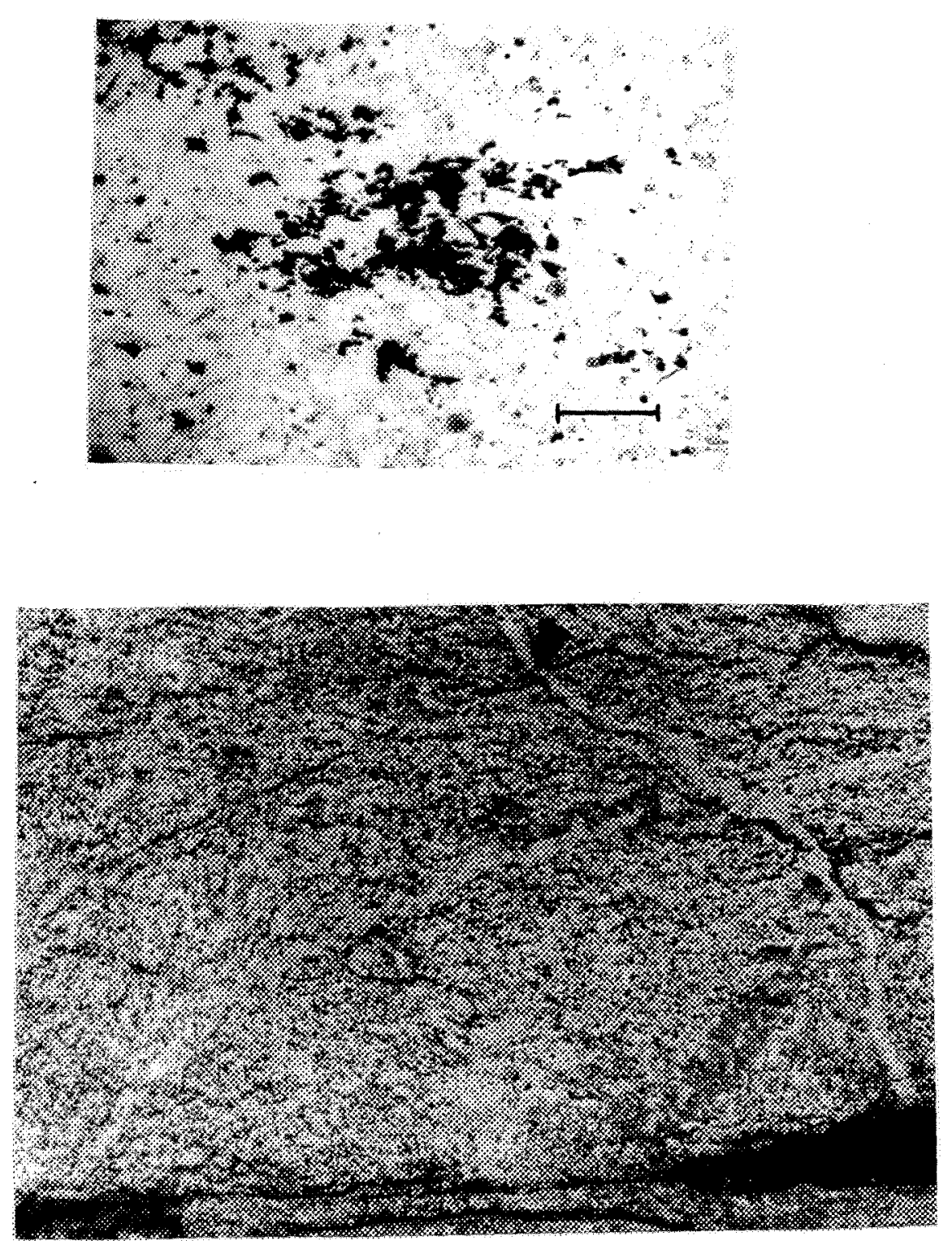

PIATE 34. 
TABLE 9-1: Mineralogical characteristics of mobilizate II in dyke amphibolite II. DYKE AMPHIBOLITE IIC (dioritic) (thin section OS-26-F1a)

Note: This sample is the only leucosome-dyke assemblage containing a marked enrichment of mafics bordering the leucosome. This may, at the outset, considered to be either a melanosome, or simply mareinal recrystalization. Leucosome Melanosome (?) Dyke Host

Thickness $(\mathrm{mm})$ : Typical grain size: to mafics:

Plagioclase Typical grain size: Zoning:

Alteration:

Myrmekite:

Mode of

occurrence :
50

$1.5 \mathrm{~mm}$

trace

$1.5 \mathrm{~mm}$

absent

absent

not seen

hypidiomorphic, inequigranular grains forming mosaics with az
$1-5$
0.5
40

0.4

absent

absent

not seen

$$
\overline{0} .4
$$

0.4 absent absent not seen

irregular to hypidiomorphic grains, roughly equigranular

Quartz

Typical grain size:

Orientation:

Extinction: $1.5-2 \mathrm{~mm}$
parallels veins
undulose

0.3

none

0.3

even

none

elongated, inter- polygonal and lobate grains

Miode of

occurrence: irregular grains

K-Feldspar: minor quantities $(<3 \%)$ seen only in dyke host (paleosome?)

Mafic Minerals

Eiotite

; grain size:

Mode of

occurrence:

trace; 0.5
isolate filakes

absent

Hornblende ; Grain size:

Mode of occurrence:

Clinopyroxene

; grain size: Mode of occurrence:

absent
$40 ; 1$

clusters of flakes, paralleling vein

absent

absent
$1 ; 0$. isolated flakes, sometimes clustered, defining S2a

$3 ; 0.6$

irregular to hypidiomorphic grains
$1 ; 0.5$ irregular grains assoc. iated with hornblende 
TABLE 9-2: Mineralogical characteristics of mobilizate II in dyke amphibolite II. DYKE AMPHIEOLITE IIb (thin section OS-21-3; host rock of dyke is granite IIa). Note: The vein is seen to be an of shoot of mobilizate II from granite IIa (Sederholm effect).

Thickness (mm): Typical grain size: Leucosome 20 $2.5 \mathrm{~mm}$ Dyke Host

Plagioclase

Typical grain.size:
Zoning:
Q iteration:
Myrmekite:
Mode of
occurrence:
Quartz
Typical grain size:
Orientation:
Extinction:
Mode of
occurrence:

\section{K-Feldspar}

Typical grain size:

:

Grid twin:

Perthite:

Mode of

occurrence:

\section{Mafic Minerals}

Clinopyroxene

; Erain size:

Mode of

occurrence:

Biotite

; grain size:

Mode of

occurrence:

\section{$0.5 \mathrm{~mm}$ \\ absent \\ 2 \\ absent present}

small xenomorphic interstitial grains

\section{$2 \mathrm{~mm}$}

none

weakly undulaose

interstitial irregular polygons (minor)

and seriate to lobate

patches; mortared polygons

juxtaposing K-spar.

$3 \mathrm{~mm}$

$-50$

present

common

large interlocking xenomorphic grains with interstitial quartz

$$
\begin{aligned}
& \text { trace; } 0.8 \\
& \text { isolated, interstitial } \\
& \text { (with qz) grains }
\end{aligned}
$$

trace; $0.4 \mathrm{~mm}$ isolated flakes, interstitial, with $\mathrm{cpx}$
0.5

0.5

absent

20

absent

absent

xenomorphic grains

$$
\begin{gathered}
0.2 \\
\text { none } \\
\text { even }
\end{gathered}
$$

$$
\text { polygons (minor) }
$$

$10 ; 0.8$

oriented flakes 
TABLE 9-3: Mineralogical characteristics of mobilizate II in dyke amphibolite II. DYKE AMPHIBOLITE IIb (thin section OS-3-4; host rock is granite I).

Note: This sample is from a dyke intersected and altered by mobilizate IIb. Here, the dyke is $1 \mathrm{~cm}$ thick, and is bounded on three sides by mobilizate The amphibolite is bordered by a continuous, $1 \mathrm{~mm}$ thick alteration zone, marked by an increase in size and of (fresh) hornblende.

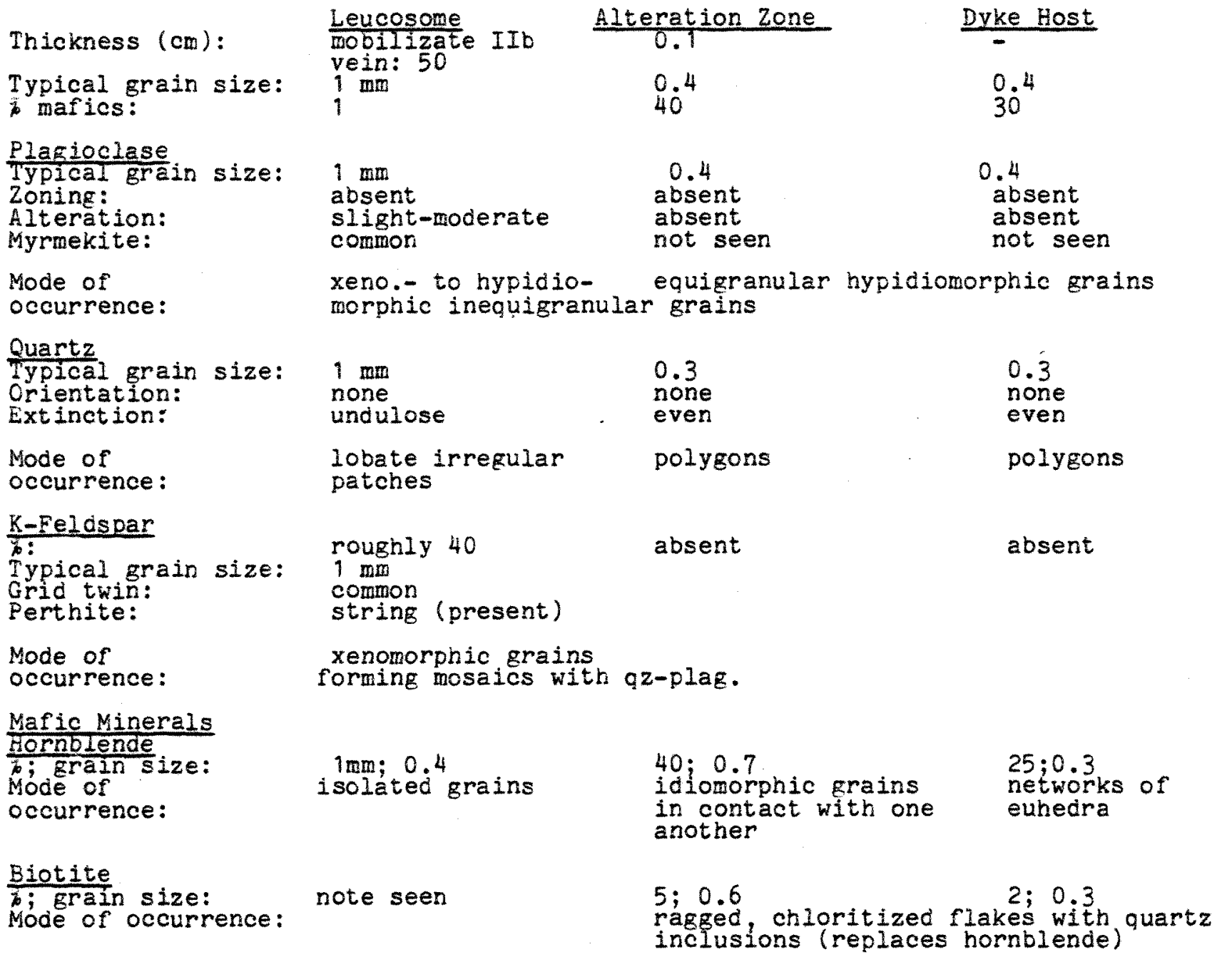


TABLE 9-4: Mineralogical characteristics of mobilizate II in dyke amphibolite II DYKE AMPHIBOLITE IIb (even grained amphibolite; thin sections ON-4-2i,ii. Host rock is granite I)

Note: Amphibolite dykes may contain in situ mobilizate II leucosomes, or may be cross-cut by migrant mobilizates originating from the dyke's host rock. In neither case are definite melanosomes seen. Note that in the case of migrant mobilizates, the dyke may be recrystallized where in contact with the leucosome.

\begin{tabular}{|c|c|c|}
\hline $\begin{array}{l}\text { Thickness }(\mathrm{cm}) \\
\text { Typical grain size: } \\
\text { mafics: }\end{array}$ & $\frac{\text { Leucosome }}{\frac{2}{2} \mathrm{~mm}}$ & $\frac{\text { ke Host }}{4.8}$ \\
\hline $\begin{array}{l}\text { Plazioclase } \\
\text { Fypical grain size: } \\
\text { Zoning: } \\
\text { Alteration: } \\
\text { Myrmekite: }\end{array}$ & $\begin{array}{l}1.5 \mathrm{~mm} \\
\text { absent } \\
\text { absent to slight } \\
\text { not seen }\end{array}$ & $\begin{array}{l}0.6 \\
\text { absent } \\
\text { absent } \\
\text { not seen }\end{array}$ \\
\hline $\begin{array}{l}\text { Mode of } \\
\text { occurrence: }\end{array}$ & $\begin{array}{l}\text { hypidiomorphic } \\
\text { grains }\end{array}$ & $\begin{array}{l}\text { hypidiomorphic } \\
\text { grains }\end{array}$ \\
\hline $\begin{array}{l}\frac{\text { Quartz }}{\text { Typical grain size: }} \\
\text { Orientation: }\end{array}$ & $\begin{array}{l}2 \mathrm{~mm} \\
\text { some grains } \\
\text { oriented parallel } \\
\text { to segregation }\end{array}$ & 0.4 \\
\hline Extinction: & even & even \\
\hline $\begin{array}{l}\text { Mode of } \\
\text { occurrence: }\end{array}$ & $\begin{array}{l}\text { polygonal to } \\
\text { irregularliobate } \\
\text { interstitial grains }\end{array}$ & polygons \\
\hline $\begin{array}{l}\text { K-Feldspar } \\
\text { Typicaigrain size: } \\
\text { Grid twin: } \\
\text { Perthite: }\end{array}$ & $\begin{array}{l}3 \mathrm{~mm} \\
\text { poorly developed } \\
\text { some grains have f.g. } \\
\text { patchy plagioclase }\end{array}$ & absent \\
\hline $\begin{array}{l}\text { Mode of } \\
\text { occurrence }\end{array}$ & mosaics of xenomorphic & grains \\
\hline $\begin{array}{l}\text { Ratio of } \\
\text { plag/K-spar/qz: }\end{array}$ & $\begin{array}{ll}-O N-4-2 i: & (50-90) /(0-5) /(5 \\
-O N-4-2 i i: & 0 / 20 / 80\end{array}$ & $50-10)$ \\
\hline \multicolumn{3}{|c|}{$\begin{array}{l}\text { Note: Thin section ON-4-2i contains two veins; one is a } \\
\text { plagioclase-quartz assemblage, the other consists } \\
\text { almost entirely of plagioclase. Section oN-4-2ij } \\
\text { contains one vein, a quarta-microcline assemblage. } \\
\text { Both thin sections were made from the same hand } \\
\text { sample All leucocratic veins in the sample parallel } \\
\text { the biotite foliation and are lensoid in shape. }\end{array}$} \\
\hline
\end{tabular}


TABLE 9-5: Mineralogical characteristics of mobilizate II in dyke amphibolite II.

DYKE AMPHIBOLITE IID (thin sections OS-21-3i, ii)

$\begin{array}{lcc}\text { Thickness }(\mathrm{cm}): & \frac{\text { Leucosome }}{2} & \frac{\text { Dyke Host }}{0.5} \\ \text { Typical grain size: } & 5 \mathrm{~mm} & 0.5 \\ \text { Tyafics: } & 10 & 25^{5}\end{array}$

Note: the neosome is zoned, as follows:

ZONES: a) central, coarse grained leucosome ( $2 \mathrm{~cm}$ thick)

b) marginal fine grained zone ( $5 \mathrm{~mm}$ thick), depleted in

hornblende, but, like the leucosome, with clinopyroxene

c) dyke host, with hornblende and clinopyroxene. Pyroxenes fade out over a thickness of 2 to $3 \mathrm{~cm}$

c) unaffected hornblende-plagioclase dyke amphibolite

Zone a) is the in situ mobilizate (host gneiss of the dyke is granite IIa) Zones b) and c) are probably melanosome margins, source of the mobilizate Zone d) is the paleosome

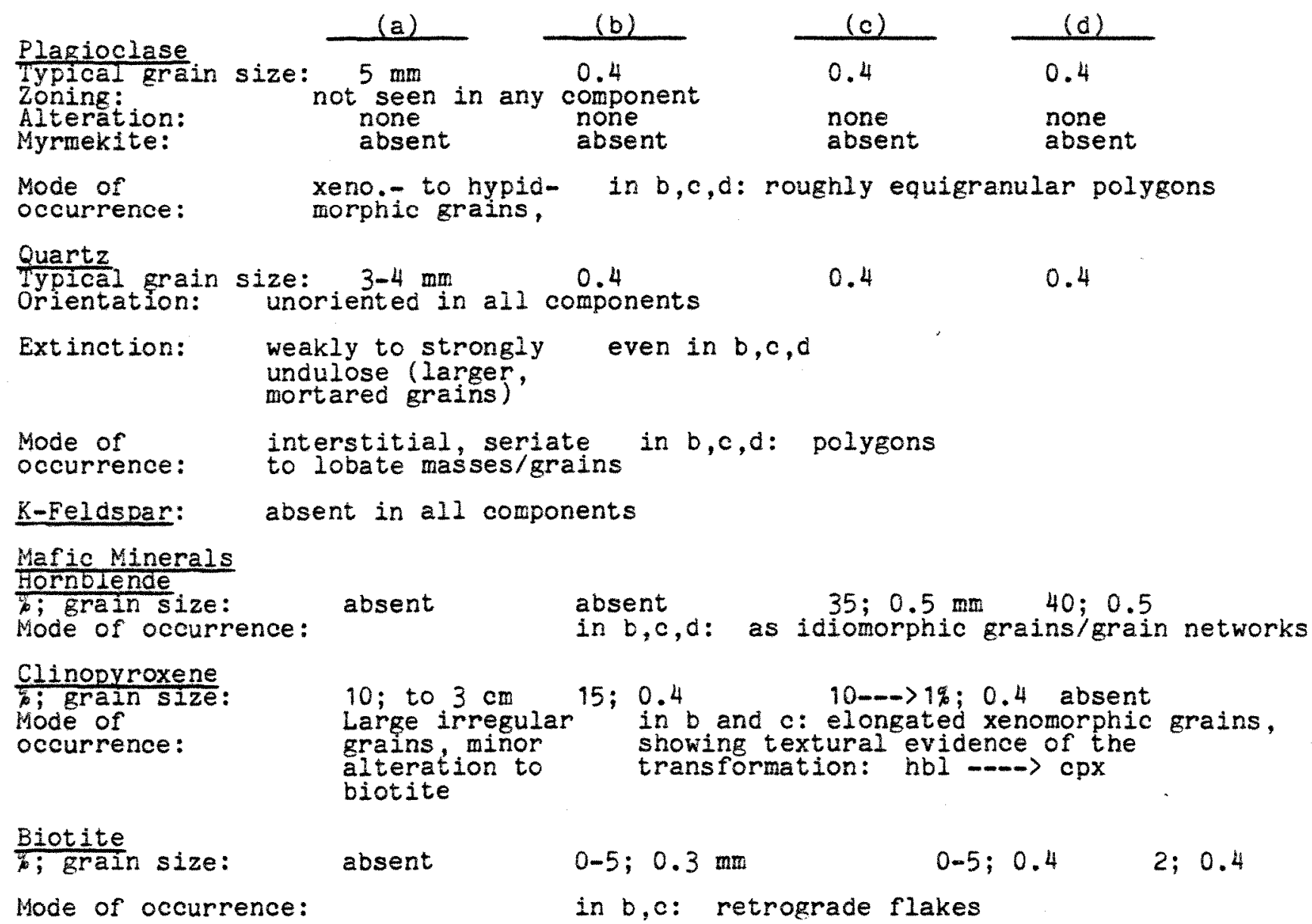


TABLE 9-6. Characteristics of migrant mobilizate II mineralogy.

Note: Migrant mobilizate II is defined as leucosome material which generated during migmatization II

found in a lithology other than its source paleosome.

Host Rock: Granite I; Paleosome: (Source): Paragneiss

(Thin sections oN $-3-$ Fid and OS -13 Block)

Thickness $(\mathrm{cm})$ :

Typical grain size:

* mafics?

K-Feldspar

Typical grain size: $\quad 1 \mathrm{~mm}$

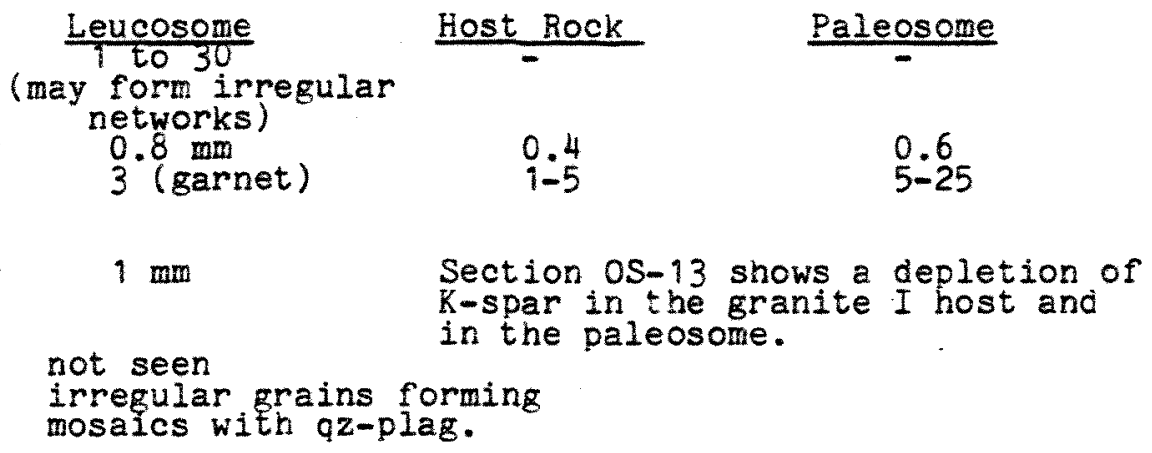

0.6

absent

common

absent

slight

rare

0.5

absent

slight

rare

inequigranular,

irregular grains

equigranular, hypidiomorphic grains
0.4

all components

equigranular rounded grains

present as in leucosome, in diffuse móbilizate patches

with numer

$\mathrm{qz}$ inclusions

Biotite

; grain size: Mode of occurrence: tr.; 0.4

isolated fresh to

chloritized flakes
$1-5: 0.4$

isolated flakes defining S2a
0.4

none

inequigranular

lobate grains

(not seen in either sample

$10 ; 0.5$

isolated to clustere flakes paralleling. S2a 
TABLE 10. Characteristics of mobilizate IIb-paleosome mineralogy. GRANITE I (thin sections, OS-3-Block i, ii, OS-3-2.

Note: mobilizate IIb has no associated melanosome, however, mafic overprinting of the paleosome is not uncommon.

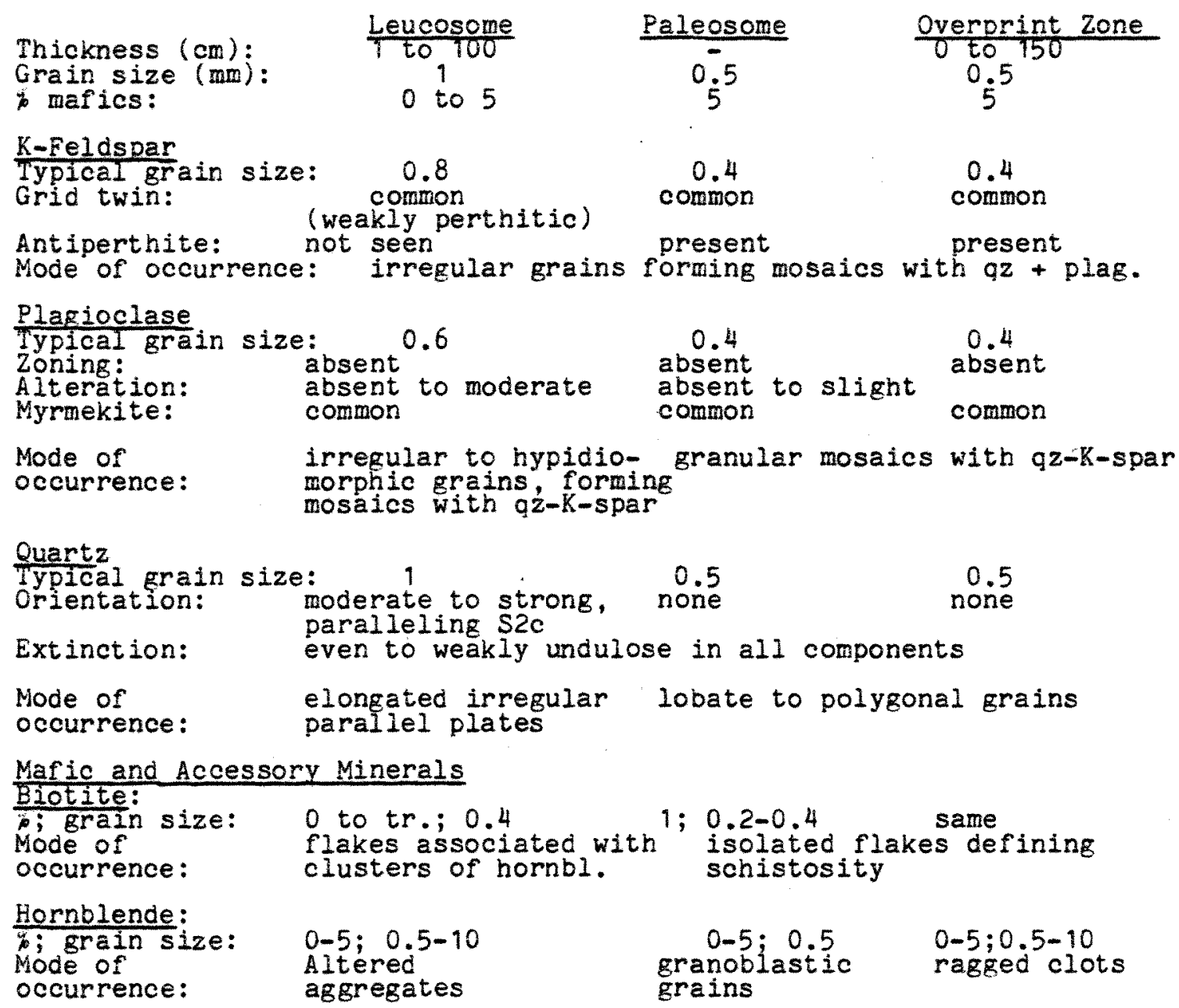


5-Hobilizate III

Mobilizate III occurs as concordant to cross-cutting (Plate 35, Fig. 34) pegmatite veins, from a few centimetres to several metres wide, here and there swelling to thicknesses up to and exceeding $20 \mathrm{~m}$. With the local exception of concordant pegmatites veins, mobilizate III localization is rarely controlled by host rock structural features, tending to fill, instead, fractures. However, mobilizate III pegmatites locally are seen to segregate in interboudin dilation zones (Fig. 31) and may follow S2c shear surfaces (Fig. 27d), thereby paralleling mobilizate IIb veins. Where pegmatite veins are seen to fill fractures, renewed movement along these surfaces develops $\$ 3$ shear schistosity in the crystallized mobilizate (Figs. 9, 26), indicating that the pegmatites were intruded during deformation III. Where filling joint sets, the pegmatites assume a trellis pattern (Plate 36). In addition to their occurrence as discordant veins, the local presence of host rock inclusions (Plate 37 ) demonstrates the intrusive nature of mobilizate III. As such, these pegmatites are clearly allochthonous: melanosome seams are never seen and pegmatites match host rock leucocratic mineralogy only by coincidence. As described in section IIB-3, and outlined in Table 11, mobilizate III ranges from granitic to trondhjemitic in composition, and pegmatitic to granitic in texture. Where, by chance, mobilizate III vein material is compositionally similar to in situ mobilizates seen in their host rocks, the pegmatites may be distinguished by the absence of melanosomes and the tendency of mobilizate III to recrystallize host rocks and inclusions.

Fecrystallization of host rocks and their in situ mobilizates is, with the possible exception of diffuse mafic-clot bearing zones bordering some mobilizate IIb veins (Plates $32 b, c$ ), a feature unique to migrant pegmatoids infiltrating rocks of different lithology than their paleosome source. Host rock alteration is seen within a semi-continuous zone (where present) from 1 to $-30 \mathrm{~cm}$ thick, adjacent 
to the permatite. These zones typically contain metacrysts of the same tafic mineral(s) occurring in the host rock. For example, hornblende porphyroblasts may border pegmatites in horntlende-bearing granite I (Plate 38a), while biotite clots are more likely to be developed in a biotite-bearing granite I (Fig. 32). Recrystallization of this sort is typical of allochthonous leucosomes, consequentiy, similar recrystallization phenomene were described where granitic leucosomes from granitic host rocks infiltrate amphibolite dykes (Plates 20a,b). Of particular significance is the biotitization of concordant amphibolite by both granitic (Fig. 34) and trondhjemitic (Fig. 11, Plate 36) pegmatites. Table 12 summarizes mineralofical changes shown by concorcant amphibolite recrystaliized by trondhjemitic mobilizate III. This example demonstrates that Detasomatism and silicification may occur in addition to recrystelizition of mafic mineral phases already present in the host rock (ex. Plates $38 a, b$ ).

Although mobilizate III usually retains a primary granoblastic texture (Table 7b), locally weak tectonic fabrics are developed, particularly in pegnatites located in 53 shear zones (Figs. 9, 26). Plate 39 a shows well developed elongated quartz patches, paralleling $S 3$ in the thin kranitic peguatite illustrated in Fig. 9. These oriented quartz plates are lobate to plate-like in form, and consist of serrated quartz mosaics, partiy enveloping perthite megacrysts.

Both granitic and trondhjemitic pegmatites, and "granite III", locally contain from 5 to $30 \%$ magnetite. Plate 390 shows a magnetite rich trondhjemitic pegmatite, illustrated in Plate 14 , in which magnetite and finer grained serrate to polygonal plagioclaseouartz-(micocline) mosaics are interstitial to xenomorphic plagioclase megacrysts. 
FIGURE 34.

Discordant offshoot of pegmatitic mobilizate III rich in potash feldspar and quartz, cutting concordant amphibolite II dykes in granite I. Note thin off shoots of the pegmatite from the discordant vein and the sporadic occurrence of mobllizate II material from granite I paleosome, segregating in dilational stretched points in the amphibolite dykes. Plate 35 shows an inclusion of granite I within the same mass of pegmatite, some $8 \mathrm{~m}$ wide.

FIGURE 35.

Recrystallization of amphibolite inclusions in pegmatitic mobilizate III (granitic). A biotite rich rim surrounds a pale, relatively fine grained zone (plagioclase-biotite-quartz-opaques-apatite; medium grained, essentially unaltered amphibolite occurs at the centre. 'Small, inclusions are completely altered to biotite; intermediate sized enclaves lack the unaltered central core. Modal compositions of these zones are presented in Table 12 , for amphibolite recrystallized by trondhjemitic mobilizate III. Part of this figure is photographically reproduced as Fig. 22-11 in Owen and Dimroth (1980).

PLATE 35.

Crosscutting mobilizate III pegmatite, roughly perpendicular to the streaky $52 a$ foliation in the host charnockitic gneiss. To right of hammer head are $7 \mathrm{~cm}$ long beige coloured potash feldspar porphyroblasts, forming a coarse grained concordant layer in the host gneiss. Location: OS-29/30.

\section{PLATE 36.}

Trellis pattern outlined by joint-filling trondhjemitic mobilizate II pegmatite veins, in concordant amphibolite. Despite the tronhjemitic mineralogy of the pegmatite the leucosome is identified as mobilizate II, not mobilizate II, since semi-continuous biotite reaction rims border the leucosome. c.f. Fig. 34 for similar type of reaction. Location: ON-7.

\section{PLATE 37.}

Inclusion of host granite $I$ in mobilizate III pegmatite. This inclusion is oriented paraliel to the host rock foliation. Distance between the inclusion and host rock is about $3 \mathrm{~m}$. The granite. I contains thin, closely spaced amphibolite dykes (c.f. Fig. 6), ragged relicts of which extend for some 1 to $2 \mathrm{~m}$ into the pegmatite. Tne leucocratic granite $I$ is replaced for 10 to $30 \mathrm{~cm}$ along the inclusion"s length by the granitic pegmatite. Same pegmatite mass as illustrated in Figs. 6 and 33 . Location: OS-30. 


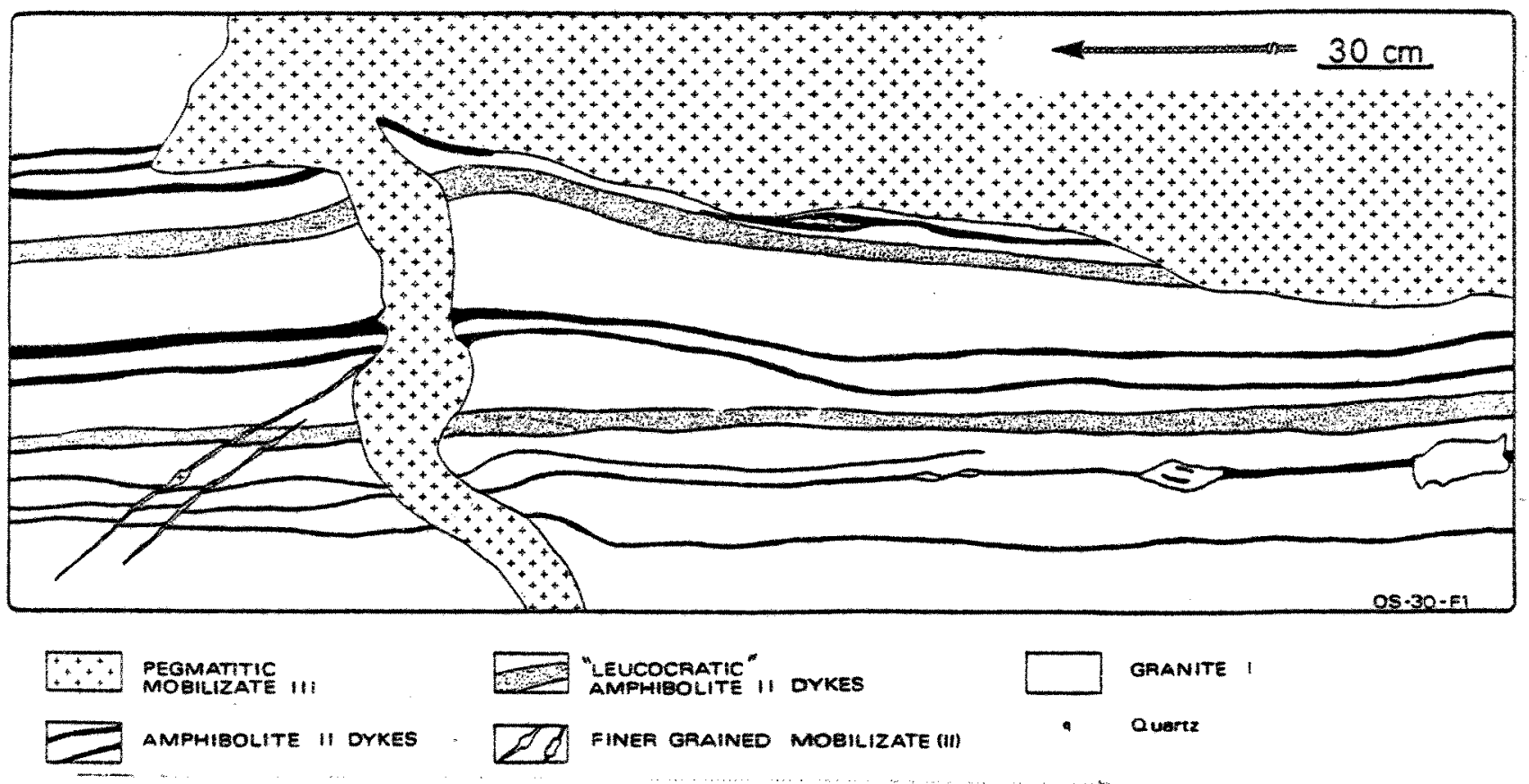

FIGURE 34.

PIATE 35.

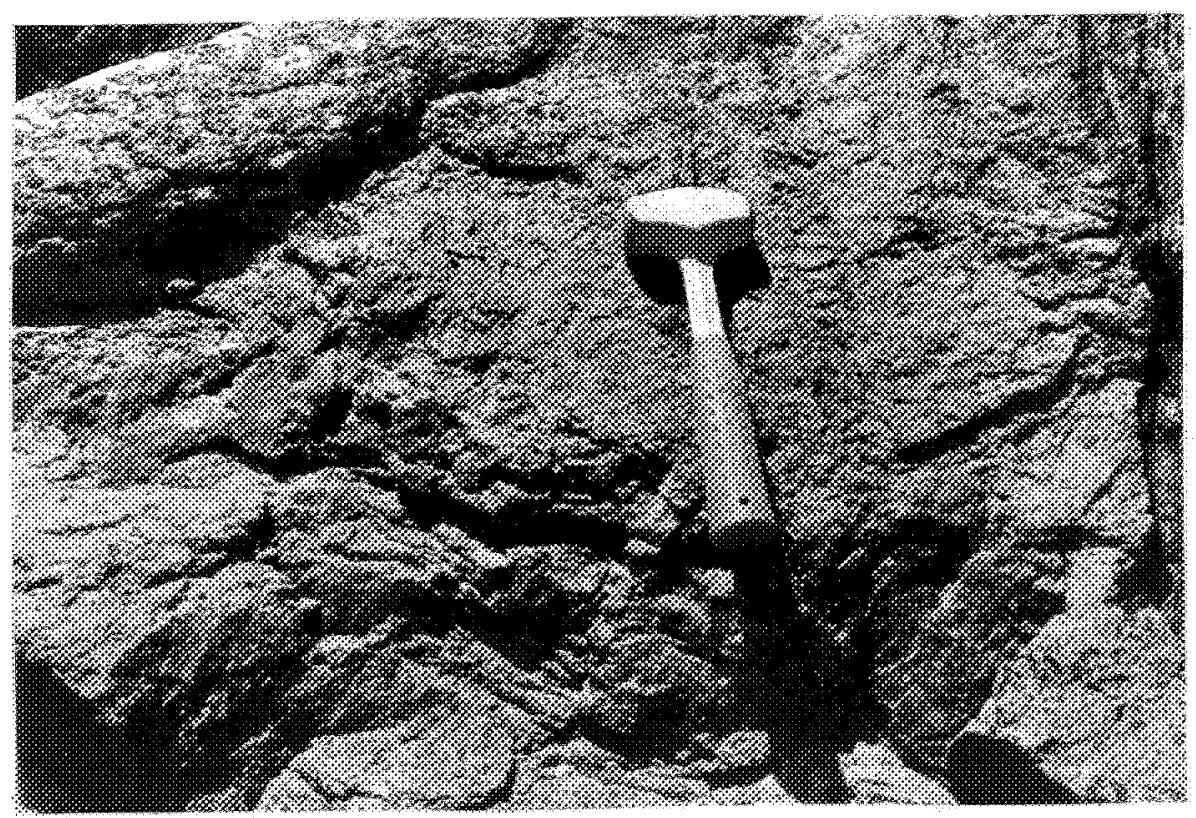




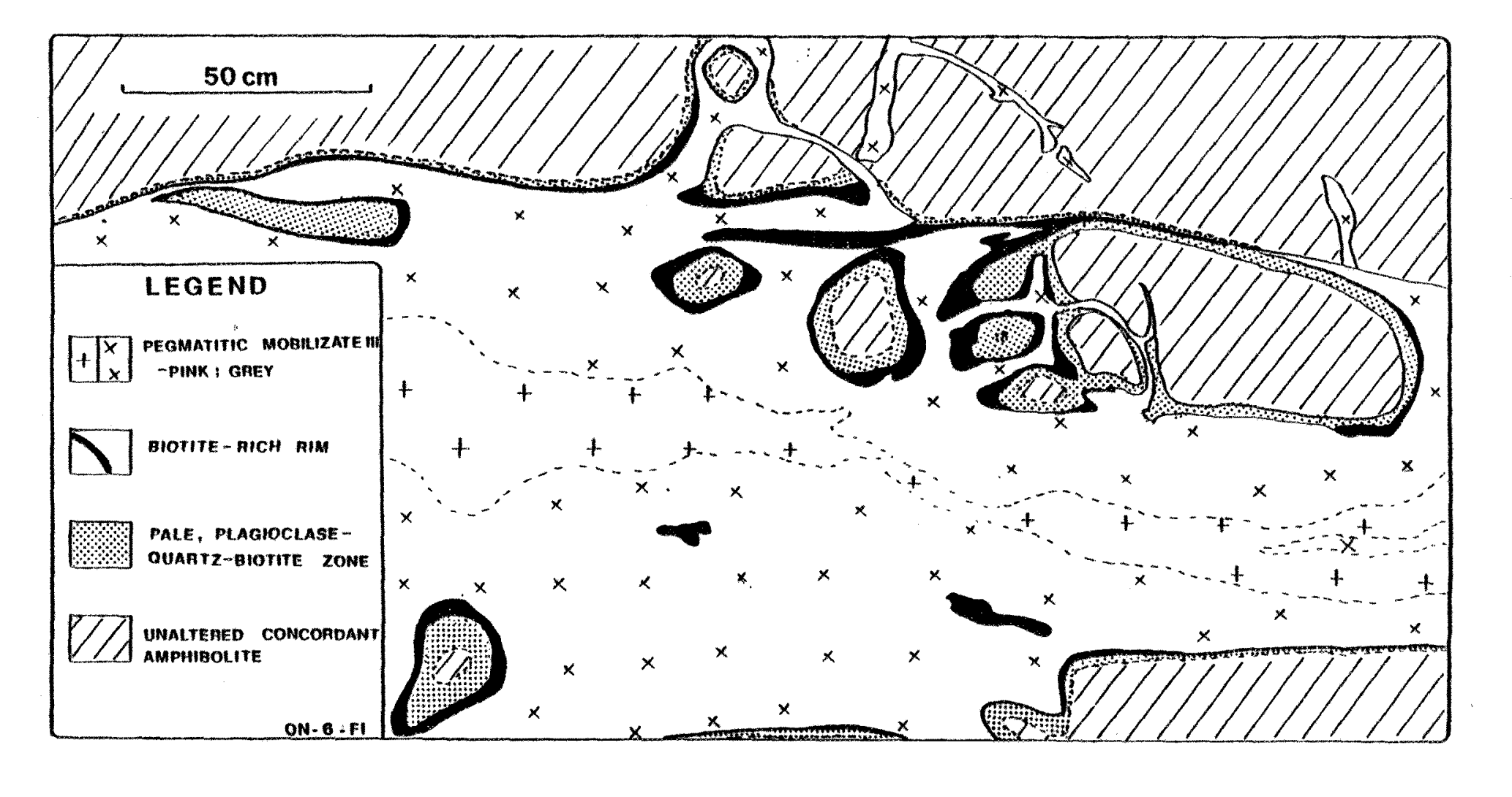




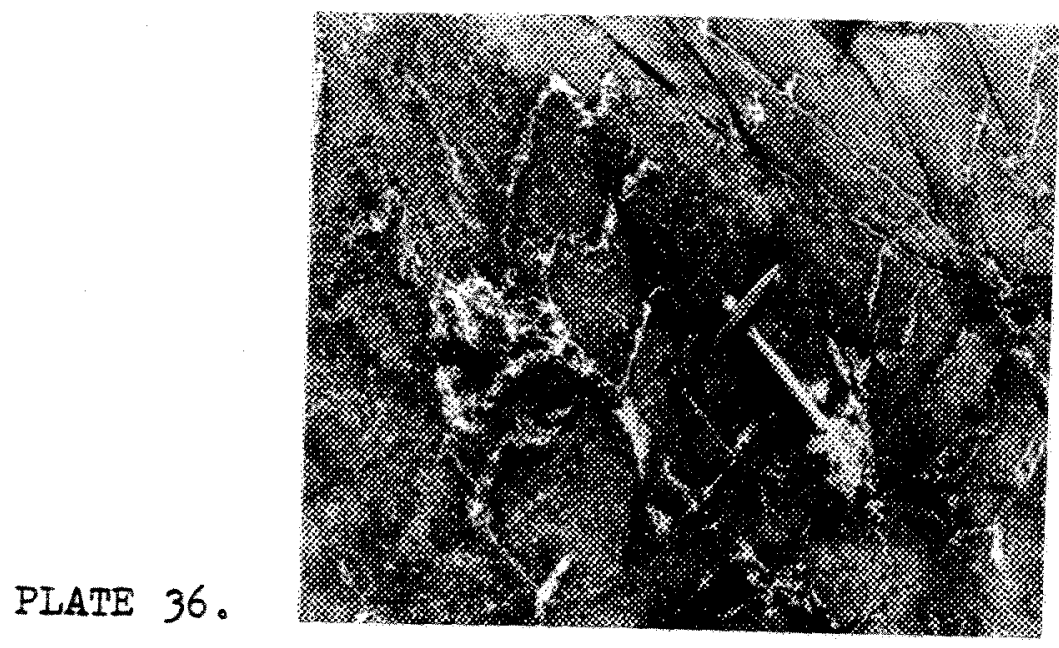

PIATE 37.

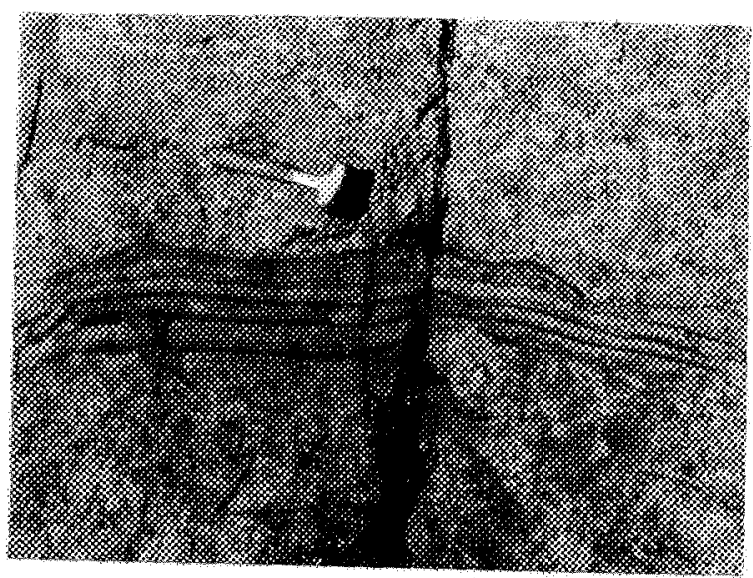


PLATE 38.

a. Hornblende clots developing in a recrystallized zone adjacent to a discordant eranitic mobilizate III vein in eranite I. This vein is oriented at a shallow angle to the outcrop surface, therefore the thickness of the recrytallization zone is exaggerated (actual thickness $-3 \mathrm{~cm}$, roughly equal to the pegmatite vein's thickness). Location:' ON-2.

b. Photomicrograph of ragged horrblende clot in recrystallized granite I described in Plate 30 a. Thin section ON-2-ib. Bar: 2 nim. Plane polarized light.

PLATE 39.
a. Tectonic recrystallization of granitic mobilizate III sheared by S3. Potash feidspar (dark Erey) mezacryst is partly enveloped by quartz plates (white). Thin seciton OSF-1. Refer to Fig. 9 for location. Bar: $2 \mathrm{~mm}$. X-nicols. piagioclase and serrate quartz (white to dark grey) have interstitial mafnetite (black). Refer to plate 14 for outcrop aspect. Thin section ORM-4-7. Bar: $2 \mathrm{~mm}$. X-nicols.


PIATE 38a.

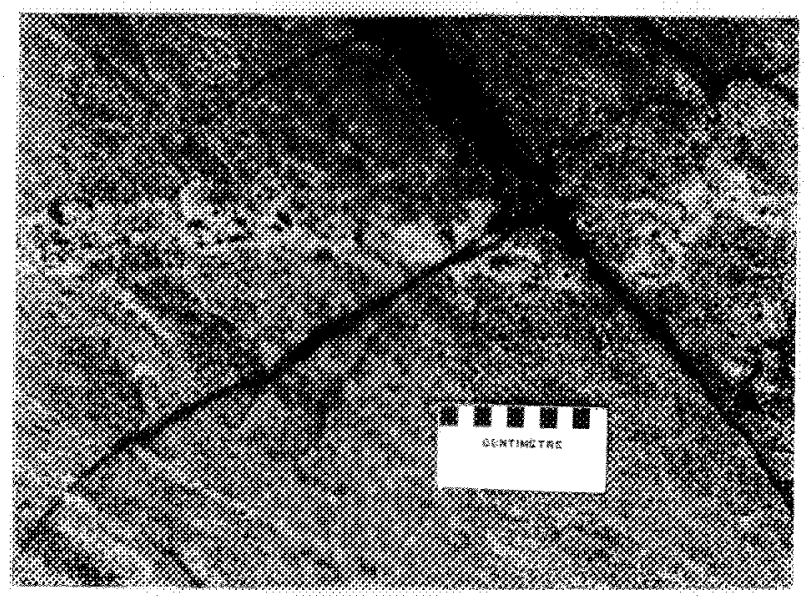

PIATE 38b.

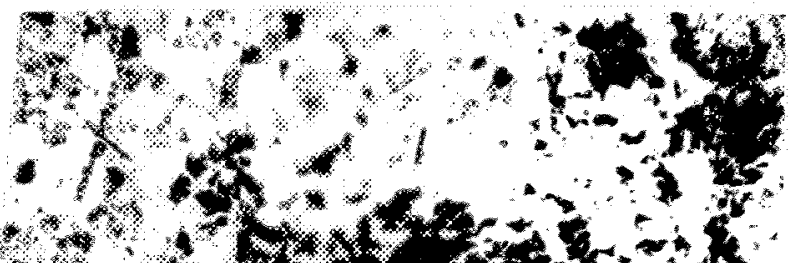
$4+2 \times y^{2}+2$ $42,201 \cos ^{2}$ (1)

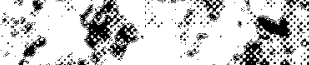

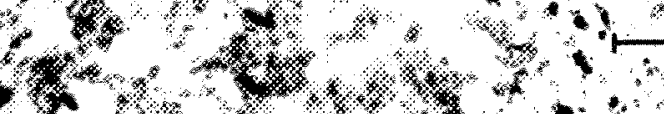

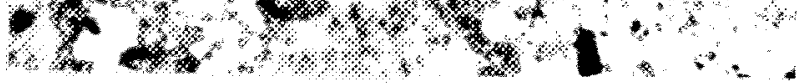

PIATE 39a.

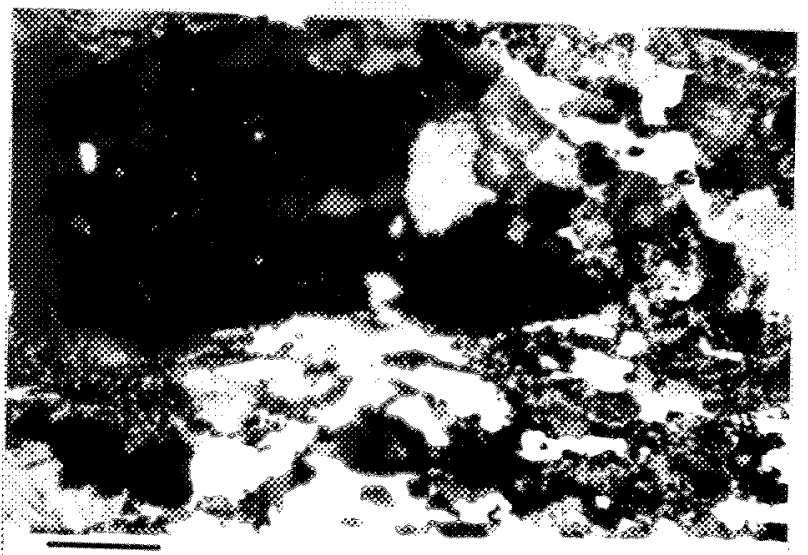

PLATE 39b。

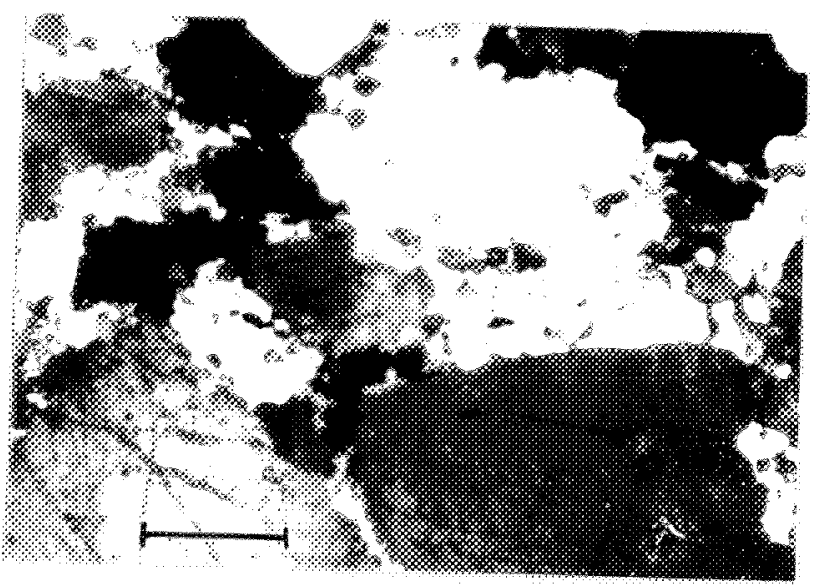


TABLE 11. Mineralogical characteristics of mobilizate III.

Note: all varieties of mobilizate III pegmatites may be found in 211 rooks of age groups I. II and III. Thus, the pegmatites may be described without considering their host rocks. The veins may be described in terms of their mineralogical end members: granitic (thin sections OS-31-2, ORM-3-5, OSF-1, ON-2-1a,b ORM-3-7) and trondh jemitic (OS-1- ON-7-F1b, ON-6-3i, 1 , ORM-4-8, ON-6-6.) Recrystalization effects are noted.

Vein/dyke thickness: $\quad 2 \frac{\text { Granitic }}{\mathrm{cm} \text { to tens of } \mathrm{m}}$ Typical grain size:
To $30 \mathrm{~mm}$

Recrystallization Effects

a) conc amphibolite: biotitization
b) granite I:

c) paragneiss:

form $n$ of ragged mafic clots

biotitization

\section{Trondhjemitic

$$
2 \frac{\mathrm{cm} \text { to }{ }^{2} \mathrm{iew}}{2 \mathrm{ew}^{2} 30 \mathrm{~mm}}
$$

K-Feldspar

Typical grain size:
Grid twin:
Perthite:
Mode of occurrence:
Plarioclase (twinned)
Typical grain size:
2oning:
Myrmekite;
Ateration:
Mode of occurrence:

$5 \mathrm{~mm}$

common

present (patch, string)

large interlocking

irregular grains

1 mita

none

common

absent to slight

subidiomorphic grains

Ratio K-spar/qz/plag

$50 / 40 / 10$

biotitization
not seen
not seen

$0.5 \mathrm{~mm}$

present

absent

smali interstitial

grains

$5 \mathrm{~mm}$

none

present

absent to slight

subidiomorphic grains

$50 / 45 / 5$ (note: in each case, the ratio of gz:dominant feldspar may vary considerably.

\section{Guartz}

Typical grain size: $5 \mathrm{~mm}$

Mode of occurrence: interstitial masses

$5 \mathrm{~mm}$

interstitial masses

Important Accessory Minerals

$\begin{array}{ll}\text { Magnetite: } & 0 \text { to } 15 \% \\ \text { Apatite: } & 0 \text { to } 1 \%\end{array}$

0 to $15 \%$

Apatite:

0 to $2 \%$

0 to $4 \%$

0 to $1 \%$

Note: mineral grain sizes described are, on average, small, since relatively fine grained pegmatites were sampled for thin'section. 
TABLE 12. Comparison of mineralogy and mineral proportions shown by recrystallized concordant amphibolite bordering trondhjemitic mobilizate III. Recrystalization zoning in this example is similar to that depicted in Fig. 34. Thin sections $0 N-6-3(1,1 i)$.

Zones: a) Trondhjemitic mobilizate III

b) Biotitized zone

c) Biotitized zone, relatively leucocratic compared

d) Unaltered concordant amphibolite host

\begin{tabular}{|c|c|c|c|c|c|c|}
\hline Mineral & Zone & $\frac{\text { a) }}{\mathrm{mm}}$ & $\frac{\text { Zone b) }}{m \text { m }}$ & $\frac{\text { Zone }}{6}$ & c) & $\frac{\text { Zone }}{x}$ \\
\hline $\begin{array}{l}\text { Quartz } \\
\text { Plag. } \\
\text { Biotite } \\
\text { Hornbl. } \\
\text { Opaques } \\
\text { Apatite } \\
\text { X-spar }\end{array}$ & $\begin{array}{l}24.0 \\
66.0 \\
5.2 \\
0.2 \\
4.2 \\
0.2\end{array}$ & $\begin{array}{l}10 \\
10 \\
3.6 \\
0.1 \\
0.6 \\
0.4\end{array}$ & $\begin{array}{ll}14.0 & 2.0 \\
10.6 & 1.4 \\
68.6 & 7.2 \\
- & = \\
6.6 & 0.5 \\
- & =\end{array}$ & $\begin{array}{l}25.9 \\
36.8 \\
21.8 \\
1 \overline{4} .5 \\
0.9 \\
-\end{array}$ & $\begin{array}{l}0.4 \\
0.5 \\
0.4 \\
0.8 \\
0.05 \\
=\end{array}$ & $\begin{array}{l}8.5 \\
28.5 \\
3.5 \\
54.0 \\
5.0 \\
0.5 \\
-\end{array}$ \\
\hline & 99.8 & & 99.8 & 99.9 & & 100.0 \\
\hline
\end{tabular}

Note: point count data presented in Appendix 1. 


\section{v. DISCUSSION}

Mechanisms and Fossible Conditions of Migmatization in the Study Area

Genetic interpretation of the mesoscopic occurrences, petrography, and modal compositions of the different generations of mobilizates will be based on the method outlined in Table 4. Insofar as the low metamorphic grade parent rocks of the migmatites of the old Gneiss Complex are unknown, comparison of parent rock-migmatite bulk compositions is not possible, thus, from the outset, it is not possible to distinguish betweer an open and closed system, sensu strictu, for individual generations of leucosome generation. Rather, the scale dependence of the concept of closed versus open systems is called upon in our arguments, and this is indicated, as discussed at length in sections II and IV, by the observations listed in Table 4 , namely, the presence/absence of melanosomes, and mobilizate and plagioclase compositions. Exceptions to a "closed system" environment, on a metre-(outcrop)scale, have been described, and provisions for this are made in Table 4. In fact, distinction between allochthonous and autochthonous leucosomes is amongst the genetic conclusions afforded by research. However, given the scale dependence of the concept, some leeway is justified, and it was possible after preliminary field observations to distinguish between leucosomes of small scale (cm- to $\mathrm{m}$-scale, therefore, essentially autochthonous) mobility and those of clearly intrusive (allochthonous) origin.

Insofar as more data are available for migmatization II leucosomes, these will be evaluated forthwith. The in situ origin of mobilizates II is demonstrated by the mineralogical similarity of these leucosomes with their source paleosome, by the presence of well developed melanosomes, and by melanosome-leucosome plagioclase compositions. Furthermore, from the outset of field examination, it was noted that leucosomes denoted as "mobilizate II" showed a mobility range restricted to a few metres, that is, mobility on an outcrop 
scale. This corresponds with a closed environment of migmatization, according to our definition above. However, in order to meet the definition of closed system in the strictest sense, we must approach the problem directly. If all the material in the neosome may be volumetrically accounted for by segregating neosome components from the adjacent paleosome, a closed system is indicated. Given a closed system, all leucosome material is generated in and segregated from the adjacent melanosome and/or nearby paleosome. However, melanosome thicknesses are usually greatly exceeded by levoosome volumes, indicating leucosome mocility along the length of the vein. For example, given $1 \mathrm{~mm}$ thick melanosomes with a fivefold degree of mafic mineral enrichment over and above the paleosome, we may expect a leucosome thickess not exceeding $1 \mathrm{~cm}$, given a degree of leucocratic mineral depletion in the melanosome roughly equal to the degree of mafic mineral enrichment. However, mobilizate IIc veins commoniy attain thicknesses exceeding $10 \mathrm{~cm}$, and are, nevertheless, bordered by melanosomes $<5 \mathrm{~mm}$ in thickness. As also demonstrated by discordant offshoots from melanosome-seamed concordant veins (Plate 17e), mobilizate II material is clearly mobile on a decimetre to metre scale. Therefore, for vein morphologies, melanosome-leucosome mass transfer calculations are generally not applicable. In one location in the St. Fulgence paragneiss sequence, an isolated zone in arkosic quartzite shows evidence of preferential migration of the feldspar component of the arkose, which segregates to form coarse grained granitic pegmatoid. The pegmatoid is surrounded by a continuous quartzite zone leached of feldspar: this may be considered to be a restite zone (Plate 40). As such, this isolated pegmatoid is ideal material for a mass transfer calculation.

Eigures $35 a, b$ are reduced representations of photographic enlargements of thin sections: ON-3-F4a,b, sampled from the arkosic quartzite and leached quartz illustrated in Plate 40 . From these photographic enlargements, the volume $\%$ of feldspars in each thin section was determined by measuring the surface area covered by 
PLATE 40.

Formation of Eranitic pegmatoid clot in arkosic quartzite The leached zone surrounding the pegmatoid is roughly outined. Location: Or-3. Ear: $10 \mathrm{~cm}$. See text.

FIGURE 36.

Sketch of photographically enlarged thin sections of arkosic quartzite $\left(0 k-3-F_{4} a\right)$ and leached quartzite $(0 N-3-F 4 b)$, iliustrated in Plate 40. 


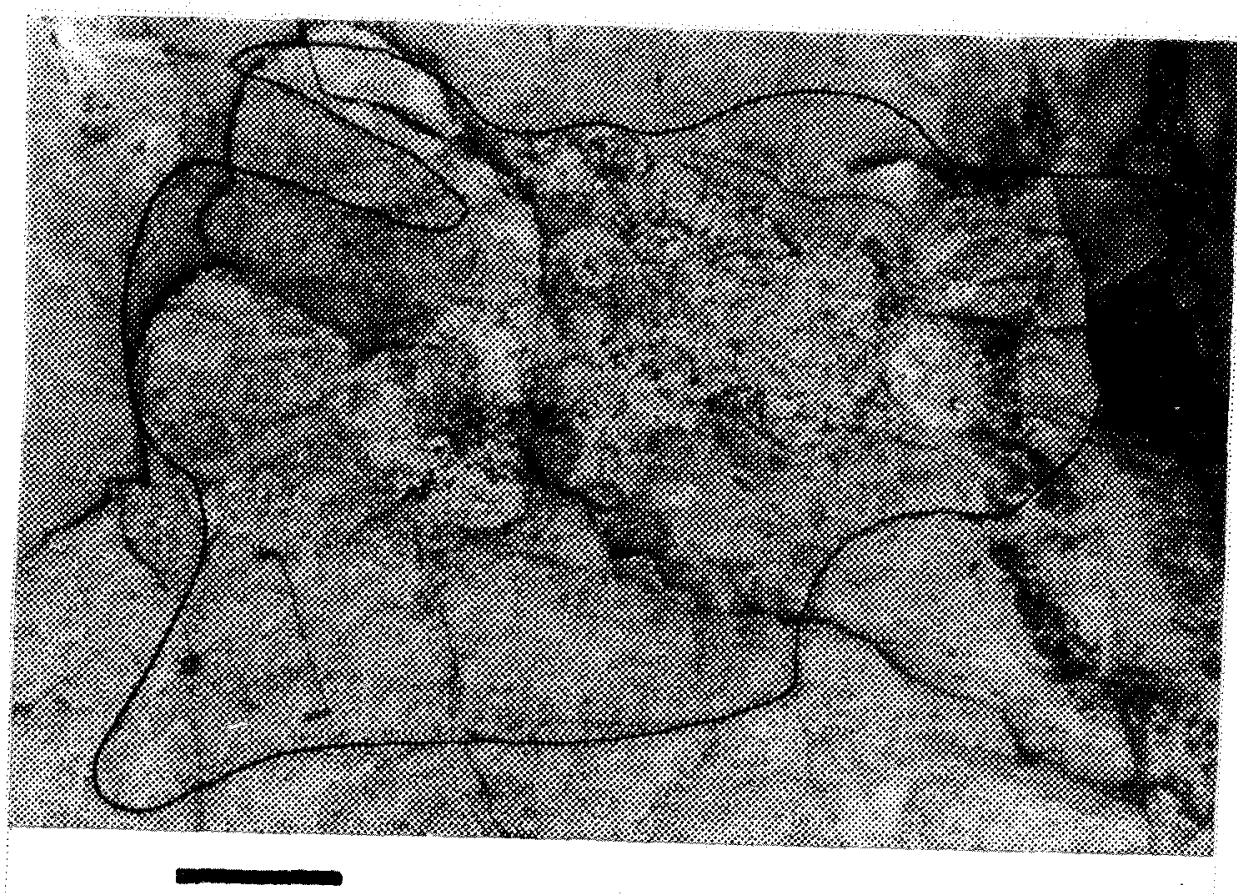

PIATE 40.

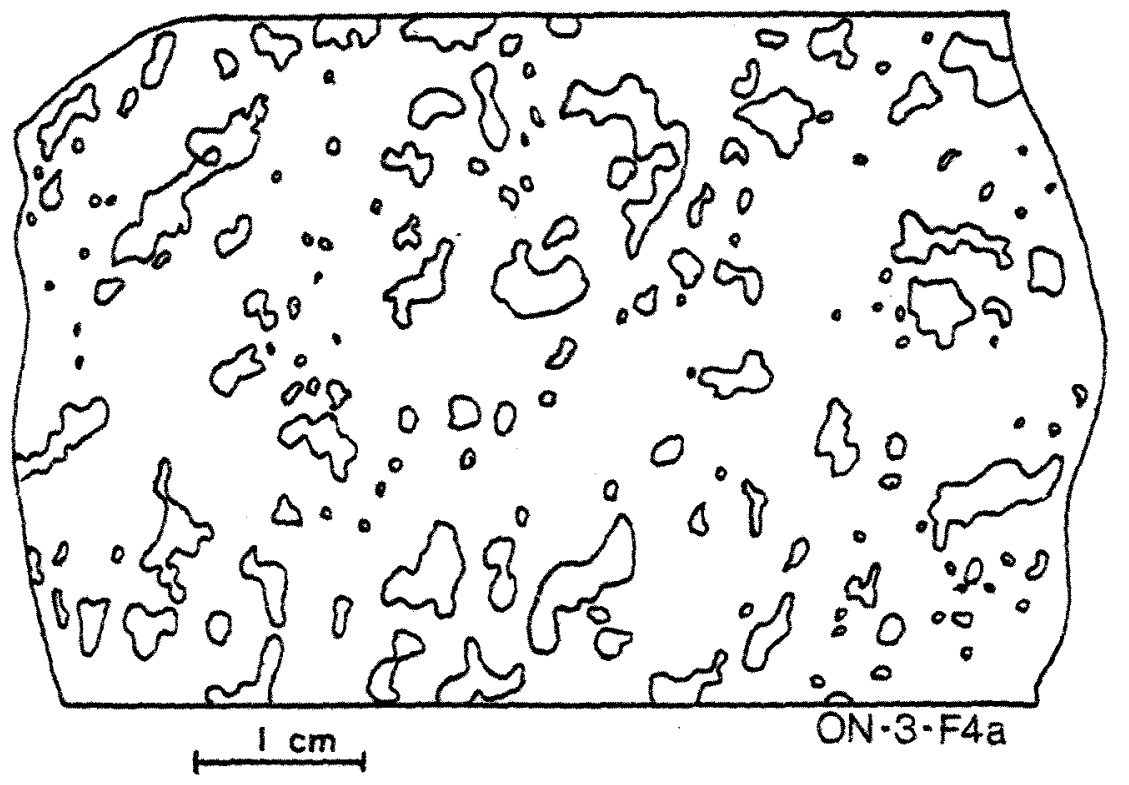

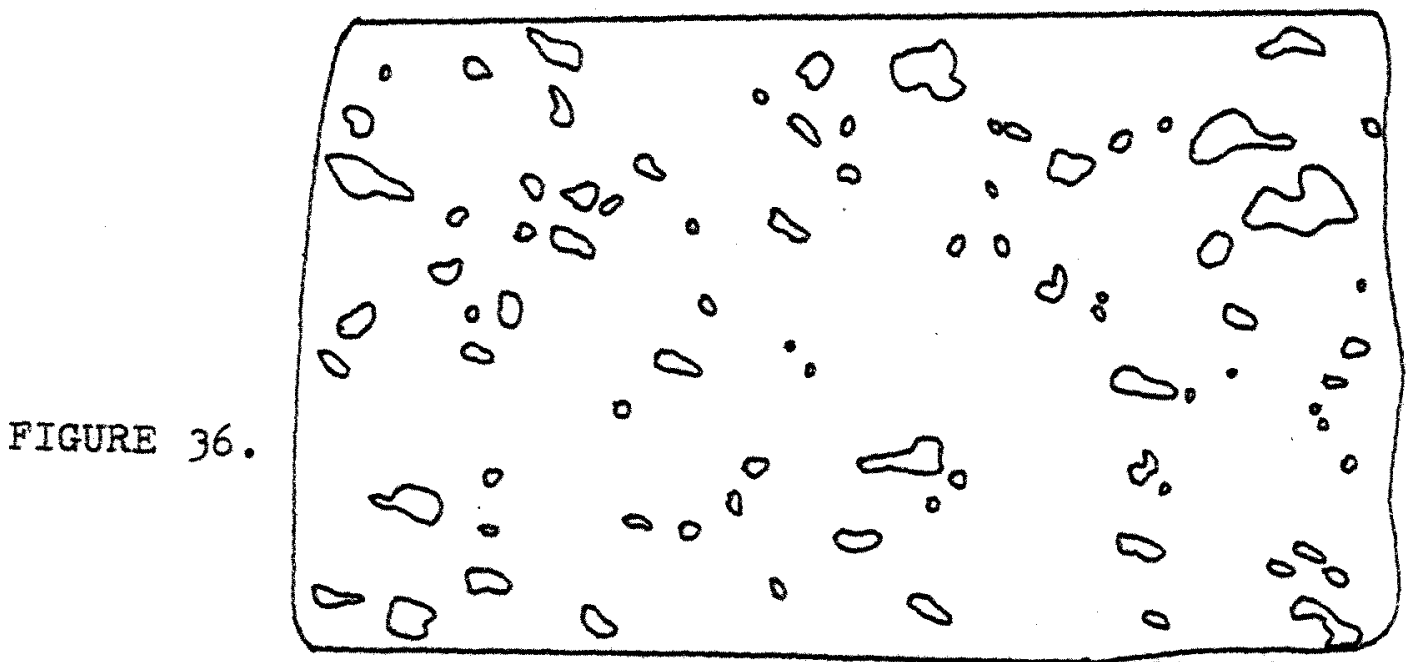


feldspars and comparing this result with the thin section area. The method has been shown to be accurate to within $0.5 \%$ (Dimroth and Owen, 1979, unpublished data). By this method, it is seen that the host arkosic quartzite, as represented by thin section ON-3-F4a, contains 14.4\% total feldspar. The leached quartzite surrounding the pegmatite core (Plate 40) contains 5.9\% total feldspar. Although cuartz may be easily distinguished from potash feldspar in the pegmatite (Plate 40), not all of the quartz may be recosnized in the photograph, therefore the present method is not applicable. However, the potash feldspar content of the pegmatitic mass is visually estimated at $60 \%$ (ie. $40 \%$ quartz).

From an 8" $\times 10^{\prime \prime}$ enlargement of Plate 40 , and after conversion to outcrop scale, it is seen that the leached zone has an outcrop surface area of $-1,224 \mathrm{so} . \mathrm{cm}$. , and the pegmatite has an area of $-427 \mathrm{sq} . \mathrm{cm}$. The accuracy of these determinations relies, of course, on the precision of the line delineating the leached zone from the arkosic quartzite. Although the two zones are quite distinct, based on feldpar content, the contact between the two is fairly diffuse.

The total difference of feldspar content between the host arkose and the leached quartzite within the restite zone is given by:

(1) $(14.4-5.9) / 100 \times 1,224=104 \mathrm{sq} \cdot \mathrm{cm}$.

Referring to Plate 40, it is clear that the leached zone of quartzite ("restite") envelopes the mobilizate. It is reasonable to assume that the thickness of this restite zone, measured along lines radiating from the centre of the mobilizate, is statistically controlled by the diffusion constant of the migrant levcocratic minerals. Also, mobilizate thickness is controlled by the quantity of material diffused along any given direction. As such, the geometry of the mobilizate is not controlled by structures in the paleosome (Plate 40; no structural control on mobilizate localization is apparent). In this case, the volume enclosed by the restite is simply an enlargement of that enclosed by the mobilizate. These volume relations may be described as follows: 
(2) $\frac{\text { Volume (restite }+ \text { mobilizate) }}{\text { Volume (mobilizate) }}=\frac{V 1+V_{2}}{V 2}-f^{3}$

where "f" is the linear enlargement factor.

Assuming that the outcrop surface depicted on Plate 40 is representative of any two-dimensional section through the neosome, we have:

(3) $\frac{\text { Surface (restite }+ \text { mobilizate) }}{\text { Surface (mobilizate) }}=\frac{s 1+s 2}{s 2}-f^{2}$

Substituting with values obtained from the photographic enlargement of Plate 40 , we now have:

(4) $v_{1}-\left(\frac{1651}{427} \sqrt{\frac{1651}{427}}-1\right) v_{2}-6.6 \mathrm{v} 2$

Furthermore:(5a) Volume (feldspar extracted from restite) $=V^{\prime} 1=14.4-5.9 \mathrm{~V} 1$ 100

(5b) Volume (feldspar in mobilizate) $=v^{\prime} 2=\frac{60}{100} v_{2}$

Dividing and substituting values from (4) we have:

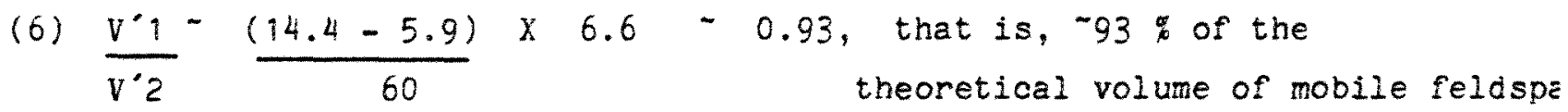

This result demonstrates that the system was closed to the mobile components constituting mobilizate II.

A concordant offshoot from a cross-cutting coarse grained mobilizate IIc pod generated in granite I late during migmatization II is seen to have melanosome plagioclase (An 28) considerably more calcic than leucosome plagioclase (An 12-15). In conjunction with other features noted above, we are led to conclude that polyphase mobilizate II leucosomes are anatectic in origin. This conclusion is in accordance with the demonstrated fluid nature of mobilizate II 
leucosomes, the recrystallization of host rocks by mobile mobilizate II veins, and the clustering of the leucocratic mobilizate components about the cotectic of the system albite-quartz-orthoclase (Fig. 37).

This conclusion may be independantly verified by considering the metamorphic conditions prevalent during migmatization II. Sample $\mathrm{OBH}-1$, from the Ha! Ha! Bay paragneiss sequence (Fig. 1), contains the paragenesis garnet-cordierite-sillimanite-quartz-microcilne-(biotite) (Plate 41a). Figure 38 outiines the positions of phase boundaries of mineral assemblages of this paragenesis; these phase boundaries are sensitive to the $\mathrm{Mg} / \mathrm{Mg}$ + Fe ratio of ferromagnesian minerals in the paragenesis (Hensen and Green, 1971), consequently, given the $\mathrm{Mg}: \mathrm{Fe}$ ratio of cordierite, the $P I$ conditions of the above mineral assemblage may be estimated. A straight line relationship exists between different cordierite compositions and the $\beta$ refractive index (Miyashiro, 1957). The $\beta$ refractive index of cordierite from sample OBH-1 was determined to be 1.546 by oil immersion. Although the powdered cordierite contained quartz, the two minerals are easily distinguished since the cordierite contains penetration twins, and has, of course, a biaxial optic-axis figure for $\beta$ sections. This corresponds with an $\mathrm{Fe}$ content of approximately $40 \%$ for metamorphic cordierites (Fig. 39). The paragenesis garnet - cordierite sillimanite - quartz - microcline - (biotite) in thin section OBH-1 shows evidence of prograde-retrograde reactions. Both the paleosome and leucosome (mobilizate IIa) show similar textural features. Two types of almandine (almandine-pyrope?) garnet are present: an earlier generation of garnets, completely altered to chlorite, subsecuently to sericite, and larger, more abundant porphyroblastic garnets, with inclusions of sillimanite, quartz, and opaques + dark green isotropic spinel (Plate 41a). There is good textural evidence for the retrograde reaction (Fig. 38, curve 3 ):

(7) cordierite + almandine + K-feldspar + V----- biotite + quartz + sillimanite 
here; the forward reaction products occur as platy intergrowths of biotite and ouartz (Plate 41b), and sillimanite and ouartz (Plate 49). An earlier generation of sillimanite is indicated insofar as idiomorphic sillimanite crystals locally occur as inclusions in biotite-auartz platy intergrowths (Plate 41) and in porphyroblastic garnet. As such, considerable quantities of sillimanite survived the prograde (reverse) reaction (7), above, by being isolated in parnets and, to a lesser extent feldspar and biotite. The virtual absence of muscovite, and the predominance of $\mathrm{K}$-feldspar and sillimanite in the paragneisses indicate the source of this early sillimanite: the reaction (Fig. 36 , curve 2)

(8) muscovite + auartz-----> K-feldspar + aluminosilicate + V

The small amounts of muscovite locally seen in the paragneisses is of retrograde origin. Locally, muscovite forms by pressure-solution alteration between mortar-textured garnet or feldspar porphyroblasts, or by sericitization of feldspar, or chlorite. Reaction (8) sillimanite is common in melanosomes bordering mobilizate $I$ veins in the paragneiss.

A relict of the retrograde reaction (7) is illustrated as Plate 410. Here, garnet porphyroblasts mimic the retrograde biotite-auartz platy intergrowths. These same garnets may contain retroerade biotite (Plate 4 (e).

As such, the anatectic conditions responsible for migmatization II fall close to the reaction (7) phase boundary as shown in Fig. 37 (curve 3). Given a cordierite Fe-content of approximately 40\%, we concluis anatectic conditions in the order of 750 to $800 \mathrm{C}$, at about $5.5 \mathrm{~kb}$ (1) These conditions represent a culmination of metamorohism in the study area. Retrograde mineral reactions affecting parageneses formed in ecuilibrium during peak metamorphic conditions include, in addition to reaction (7), the subsolidus transformation of anatectic (?) clinopyroxene to an intergrowth of hornblende and quartz (Plate 25) in concordant amphibolite, the mantling of orthopyroxene by hornblende in charnockite (Plate 10),

(1)

These represent maximum PT conditions. $\mathrm{PH}_{2} \mathrm{O}$ may well have been less than Ptotal: for $\mathrm{PH}_{2} \mathrm{O}=0.4$ Ptotal, $\mathrm{T} \sim 700-7500 \mathrm{C}, \mathrm{P} \sim 5 \mathrm{~kb}$ for this composition of cordierite. The survival of prograde sillimanite (reaction 8 ) during/following mobilization II suggest low $\mathrm{PH}_{2} \mathrm{O}$, by virtue of the lack of sillimanite muscovitization by reaction with $\mathrm{K}^{+}+\mathrm{H}_{2} \mathrm{O}$. K-feldspar rich mobilizates II indicate a high $\mathrm{K}^{+}$activity; aqueous fluids liberated during mobilization II may have largely been taken up as fluid inclusions in quartz and feldspar and in hvdrating pvroxenes. 
exsolution features and the manting of microcline by albite juxtaposing oligoclase (Plate 23a), and various alteration processes: incomplete biotitization, chloritization, uralitization, and saussuritization. Equally important is the partial tectonic recrystallization of paleosome and neosome components of rocks of age groups I and II, leading variously to the development of granoblastic, mortar, augen, and flaser textures (Table 7).

Wylie (1977, p. 65) has demonstrated that, "in the presence of excess H2O, curves for the beginning of melting of granite, tonalite and sabbro (amphibolite)...are not widely separated, and they are exceeded by most of the paths of metamorphism". Consequently, given the proposed anatectic origin of mobilizate II segregations in rocks of age groups I and II, one may tentatively conclude that the trondhjemitic mobilizate II leucosomes in concordant amphibolite, and in some dyke amphibolites, are also anatectic. However, a metamorphic segregation mechanism may not be excluded, since, as indicated in section III, anatexis of rocks relatively poor in potassium nevertheless yielos partial melts which crystallize considerable quantities of potash feldspar. Helz (1976) describes the partial melting of tholeiite, olivine tholeiite, and alkaline basalt at 5 $\mathrm{kb}, 680$ to $1,045 \mathrm{C}$, at $\mathrm{f02}$ of the ouartz-fayalite-magnetite and the hematite-magnetite buffer. Except for Na/Ca ratios, the composition of the partial melts does not vary considerably with the bulk composition of the starting material for degrees of partial melting $<70 \%$. Basalts and amphibolites devoid of potash feldspar yield first partial melts generated from the sodic and potassic components of paleosome plagioclase (Wyllie, 1977). Significant melting of hornblende, at pressures of $5 \mathrm{~kb}$, does not occur until $-1,000 \mathrm{C}$ (helz, 1976). The invariable presence of both hornblende and biotite in autochthonous concordant amphibolite leucosomes demonstrates that PT conditions attained during migmatization II lay within the stability fields of both minerals in this lithology. Textural evidence suggests that all biotite in concordant amphibolite is primary, and the survival of hornblende during migmatization is indicated by the rarity of clinopyroxene and the absence of olivine, both which would be common had reaction (9) taken place on a widespread scale. 
(9) hornblende (a)-----> hornblende (b) + augite + olivine + melt (Wyllie, 1977; Helz, 1976)

Although olivine is indicated in the forward reaction, it becomes a significant product only in advanced stages of melting (Wyllie, 1977), therefore its absence within amphibolites in the study area does not preclude the possibility that the clinopyroxenes locally seen in mobilizate II (Plates 25 and 30 ) are anatectic. The demonstrated presence of retrograde biotite in mobilizate II in paragneiss (Plate $41 \mathrm{~b}$ ) indicates that in all rocks excepts amphibolites, anatexis was initiated by prograde dehydration reactions, resulting in anhydrous equilibrium mineral assemblages at the height of metamorphic conditions (eg. garnet-sillimanite-cordierite-quartz-feldspars). Excess water conditions during migmatization II are not indicated for concordant amphibolite. At 5 to $6 \mathrm{~kb}$, the melting interval for amphibolite below the hornblende-out curve is from about 750 to 1,000 $C$, with the inception of clinopyroxene at about $960 \mathrm{C}$ (Wyllie, 1977, Fig. 8). Within this field, hornblende + plagioclase + melt + V coexist, with plagioclase exiting at about $900 \mathrm{C}$. Without excess water, but with sufficient water to maintain hydrous minerals in the amphibolite, at $5 \mathrm{~kb}$ small quantities of water-undersaturated melt are generated at about $950 \mathrm{C}$, clinopyroxene being introduced at this point, and hornblende exiting at about 1,000 C (Wyllie, 1977, Fig. 9). These latter conditions do not produce the mineral assemblages commonly seen in concordant amphibolite leucosomes. Consequently, it may be concluded that migmatization II in the study area produced leucosomes in concordant amphibolite whose composition was controlled by the plagioclase and lesser amounts of quartz in the paleosome. Except for clinopyroxene bearing leucosomes, a process of metamorphic segregation is indicated for amphibolites during migmatization II. This is further substantiated by the quartz-rich nature of these mobilizates (Fig. 37), given the quartz-poor anphibolite paleosone. 
Having considered the origin of migmatization II leucosomes, the genesis of mobilizate I may now be discussed. As indicated in Fig. 37, mobilizate I veins show marked differences in plagioclase:potash feldspar contents in different paleosomes. Furthermore, these points do not cluster near the granitic minimum melting cotectic shown superimposed on the plagioclase-quartz-potash feldspar diagram (Fig. 37). Unfortunately, melanosomes are poorly developed in most mobilizate I neosomes, therefore a comparison of the albite content of melanosome plagioclase with leucosome plagioclase could not be undertaken. Nevertheless, the quartz-plagioclase-(microcline) rich nature of mobilizate I in granite I, compared with the quartz-microcline rich mobilizate IIa material within the same sample $(\mathrm{ON}-2-6)$ indicates that these two generations of leucoscmes have different origins. More specifically, in the absence of compositional and morphological data afforded by mobilizate II material, we may tentatively ascribe a process of metamorphic segregation for generating mobilizate I veins. As in the case of mobiliate II, an in situ origin is reflected by the presence of relict melanosomes, and the compositional similarity between leucosomes and paleosomes. Thus, while granodioritic veins occur in granite $I$, trondhjemitic veins occur in concordant amphibolite. Note the similarity of mobilizate $I$ and II compositions in amphibolite (Fig. 37; only the quartz : plagioclase ratio varies). Equilibrium metamorphic mineral assemblages formed during migmatization I appear to have survived subsequent anatectic conditions, insofar as only the mobilizate II component of any gneiss is, as a result of crystallization from a partial melt, coarse grained. As a consequence of polygonization of mineral mosaics by tectonic recrystallization, the spatial distribution of mobilizate $I$ grains is not genetically significant, therefore the type of investigation proposed by Kretz (1966, 1969 ) is not applicable to this material. However, the presence of sillimanite as the dominant melanosome mineral, and its sporadic occurrence in mobilizate $I$ in paragneiss, indicates that the prograde reaction (2) occurred during or prior to mobilizate I genesis. The absence of granoblastic garnet and cordierite, and the presence of prograde biotite indicate that PT conditions of reaction (7) were not attained. Therefore, subanatectic conditions of -650 to $700 \mathrm{C}$ and 3.5 to 
$4.5 \mathrm{~kb}$ are indicated for migmatization $I$, as represented schematically on Fig. 38. Thus, migmatization I may be placed within the framework of a major period of prograde metamorphism and related deformation, spanning deformations I to IIc (Table 1).

Allochthonous leucosomes include mobilizate III pegmatites and granitoids, and relatively rare microcline-bearing quartz rich veins seen in some amphibolite dykes (eg. Table 9-4). The quartz rich nature of the latter indicates a possible origin by external metasomatism (Table 4 ). However, the extreme rarity of such veins indicates that this mechanism was operative on a very restricted scale. On the other hand, mobilizate III pegmatites and granitoids are clearly intrusive (Plate 42). The compositional range of these intrusives, from granitic to trondhjemitic, and the local occurrence of cross-cutting pegmatites, and pegmatites-granitoids (Fig. 22) indicate polyphase mobilizate III injection. A plutonic source for this material has not been identified, however, the large volumes of granitic pegmatite along the eastern part of the ON-section demonstrates the volumetric importance of mobilizate III, and indicate mobility of considerable scale, possibly in the kilometre range. Morphologically, mobilizate III pegmatites do not create the typical features of migmatitic terrains: veined gneisses, agmatites, nebulites etc. are not seen. Nonetheless, the effects of pegmatite injection are widespread. Paleosomes and inclusions are cross-cut and recrystallized. Granulite-grade mineral assemblages (eg. orthopyroxene-bearing assemblages) are absent from mobilizate III leucosomes, therefore pegmatite injection probably occurred at amphibolite or upper amphibolite grades, reflecting diminishing metamorphic conditions following the culmination during migmatization II. 
PLATE 41. Textures of the paragenesis Farnet-cordierite-microcline retrograding to biotite-sillimanite-quartz, in paragneiss Thin scales are i mm. AlI photos from mobilizate IIa except for $41 \mathrm{~b}$ (paleosome).

a. Overview of the mineral assemblafe garnet (a), cordierite (c), sillimanite $(s)$, cuartz $(q)$, perthitic microcline $(p)$, and biotite (b). M=myrmekitic intergrowth of quartz and plagioclase. Biotite at upper right of photo shows same retrograde platy guartz-biotite intergrowth as shown in 410 . Note proarade (reaction 8 see text) sillimanite inclusions in garnet. Some garnet porphyroblasts have been outined to aid distinction from extinct cordierite, perthite, and quartz.

b. Fetrograde platy quartz-biotite intergrowth. Note inclusions of prograde silimanite. "Hollow" sillimanite cross sections contain quartz, and are probably retrograde (reaction 7 , see text).

c. Platy sillimanite-quartz intergrowth. This is probably a longitudinal section of "hollow" sillimanite cross sections as seen in 416 .

d. At left in photo, garnet (dark grey) contains streaks of cuartz (white), thereby mimicking the biotite (even grey)-quartz platy intergrowth at extreme left. At right centre of photo is silimanite (medium speckled grey).

e. Sillimanite (medium speckled grey) inclusions in garnet (dark grey). Retrograde biotite (even erey, basal cleavage) is seen in Earnet. 
PIATE 41a.

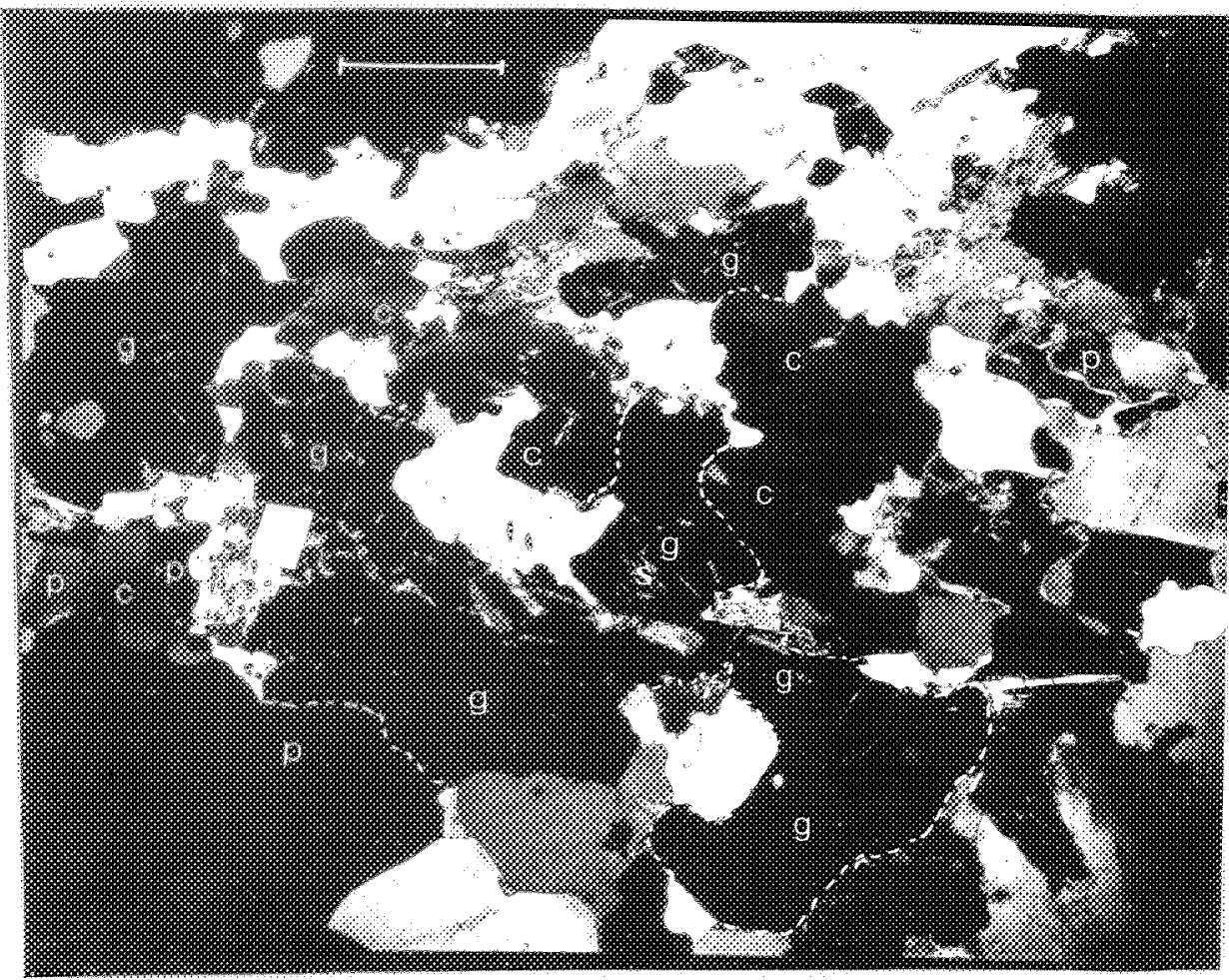

PIATE $41 \mathrm{~b}$.

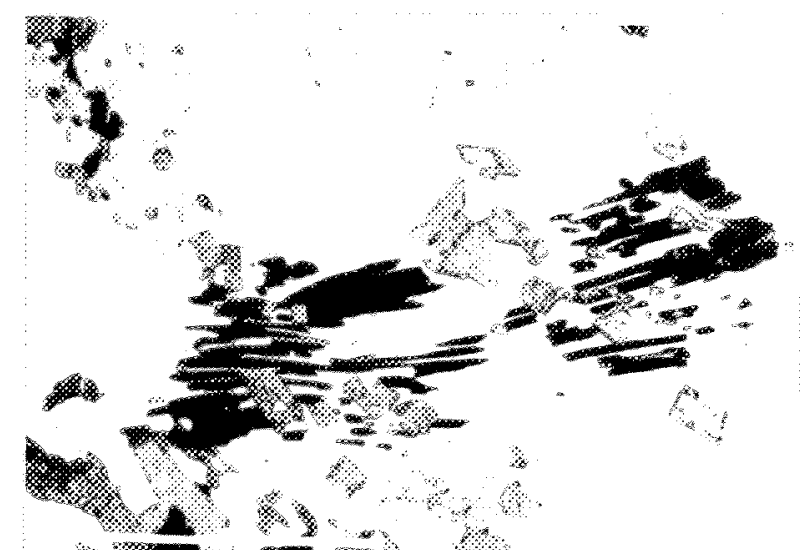

PIATE $41 \mathrm{c}$.

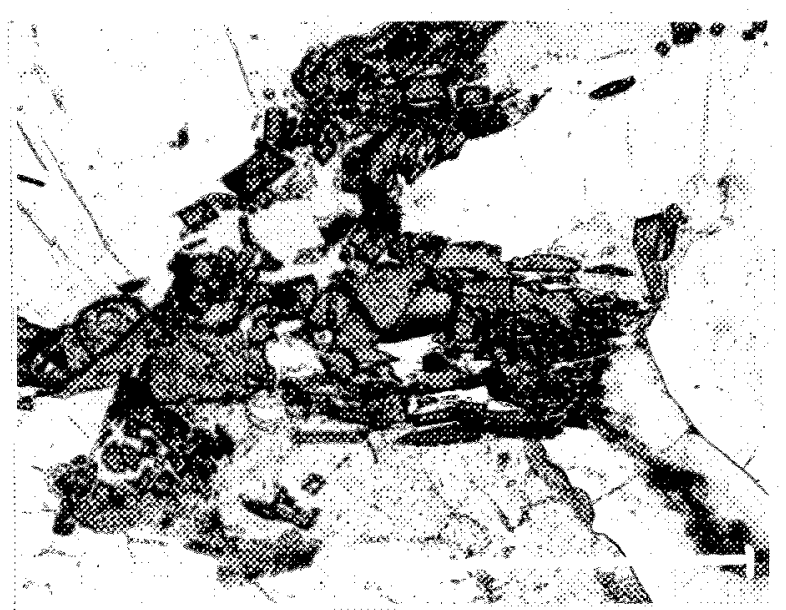


PLATE 410.
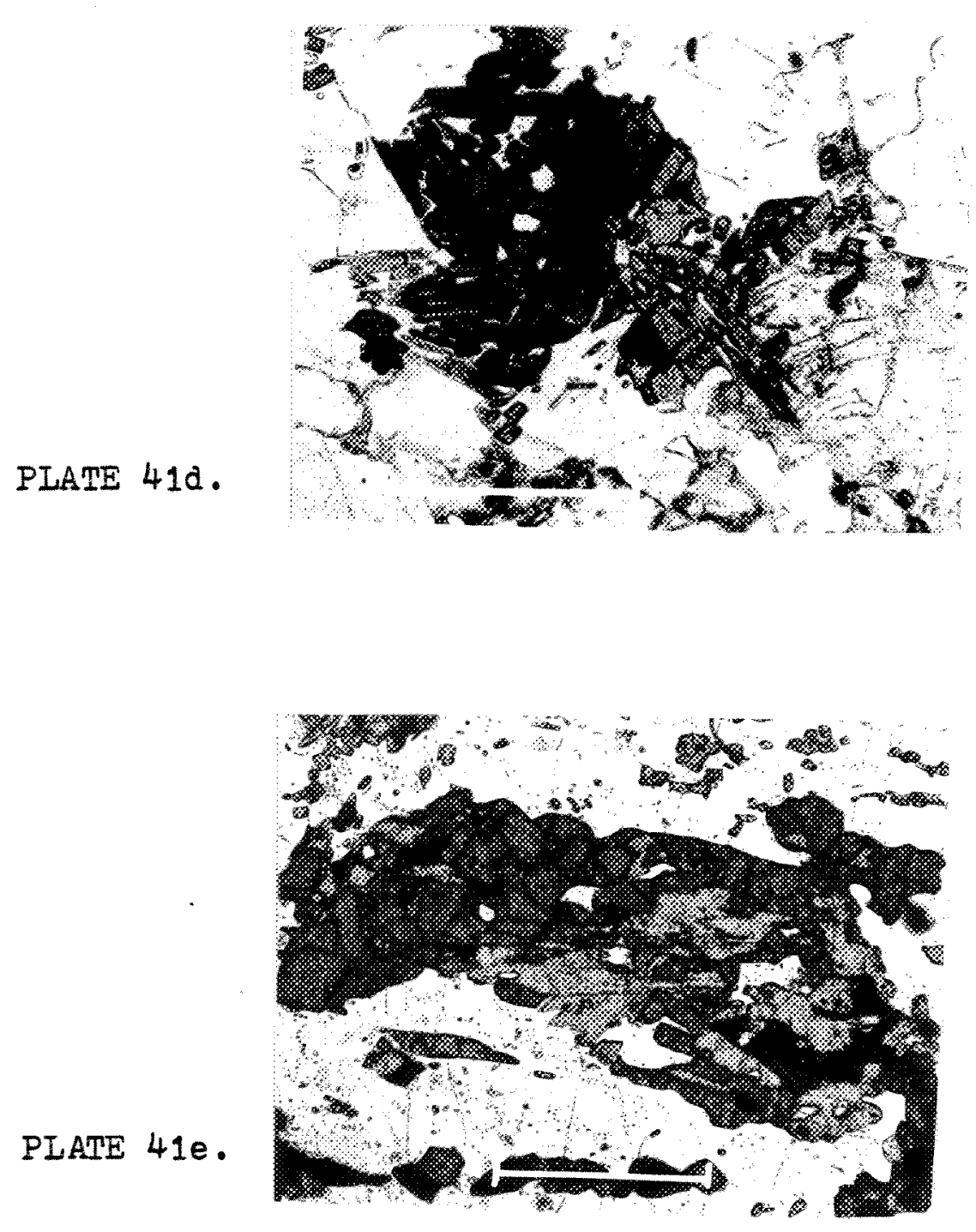


\section{FIGURE 37.}

Quartz-plagioclase-potash feldspar ratios of mobilizates I and IIa in different paleosomes. Superimposed on the graph is the cotectic of the hydrous artificial system quartz-albite-anorthite-orthoclase (Winkler, 1979). The cotectic passes through the composition of mobilizate IIa in granite I, which contains sodio oligoclase. In the absence of analyses of these leucosomes, it can nevertheless be seen that mobilizate IIa leucosomes cluster near the cotectic, whose position is highly pressure dependant. Note that concordant amphibolite leucosomes fall on the plagioclase-quartz join. The quartz-aibite-potash feldspar (H20) system does not, in itseif, adequately explain natural rock partial melting: missing is the anorthite component, however, given a range of plagioclase compositions for leucosomes of different parentage (ie albitio oligoclase in granitic gneiss leucosomes to labradorite in amphibolite leucosomes), it is useful to compare quartzifeldspar contents of leucosomes for different paleosomes on the same two-dimensional diagram. Winkler's cotectic is determined at $P(120)=5 \mathrm{~kb}$; temperatures noted on graph.

\section{FIGURE 38.}

Proposed anatectic conditions operative during migmatization II (heavy stippling). Schematic representation of tentative metamorphic conditions of migmatization I is shown as fine stipoling. Curves 1 and 4 after Dalimeyer and Dodd (1971). Curves 2 and 3 after Holdaway and Lee (1977). Note that the position of curve 4 is highly variable, according to whole rock composition, $\bar{P}(\mathrm{H} 2 \mathrm{O}), \bar{P}(\mathrm{CO} 2)$, etc. See text for explanation.

\section{FIGURE 39.}

Approximate iron content of cordierite from the paragneiss sequence at Ha! Ha! Bay. A $\beta$ refractive index of 1.546 was determined by oil immersion. Graph after Miyashiro, 1957, for metamorphic cordierites. Cordierite from a sample of paragneiss provided by $G$. woussen from ORM-2 has a $\beta$ refractive index of $1.546+0.001$. This method provides but a rough estimate of cordierite Fe:Mg ratio, since the $\beta$ refractive index varies with the contained water content.

\section{PLATE 42.}

Cross-cutting granitic pegmatite dykes (mobilizate III), just west of the ON section. 


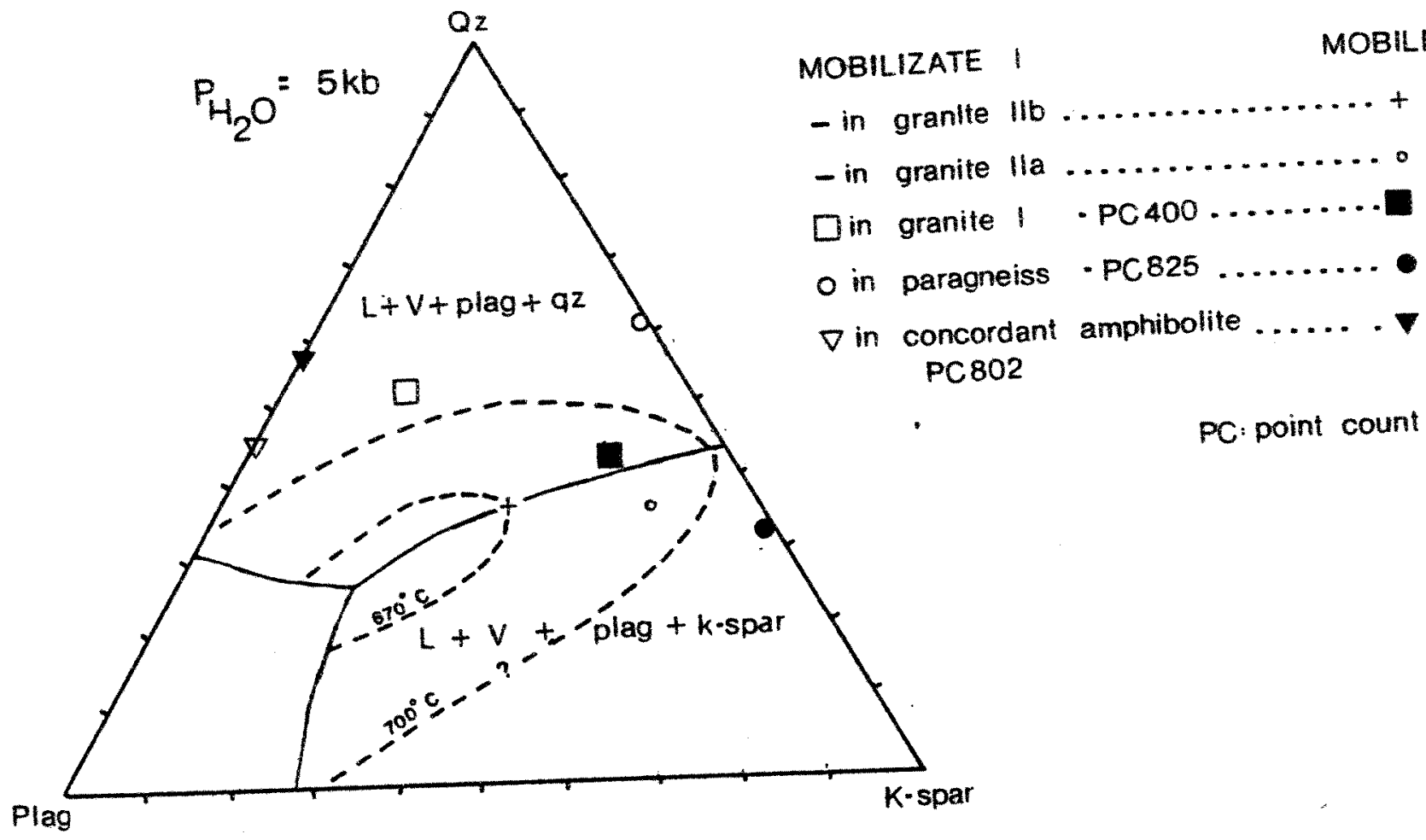

FIGURE 37 . 


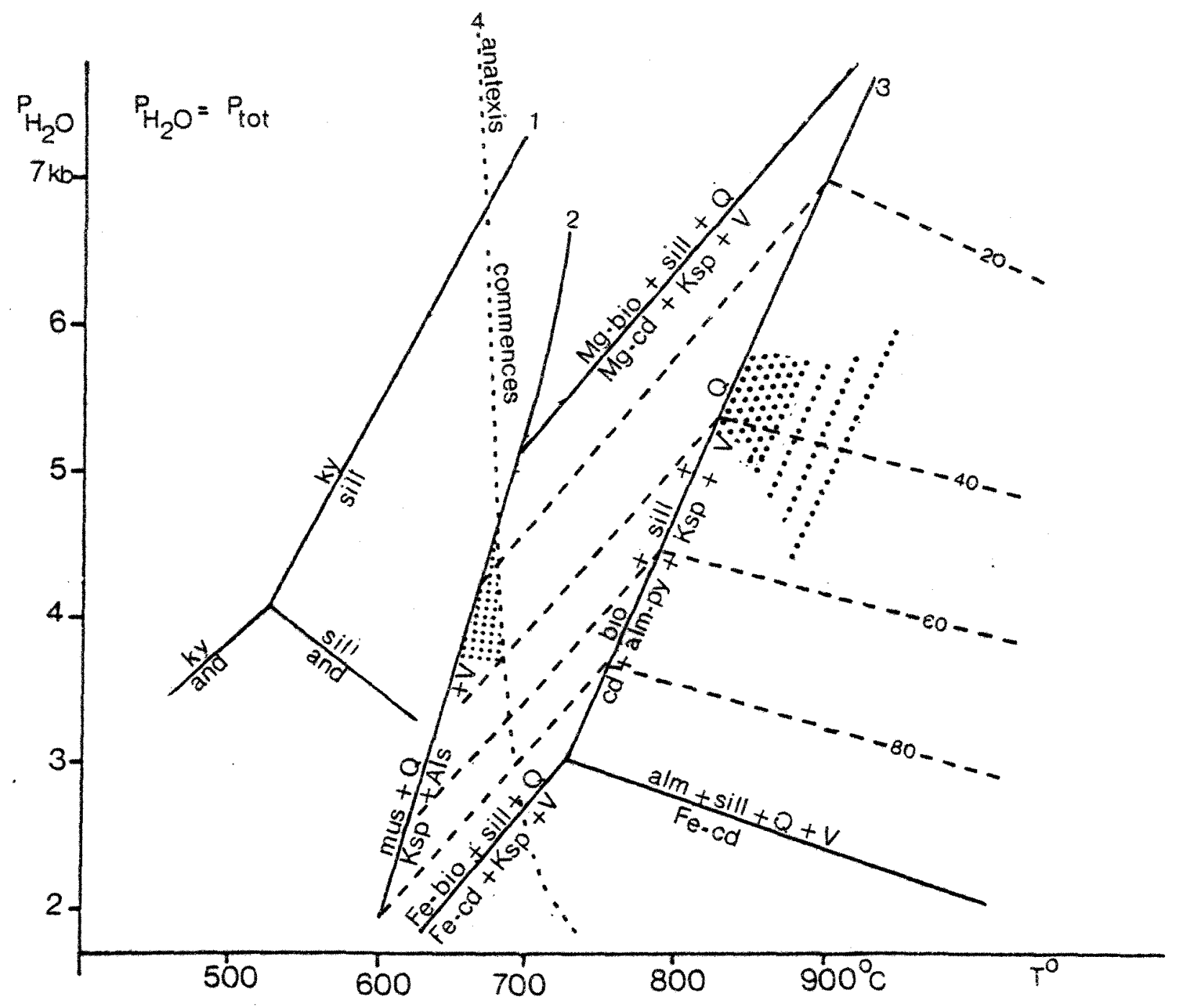

FIGURE 38 . 


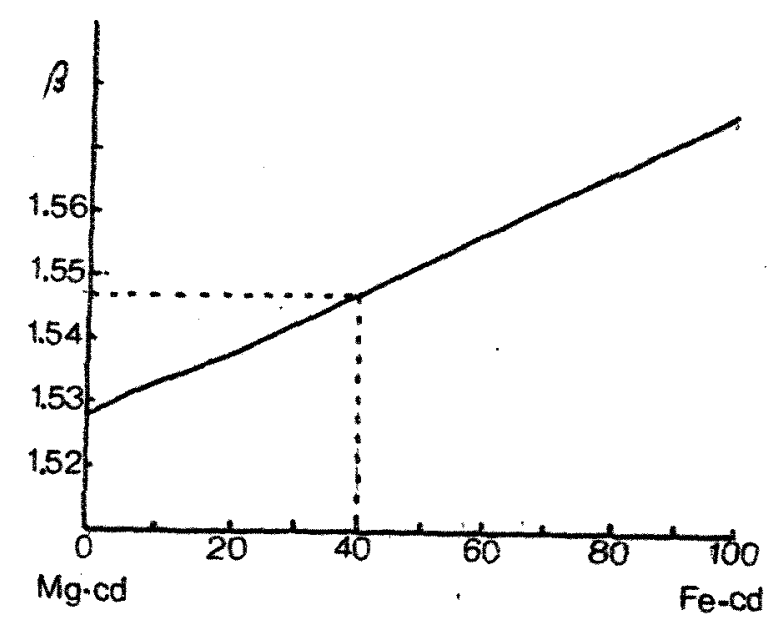

FIGURE 39.

PIATE 42.

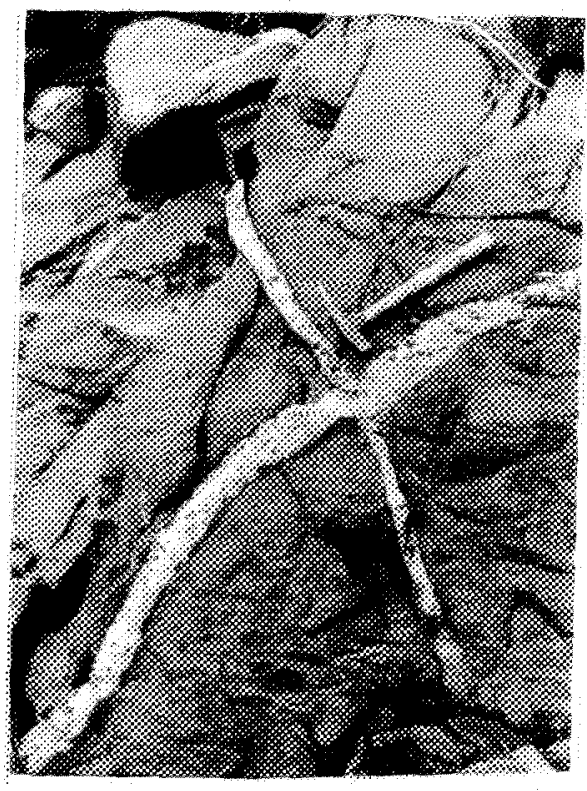




\section{CONCLUSIONS}

Mechanisms and Possible Conditions of Migmatization in the Study Area

Three periods of leucosome generation may be recognized in rocks of age groups I and II of the migmatitic old Gneiss Complex. Recognition of different mobilizate generations relies on cross-cutting relationships and the relation of mobilizate localization to tectonic structures in paleosomes and host rocks. Petrographic parameters may be summarized on the basis of a limited number of these observations, so recognition of different generations of mobilizates may be extrapolated to the general case.

The presence of relict melanosomes, and the similarity of leucosome and paleosome mineralogy indicate that mobilizate $I$ formed in situ. These leucosomes do not approximate minimum melt compositions expected from their various paleosomes, therefore it is suggested that mobilizate I veins are products of metamorphic segregation.

Migmatization II consists of polyphase leucosome mobilization. Early mobilizate II veins (mobilizate IIa) are localized in flexural openings of the dominant $\mathrm{S} 2 \mathrm{a}$ schistosity in the study area. These veins are tightly folded by F2b. Mobilizate IIb veins are localized along strain slip shear surfaces paralleling axial planes of F2c folds which refold F2b. The last leucosomes mobilized during migmatization II form coarse grained discordant pods which cross-cut F2b folds and $S 2 c$ axial surfaces. These mobilizate IIc pods have concordant offshoots which, like mobilizate IIa, have well developed melanosomes. From one of these veins, melanosome plagioclase is markedly more calcic than plagioclase in the adjacent leucosome. This fact, coupled with the fluid nature of mobilizate II leucosomes, which not uncommonly form discordant veins and may infiltrate brecciated interbands occurring locally in their paleosome source rocks, indicates that these segregations are anatectic. The similarity of leucosome mineralogy with expected minimum melt compositions generated from their respective paleosomes, and mass transfer considerations support this conclusion, indicating anatexis in a closed system. Mobility of leucosomes ranges from a few centimetres to several metres. Conditions of anatexis may be estimated from the paragenesis 
cordierite-garnet-microcline, retrograding to bjotite-sillimanite-quartz. The cordierite has an Fe:Mg ratio of $-4: 6$, therefore, migmatization II conditions are believed to have been in the range of 750 to $800 \mathrm{C}$, at about $5.5 \mathrm{~kb} \quad(15$ to $20 \mathrm{~km})$. With the exception of refractory amphibolites, anatexis was initiated by dehydration reactions. Concordant amphibolite leucosomes are trondhjemitic, and formed largely by metamorphic segregation within the stability boundaries of biotite and hornblende. The latter mineral locally breaks down to clinopyroxene+(?)melt, indicating peak anatectic conditions, developed locally, exceeding $800 \mathrm{C}$, still at 5 to $6 \mathrm{~kb}$. However, even where anatexis was locally achieved, plagioclase and quartz controlled partial melt compositions: no potash feldspar was generated by the breakdown of amphibolite hornblende under anatectic conditions. It may be concluded that amphibolites for the most part segregated mobilizate II leucosomes by the process of metamorphic segregation while granitic rocks and paragneisses concomitantly suffered partial melting during migmatization II.

Mobilizate III consists of granitic to trondhjemitic pegmatites and granitoids, clearly of polyphase and allochthonous origin. These appear to have been injected after the culmination of metamorphic conditions, corresponding to migmatization II.

Placed within a regional framework, the clue to the tectonic environment of multiple migmatization seen in the study area lies in the evidence for a major period of extension, corresponding with injection of dyke rocks, followed by regional compression and anatexis. Such a tectonic environment may be represented by back island arc tensional zones, or, perhaps more likely, by crustal doming (extension) followed by compression (plate collision?). Further light will be shed upon this issue as the tectonic significance of the genesis and diapirism of the Grenville anorthosite-mangerite suite is determined. 
VII. FUTURE WORK

A considerable amount of work is required to permit concise definition of the physical-chemical environment and controls of partial melt compositions during migmatization II. Specifically, particular attention should be placed on determining mineral compositions in the paleosome-neosome components of the migmatites. Determination of the relative compositions of key minerals-hornblende, clinopyroxene, plagioclase-provide $s$ a strong indication of which minerals were included in anatectic processes, and the role(s) they played therein. Bulk analyses of leucosomes projected on the $A n-A b-G z-O r-(H 2 O)$ quaternary diagram may further confirm an anatectic origin for mobilizate II leucosomes. Analysis of solid solution minerals, especially cordierite, affords good control on estimates of $\mathrm{PT}(\mathrm{X})$ metamorphic conditions.

It is unlikely that much progress may be made concerning the origin and conditions of formation of mobilizate I leucosomes. Fesolution of this problem should probably proceed by comparison with mobilizate II leucosomes formed in the same paleosomes. Weither is it likely that a better understanding and definition of early tectonic structures (F1 or earlier) is possible, at least within the study area. However, better exposures may occur elsewhere; $G$. Woussen has indicated that early nappe-like folds may be present in the old Gneiss Complex. Analysis of these early folds should focus on deformation features shown by mobilizate I veins, which record and identify the oldest structures in the migmatities.

Finally, in the long run, the goal of this, and other research, should be to deteraine a plausible and preferred origin for the Crenville province. The resolution of this problem may lie both in determining the tectonic setting of the proposed anatectic conditions described in this report, and the relation of this environment to the generation of the plutonic bodies-anorthosite, mangerite, charnockite-typifying the Grenville province. 


\section{ACKNOWLEDGEMENTS}

The helpful direction of Drs. E. Dimroth, G. Woussen, and D. Roy in supervising this study is gratefully acknowledged. Y. Boudreault assisted in thin section preparation, and A. Wawrzkow assisted in the preparation of detailed maps and photographs, and in refractive index work. A. Wawrzkow and B. Tremblay draughted Figure 9, after the detailed map by $M$. Elgner and $C$. Schroeder. P. Brard provided instruction in the use and manipulation of the TEXT program. Field work was conducted while the author was employed as a research assistant to E. Dimroth; finances for the study were made available under the Department of Energy, Mines and Resources Research Agreement 70-4-79. Special thanks are due Dr. H.D. Nathan, for inspiration. 


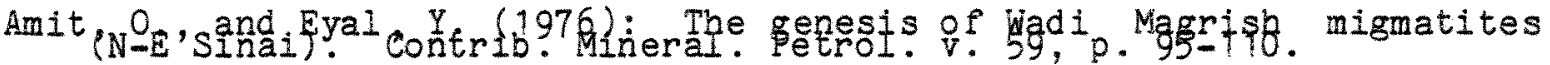
Ashworth, J.R. (1976): Petrogenesis of migmatites in the $661-682$.

Barraud, C. (1977): Evolution tectonique des granulites de la region de Pine Hil1, Sw du complexe anorthositique de Morin, province de Grenville, $P Q$ Canada. PhD thesis, U. Montreal, $207 \mathrm{pp}$. (unpubI).

Berger, A.R., and Pitcher, W.S. (1970): Structures in granitic rocks: Assoc. v. 81 , p. $441-461$.

Brown, G.C., and Fyfe, W.S. (1970): The production of granitic melts during ultrametamorphism. Contrib. Mineral. Petrol. v. 28, p. 310-318.

(1972): The transition from metamorphism to melting: status of the granulite and eclogite facies. 24 th Int. Geol. Congr., v. 2, p. 27-34.

Busch, W., Schneider, G., and Mehnert, K.R. (1974): Initial melting at grain boundaries. Part II. Melting in rocks of granodioritic, uartzdioritic, and tonalitic composition. N. Jb. Miner. Mh. v. 8 . p. $345-370$.

Dallmeyer, R.D., and Dodd, R.T. (1971): Distribution and significance of cordierite in paragneisses of the Hudson Highlands, Southeastern New York. Contrib. Mineral. Petrol. v. 33, p.289-308.

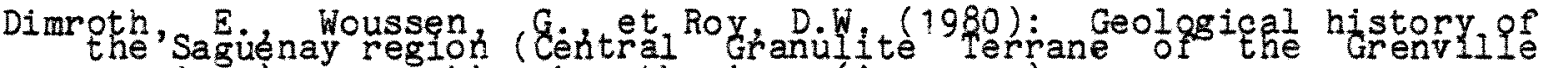
province): a working hypothesis. (in press)

Donath, F.A., and Parker, R.B. (1964): Folds and folding. Geol. Soc. Am. Bull. v. 75, p. 45-62.

Escher, A. (1966): The deformation and granitization of Ketlidian rocks in the Nanortalkik area, S. Greenland. Meddelser om Gronland, Bd. 172 , no. 9 , p. 1-102.

Frith, R.A., and Doig, R. (1973): Rb-Sr isotopic ages and petrologic studies of the rocks in the Lac. St. Jean area, Quebec. Can. J. Earth Science, v. 10, p. $881-899$.

Gagnon, G. (1979): Le complexe de carbonatite de St. Honore et ses depots de Niobium. in: Woussen, G., Gagnon, G., Bonneau, J., Bergeron, A., Dimroth, E., Roy, D.W., and Thiverge, S.: Lithologie et tectonique des roches precambriennes et des carbonatites du Saguenay-Lac St Jean. Guidebook GAC/MAC, Excursion A-3, Laval University, p. 16-29.

Hansen, E. (1971): Strain Facies. Springer-Verlag, N.Y. 207 pp. Hensen, B.J.j and Green, D.H. (1971): Experimental study of the
stability of cordierite and garnet in pelitic compositions at high pressures and temperatures. I. Compositions with excess alumino-silicate. Contrib. Mineral. Petrol.v. 33, p. 309-330.

Henz, R.T. (1976): Phase relations of basalts in their melting ranges at $\mathrm{P}-\mathrm{H} 20 \mathrm{k} \mathrm{kb}$. Part II. Melt compositions. J. Petrology $\mathrm{v}$. 17 , p. $139-193$. 
Holmquist, P.H. (1920): Om pegmatit palingenes ock ptygmatish vecknig. GFF v. 42 , p. 191-213.

Hughes, C.J. (1972): The significance of biotite selvedges in migmatites. Geol. Mag. v. 107, p. 21-24.

Kilinc, R. (1972): Metamorphic differentiation at Einasleigh, Northern Queensiand. J. Geol. Soc. Aust., v. 13, p. 561-582.

Kretz, R. (1966): Shape of mineral grains in metamorphic rocks. J. Petrology. v. 7, p. 68-94.

(1969): On the spatial distribution of crystals in rocks. Iithos v. 2, p. 39-6b.

Martignole, J., and Schrijver, K. (1970a): Tectonic setting and evolution of the Morin anorthosite, Grenville province, Quebec. Buli. Geol. Findlande, v. 42, p. 165-209.

(1970b): The level of anorthosites and its tectonic pattern. Tectonophysics v. 10, p. 403-409. Mennert. K.R. (1968): Migmatites and the Origin of Granitic Rocks.

- Busch, Woundaries of quart schneider $\mathrm{G}$ and (1973): Injtial melting at grain Jb. Miner. Mh. v. 4, p. 165-183.

Misch, P. (1968): Plagioclase compositions and non-anatectic origin of migmatitic gneisses in Northern Cascade Mountains of Washington

- State. Contrib. Mineral. Petrol.v. 17, p. 1-70.

Miyashiro, A. $(1957)$ : Cordierite-indialite relations. Amer. J. Sci.

Molen, I van der, and Paterson, M.S (1979): Experimental deformation of partially melted granite. Contrib. Mineral. Petrol. v. 70, p. 299-318.

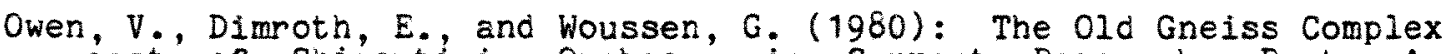
east of Chicoutimi, Quebec. in Current Research, Part A, Geological Survey of Canada, Paper 80-1A, p. 137-146.

Ramberg, H. (1956) Pegmatites in West Greenland. Geol. Soc. Am. BuI1. $v: 67$, p. i85-214.

Read, H.H. (1957): The Granite Controversy. Murby, London. 430 pp.

Scheumann, K.H. (1936): Zur Nomenklatur migmatischer und verwandter Gesteine. Tschem. Miner. Petr. Mit. v. 48, p. 297-302.

Sederholm, J.J. (1907): Om granit och gnejs. Bull. Com. Geol. Findlande. v. 23.

, (1967): Selected works: Granites and Migmatites. Oliver and Bóyd, Edinburgh. o0ठ pp.

Steuhl, H.H. (1962): Die experimentelle Metamorphose und Anatexis eines Parabiotitgneises aus dem Schwarzwald. Chemie de Erde. v. 21 , p. 413-449.

Tobschall, H.J. (1971): Zur Genese der Migmatite des Beaume-Tales (Mittlere Cevennen, Dep. Ardeche). Contrib. Mineral. Petrol.v. $32,93-111$. 


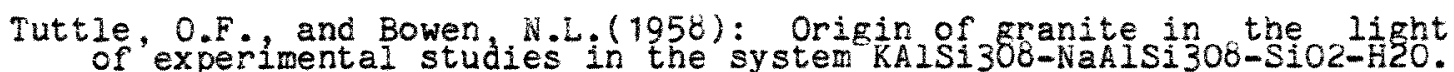
Geol. Soc. Am. Mem. 74,153 pp.

Van der Plas, I. hand Tobi, A.C. (1965): A chart for judging the reliability of point counting results. Amer. J. Sci. v. 263, p. $87-90$.

Vernon, R.H. (1976): Metamorohic Processes. Murby, London. 247 pp. Wegmann, C.E. (1963): Tectonic patterns at different levels. Geol. Soc. S. Africa: Annexure to v. LXVI, $78 \mathrm{p}$.

White, A.J.R. (1966): Genesis of migmatites from the Palmer region of South Australia. Chem. Geol. v. 1, p. 165-200.

Winkler, H.G.Fi (1979): Petrogenesis of Metamorphic Rocks. Springer

Woussen, G., Dimroth, E., Corriveau, L., and Archer, P. (1980): Crystalization and emplacement of the Lac St. Jean anorthosite at Chicoutimi, Quebec. Contrib. Mineral. Petrol. (in press)

Wynne-Edwards, H.R. (1972): The Grenville Province, in: Price, R.A., and Douglas, R.J.W. (eds): Variations in tectonic styles in Canada. Geol. Assoc. Canada Spec. Pap. 11, p. 263-334.

Wyllie, P.J. (1977): Crustal anatexis: an experimental review. Tectonophysics v. 43, p. 41-71.

Yardley, B.W.D. (1975): On some quartz-plagioclase veins in the Connemara Schists, Ireland. Geol. Mag. v. 112, p. 183-190.

(1978): Genesis of Skagit Gneiss migmatites, Washington, and the distinction between possible mechanisms of migmatization. Bull. Geol. Soc. Am. v. 89, p. 941-951. 
APPENDIX 1: Point count results.

Material Section Mineral Count i Where undertaken Add"I Total:

Granite II

Count

\begin{tabular}{|c|c|c|c|}
\hline paleosome & $0 S-11-4$ & $\begin{array}{l}q z \\
\bar{K}-s p \\
\text { plag } \\
\text { opo } \\
\text { opq }\end{array}$ & $\begin{array}{l}176 \\
118 \\
78 \\
11 \\
503\end{array}$ \\
\hline mobilizate & IIa & $\begin{array}{l}q z \\
K-s p \\
\text { plag } \\
\text { bio }\end{array}$ & $\begin{array}{l}263 \\
309 \\
78 \\
\frac{5}{650}\end{array}$ \\
\hline paleosome & $O S-25-F 1 a$ & $\begin{array}{l}q^{2} \\
K_{-s p} \\
\text { plag } \\
\text { hbl }\end{array}$ & $\begin{array}{l}129 \\
160 \\
116 \\
45 \\
450\end{array}$ \\
\hline mobilizate & II & $\begin{array}{l}\mathrm{gz} \\
\mathrm{K}-\mathrm{sp} \\
\mathrm{plag} \\
\mathrm{hbl}\end{array}$ & $\begin{array}{r}143 \\
91 \\
191 \\
25 \\
450\end{array}$ \\
\hline
\end{tabular}

Granite II

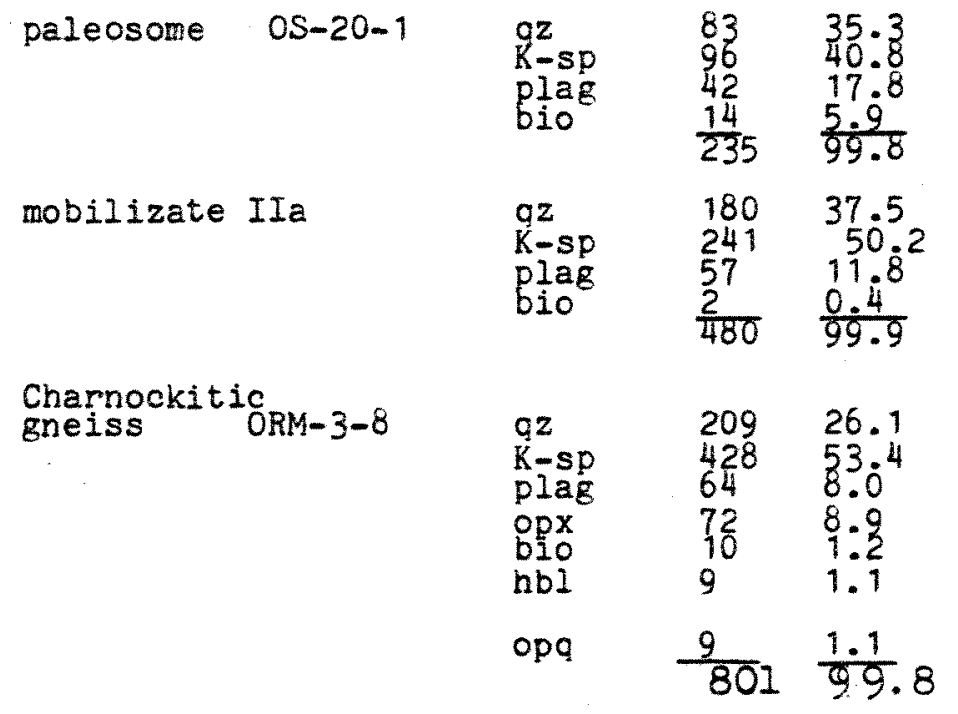


Material

mobilizate IIa

melanosome "a" (Fig. 29)

$\begin{array}{cl}\text { ON-1-1 } & \text { gz } \\ & \text { R-sp } \\ \text { plag } \\ \text { hbl } \\ \text { bio } \\ \text { opq }\end{array}$

gz

K-sp

hbI

$\begin{array}{ll}q z & 377 \\ \text { plag } & 1 \\ \text { mafics: } & \frac{2}{\delta}\end{array}$

melanosome "b" (Fig. 29)

$\mathrm{q} z$

piag

hbl

melanosome mobilizate IIa OS-1-2b

$\frac{4300}{800} \quad 100.0$

Where undertaken Add' 1 Total \%

Count
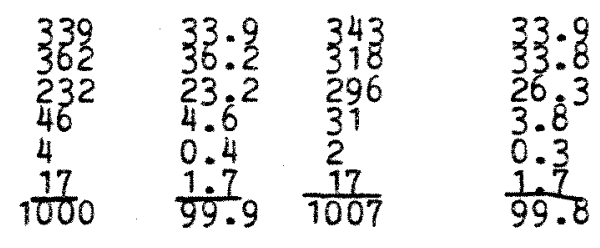

$\begin{array}{lll}239 & 43.4 & 42 \\ 202 & 36.7 & 38 \\ 105 & 19.1 & 19 \\ 4 & 0.7 & \frac{1}{100}\end{array}$

43.2
36.9

19.0

$\frac{0.7}{99.8}$

$\begin{array}{lll}g z & 437 & 40.7 \\ K-s p & 484 & 45.0\end{array}$

$\begin{array}{lll}\text { plag } & 41 & 8.2 \\ \text { hb1 } & 24 & 6.0\end{array}$

$\frac{24}{1074} \quad 9 \frac{6.0}{9.9}$

$\begin{array}{lll}\text { gz } & 308 & 38.4 \\ \text { k-sp } & 49 & 6 . i^{4} \\ \text { plag } & 216 & 26 .{ }^{9} \\ \text { hbi } & 49 & 6 . i^{2} \\ \text { bio } & 126 & 15.7 \\ \text { opq,sph } & \frac{54}{802} & \frac{6.7^{7}}{99.8}\end{array}$


Material Section Mineral Count \& Where undertaken Add Total:

Granite I (cont"d)

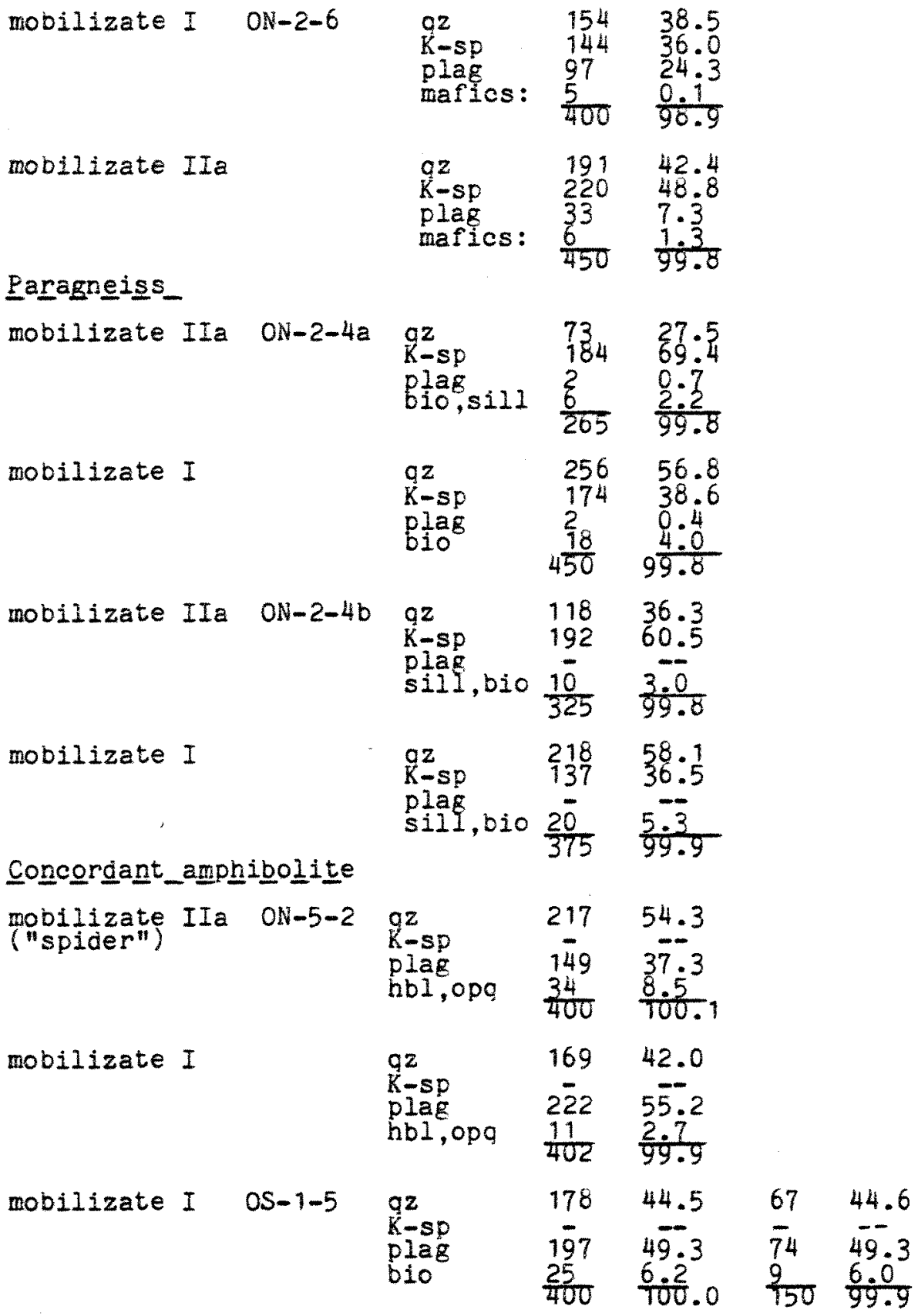


Recrystalization effects of trondhjemitic mobilizate III intruding concordant amphibolite (refer to Table 12 for description of zones)

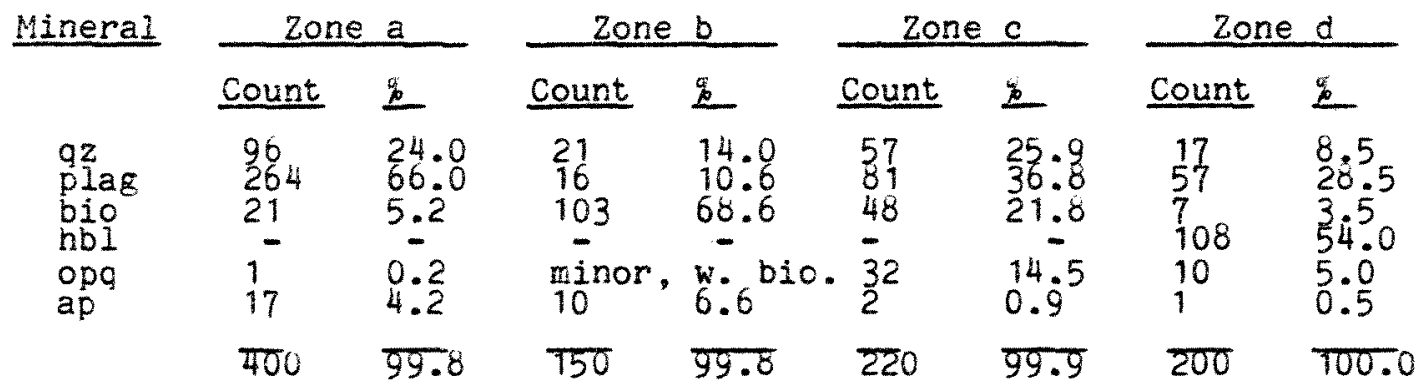

Abbreviations

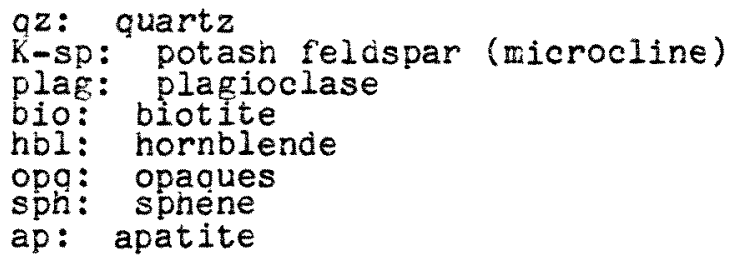

Notes on use and interpretation of point count results

The modal compositions of paleosomes and mobilizates of the old Gneiss Complex were determined to quantify petrographic descriptions outined in the text. As a result of the large number of possible paleosome-mobilizate combinations resulting from polyphase migmatization in the study area, a limited number of thin sections representing each paleosome (and in situ mobilizate) were available for examination. Consequently, the modal compositions Iisted above are representative only of the samples studied. Furthermore. the coarse grain size of different lithologies, particularly granite II and mobilizate II, limited the total count possible per thin section, seriously compromising the statistical validity of the point count results. However, as indicated on the chart provided by Van der plas (1965), it is seen that for major (ie $>40 \%$ mineral consituents, a modal accuracy within a few is may be attained for point counts totaling less than 1000 . Both mobilizate I vein and melanosomes bordering mobilizate II segregations are thin ( 1 to 6 mm), consequently these neosome components are not entirely amenable to the point count method. In particular, melanosomes are seen to grade diffusely into the adjacent paleosome, consequently it is not possible to clearly delineate the melanosome component. Thus, in these cases, point count results are reproducible only if the researcher consistently separates neosome components along the same lines in thin section. Given the scale of melanosomes and mobilizate $I$ veins, this clearly is not possible. 
APPENDIX 2: Cross reference-Plates/file number.

PLATE EILE LISTING

(rol1/shot )

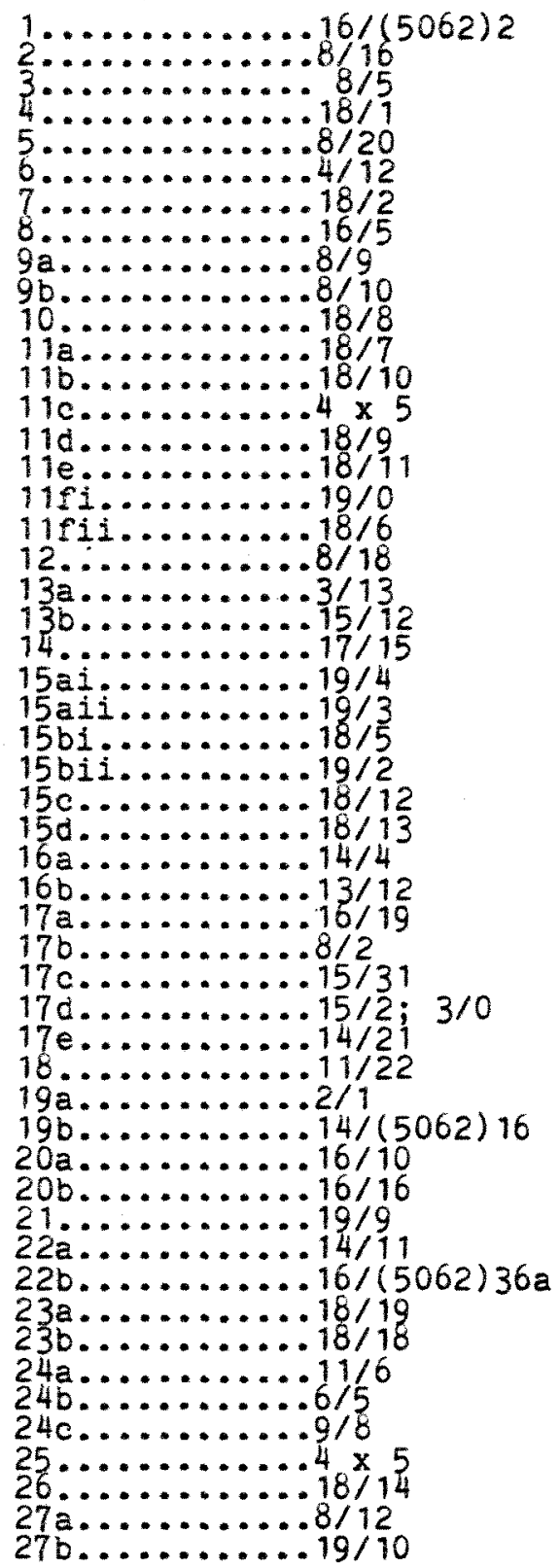

Note: $" 4 \times 5$ " indicates a $4 " \times 5 "$ plate negative. 
APPENDIX 2 (cont' $d$ ): Cross reference-Plates/file number.

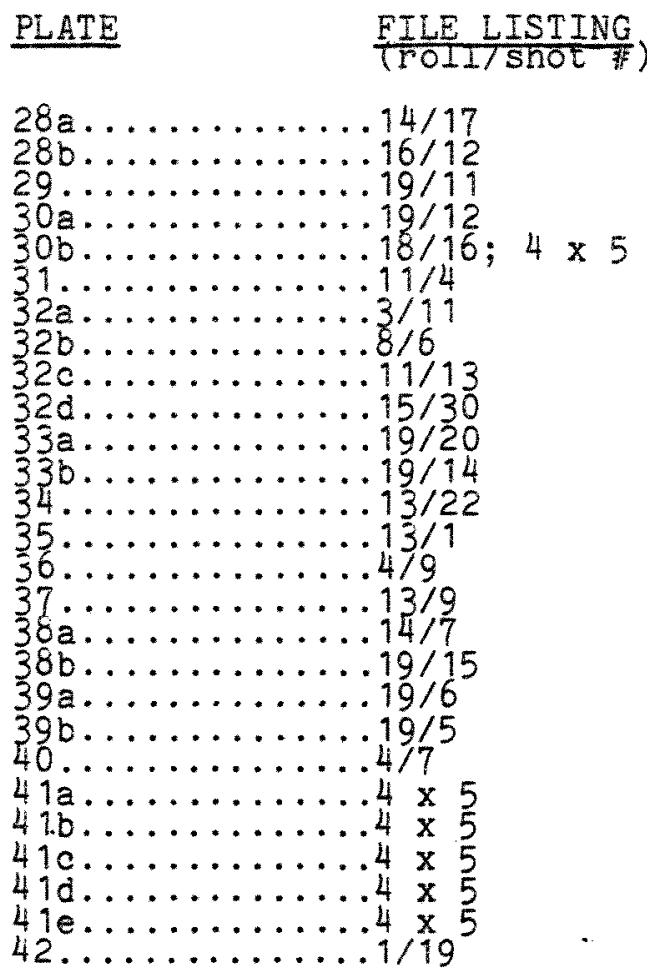

